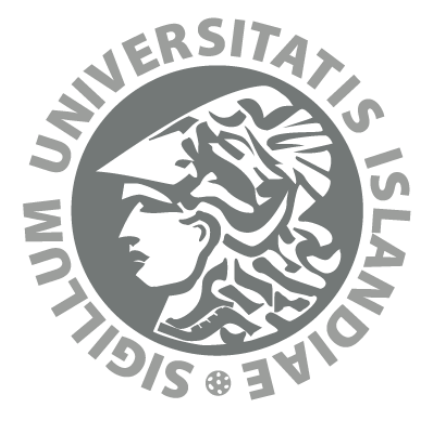

Purine-derived nitroxides for noncovalent spinlabeling of abasic sites in duplex nucleic acids

Nilesh Ramesh Kamble

Faculty of Physical Sciences

School of Engineering and Natural Sciences

University of Iceland

2017 



\title{
Purine-derived nitroxides for noncovalent spin- labeling of abasic sites in duplex nucleic acids
}

\author{
Nilesh Ramesh Kamble \\ Dissertation submitted in partial fulfillment of a \\ Philosophiae Doctor degree in Chemistry \\ Advisor \\ Prof. Snorri Th. Sigurdsson \\ PhD Committee \\ Prof. Guðmundur G. Haraldsson \\ Prof. Már Másson \\ Opponents \\ Dr. Stefán Jonsson \\ Dr. Janet Lovett
}

Faculty of Physical Sciences

School of Engineering and Natural Sciences

University of Iceland

Reykjavik, December 2017 
Purine-derived nitroxides for noncovalent spin-labeling of abasic sites in duplex nucleic acids

Dissertation submitted in partial fulfillment of a Philosophiae Doctor degree in Chemistry

Copyright (C) 2017 Nilesh Ramesh Kamble

All rights reserved

Faculty of Physical Sciences

School of Engineering and Natural Sciences

University of Iceland

Dunhagi 3

107, Reykjavik

Iceland

Telephone: 5254000

Bibliographic information:

Nilesh Ramesh Kamble, 2017, Purine-derived nitroxides for spin-labeling of abasic sites in duplex nucleic acids, Faculty of Physical Sciences, University of Iceland.

Printing: Háskólaprent Ehf.

Reykjavik, Iceland, December 2017 


\section{Abstract}

Electron paramagnetic resonance (EPR) spectroscopy is a well known technique that is routinely used to investigate the structure and dynamics of nucleic acids. EPR requires incorporation of paramagnetic centers at specific sites, called site-directed spin labeling (SDSL). Spin labeling of nucleic acids can be carried out by two approaches, either by forming a covalent bond between spin label and the nucleic acid or by noncovalent binding of the spin label to the nucleic acid. This PhD dissertation is focused on advancing noncovalent and site-directed spin labeling (NC-SDSL) of nucleic acids. Our approach is based on ligand-receptor interactions, where the spin label binds to an abasic site of nucleic acids through formation of Watson-Crick base pairing with an orphan base on the opposing strand and pistacking interaction.

A series of purine-based spin labels were prepared. Both 1,1,3,3tetramethylisoindolin-2-yloxyl and 2,2,6,6-tetramethylpiperidine-1-oxyl (TEMPO) were conjugated with either the C2- or C6-position of the purines, yielding nitroxide derivatives of guanine, adenine or 2,6-diaminopurine. The binding of these spinlabeled purines to abasic sites in duplex nucleic acids was evaluated by EPR spectroscopy. The isoindoline-derived spin labels showed full binding to abasic sites in RNA duplexes and emerged as superior binders when compared to TEMPO-derived spin labels. The guanine-derived Ǵ bound fully to both DNA and RNA duplexes at lower temperature when paired with cytosine (C). Ǵ bound much more efficiently to RNA than DNA and showed even extensive binding at $20{ }^{\circ} \mathrm{C}\left(K_{\mathrm{d}}\right.$ $\left.=6.15 \times 10^{-6} \mathrm{M}\right)$. Adenine-derived spin label 28 was also bound fully at low temperature $\left(-30^{\circ} \mathrm{C}\right)$ to abasic sites in both DNA and RNA duplexes when paired with $\mathrm{T}$ and $\mathrm{U}$, respectively, but showed only minor binding at $20{ }^{\circ} \mathrm{C}(<5 \%)$. Thus, 
Ǵ and 28 allow noncovalent and site directed spin labeling of abasic sites in nucleic acids, using any of the pyrimidines as orphan bases on the opposing strand.

The spin label that bound with the highest efficiency (Ǵ) was chosen to investigate further various aspects of noncovalent spin labeling. Ǵ was found to bind to abasic sites in DNA/RNA hybrids, either to the DNA- or the RNA-strand. Ǵ showed only a minor flanking sequence effect upon binding to abasic sites in RNA, with binding affinities within a factor of two of each other. For a given base on the $5^{\prime}$-end, the highest binding was observed when a $U$ was on the $3^{\prime}$-side. When the abasic site was placed close to the duplex end, the affinity of the spin label was reduced, presumably due to the increased flexibility at base pairs in the vicinity of the duplex terminus. Abasic sites in the fourth position from the duplex end had the same affinity as abasic sites towards the middle of the duplex.

A distance measurement between two spin labels was performed on a Ǵlabeled 22-mer RNA duplex using pulsed electron-electron double resonance (PELDOR) spectroscopy in collaboration with Prof. Thomas Prisner (Goethe University, Germany). The PELDOR data showed a strong orientation dependence and a distance of $31.3 \pm 3.5 \AA$, similar to the distance of $c$ a. $29 \AA$, obtained by molecular modelling.

The noncovalent binding of purine-derived spin labels to the DNA triplex containing one nucleotide gap as binding site in phosphate- as well as magnesium containing-buffer was also evaluated by EPR spectroscopy. The nitroxide connected to N6-position of purine (28-31) had less binding to triplex DNA (IV-VI), whereas Ǵ bound almost fully to the triplex DNA V and VI in magnesium containing buffer. This project was pursued in collaboration with Prof. Clemens Richert's research group at University of Stuttgart, Germany who provided the triplex DNA motifs. 


\section{Útdráttur}

Rafeindaspunalitrófsgreining (e. electron paramagnetic resonance (EPR) spectroscopy) er vel pekkt aðferð sem er reglubundið beitt í rannsóknum á byggingu og hreyfingu kjarnsýra. EPR mælingar krefjast innleiðingar meðseglandi kjarna á ákveðinn stað, p. e. staðbundinnar spunamerkingar (e. site directed spinlabeling, SDSL). Spunamerkingu kjarnsýra má framkvæma á tvo vegu, annarsvegar með samgildum tengjum milli spunamerkis og kjarnsýru og hinsvegar án samgildra tengja. Pessi dokstorsritgerð fjallar um á próun á staðbundnum spunamerkingum án samgildra tengja (e. noncovalent and site-directed spin labeling (NC-SDSL)) fyrir kjarnsýrur. Nálgunin byggist á víxlverkun milli tengils og viðtaka, par sem spunamerkið binst við basalausa stöðu í tvípátta kjarnsýrum með Watson-Crick basapörun við staka basann á mótstæða strendingnum og með pí-stöflun við aðliggjandi basa.

Safn púrín-tengdra spunamerkja var útbúið. Bæði 1,1,3,3tetrametýlísóindólín-2-ýloxýl og 2,2,6,6-tetrametýlpiperidín-1-oxýl (TEMPO) voru tengd við annaðhvort C2- eða C6-stöðuna á púríni, sem gaf nítroxíð afleiður gúaníns, adeníns eða 2,6-díamínópúríns. Binding pessara spunamerktu púrína við basalausa stöðu í tvíspátta kjarnsýrum var mæld með EPR litrófsgreiningu. Afleiður ísóindólín spunamerkjanna bundust að fullu við basalausar stöður í tvípátta RNA og tengdust mun betur en TEMPO afleiðurnar. Gúanín afleiðan Ǵ bast að fullu við bæði tvípátta DNA og RNA við lágt hitastig, pegar hún var pöruð við sýtósín (C). Ǵ bast betur við RNA en DNA og sýndi jafnvel mikla bindingu við $20{ }^{\circ} \mathrm{C}$ $\left(K_{d}=6,15 \cdot 10^{-6} \mathrm{M}\right)$. Adenín spunamerkið 28 sýndi líka fulla bindingu við lágt hitastig $\left(-30{ }^{\circ} \mathrm{C}\right)$ við basalausu stöðuna á tvípátta DNA og RNA á móti T annarsvegar og U hinsvegar, en sýndi litla bindingu við $20^{\circ} \mathrm{C}(<5 \%)$. Ǵ og 28 gera pví mögulegt að 
innleiða spunamerki í basalausrar stöður í tvípátta kjarnsýrum á móti pyrimidínunum C (Ǵ) eða T (28) eða U (28).

Spunamerkið sem bast best (Ǵ) var valið til að rannsaka nánar ýmsa pætti spunamerkingar án samgildra tengja. Í ljós kom að Ǵ bast við basalausar stöður í DNA/RNA blendingum, annaðhvort við DNA- eða RNA strendinginn. Basarnir við hliðina á basalausu stöðunni höfðu aðeins lítil áhrif á bindingu Ǵ við basalausu stöðuna í RNA. Fyrir ákveðinn basa á 5‘-endanum fékkst hæsta bindingin pegar U var 3’-megin. Pegar basalausa staðan var nálægt endandum á tvípátta kjarnsýrunni, minnkaði sækni spunamerkisins, væntanlega vegna aukins hreyfanleika basapara sem eru í nánd við endann. Basalaus staða í fjórðu stöðu frá endanum í tvípátta RNA hafði sömu sækni og basalaus staða við miðju.

Fjarlægðamæling milli tveggja spunamerkja var framkvæmd á Ǵ-merktu tvípátta, 22-basapara RNA með notkun PELDOR (e. pulsed electron-electron double resonance) í samvinnu við Prof. Thomas Prisner (Goethe Háskólinn í Frankfurt, Pýskalandi). PELDOR mælingarnar voru háðar innbyrðis afstöðu (e. orientation dependence) spunamerkjanna og gáfu fjarlægðina 31,3 $\pm 3,5$ Å, í góðu samræmi við fjarlægðina frá líkönum (29 Å). 


\section{Table of Contents}

List of Figures ...................................................................................................... xi

List of Schemes ................................................................................................

List of Original Publications ..................................................................................... Xv

Abbreviations .......................................................................................................

Acknowledgements ......................................................................................................xvii

1 The objective and scope of this PhD thesis .......................................................1

2 Introduction......................................................................................................

2.1 Nucleic acids and their biological importance .........................................

2.2 Structural determination of nucleic acids ................................................

2.3 Electron paramagnetic resonance (EPR) spectroscopy ……………........

2.4 Site-directed spin-labeling (SDSL) of nucleic acids ..............................10

2.4.1 The phosphoramidite approach for SDSL .....................................10

2.4.2 The post-synthetic approach for SDSL ..........................................12

2.4.3 Noncovalent and site-directed spin labeling (NC-SDSL) of nucleic acids ..............................................................................15

3 Purine-derived nitroxides for noncovalent spin-labeling of nucleic acids

3.1 Synthesis of purine-derived nitroxide spin labels.....................................20

3.2 Binding of purine-derived spin labels to abasic sites in duplex nucleic acids monitored by EPR spectroscopy ………………..........................23

3.2.1 Binding affinity of spin labels to abasic sites of duplex DNA ......23

3.2.2 Binding affinity of spin labels to abasic sites of duplex RNA ......26

3.2.2.1 Determination of dissociation constants $\left(K_{\mathrm{d}}\right) \ldots \ldots \ldots \ldots \ldots \ldots \ldots \ldots \ldots \ldots \ldots . . . .28$

3.2.2.2 Specificity of binding of Ǵ to abasic sites in RNA duplex .........29

3.2.3 Binding affinity of Ǵ to DNA-RNA hybrids....................................32

3.3 Effect of structural changes in RNA duplexes on Ǵ-binding ...................33

3.3.1 Effect of the location of the abasic site relative to the duplex

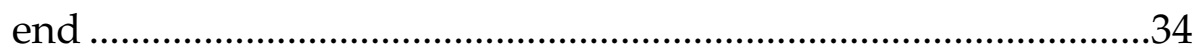

3.3.2 Effect of flanking sequence on binding of Ǵ....................................35

3.4 Distance measurements of Ǵ-labeled RNA duplexes by pulsed EPR

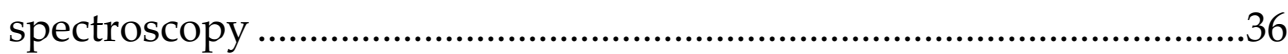


3.4.1 Distance measurement on a 22-mer RNA duplex ..........................38

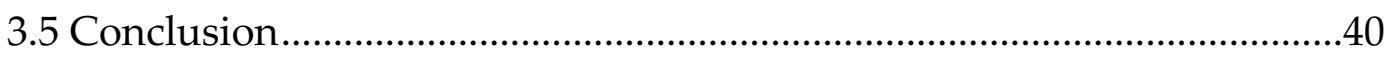

4 Binding of purine-derived spin labels to triplex-based DNA motifs......43

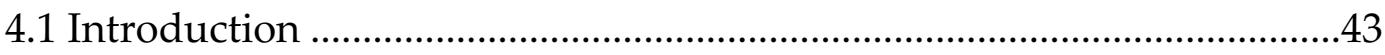

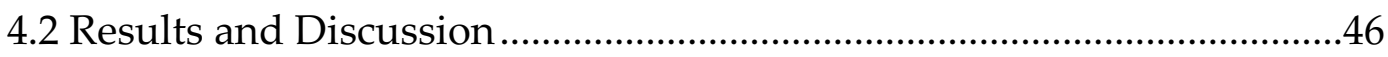

4.2.1 Binding of purine-derived spin labels to triplex-DNA..................46

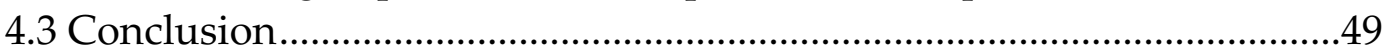

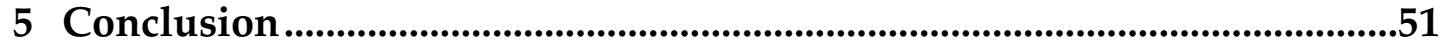

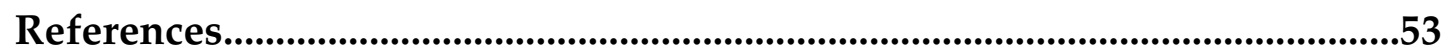

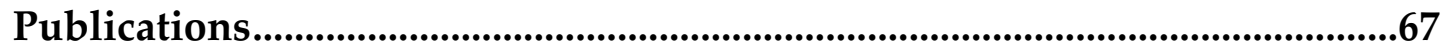




\section{List of Figures}

Figure 1.1 Structures of purine-derived nitroxide spin labels. ........................1

Figure 2.1 (A) Structure of TEMPO ((2,2,6,6-Tetramethylpiperidin-1-yl)oxyl) radical (B) CW-EPR spectrum of TEMPO radical. (C) Structure of chlorpromazine radical cation...........................................................9

Figure 2.2 A nucleoside phosphoramidite building block for a synthesis of RNA oligonucleotides

Figure 2.3 Examples of spin-labeled nucleotide that have been incorporated into nucleic acids by the phosphoramidite method........................12

Figure 2.4 Examples of spin-labeled oligonucleotides that have been prepared by post-synthetic labeling .................................................................14

Figure 2.5 Structures of spin-labeled intercalators which bind to DNA

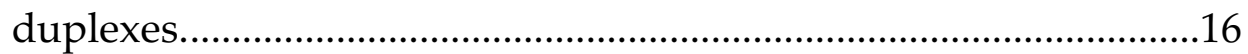

Figure 2.6 Structures of ligands used for noncovalent attachment of nucleic acids.

Figure 2.7 Base-pairing structure of the rigid spin label ç with guanine (G) (left) and a triazole linked- nitroxide spin label 27.

Figure 3.1 Structures of purine-derived nitroxide spin labels.

Figure 3.2 (A) Base-pairing of spin label Ǵ with C, spin label directing into the major groove. (B) Base pairing of spin label 28 with $U / T$, spin label directing into the minor groove.

Figure 3.3 Binding of spin labels to abasic sites of DNA duplexes. EPR spectra of spin labels are shown on the far left and EPR spectra of the labels in the presence of an unmodified DNA on the far right .25

Figure 3.4 EPR spectra of binding of spin labels to an abasic site containing a DNA duplex at different temperatures 
Figure 3.5 Binding of spin labels to abasic sites of RNA duplexes. EPR spectra of spin labels in the presence of an unmodified RNA on the far right

Figure 3.6 EPR spectra of binding of spin labels to an abasic site containing a RNA duplex at different temperatures 28

Figure 3.7 (A) EPR spectra for a titration of Ǵ to an RNA duplex (200 $\mu \mathrm{M})$ containing an abasic site opposite $\mathrm{C}$, using 0.5 eq. (left), 1.0 eq. (middle) and 2 eq. (right) of the spin label at $-20^{\circ} \mathrm{C}$. (B) EPR spectra of $\mathbf{G}(200 \mu \mathrm{M})$ in the presence of an unmodified RNA $(200 \mu \mathrm{M})$ duplex .29

Figure 3.8 CW-EPR spectra of Ǵ $(200 \mu \mathrm{M})$ in the presence of a duplex RNA $(200 \mu \mathrm{M})$ containing an abasic site $\left(_{(}\right)$, along with increasing concentration of hypoxanthine (I) (0-10 equiv.) .30

Figure 3.9 CW-EPR spectra of Ǵ $(200 \mu \mathrm{M})$ in the presence of a duplex RNA $(200 \mu \mathrm{M})$ containing an abasic site $\left(\_\right)$, along with increasing concentration of 50 (0-2 eq.) 31

Figure 3.10 Binding of spin label Ǵ to abasic site of DNA-RNA hybrid duplexes. The DNA-RNA duplex contained an abasic site in DNA strand (first row), whereas RNA-DNA duplex contained an abasic site in RNA strand (second row) and the abasic site denoted by "_"

Figure 3.11 A plot of the dissociation constant $\left(K_{d}\right)$ of Ǵ-binding to RNA-RNA, DNA-RNA and DNA-RNA duplexes containing an abasic site opposite cytosine $(\mathrm{C})$ at $0{ }^{\circ} \mathrm{C}$ 33

Figure 3.12 Binding of Ǵ $(200 \mu \mathrm{M})$ to RNA $(400 \mu \mathrm{M})$ duplexes (III-VI) containing abasic sites (denoted by "-"), where the location of abasic site is moving from $5^{\prime}$-end to the centre of duplex 34

Figure 3.13 EPR spectra of binding of Ǵ $(200 \mu \mathrm{M})$ to duplex RNAs $(400 \mu \mathrm{M})$ containing different flanked bases to the abasic site " _". 35

Figure 3.14 A plot of the dissociation constant of Ǵ-binding to duplex RNA containing an abasic site (denoted by "_") as a function of flanking sequence at $20^{\circ} \mathrm{C}$. 36

Figure 3.15 (A) Solid state EPR spectrum of a nitroxide radical. (B) Pulse sequence for a four-pulse PELDOR. A and B are the two spins 
separated by distance and $\nu_{\mathrm{A}}$ and $\nu_{\mathrm{B}}$ are detection and inversion frequencies respectively, $\mathrm{T}$ denotes the time position for the inversion pulse and $\Delta$ refers to modulation depth. (C) PELDOR time traces of a dipolar coupling. Distance obtained from the two spins A and B. (Figure courtesy: PhD thesis, Nitin Chhaban Kunjir, University of Iceland, 2014)

Figure 3.16 EPR spectra of Ǵ $(400 \mu \mathrm{M})$ in the presence of a 22-mer RNA duplex $(200 \mu \mathrm{M})$ containing two abasic sites, denoted as "_". EPR spectra were recorded in a phosphate buffer $\left(10 \mathrm{mM} \mathrm{Na}_{2} \mathrm{HPO}_{4}, 100 \mathrm{mM}\right.$ $\mathrm{NaCl}, 0.1 \mathrm{mM} \mathrm{Na}$ EDTA, pH 7.0) containing 30\% ethylene glycol and and $2 \%$ DMSO .38

Figure 3.17 (A) Multi-frequency X-band (9.4 GHz) PELDOR experiments after background correction performed at $50 \mathrm{~K}$. The lowest solid trace shows the sum of all the offset measurements, while the dotted trace shows the fit obtained with Tikhonov regularization. Traces have been shifted vertically for better visibility of individual traces. (B) The distance distribution of the summed PELDOR time traces, obtained with DeerAnalysis2013. (C) A model of two G's bound to the two abasic sites of the 22-mer RNA duplex. .39

Figure 3.18 Molecular models of the noncovalently spin-labeled 22-mer RNA duplex in a space-filling representation showing relative position of the two Ǵs (red). The oxygen atoms of the nitroxide functional groups are shown in green.

Figure 4.1 Basic structures of an oligonucleotide-based triple helix interactions

Figure 4.2 Structure of dAMP and cAMP (left). Four-strand based DNA triplex with a single-nucleotide gap (VII), two nucleotide gaps (VIII) and seven-nucleotide gaps (IX) (right).

Figure 4.3 (A) Structures of the purine-derived nitroxide spin labels. (B) Structures of the DNA motifs.

Figure 4.4 EPR spectra of spin labels Ǵ and 28-32 in the presence of DNA motifs $\mathbf{X}, \mathbf{X I}$ and $\mathbf{X I I}$. 


\section{List of Schemes}

Scheme 3.1 (A) Synthesis of purine-derived isoindoline nitroxide 28. (B) Synthesis of purine-derived TEMPO radical 29

Scheme 3.2 Synthesis of isoindoline-derived 2,6-diamino purine 30 and TEMPO-derived 2,6-diamino purine 31 ............................................21

Scheme 3.3 Synthesis of guanine-derived isoindoline nitroxide spin label Ǵ

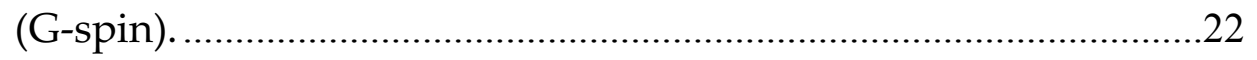

Scheme 3.4 Synthesis of guanine-derived TEMPO nitroxide spin label $32 \ldots . .23$

Scheme 3.5 Synthesis of compound 50 . .31 


\section{List of Original Publications}

List of publications that are a part of this doctoral thesis

I. Nilesh R. Kamble, Markus Gränz, Thomas F. Prisner and Snorri Th. Sigurdsson; "Non-covalent site-directed spin labeling of duplex RNA", Chem. Commun., 2016, 52, 14442-14445.

II. Nilesh R. Kamble, Snorri Th. Sigurdsson; "Purine-derived nitroxides for noncovalent spin-labeling of abasic sites in duplex nucleic acids", Chem. - Eur. J., 2017, Just Accepted.

List of publication that is not a part of this doctoral thesis

III. Margret Thorsteinsdottir, Unnur A. Thorsteinsdottir, Finnur F. Eiriksson, Hrafnhildur L. Runolfsdottir, Inger M.Sch. Agustsdottir, Steinunn Oddsdottir, Baldur B. Sigurdsson, Hordur K. Hardarson, Nilesh R. Kamble, Snorri Th. Sigurdsson, Vidar O. Edvardsson, Runolfur Palsson; "Quantitative UPLC-MS/MS assay of urinary 2,8-dihydroxyadeine for diagnosis and management of adenine phosphoribosyltransferase deficiency", J. Chromatogr. B., 2016, 1036-1037, 170-177. 


\section{Abbreviations}

\begin{tabular}{|c|c|}
\hline A & adenine \\
\hline $\mathrm{C}$ & cytosine \\
\hline cAMP & cyclic adenosine monophosphate \\
\hline CD & circular dichroism \\
\hline CW & continuous wave \\
\hline DCE & dichloroethane \\
\hline DEER & double electron-electron resonance \\
\hline DFT & density functional theory \\
\hline DMAP & dimethyl amino pyridine \\
\hline $\mathrm{DMF}$ & $N, N$-dimethylformamide \\
\hline DMSO & dimethylsulfoxide \\
\hline DNA & deoxyribonucleic acid \\
\hline EPR & electron paramagnetic resonance \\
\hline ESR & electron spin resonance \\
\hline FMN & flavin mononucleotide \\
\hline FRET & fluorescence resonance energy transfer \\
\hline G & guanine \\
\hline Ǵ & G-spin \\
\hline$K_{d}$ & dissociation constant \\
\hline mRNA & messenger ribonucleic acid \\
\hline miRNA & micro ribonucleic acid \\
\hline siRNA & small interfering RNAs \\
\hline NC-SDSL & noncovalent site-directed spin labeling \\
\hline NMR & nuclear magnetic resonance \\
\hline PELDOR & pulsed electron-electron double resonance \\
\hline RNaseH & Ribonuclease H \\
\hline rRNA & ribosomal RNA \\
\hline SDSL & site-directed spin labeling \\
\hline SELEX & systematic evolution of ligands by exponential enrichment \\
\hline snRNAs & small nuclear RNAs \\
\hline $\mathrm{T}$ & thymine \\
\hline tRNA & transfer RNA \\
\hline TEMPO & 2,2,6,6-tetramethylpiperidine-1-oxyl \\
\hline TFO & triplex-forming oligonucleotide \\
\hline TPA & 2,2,5,5-tetramethyl-pyrrolin-1-yloxy-3-acetylene \\
\hline $\mathrm{U}$ & uridine \\
\hline
\end{tabular}




\section{Acknowledgements}

First of all, I would like to express my deep sense of thanks and gratitude to my PhD supervisor Prof. Snorri Thor Sigurdsson for his guidance, encouragements and help to achieve my goals during my PhD. His immense scientific knowledge, enthusiasm and motivation helped strongly to develop my scientific skill. I will remain forever thankful for his support in professional and personal levels.

Besides my advisor, I would like to thank my doctoral committee members Prof. Guðmundur G. Haraldsson and Prof. Már Másson, for their encouragement, support and insightful comments about my research work. I would also like to thank Prof. Guðmundur G. Haraldsson for examining my organic chemistry courses and helping me to strengthen my knowledge. I also thank my collaborators Prof. Thomas Prisner, Prof. Clemens Richert, Dr. Markus Gränz and Nicole Erlenbach for their efforts and support in our collaborative research work. I also thank my present and past members of my research group, Dr. Sandeep Shelke, Dr. Marco Körner, Dr. Nitin Kunjir, Dr. Dnyaneshwar Gophane, Dr. Anil Jagtap, Dr. Subham Saha, Snaedis Björgvinsdóttir, Haraldur Y. Júlíusson, Sucharita Mandal and Anna-Lena Segler for their support and friendship. I am especially thankful to Dr. Subham Saha for reading my thesis and manuscript critically. I thank Dr. Sigridur Jónsdóttir for assistance in collecting analytical data.

I also would like to thank the University of Iceland Research Fund for providing the doctoral research fellowship and my doctoral advisor Prof. Snorri Thor Sigurdsson for financial assistance.

My sincere thanks to my former mentors Prof. Arun Natu, Dr. Sanjeev Kulkarni, Prof. Milind Nikalje and Dr. Anil Gajare for their guidance and support.

I would like to thank my parents and family for their support and encouragement. Especially, my wife Bhakti and my son Mayank for their patience, love and support. 
Dedicated to my wife Bhakti, my son Mayank and my parents 



\section{The objective and scope of this PhD thesis}

The objective of this thesis is to further explore and expand the scope of noncovalent and site-directed spin labeling (NC-SDSL) of nucleic acids using purine-derived nitroxide spin labels. NC-SDSL could give easy access to spin-labeled nucleic acids to study their structure and dynamics by electron paramagnetic resonance (EPR) spectroscopic methods. The spin labels bind to the abasic site of duplex nucleic acids by forming Watson-Crick base pairs to an orphan base on the opposing strand and pi-stacking interactions with the flanked bases. For this purpose, a series of purinederived spin labels (Figure 1.1) were prepared, that contain nitroxides in either the C2- or the C6- position, affording adenine-, guanine- or 2,6-diaminopurine-derived spin labels. The binding-affinity and -specificity of these spin labels to the abasic site of duplex nucleic acids were determined by EPR spectroscopy.

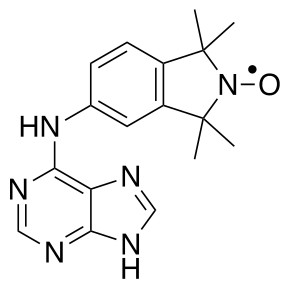

28<smiles>CC1(C)CC(Nc2nc(N)nc3[nH]cnc23)CC(C)(C)N1O</smiles>

31

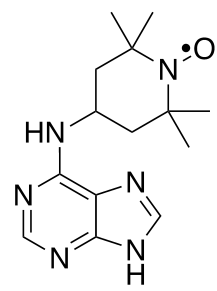

29

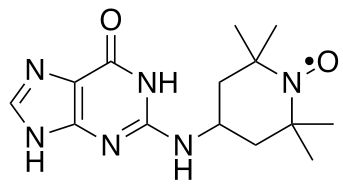

32

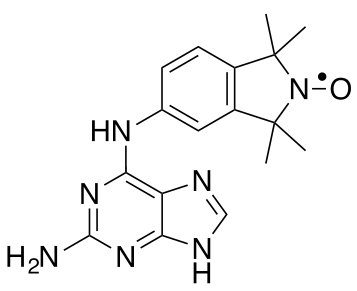

30<smiles>CC1(C)c2ccc(Nc3nc4[nH]cnc4c(=O)[nH]3)cc2C(C)(C)N1[O-]</smiles>

Ǵ

Figure 1.1 Structures of purine-derived nitroxide spin labels. 
A brief introduction of nucleic acids and their biological importance is described in chapter 2. The important spectroscopic techniques that has been used for structural determination of nucleic acids is also described. The use of EPR spectroscopy for determination of structure and dynamic of nucleic acids by sitedirected spin labeling (SDSL) is highlighted. The methods that have been used for spin-labeling of nucleic acids is briefly outlined with their merits and demerits. As noncovalent spin-labeling is the method of focus in this thesis, its detailed historical background is also described in chapter 2.

The synthesis of purine-derived nitroxide spin labels and their binding affinities to the abasic site of duplex nucleic acids that were determined by EPR spectroscopy is described in Chapter 3 . The adenine derivative 28 and the guaninenitroxide conjugate Ǵ (G-spin) bound almost fully to an abasic site of DNA duplexes and bound completely to RNA duplexes. Ǵ bound extensively even at $20{ }^{\circ} \mathrm{C}$ to the abasic site of RNA duplex. I also highlight the experiments addressing the binding specificity and selectivity of $\mathbf{G}$ to the abasic site of an RNA duplex. Competition experiments with hypoxanthine or reduced-Ǵ (50) were performed to displace the binding of Ǵ. Both hypoxanthine and $\mathbf{5 0}$ can displace Ǵ from the abasic site, with hypoxanthine being less efficient than 50. Also, the first example of noncovalent spin-labeling to DNA-RNA hybrids is described, where Ǵ bound fully to DNARNA hybrids that contain an abasic site. A detailed study of influence of binding of Ǵ with the structural changes, like change in the location of abasic site in RNA duplexes and the effect of flanking bases immediate to the abasic site is also described in this chapter. The last section describes the application of NC-SDSL of duplex RNA for distance measurements between the two noncovalently attached Ǵs by a pulsed electron-electron double resonance (PELDOR) spectroscopy. This work was carried out in collaboration with Prof. Thomas Prisner's laboratory at the Goethe University of Frankfurt, Germany. Ǵ bound fully to both abasic sites of the RNA duplex allowing distances measurements between the two spin centers. 
Orientation effects were observed in the PELDOR experiments, indicating limited mobility of the spin label when bound to the nucleic acid.

Chapter 4 describes the triplex-DNA motifs and the formation of triple-helical structures. Noncovalent binding of the purine-derived spin labels to DNA triplexes containing a one nucleotide gap as a binding site was evaluated in phosphate- as well as magnesium-containing buffer. Only Ǵ was shown to bind almost fully to the triplex DNA XI and XII. This project was pursued in collaboration with Prof. Clemens Richert's research group at University of Stuttgart, Germany, who provided the triplex DNA motifs. 


\section{Introduction}

\subsection{Nucleic acids and their biological importance}

In 1869, young Swiss physician Friedrich Miescher isolated an unknown phosphaterich substance from pus cells, which he named "nuclein". ${ }^{[1]}$ Later he found that nuclein had acidic properties and hence introduced the term nucleic acid to replace nuclein. ${ }^{[1-3]}$ The presence of purine and pyrimidine bases was discovered in $1880 \mathrm{~s}$ by H. E. Fischer. ${ }^{[4]}$ In 1910, the Russian-born biochemist P.A. Levene recognized the 5-carbon ribose sugar in nucleic acids, ${ }^{[5]}$ called deoxyribonucleic acid (DNA) and ribonucleic acid (RNA). ${ }^{[6]}$ The most path-breaking scientific discovery was done by James Watson and Francis Crick, who discovered the helical structure of DNA in 1953. ${ }^{[7]}$ The helical structure was made by two spiral DNA strands, each containing a long chain of monomer nucleotides, wound around each other by forming Watson-Crick base-pairs.

DNA is organized into chromosomes and contains genetic information for the cell activities and RNAs are essential in the synthesis of proteins. The information contained within the genetic code is passed from DNA to messenger ribonucleic acid (mRNA) to resulting proteins with specific amino acid sequences by a ribosome. ${ }^{[8]}$ In the process of carrying the genetic information from DNA to the ribosome, RNA plays many essential roles, including amino acid transfer, regulation of gene expression and protein synthesis. ${ }^{[9-11]}$ mRNA, transfer RNA (tRNA), and ribosomal RNA (rRNA) are three different types of RNA that take part in the translation process and each type is involved in different functions and activities. Messenger RNA carries genetic sequence information between DNA and ribosomes for the synthesis of proteins. ${ }^{[8]}$ Transfer RNA binds to both mRNA and 
amino acids and brings the correct amino acids into the growing polypeptide chain at the ribosomal site of protein synthesis during translation.

A number of other biologically-active RNAs have been found that have different functions. For example, small nuclear RNAs (snRNAs) play a critical role in gene regulation by way of RNA splicing. ${ }^{[12,13]}$ RNA splicing is a process in which introns are removed and exons are joined, which is performed by the spliceosome. Some RNAs catalyze reactions, similar to enzymes known as ribozymes, for example, peptide-bond formation is catalyzed by the ribosome during protein synthesis. ${ }^{[14]}$ Moreover, in certain cases mRNA has been known to be responsible for controlling gene expression. ${ }^{[15]}$ These naturally occurring mRNAs, called riboswitches, have been found to bind to a variety of metabolites that results in alteration of the gene's activity. ${ }^{[16-18]}$

Small interfering RNAs (siRNA) are yet another class of RNAs consisting of 21-25 base pairs in length. ${ }^{[19]}$ The most notable role of siRNA in the RNA interference (RNAi) pathway, is to inhibit gene expression. In 1999, David Baulcombe's group discovered siRNA and their role in post-transcriptional gene silencing in plants. ${ }^{[20]}$ Thomas Tuschl et.al synthesized a 21 nucleotide siRNA and induced into mammalian cells. ${ }^{[21]}$ Micro RNAs (miRNA) are also involved in inhibition of gene expression, which is a small single-stranded RNA (ca. 22 nucleotides) found within the introns of large RNA molecules. Both siRNAs and miRNAs in short duplex molecules bring a gene silencing effect at the post-transcriptional level by targeting mRNA. Recently, siRNAs and miRNAs have been investigated as novel therapeutic agents for the treatment of wide range of disorders including cancer and infections. [22-25] 


\subsection{Structural determination of nucleic acids}

It is well known that nucleic acids are involved in the processes of cell division and growth, and that they participate in the transmission of hereditary characters and are important elements of viruses. Therefore, it has become important to understand the molecular structure and dynamics of the nucleic acids to understand their biological functions. There are several biochemical and biophysical techniques that have been developed in the last few decades to obtain their structural information. These techniques are classified into two groups, namely high- and low-resolution techniques. X-ray crystallography is an example of high-resolution technique that can give three-dimensional structural information of biomolecules with precise arrangements of atoms in space. ${ }^{[26]}$ Some X-ray crystal structures of ribosomes ${ }^{[27,28]}$ and riboswitches ${ }^{[29]}$ have been reported showing three-dimensional arrangements of atoms or groups. Although this technique is most informative, there are some limitations, such as it requires a relatively large amount of sample and can be a time consuming task to get a single crystal of nucleic acids that diffracts well. Furthermore, the obtained crystal structures may not be in the active conformation. Therefore, scientists are also using spectroscopic techniques to obtain threedimensional structural information of nucleic acids.

Nuclear magnetic resonance (NMR) spectroscopy is a very useful technique to obtain high resolution structural information of biomolecules under biologicallyrelevant conditions. ${ }^{[30-34]}$ NMR spectroscopy has made it possible to study complex processes such as metabolic-riboswitch binding, ${ }^{[35]}$ protein-DNA binding interactions, ${ }^{[36]}$ identification of noncanonical RNA structures ${ }^{[37]}$ and RNA metal-ion binding. ${ }^{[38]}$ Site specific attachment of ${ }^{19} \mathrm{~F}$ isotope-labeled nucleic acids has been used to analyze structure and conformations via changes in chemical shifts. ${ }^{[39-42]}$ However, NMR spectroscopy has some restrictions. For example, it requires sample in milligram quantities, which is a considerably large amount compared to biomolecules. Furthermore, the synthesis of isotopically-labeled nucleic acid can be 
tedious and expensive. ${ }^{[43]}$ Another major limitation is that the size of nucleic acids can not exceed $50 \mathrm{kDa},{ }^{[44]}$ which results in slow tumbling of molecule on NMR time scale which in turn causes broadening of the peaks.

Fluorescence resonance energy transfer (FRET) spectroscopy is a technique that gives a way to measure distances in the 10-100 $\AA$ range, ${ }^{[45-49]}$ and has been extensively used to study tertiary structures of nucleic acids, providing information about their global shape. ${ }^{[50]}$ FRET requires small amounts of sample and the studies can be carried out under biologically-relevant conditions. Single molecule fluorescence resonance energy transfer (smFRET) is a technique which has been used to study structures, dynamics and mechanism of biomolecular systems. Using this technique a wide range of biological questions are now addressed like mechanisms of molecular machines, ${ }^{[51,52]}$ protein-nucleic acid interactions, ${ }^{[51]}$ enzymatic reactions, ${ }^{[51]}$ and protein or RNA folding. ${ }^{[51]}$ In addition, there are several other low-resolution techniques that are useful for studying nucleic acids, such as non-denaturing gel electrophoresis, ${ }^{[53]}$ circular dichroism (CD) spectroscopy, ${ }^{[54]}$ Raman spectroscopy ${ }^{[55]}$ etc. which can provide information about the global shape of the nucleic acids.

Electron paramagnetic resonance (EPR) spectroscopy is another valuable spectroscopic technique for examination of structure and dynamics of nucleic acids and will be described in the following section. This thesis is mainly focused on EPR spectroscopic techniques that provides structural information of nucleic acids.

\subsection{Electron paramagnetic resonance (EPR) spectroscopy}

Electron spin resonance (ESR) spectroscopy is another name for EPR spectroscopy, which was first invented in 1945 by the Russian physicist Zavoisky. ${ }^{[56]}$ EPR detects electron spins by monitoring transitions in the energy states induced by electromagnetic radiation in an applied magnetic field. Therefore, EPR is useful to study paramagnetic species, like free radicals and certain transition metal ions. Most 
free radicals are short-lived, but they play important roles in reactions like catalytic reactions, oxidation reactions, polymerization and biological reactions like photosynthesis. ${ }^{[57-60]}$ Therefore, EPR spectroscopy is a useful technique for various scientific areas including physics, chemistry, biology, material and medical science.

Continuous wave EPR (CW-EPR) spectroscopy provides precise information about the structure and dynamics of specific site of a biomolecule. ${ }^{[61-66]}$ It can be used for distance measurements in the range of 5-20 $\AA$, based on analysis of peak broadening due to dipolar coupling between two spin centers. ${ }^{[67-69]}$ Pulsed electronelectron double resonance (PELDOR) spectroscopy, also called double electronelectron resonance (DEER) is used to measure long range distances between 20-100 $\AA .{ }^{[70-75]}$ The detail of PELDOR has been included in chapter 3 of this doctoral thesis.

Stable nitroxide radicals are commonly used for EPR spectroscopy applications. ${ }^{[76-79]}$ For example, the piperidine-based 2,2,6,6-tetramethylpiperidine1-oxyl (TEMPO) radical (Figure 2.1A) is widely used for EPR-based investigations. ${ }^{[78,80,81]}$ The unpaired electron on the nitroxide is delocalized between the oxygen and nitrogen atom and electron donating steric protection of neighboring methyl groups stabilize these kind of radicals. ${ }^{[82]}$ The EPR spectrum of a nitroxide (Figure 2.1B) exhibits three lines, due to hyperfine coupling of the electron spin $(S=1 / 2)$ with the nuclear spin $(I=1)$ of nitrogen $\left({ }^{14} \mathrm{~N}\right)$.

A

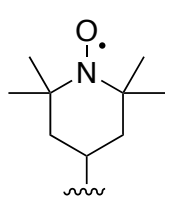

B

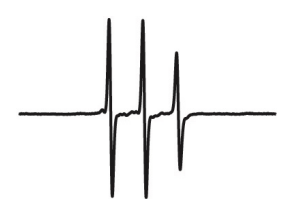

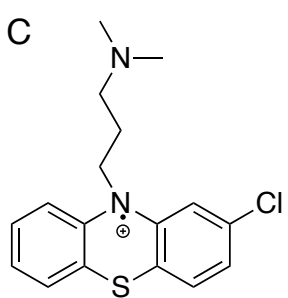

Figure 2.1. (A) Structure of TEMPO ((2,2,6,6-Tetramethylpiperidin-1-yl)oxyl) radical (B) CW-EPR spectrum of TEMPO radical. (C) Structure of chlorpromazine radical cation. 
In 1965, McConnell and co-workers used EPR spectroscopy for the first time to study nucleic acids, specifically investigating the intercalative binding of a chlorpromazine radical cation (Figure 2.1 C) to DNA. ${ }^{[83]}$ There are also some examples of paramagnetic metal ions that are used as spin probes; such as Mn (II) which has been used to study important metal-ion binding sites in the hammerhead ribozyme. ${ }^{84,85]}$ However, the most common strategy for incorporation of spin probe is via covalent attachments of nitroxide radicals. ${ }^{[58,79,86,87]}$

\subsection{Site-directed spin-labeling (SDSL) of nucleic acids}

The site-specific incorporation of a spin label to the nucleic acids is known as sitedirected spin-labeling (SDSL) of nucleic acids. ${ }^{[62,63,78,80]}$ In SDSL, the spin label can be incorporated into nucleic acids either covalently or noncovalently. There are two methods that have been used for covalent attachment of spin labels. The first method involves spin-labeled phosphoramidites that are incorporated at specific position during automated chemical synthesis of nucleic acids. The second method is called post-synthetic labeling, in which reactive functional groups in specific sites of nucleic acids can be used for attachment of spin labels. These two techniques will be described in more detail below, before addressing the main topic of this thesis noncovalent spin labeling.

\subsubsection{The phosphoramidite approach for SDSL}

In 1980, Marvin Caruthers developed the phosphoramidite method, ${ }^{[88]}$ which greatly enhanced the application of solid-phase synthesis of nucleic acids and its automation. Nucleoside phosphoramidites are key building blocks that are used for solid-phase synthesis of oligonucleotides (Figure 2.2). Due to the straight-forward automated synthesis of oligonucleotide, modifications in nucleic acids can be easily performed by synthesizing modified phosphoramidite building blocks. 

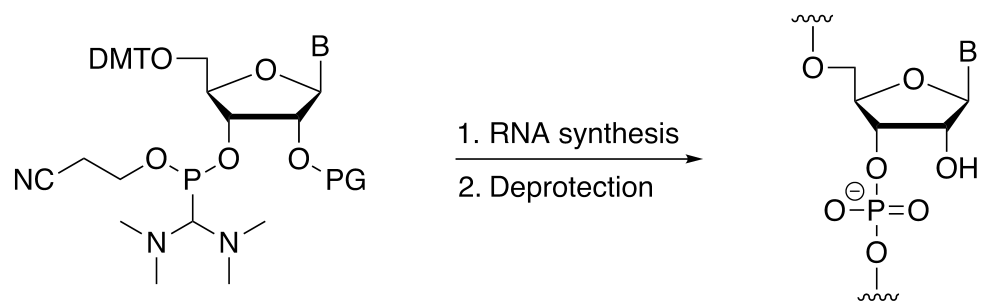

Figure 2.2 A nucleoside phosphoramidite building block for a synthesis of RNA oligonucleotides. DMT is a dimethoxytrityl, B is a nucleobase and PG is a protecting group for 2'-hydroxy group.

Using this approach, oligonucleotides containing nitroxide spin labels at specific sites have been prepared (1, Figure 2.3) was first reported by Hopkins and coworkers in 1988. ${ }^{[89]}$ The spin-labeled 2'-deoxyuridine 1 was prepared via a palladium-catalyzed Sonogashira coupling of 2,2,5,5-tetramethyl-pyrrolin-1-yloxy3-acetylene (TPA) to the nucleoside. ${ }^{[89]}$ In similar way, spin-labeled cytidine analogue $2^{[90]}$ was incorporated into DNA. These labels had improved spectroscopic properties due to restricted motion of the label in duplex DNA, compared to previous labels. ${ }^{[89,90]}$ Later, Engels and co-workers incorporated spin label $\mathbf{1}^{[91]}$ into DNA and spin labels 3-5 ${ }^{[92]}$ into RNA by an on-column coupling method during solid-phase synthesis to perform distance measurement studies of nucleic acids by PELDOR. ${ }^{[91-94]}$ Sigurdsson et al. incorporated the rigid spin label $C_{3}^{[95,96]}$ and $\mathbf{C ̧}^{\left[{ }^{[64]}\right.}$ in several different nucleic acids to study structure and dynamics. 


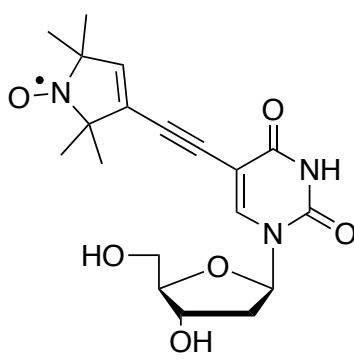

1

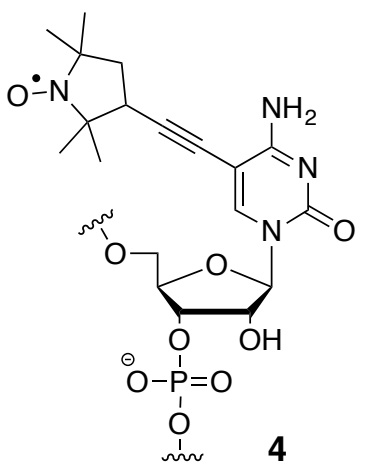

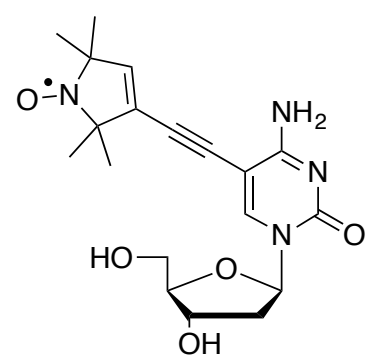

2

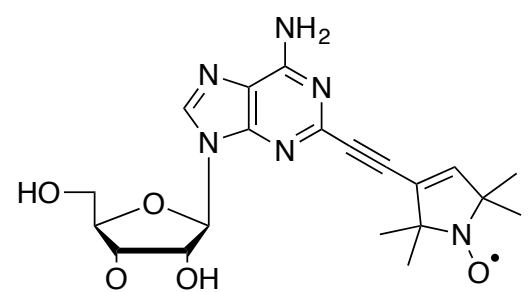

${ }^{O} \mathrm{O}-\mathrm{P}=\mathrm{P}$

O

5
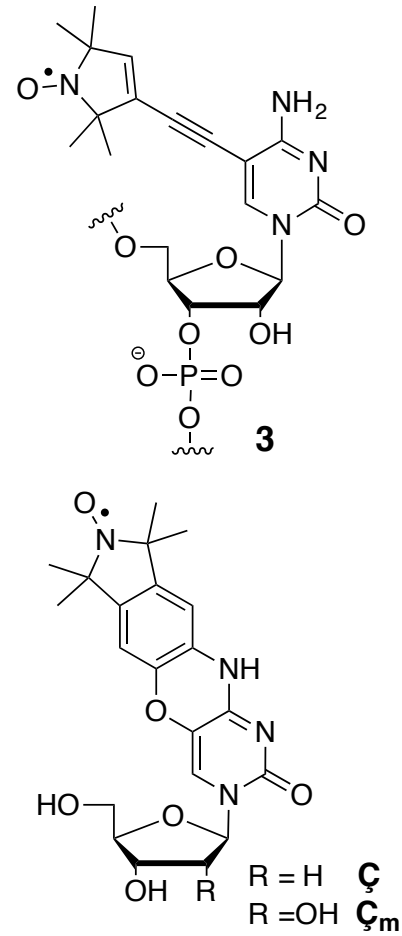

Figure 2.3 Examples of spin-labeled nucleotide that have been incorporated into nucleic acids by the phosphoramidite method.

Although, this method is very useful for SDSL, it has a few drawbacks. For example, it requires a significant synthetic effort to synthesize spin-labeled phosphoramidites. ${ }^{[64,95,96]}$ Furthermore, the spin label can get partially reduced during oligonucleotide synthesis due to its exposure to various chemical reagents which are required for oligo synthesis. ${ }^{[92,97]}$ Moreover, the purification of spinlabeled oligomer from reduced material can be tedious and nontrivial.

\subsubsection{The post-synthetic approach for SDSL}

The post-synthetic labeling is referred to labeling after synthesis of oligonucleotides. Here, the nucleotides that contain unique reactive functional groups, such as 4-thiouridine, a 2'-amino nucleoside, a phosphorothioate, an alkyne or a 2'-azido nucleoside, are incorporated at specific sites by using solid-phase synthesis of the oligonucleotides. Such modified oligonucleotides can be reacted with spin labeling reagents that contain appropriate functional groups for the attachment, to provide a variety of ways to spin label nucleic acids (Figure 2.4). For example, G. Varani and 
coworkers attached a specific spin label to RNA at 4-thio-uridine site (6). ${ }^{[98]}$ Spin labeling of exocyclic amino groups using a convertible nucleobase approach was reported by Verdine et al. ${ }^{[99,100]}$ and examples include spin-labels 7-9. ${ }^{[101,102]}$ Spin labels 10-12 ${ }^{[103,104]}$ were incorporated into nucleic acids using the "click chemistry" approach, in which alkyne-containing oligonucleotides were reacted with azidederived spin labels. Post-synthetic spin labeling of the sugar moiety has also been achieved by labeling of $2^{\prime}-\mathrm{NH}_{2}$ groups which gives urea- $(\mathbf{1 4})^{[61]}$, amide- $(\mathbf{1 5})^{[68]}$ and thiourea-derived spin-labeled nucleosides (16). ${ }^{[105]}$ Moreover, 2'-O-propargylmodified or 2'-alkynylnucleotide has been labeled post-synthetically by coppercatalyzed azide-alkyne cyclization using azide-containing spin labels which gave $13^{[106]}$ and $17,^{[107]}$ respectively. 

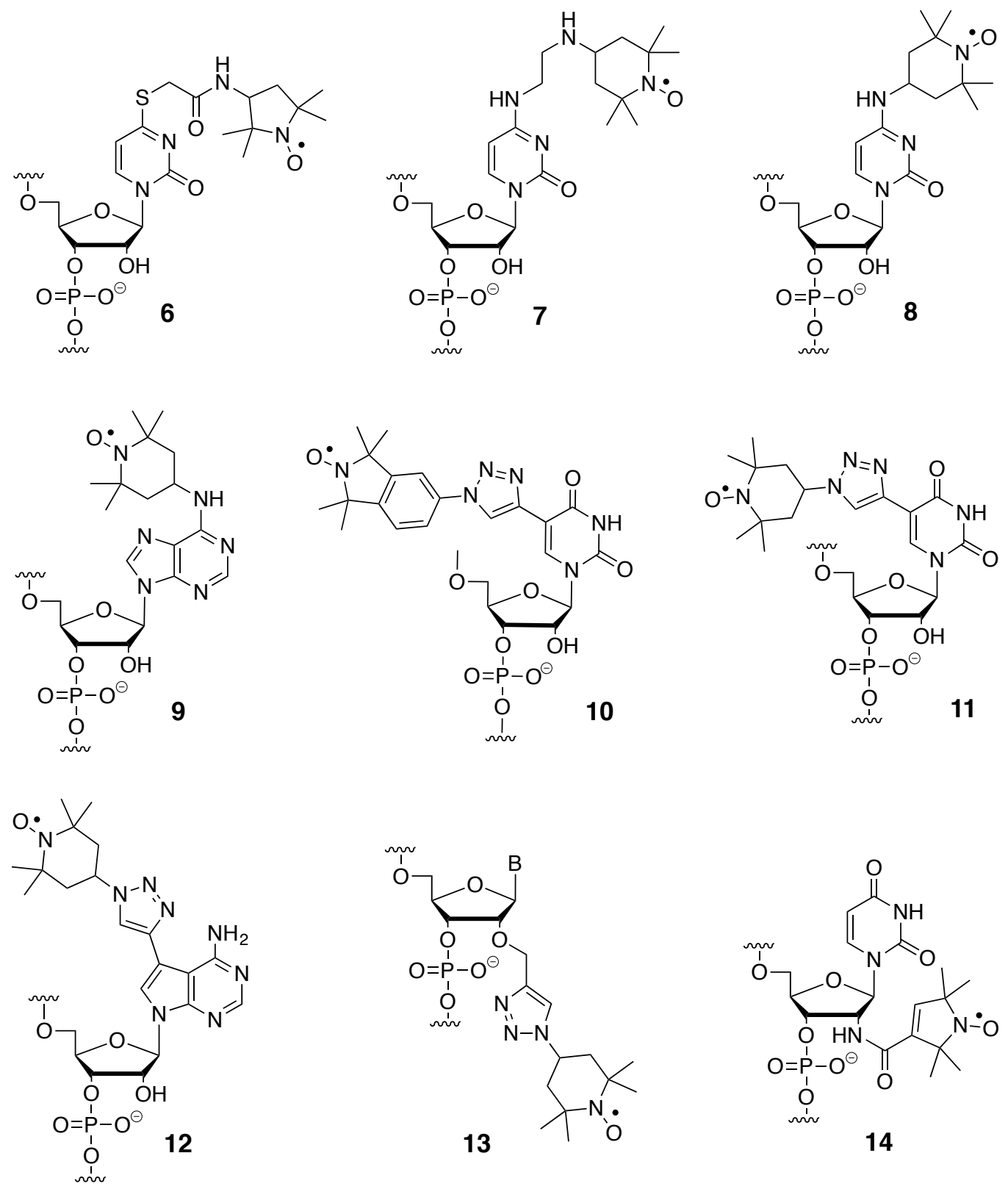

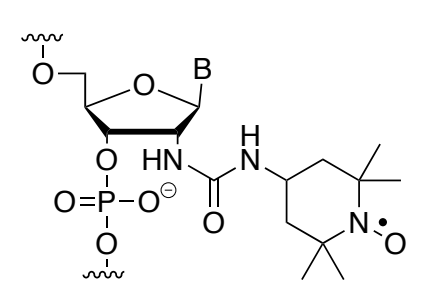

15

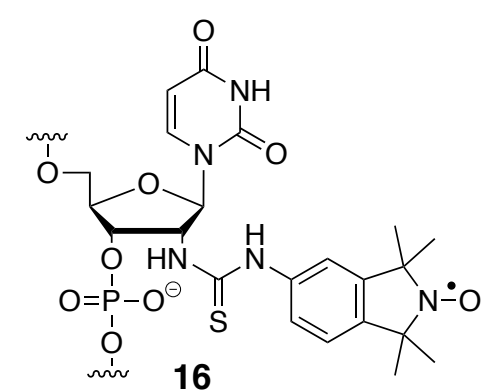

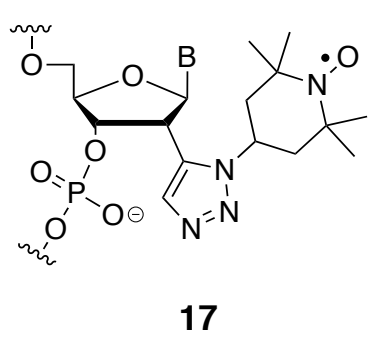

Figure 2.4 Examples of spin-labeled oligonucleotides that have been prepared by post-synthetic labeling, where B represents for uridine, adenine or cytosine. 
The post-synthetic method can be less labor intensive due to the commercial availability of many modified oligonucleotides or readily available modified phosphoramidites. Also during the spin labeling reaction, there is less chance of decomposition of the radical. Potential drawbacks of this method is incomplete labeling and possible side reactions during the spin labeling due to presence of nucleophilic groups, such as the exocyclic amino group of nucleobase, the N7 of purine and the non-bridging oxygen atoms of phosphodiester.

Given the drawbacks of the phosphoramidite and the post-synthetic approaches, we have worked on developing approaches for noncovalent spin labeling. Here, the spin label can be incorporated noncovalently by simply mixing of the spin label with a nucleic acid that contains a binding site for the spin label. More details about this method and its historical background will be discussed in the next section.

\subsubsection{Noncovalent and site-directed spin labeling (NC-SDSL) of nucleic acids}

The noncovalent spin-labeling method is based on ligand-receptor interactions that involves hydrogen bonding and/or pi-stacking interactions between the spin label and the nucleic acid. Most nucleic acids do not contain well-defined binding pockets to which organic ligands can bind, but an exception are the riboswitches that have been discovered in the last decades. ${ }^{[16-18,108]}$ Riboswitches bind selectively to the specific small organic molecules. ${ }^{[109,110]}$ Therefore, binding of a ligand to the nucleic acids generally takes place in the helical region through intercalation or groove binding. ${ }^{[111-115]}$

As previously mentioned chlorpromazine radical cation (Chapter 2.3, Figure 2.1C) is the first reported example of a radical that intercalates into the DNA. ${ }^{[83]}$ Another well-known DNA intercalator is ethidium bromide which was conjugated to a nitroxide spin label to yield 18 (Figure 2.5) in order to study the thermal dissociation of DNA-carcinogen complexes by EPR spectroscopy. ${ }^{[116]}$ Spin-labeled 
acridine analogue $\mathbf{1 9}^{[117]}$ and the nitrobenzene derivative $\mathbf{2 0}^{[118]}$ (Figure 2.5) are the additional examples that intercalate to DNA duplex. However, none of these ligands have sequence selectivity and, therefore, have limited use to study nucleic acids by EPR spectroscopy.

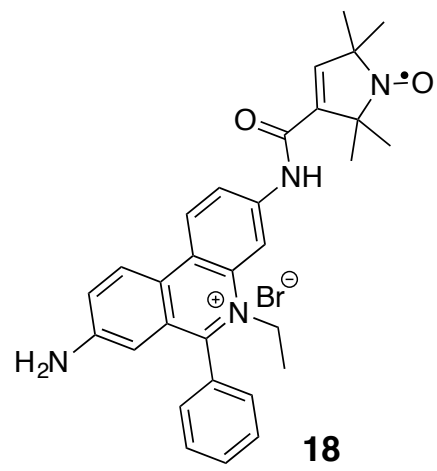

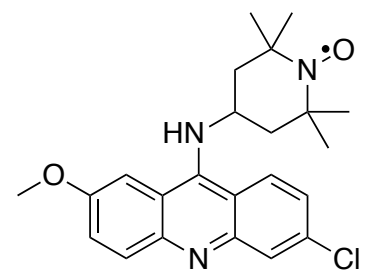

19

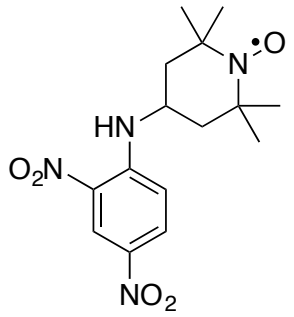

20

Figure 2.5 Structures of spin-labeled intercalators which bind to DNA duplexes.

There are several reports that describe small molecules that bind noncovalently to specific sites of nucleic acids. For example, Nakatani and coworkers reported the naphthyridinecarbamate dimer carrying TEMPO radical 21 (Figure 2.6), that binds to a guanine-guanine mismatch in DNA duplex. ${ }^{[119-121]}$ Abasic sites in duplex nucleic acids have also been used as binding sites for spectroscopic labels. For example, fluorescent compounds 23-26 (Figure 2.6) that bind to abasic sites have been developed by Taramae and co-workers for detection of single nucleotide polymorphisms in DNAs. ${ }^{[122-126]}$ Lhomme et al. used adenine-acridine conjugate 22 (Figure 2.6), for noncovalent labeling of a DNA duplex containing an abasic site, where adenine bound to an abasic site and the acridine-carrying nitroxide spin label intercalated in DNA. ${ }^{[127,128]}$ This noncovalent spin labeling approach is appealing in that the spin label can be simply mixed with the modified nucleic acids prior to EPR measurements, thus eliminating the requirement of any additional purification. Also, the spin label is not susceptible to get reduced which is often experienced during the phosphoramidite approach. 
<smiles>Cc1ccc2ccc(NC(=O)OCCCN(CCCOC(=O)Nc3ccc4ccc(C)nc4n3)CC3CC(C)(C)N([O])C(C)(C)C3)nc2n1</smiles>

21<smiles>Cc1nc2nc(N)nc(N)c2nc1C</smiles>

23<smiles>Cc1ccc2ccc(N)nc2n1</smiles>

24<smiles>Nc1nc2nccnc2c(=O)[nH]1</smiles>

25
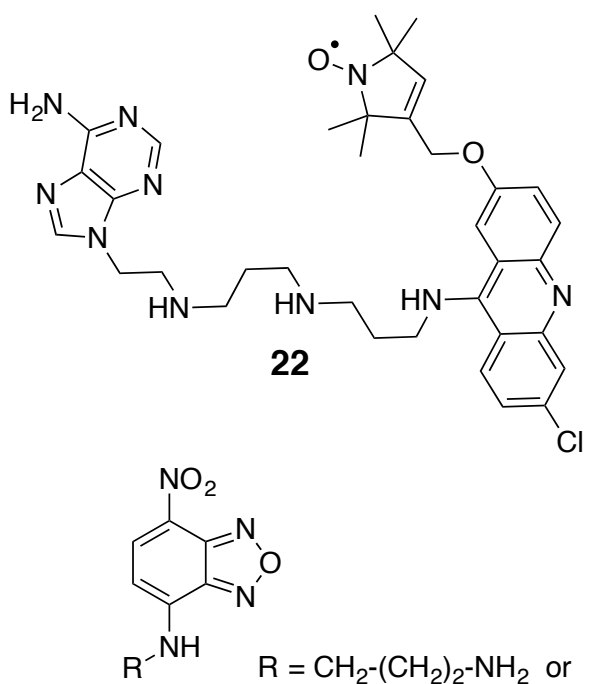

$26 \quad \mathrm{CH}_{2}-\left(\mathrm{CH}_{2}\right)_{2}-\mathrm{NMe}_{2}$

Figure 2.6 Structures of ligands used for noncovalent attachment of nucleic acids.

Recently, our research group has developed site-specific noncovalent spinlabeling of nucleic acids using abasic sites. In particular, the cytosine-derived spin label ç, binds specifically to an abasic site in duplex DNA, through forming hydrogen bonding and pi-stacking interactions (Figure 2.7), which was affirmed by using EPR spectroscopy. ${ }^{[129]}$ This label has been used for determination of distance as well as relative orientation between two spin labels in duplex DNA and in DNAprotein complexes. ${ }^{[130]}$

A drawback of ç was that it showed only partial binding to an abasic site of an RNA duplex. ${ }^{[131]}$ To circumvent this problem, a series of pyrimidine-derived nitroxides were subsequently prepared and screened for binding to both DNA and RNA duplexes. ${ }^{[131]}$ Only triazole-linked nitroxide 27 (Figure 2.7) showed complete binding to abasic sites in RNA, but it was not a useful spin label due to extensive non-specific binding to an unmodified RNA duplex.. ${ }^{[131]}$ 


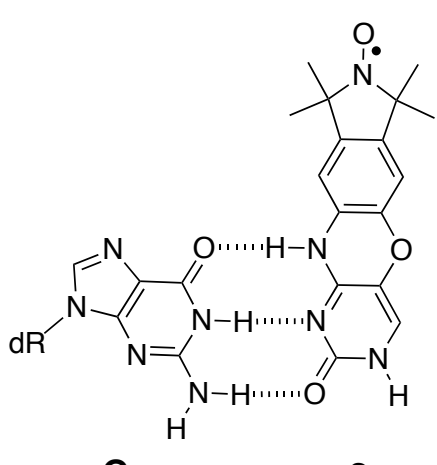

G

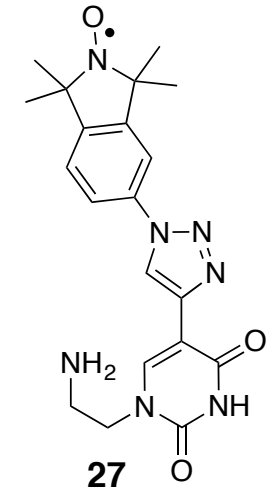

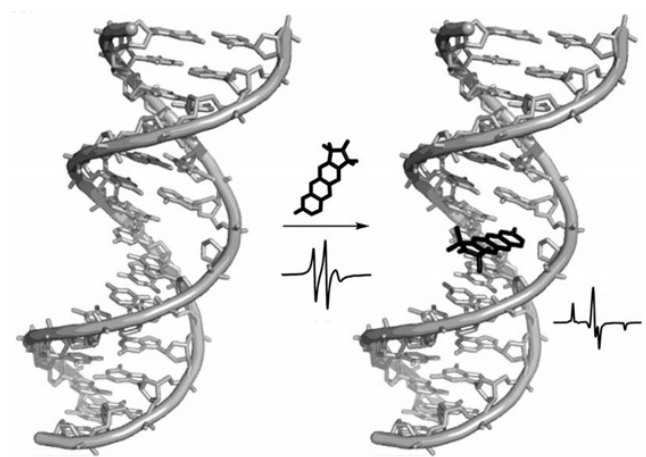

Figure 2.7 Base-pairing structure of the rigid spin label ç with guanine (G) (left) and a triazole linkednitroxide spin label 27. A molecular model of the noncovalent spin-labeling approach based on the nitroxide ç (bold) and a duplex DNA (light) containing an abasic site. The EPR spectra shown are of the unbound spin label (left) and of the bound spin label (right) in duplex DNA containing an abasic site at $-30^{\circ} \mathrm{C}$. The model figure has been reproduced with permission from Eur. J. Org. Chem., 2012, 2291-2301.

General demerits of spin-labeling through abasic sites include that the spinlabeling is only applicable for duplexes and not for single-strands. Furthermore, it has limited applicability for studies that are performed under ambient temperatures, due to low binding of spin labels at these temperatures. Also, binding affinity of the spin labels are flanking sequence dependent, for example, ç only showed full binding to a few sequences. ${ }^{[132]}$

The main focus of this thesis is to develop spin labels that have higher affinity to abasic sites. We have designed and synthesized semi-flexible purine-derived nitroxide spin labels that were studied their binding to abasic sites of DNA and RNA, described in the following chapter. 


\section{Purine-derived nitroxides for noncovalent spin-labeling of nucleic acids}

Purine bases have a larger area for stacking interactions than pyrimidines and therefore, we proposed to synthesize purine-derived nitroxide spin labels to further explore and expand the scope of the noncovalent site-directed spin labeling (NCSDSL) approach. A series of purine-based spin labels (Figure 3.1) were synthesized and the binding of these spin labels to the abasic site of duplex nucleic acids were evaluated by measurements using electron paramagnetic resonance (EPR) spectroscopy.

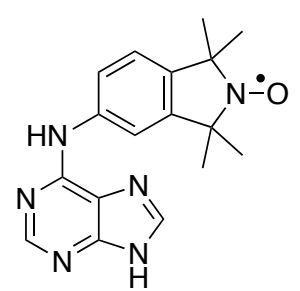

28<smiles>CC1(C)CC(Nc2nc(N)nc3[nH]cnc23)CC(C)(C)N1[O]</smiles>

31

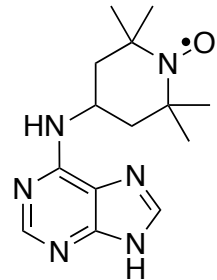

29

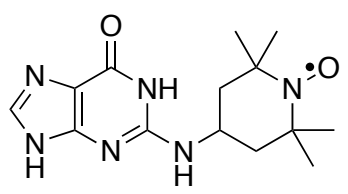

32

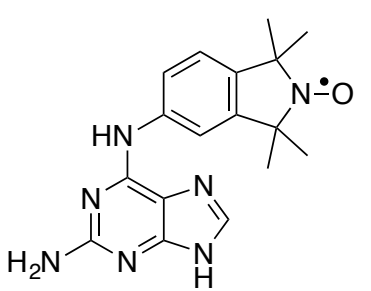

30

Figure 3.1 Structures of purine-derived nitroxide spin labels.

1,1,3,3-Tetramethylisoindolin-2-yloxyl and 2,2,6,6-tetramethylpiperidine-1oxyl (TEMPO)-nitroxides are the commonly used stable free radicals for spinlabeling. The new purine-derived spin labels (Figure 3.1), contain these nitroxides appendaged in either C2- or the C6-position, affording either adenine-, guanine or 2,6-diaminopurine-derived spin labels. Assuming formation of Watson-Crick base 
pairs to either uridine $(\mathrm{U}) /$ thymine $(\mathrm{T})$ or cytosine $(\mathrm{C})$ on the opposite strand (Figure 3.2), guanine-derived compounds 32 and Ǵ would direct the nitroxide into the minor groove, while the 6-amino modified adenine and 2,6-diamino purine spin labels 28-31 projected the label into the major groove.

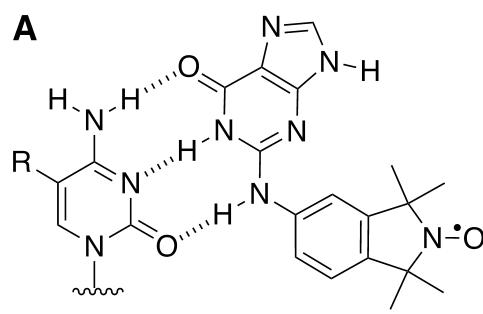

C

Ǵ

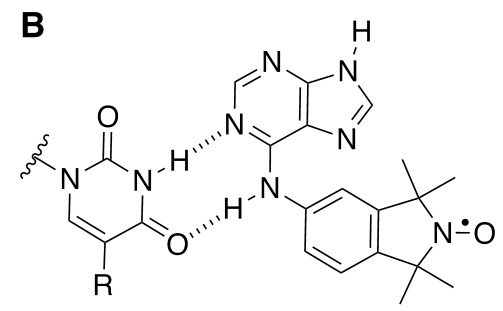

$\mathrm{U}=\mathrm{R}=\mathrm{H}$ $\mathrm{T}=\mathrm{R}=\mathrm{Me}$
28

Figure 3.2 (A) Base-pairing of spin label Ǵ with C, spin label directing into the major groove. (B) Base pairing of spin label 28 with $\mathbf{U} / \mathbf{T}$, spin label directing into the minor groove.

\subsection{Synthesis of purine-derived nitroxide spin labels}

The spin labels were synthesized from readily available halogen-derived purines through direct nucleophilic displacement reactions. Commercially available 6chloropurine 33 was heated with 34 or 35 to obtain corresponding spin-labeled derivative 28 or 29 (Scheme 3.1A and 3.1B), respectively.

A<smiles>Clc1ncnc2[nH]cnc12</smiles>

33

B<smiles>Clc1ncnc2[nH]cnc12</smiles>

33
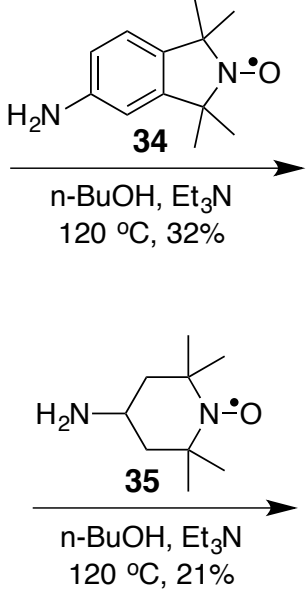<smiles>CC1(C)c2ccc(Nc3ncnc4[nH]cnc34)cc2C(C)(C)N1[O-]</smiles><smiles>CC1(C)CC(Nc2ncnc3[nH]cnc23)CC(C)(C)N1O</smiles>

Scheme 3.1 (A) Synthesis of purine-derived isoindoline nitroxide 28. (B) Synthesis of purine-derived TEMPO radical 29. 
Isoindoline- and TEMPO- derived 2,6-diaminopurines (30 and 31) were synthesized by using 2-amino-6-chloropurine, ${ }^{[133]}$ which was prepared in-house by reacting guanine with $\mathrm{POCl}_{3}$ in DMF to afford 6-chloro-2-N,Ndimethylformimidamide purine (37). Hydrolysis of compound 37 in acidic condition gave formamide-derivative 38, which under basic condition yielded 2amino-6-chloropurine (39). Compound 39 was heated with either isoindoline nitroxide $34^{[134]}$ or 4-amino TEMPO-nitroxide (35) in the presence of triethylamine and n-butanol to give spin labels 30 and 31, respectively (Scheme 3.2).

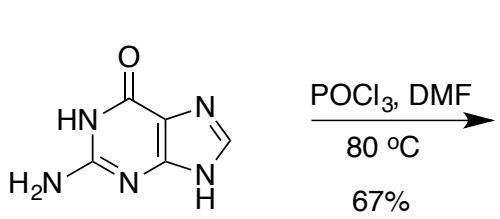

36<smiles>CN(C)/C=N/c1nc(Cl)c2nc[nH]c2n1</smiles>

37

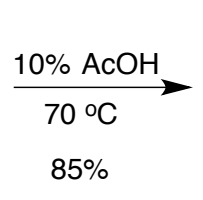<smiles>O=CNc1nc(Cl)c2nc[nH]c2n1</smiles>

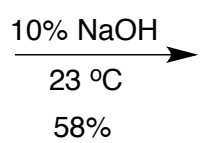<smiles>Nc1nc(Cl)c2nc[nH]c2n1</smiles>

39

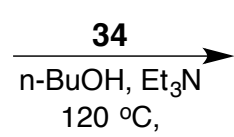

$25 \%$<smiles></smiles><smiles>CC1(C)CC(Nc2nc(N)nc3[nH]cnc23)CC(C)(C)N1O</smiles>

Scheme 3.2 Synthesis of isoindoline-derived 2,6-diamino purine 30 and TEMPO-derived 2,6diamino purine 31 .

Synthesis of compound Ǵ started with preparation of 2-bromo hypoxanthine (47) using a previously reported procedure. Commercially available thiourea (41) was treated with ethyl cyanoacetate (40) in alkaline medium using $\mathrm{NaOEt}$ in $\mathrm{EtOH}$, to obtain 6-amino-2-mercaptopyrimidin-4-ol (42) in nearly quantitative yield (Scheme 3.3). Further, C-5 nitrosation of compound 42 yielded compound 43 in $70 \%$ 
yield using the conditions described by Gibson et al. ${ }^{[135]}$ The reduction of 43 using aqueous sodium dithionite ${ }^{[135]}$ afforded 6-amino-2-mercaptopyrimidin-4-ol 44, which is required for the Traube purine synthesis. Treatment of 44 with formic acid gave 45 which was followed by cyclization in the presence of formamide that afforded 2-thioxanthine (46) in good yield. Further, bromination of 46 using bromine in $\mathrm{MeOH}$ yielded 2-bromohypoxanthine (47). Finally, compound 47 was simply heated with isoindoline nitroxide 34 in DMF to give Ǵ in moderate yield. The overall yield for the synthesis of Ǵ was 5\%.

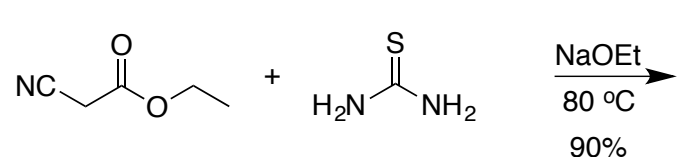

40<smiles>Nc1cc(O)nc(S)n1</smiles>

42

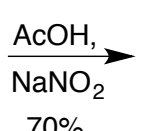

$70 \%$

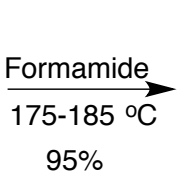

45<smiles>Nc1nc(S)nc(O)c1[N+](=O)[O-]</smiles>

43

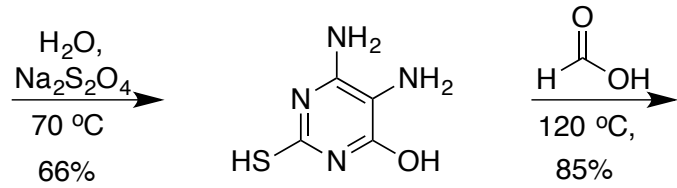

44<smiles>Nc1nc(S)nc(O)c1NC=O</smiles><smiles>O=c1[nH]c(S)nc2[nH]cnc12</smiles>

46<smiles>CC1(C)c2ccc(Nc3nc4[nH]cnc4c(=O)[nH]3)cc2C(C)(C)[N+]1=O</smiles>

Scheme 3.3 Synthesis of guanine-derived isoindoline nitroxide spin label Ǵ (G-spin).

In order to synthesize guanine-derived TEMPO-nitroxide radical (32, Scheme 3.4), 2-bromohypoxanthine (47) was reacted with 35 in DMF and triethylamine, but this resulted in a complex mixture of products. Instead, the following sequence of reactions was used. A substitution reaction of 2-amino-6-chloropurine (39) with benzyl alcohol formed 2-amino-6-benzyloxy purine, which was further treated with sodium nitrite in the presence of tetrafluoroboric acid ${ }^{[136]}$ to yield 2-fluoro-6benzyloxy purine (48). Compound 48 was subsequently reacted with 35 to give 49 
in moderate yields, which upon debenzylation gave the target compound 32 in good yields. The overall yield for the synthesis of $\mathbf{3 2}$ was $5 \%$.

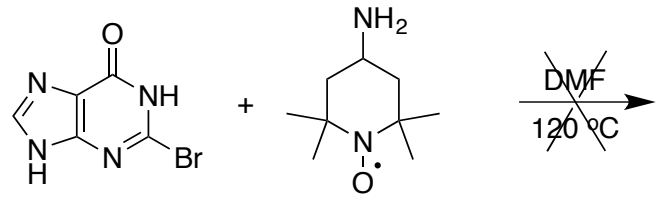

47

35<smiles>Nc1nc(Cl)c2nc[nH]c2n1</smiles>

39

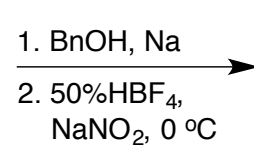

$20 \%$<smiles></smiles>

32<smiles>Fc1nc(OCc2ccccc2)c2nc[nH]c2n1</smiles>

48

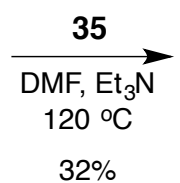

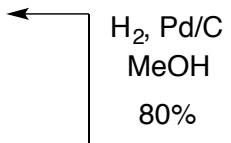

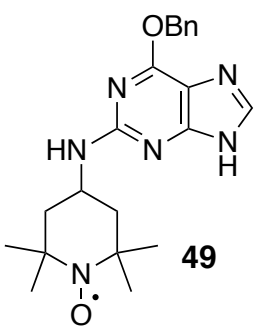

Scheme 3.4 Synthesis of guanine-derived TEMPO nitroxide spin label 32.

\subsection{Binding of purine-derived spin labels to abasic sites in duplex nucleic acids monitored by EPR spectroscopy}

\subsubsection{Binding affinity of spin labels to abasic sites in duplex DNA}

The binding affinity and specificity of spin labels 28-32 and Ǵ to abasic sites in DNA duplexes were determined by EPR spectroscopy. Each spin label was incubated with a 14-mer duplex DNA containing an abasic site and either G, T, A or C as the orphan base on the complementary strand at $-30{ }^{\circ} \mathrm{C}$ (Figure 3.3). The EPR spectrum of each spin label (Figure 3.3, far left column) showed comparatively narrow lines because of the fast tumbling motion of the radical in solution. In the presence of the DNA duplexes containing an abasic site, the appearance of a slow-moving component in the spectrum (arrows in top left spectrum) indicated binding of the spin label to the DNA. All the spin labels showed some binding affinity towards at least one DNA duplex. Two spectra indicate nearly full binding to the abasic site (Figure 3.3, spectra in boxes), for spin label Ǵ opposite to cytosine (C) and to adenine-derived spin label 28 opposite thymine (T). The TEMPO-derivatives 29, 31 and 32 showed very poor binding due to possible steric clash of the methyl groups 
of TEMPO-radical with the phosphate backbone of duplex DNA. In contrast, the 2,6-diaminopurine derivative 30 showed moderate binding to the abasic site of the DNA duplexes. To verify that the spin labels bind to the abasic site rather than nonspecifically to the DNA duplex, they were individually mixed with an unmodified 14-mer DNA duplex (Figure 3, far right column). Isoindoline spin labels Ǵ, 28 and 30 showed very minor non-specific binding $(<2 \%)$, while the others showed none. 


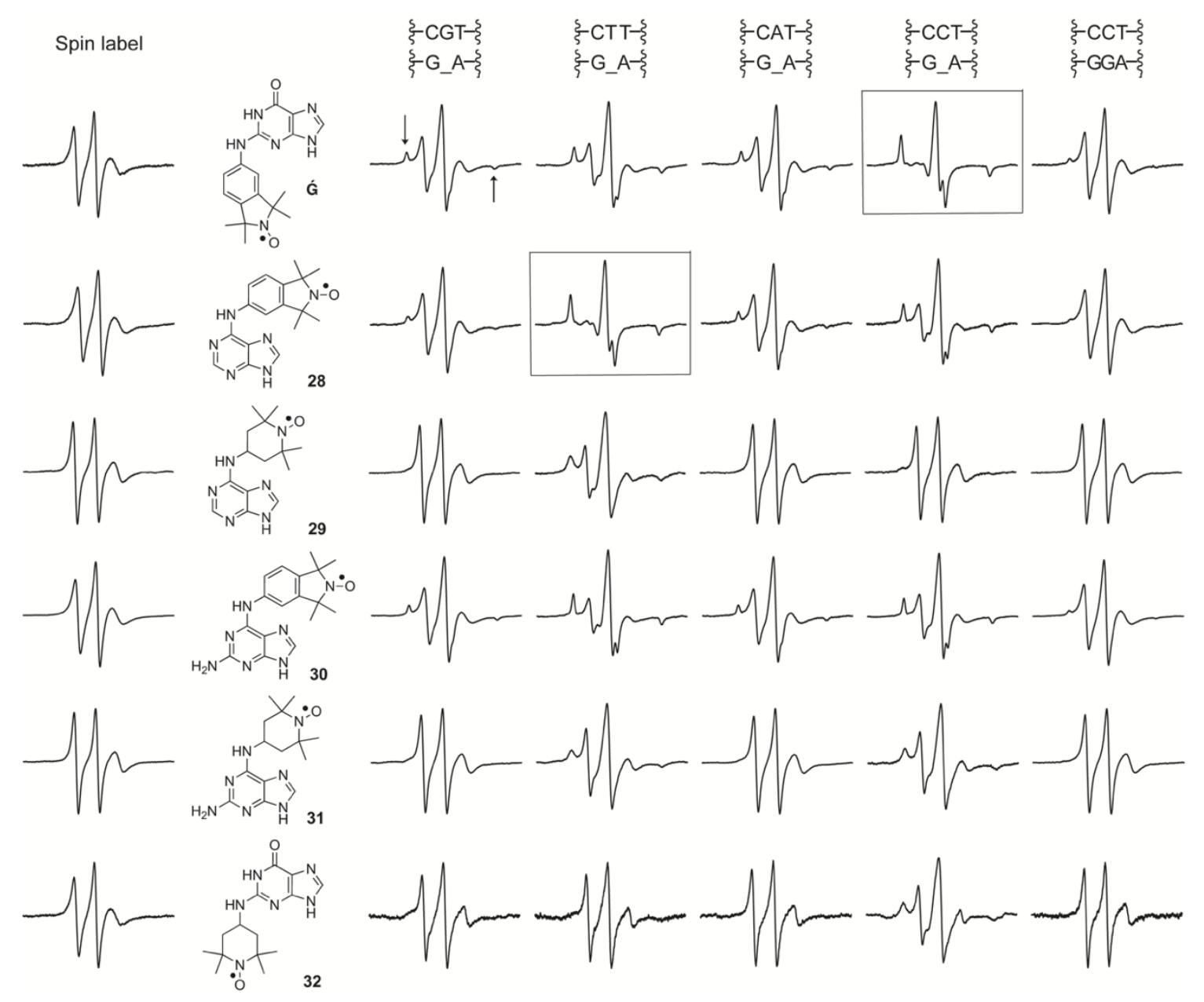

Figure 3.3 Binding of spin labels to abasic sites of DNA duplexes. EPR spectra of spin labels are shown on the far left and EPR spectra of the labels in the presence of an unmodified DNA on the far right. The central four columns of EPR spectra show the spin-label in presence of DNA duplexes containing an abasic site (denoted by "_") opposite the orphan bases G, T, A and C. Only a part of construct is shown on top; the complete DNA sequence is $5^{\prime}$-d(GACCTCG_ATCGTG)- $3^{\prime} \cdot 5^{\prime}$ d(CACGATXCGAGGTC)-3', where $X$ represents the orphan base ( $G, T, A$ or $C$ ). The arrows by the spectra in the top left corner identify a slow moving component in the EPR spectra, which indicates binding of a spin label to the nucleic acid. EPR spectrum inside the black boxes showed fully bound Ǵ and 28 to the abasic site of DNA duplex opposite to C and T, respectively. EPR spectra of spin labels $(200 \mu \mathrm{M})$ in the presence of DNA duplexes $(400 \mu \mathrm{M})$ were recorded in a phosphate buffer $(10$ $\mathrm{mM} \mathrm{Na}_{2} \mathrm{HPO}_{4}, 100 \mathrm{mM} \mathrm{NaCl}, 0.1 \mathrm{mM} \mathrm{Na} 2 \mathrm{EDTA}, \mathrm{pH} 7.0$ ) containing $30 \%$ ethylene glycol and $2 \%$ DMSO at $-30{ }^{\circ} \mathrm{C}$. The spectra were phase-corrected and aligned with respect to the height of the central peak.

The binding efficiencies of fully bound spin labels (28 and Ǵ) to their respective DNA duplexes were investigated at higher temperatures. These temperatures were well below the melting temperatures of unmodified DNA duplexes $\left(T_{\mathrm{m}}=49^{\circ} \mathrm{C}\right)$ and the duplex containing an abasic site $\left(T_{\mathrm{m}}=31^{\circ} \mathrm{C}\right)$ In this experiment, the EPR spectra of $\mathbf{2 8}$ and Ǵ, in the presence of DNA duplex containing 
an abasic site opposite to $\mathrm{T}$ and $\mathrm{C}$, respectively, were recorded at different temperatures (Figure 3.4). It was revealed that both the spin labels gradually lost their binding affinities at higher temperatures (from $-20{ }^{\circ} \mathrm{C}$ to $-0{ }^{\circ} \mathrm{C}$ ); however, comparing the slow moving components of these two spin labels, it could be concluded that Ǵ binds slightly better than 28 .
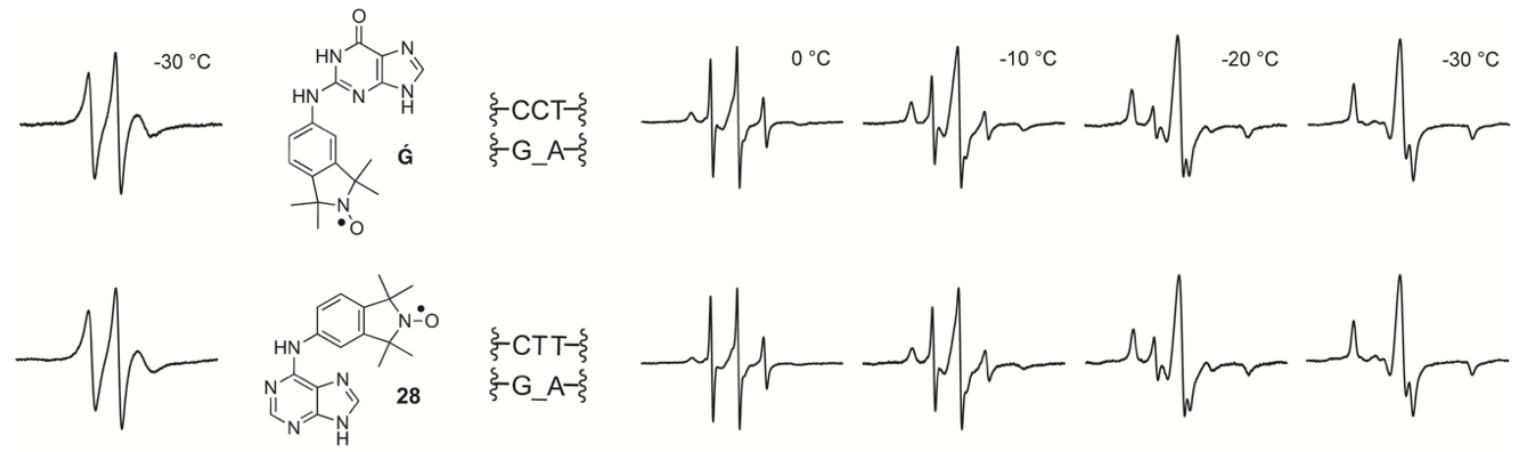

Figure 3.4 EPR spectra of binding of spin labels to an abasic site containing a DNA duplex at different temperatures. Only a part of construct is shown, the complete DNA sequence is $5^{\prime}$ $\mathrm{d}$ (GACCTCG_ATCGTG)-3'•5'-d(CACGATXCGAGGTC)-3', the abasic site (denoted by " _") and X represents orphan base $C$ or T. EPR spectra of spin labels $(200 \mu \mathrm{M})$ in the presence of RNA duplexes $(400 \mu \mathrm{M})$ were recorded in a phosphate buffer $\left(10 \mathrm{mM} \mathrm{Na}_{2} \mathrm{HPO}_{4}, 100 \mathrm{mM} \mathrm{NaCl}, 0.1 \mathrm{mM} \mathrm{Na} 2 \mathrm{EDTA}\right.$, pH 7.0) containing 30\% ethylene glycol and $2 \%$ DMSO.

\subsubsection{Binding affinity of spin labels to abasic sites in duplex RNA}

Binding affinity of these spin labels to abasic sites in RNA duplexes was also investigated (Figure 3.5). Here, the TEMPO-derived spin labels 29 and 32 also showed very limited binding, while the 2,6-diamino derivative 31 showed extensive binding opposite C. The isoindoline-derived spin labels Ǵ, 28 and $\mathbf{3 0}$ had higher affinity to the abasic sites in RNA duplexes than to DNA duplexes, showing full or nearly full binding to at least one sequence (Figure 3.5, black boxes). Ǵ bound to an abasic site opposite to $\mathrm{C}$, 2,6-diamino purine $\mathbf{3 0}$ opposite to $\mathrm{U}$ while adenine derivative 28 bound opposite to both pyrimidines, although it bound better to U. It is noteworthy that all these spin labels show the best binding to abasic sites that contain an orphan base that can form Watson-Crick base pairs with the spin label. 

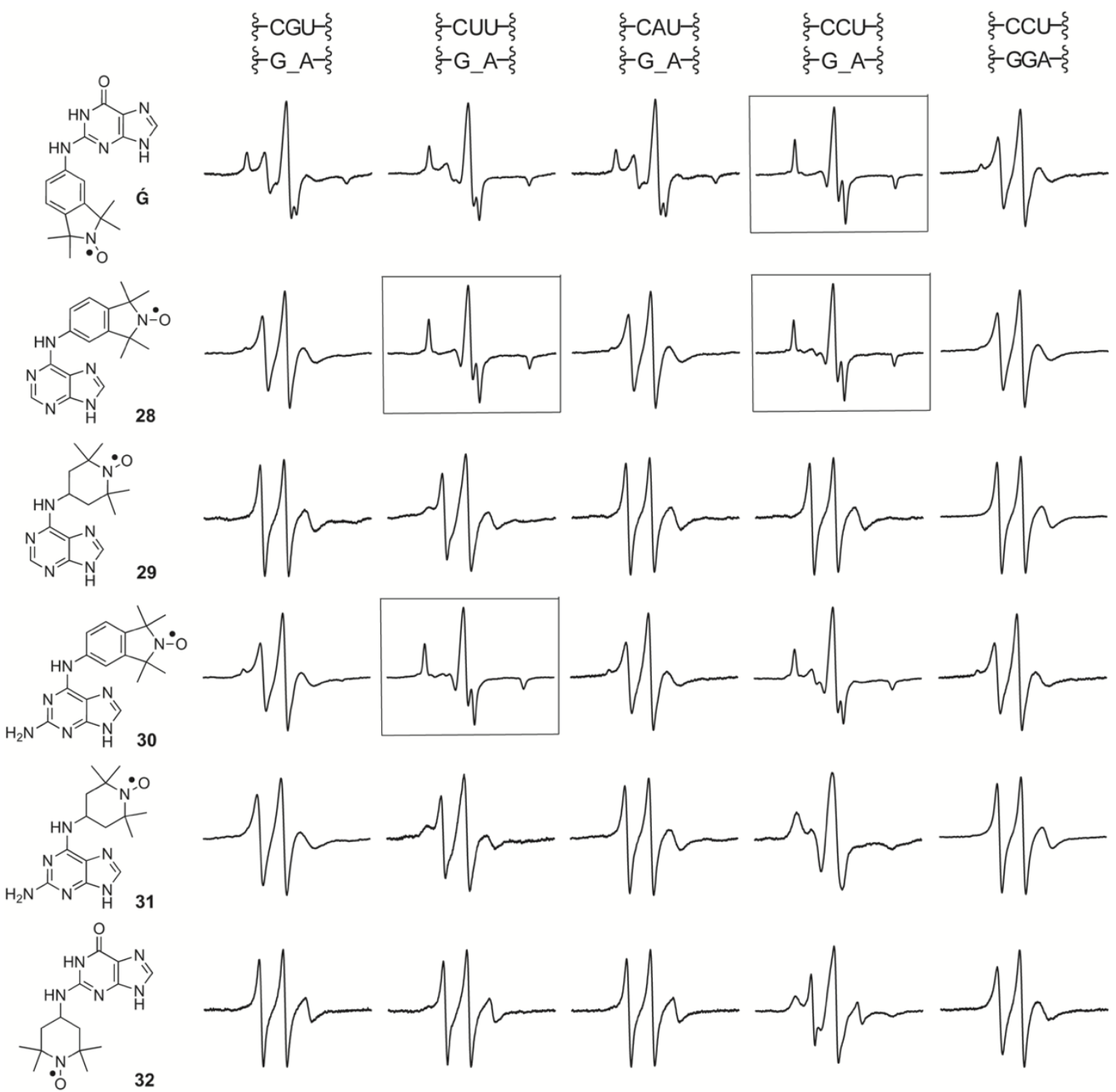

Figure 3.5 Binding of spin labels to abasic sites of RNA duplexes. EPR spectra of spin labels in the presence of an unmodified RNA on the far right. The central four columns of EPR spectra of spin labels in the presence of RNAs containing an abasic site (denoted by "_") opposite the orphan bases G, U, A and C. Only a part of construct is shown on top; the complete RNA sequence is $5^{\prime}$ GACCUCG_AUCGUG-3'•5'-CACGAUXCGAGGUC-3', where $X$ represents the orphan base $(G, U$, A or C). EPR spectra inside the black boxes are showing the binding of $\mathbf{G}, \mathbf{2 8}$ and $\mathbf{3 0}$ to abasic site of RNA duplex, in which Ǵ and $\mathbf{2 8}$ fully bound opposite to $\mathrm{C}$ and $\mathrm{U}$, whereas of $\mathbf{2 8}$ and $\mathbf{3 0}$ nearly fully bound to orphan base $U$ and C, respectively. EPR spectra of spin labels $(200 \mu \mathrm{M})$ in the presence of RNA duplexes $(400 \mu \mathrm{M})$ were recorded in a phosphate buffer $\left(10 \mathrm{mM} \mathrm{Na}_{2} \mathrm{HPO}_{4}, 100 \mathrm{mM} \mathrm{NaCl}, 0.1\right.$ $\mathrm{mM} \mathrm{Na}$ EDTA, pH 7.0) containing $30 \%$ ethylene glycol and $2 \%$ DMSO at $-30{ }^{\circ} \mathrm{C}$.

In order to obtain information about the relative affinities of the isoindolinederivative spin labels Ǵ, 28 and 30, the temperature dependence of their binding was investigated (Figure 3.6). These temperatures were well below the melting temperatures of unmodified RNA duplexes $\left(T_{\mathrm{m}}=61^{\circ} \mathrm{C}\right)$ and the duplex containing 
an abasic site $\left(T_{\mathrm{m}}=41^{\circ} \mathrm{C}\right)$. Spin label $\mathrm{G}$ was by far the best binder, as extensive binding was observed even at $20^{\circ} \mathrm{C}$ at which temperature spin labels 28 and $\mathbf{3 0}$ showed nearly no binding.
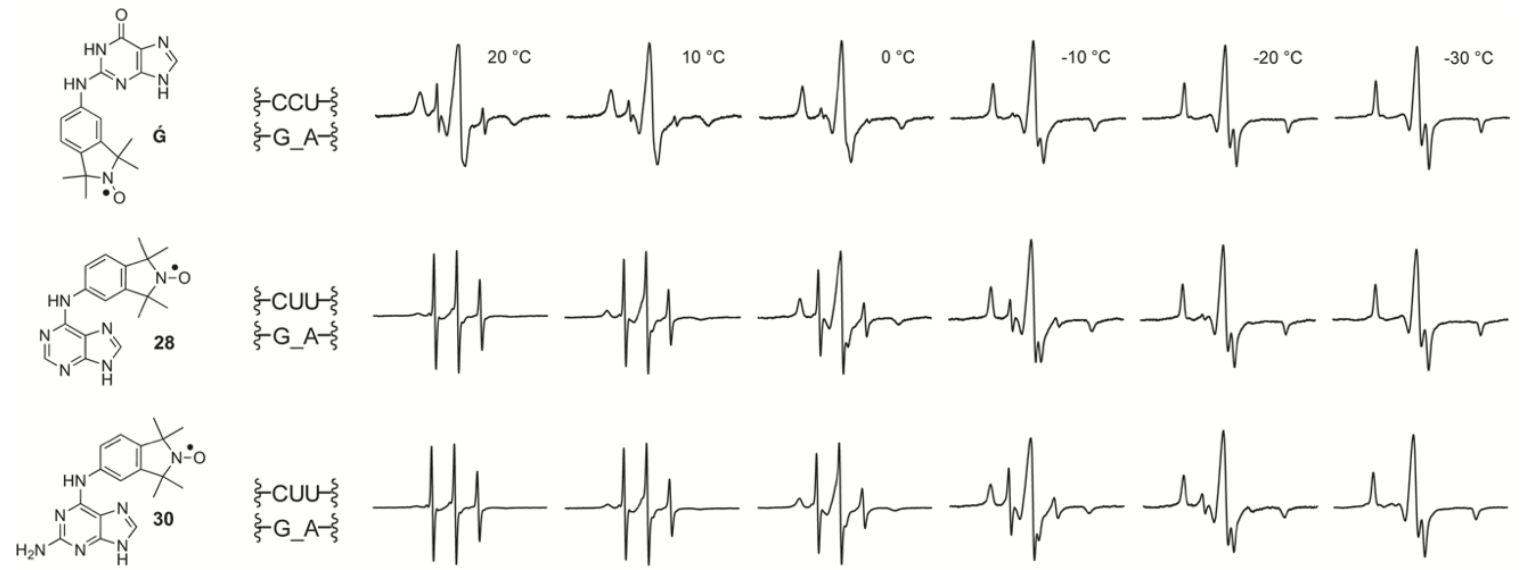

Figure 3.6 EPR spectra of binding of spin labels to an abasic site containing a RNA duplex at different temperatures. Only a part of construct is shown, the complete RNA sequence is $5^{\prime}$ GACCUCG_AUCGUG)-3'•5'-CACGAUXCGAGGUC-3", the abasic site (denoted by "-") and X represents orphan base $C$ or $U$. EPR spectra of spin labels $(200 \mu \mathrm{M})$ in the presence of RNA duplexes $(400 \mu \mathrm{M})$ were recorded in a phosphate buffer $\left(10 \mathrm{mM} \mathrm{Na}_{2} \mathrm{HPO}_{4}, 100 \mathrm{mM} \mathrm{NaCl}, 0.1 \mathrm{mM} \mathrm{Na} 2 \mathrm{EDTA}\right.$, pH 7.0) containing 30\% ethylene glycol and 2\% DMSO.

\subsubsection{Determination of dissociation constants $\left(K_{d}\right)$}

An in-house MATLAB-based program was used to calculate dissociation constants $\left(K_{d}\right)^{[129]}$ The EPR spectrum of the $\mathbf{G}$ and the EPR spectrum of $G$ in the presence of duplex nucleic acid containing an abasic site were double-integrated ${ }^{[137,138]}$ and normalized with respect to their area. The normalized spectrum of Ǵ was fractionally subtracted from the normalized spectrum of $\mathbf{G}$ in the presence of a duplex nucleic acid to get the visually best fit to a fully bound spectrum. The fraction value $\propto$ was used to calculate the dissociation constant $\left(K_{\mathrm{d}}\right)$ using the following equation 1:

$$
K_{\mathrm{d}}=\frac{[\mathrm{Y}-(1-\propto) * \mathrm{X}][\propto * \mathrm{X}]}{(1-\propto) * \mathrm{X}}
$$

equation 1 , 
where $\mathrm{X}$ is an initial concentration of the spin label and $\mathrm{Y}$ is an initial concentration of the duplex nucleic acid that contains an abasic site. In a similar way, the dissociation constant of Ǵ to abasic site of RNA duplex was determined at $20{ }^{\circ} \mathrm{C}$ and the $K_{d}$ was found to be $6.15 \times 10^{-6} \mathrm{M}^{[129]}$

\subsubsection{Specificity of binding of Ǵ to abasic sites in RNA duplex}

The binding specificity of Ǵ to RNA duplexes was determined by two methods. First, the spin label (Ǵ) was titrated into a solution containing a fixed concentration of an RNA duplex containing an abasic site opposite to $\mathrm{C}$ and the EPR spectra were recorded at $-20^{\circ} \mathrm{C}$ (Figure 3.7A). For 0.5 and 1.0 eq. of $\mathbf{G}$, the spin label was fully bound, whereas, both the bound and excess free spin label were observed for 2.0 eq. of the spin label. Thus, after saturation of the abasic binding site, the excess spin label does not bind to the duplex. Second, an unmodified RNA duplex was mixed with the spin label and the EPR spectra were recorded at $-20^{\circ} \mathrm{C}$ and $-30{ }^{\circ} \mathrm{C}$ (Figure 3.7B). Minor non-specific binding (<5\%) was observed at $-30{ }^{\circ} \mathrm{C}$ but less than $1 \%$ at $-20{ }^{\circ} \mathrm{C}$. These experiments clearly show that the spin label shows negligible nonspecific binding under conditions where the abasic site is fully saturated.

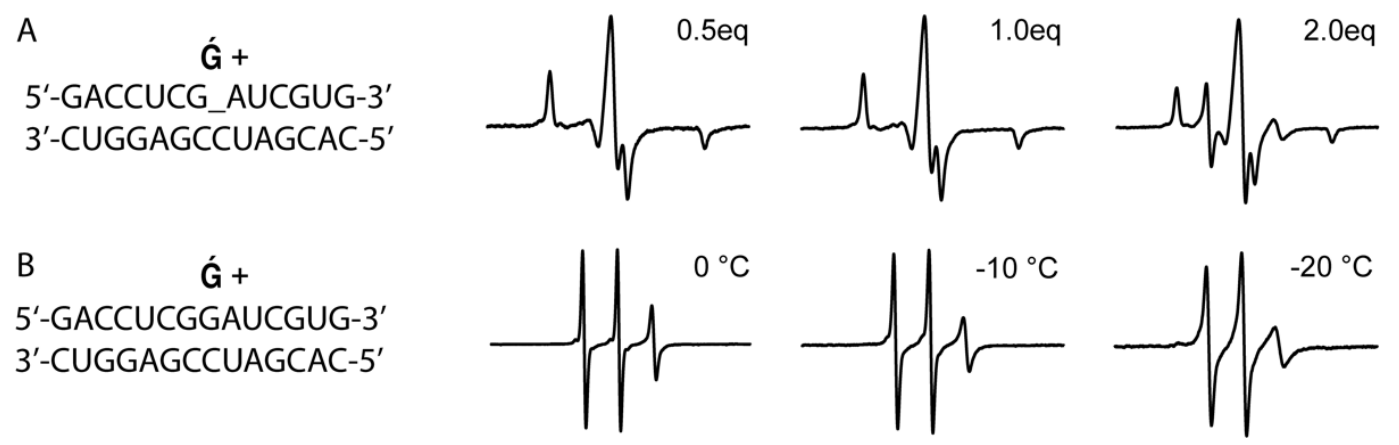

Figure 3.7 (A) EPR spectra for a titration of Ǵ to an RNA duplex (200 $\mu \mathrm{M})$ containing an abasic site opposite C, using 0.5 eq. (left), 1.0 eq. (middle) and 2 eq. (right) of the spin label at $-20^{\circ} \mathrm{C}$. (B) EPR spectra of $\mathbf{G}(200 \mu \mathrm{M})$ in the presence of an unmodified RNA $(200 \mu \mathrm{M})$ duplex. Measurements were recorded in a phosphate buffer $\left(10 \mathrm{mM} \mathrm{Na}_{2} \mathrm{HPO}_{4}, 100 \mathrm{mM} \mathrm{NaCl}, 0.1 \mathrm{mM}\right.$ Na2EDTA, pH 7.0) containing 2\% DMSO and 30\% ethylene glycol. 
The specificity of binding was also investigated by a competition experiment, in which four different samples were prepared, where the stoichiometry of hypoxanthine was varied from 0 to 10 equivalents while maintaining fixed concentrations of Ǵ $(200 \mu \mathrm{M})$ and a duplex RNA $(200 \mu \mathrm{M})$ containing an abasic site (Figure. 3.8). Hypoxanthine has previously been used to rescue the catalytic activity of a hammerhead ribozyme containing an abasic site. ${ }^{[139]}$ Not unexpectedly, hypoxanthine (I) has a lower affinity to the abasic site than $\mathbf{G}$, but it is clear that it is competing with Ǵ for binding to the abasic site.

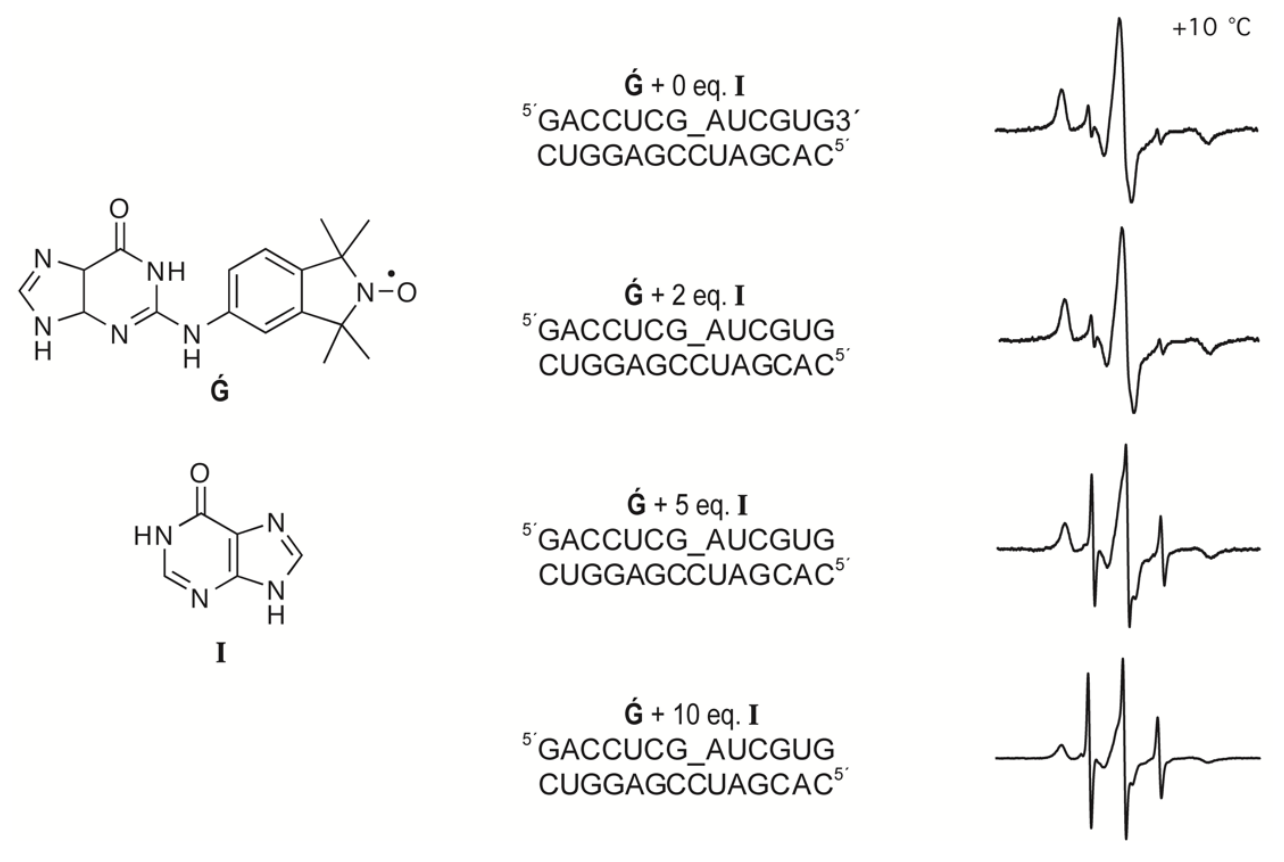

Figure 3.8 CW-EPR spectra of Ǵ $(200 \mu \mathrm{M})$ in the presence of a duplex RNA $(200 \mu \mathrm{M})$ containing an abasic site (_), along with increasing concentration of hypoxanthine (I) (0-10 equiv.). The EPR spectra were recorded in a phosphate buffer $\left(10 \mathrm{mM} \mathrm{Na}_{2} \mathrm{HPO}_{4}, 100 \mathrm{mM} \mathrm{NaCl}, 0.1 \mathrm{mM} \mathrm{Na} 2 \mathrm{EDTA}, \mathrm{pH} 7.0\right)$ containing $2 \%$ DMSO and $30 \%$ ethylene glycol at $10{ }^{\circ} \mathrm{C}$.

In a similar way, another competition experiment was also performed in the presence of spin-deleted compound 50 with Ǵ, for which the latter was synthesized by reduction of Ǵ using sodium sulfide (Figure 3.5). 


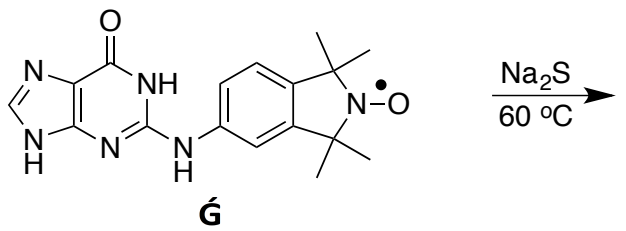<smiles>CC1(C)NC(C)(C)c2cc(Nc3nc4[nH]cnc4c(=O)[nH]3)ccc21</smiles>

Scheme 3.5 Synthesis of compound 50.

It was anticipated that both 50 and $\mathbf{G}$ should have similar binding affinity to the RNA duplex, due to the close structural similarities and therefore, $\mathbf{5 0}$ can be useful in competition experiment to displace the Ǵ binding. To perform this experiment three different samples were prepared, where the stoichiometry of $\mathbf{5 0}$ was varied from 0 to 2 equivalents while maintaining fixed concentrations of $\mathbf{G}(200 \mu \mathrm{M})$ and a duplex RNA $(200 \mu \mathrm{M})$ containing an abasic site. This study results that, at $-20{ }^{\circ} \mathrm{C}$ (Figure 3.9) when 1 eq. of $\mathbf{5 0}$ was used, Ǵ showed ca. $80 \%$ of its binding, when the concentration of 50 was increased to 2 eq., the binding of Ǵ decreased (ca. 30\% binding) was observed. These competition studies revealed that $\mathbf{5 0}$ displaced Ǵ in the binding site of RNA duplex, but the binding of $\mathbf{G}$ is better than 50 at $-20{ }^{\circ} \mathrm{C}$.

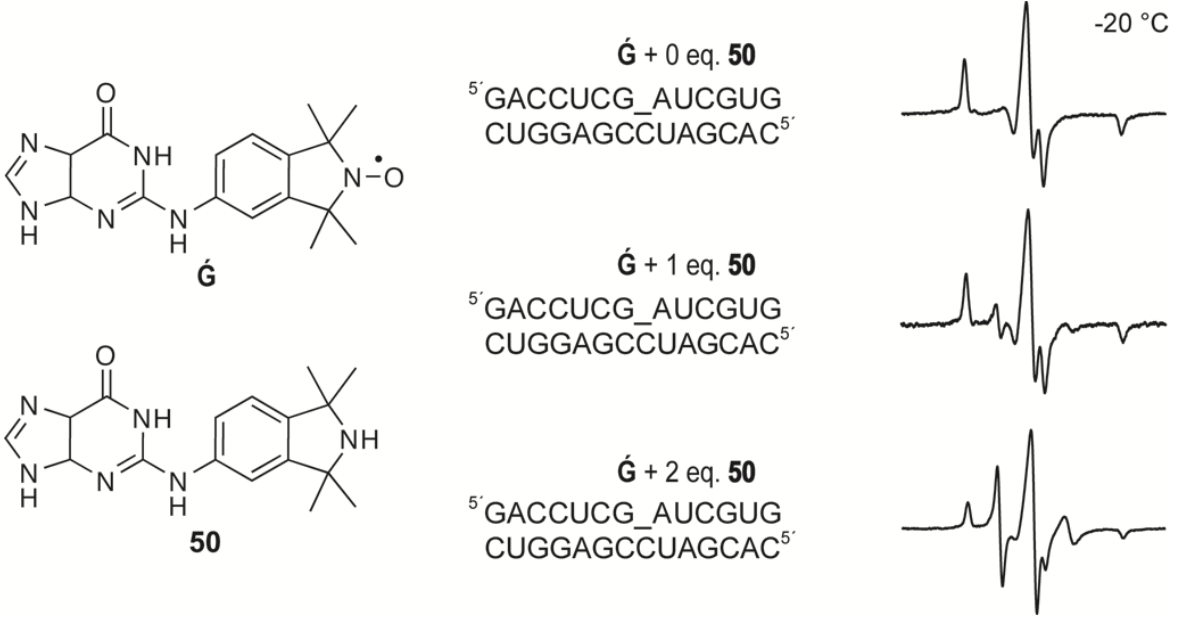

Figure 3.9 CW-EPR spectra of Ǵ $(200 \mu \mathrm{M})$ in the presence of a duplex RNA $(200 \mu \mathrm{M})$ containing an abasic site (_), along with increasing concentration of 50 (0-2 eq.). The EPR spectra were recorded in a phosphate buffer $\left(10 \mathrm{mM} \mathrm{Na}_{2} \mathrm{HPO}_{4}, 100 \mathrm{mM} \mathrm{NaCl}, 0.1 \mathrm{mM} \mathrm{Na} 2 \mathrm{EDTA}, \mathrm{pH}\right.$ 7.0) containing $2 \%$ DMSO and $30 \%$ ethylene glycol at $-20^{\circ} \mathrm{C}$. 


\subsubsection{Binding affinity of Ǵ to DNA-RNA hybrids}

DNA-RNA hybrids are heterogeneous nucleic acids and are key intermediates in many important biological processes. ${ }^{[140-145]}$ These hybrids are recognized by Ribonuclease H (RNaseH) and have been used for biomedical technologies such as antisense therapies. ${ }^{[142,146]}$ Structures of several hybrids have been characterized using NMR spectroscopy ${ }^{[147-149]}$ and X-ray crystallography ${ }^{[150-153]}$ and have been shown to exist in an A-form duplex. Spin-labeling of DNA-RNA hybrid duplexes have, to our knowledge, not been explored before. Given the extensive binding of the spin label Ǵ to abasic sites in RNA, we selected it to probe its binding to abasic sites in DNA-RNA duplexes.

To evaluate the binding affinity of Ǵ to the abasic site of DNA-RNA hybrid duplexes, two 14-mer duplexes were prepared. The first duplex contained an abasic site in the DNA strand (Figure 3.10, first row) and in the second duplex, the abasic site was placed in the RNA strand (Figure 3.10, second row). Ǵ bound fully to both hybrid duplexes at $-30{ }^{\circ} \mathrm{C}$; extensive binding was even observed at $0{ }^{\circ} \mathrm{C}$. However, increasing the temperature to $20^{\circ} \mathrm{C}$ resulted in almost complete loss of binding.

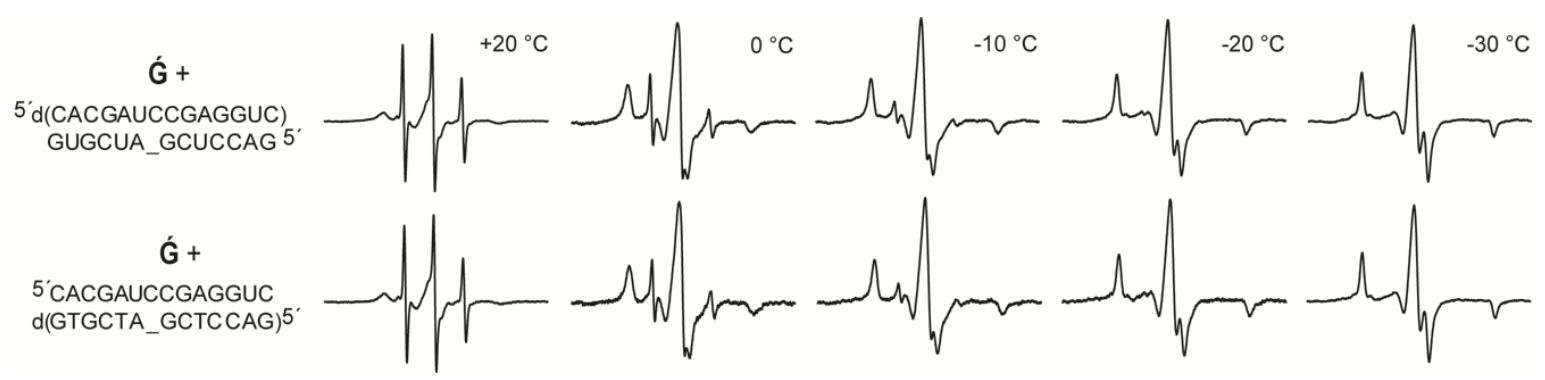

Figure 3.10 Binding of spin label Ǵ to abasic site of DNA-RNA hybrid duplexes. The DNA-RNA duplex contained an abasic site in DNA strand (first row), whereas RNA-DNA duplex contained an abasic site in RNA strand (second row) and the abasic site denoted by "_". EPR spectra of Ǵ (200 $\mu \mathrm{M})$ in the presence of DNA-RNA hybrid $(400 \mu \mathrm{M})$ were recorded in a phosphate buffer $(10 \mathrm{mM}$ $\mathrm{Na}_{2} \mathrm{HPO}_{4}, 100 \mathrm{mM} \mathrm{NaCl}, 0.1 \mathrm{mM} \mathrm{Na} 2 \mathrm{EDTA}$, pH 7.0) containing 30\% ethylene glycol and 2\% DMSO.

We determined the binding affinities of Ǵ to all the duplexes (DNA-DNA, RNA-RNA and DNA-RNA) where the abasic site was placed opposite to C (Figure 3.11). G had the highest affinity to the RNA-RNA duplex $\left(K_{d}=1.46 \times 10^{-7} \mathrm{M}\right)$, the 
second highest to the DNA-RNA hybrids $\left(K_{d}=9.75 \times 10^{-7} \mathrm{M}\right)$ and the lowest affinity to the DNA-DNA duplexes $\left(K_{d}=60.17 \times 10^{-7} \mathrm{M}\right)$ at $0{ }^{\circ} \mathrm{C}$. Thus the binding affinity of Ǵ decreased 6-fold when bound to DNA-RNA hybrids and a 41-fold when it was bound to the DNA-DNA duplex, compared to the RNA-RNA duplex.

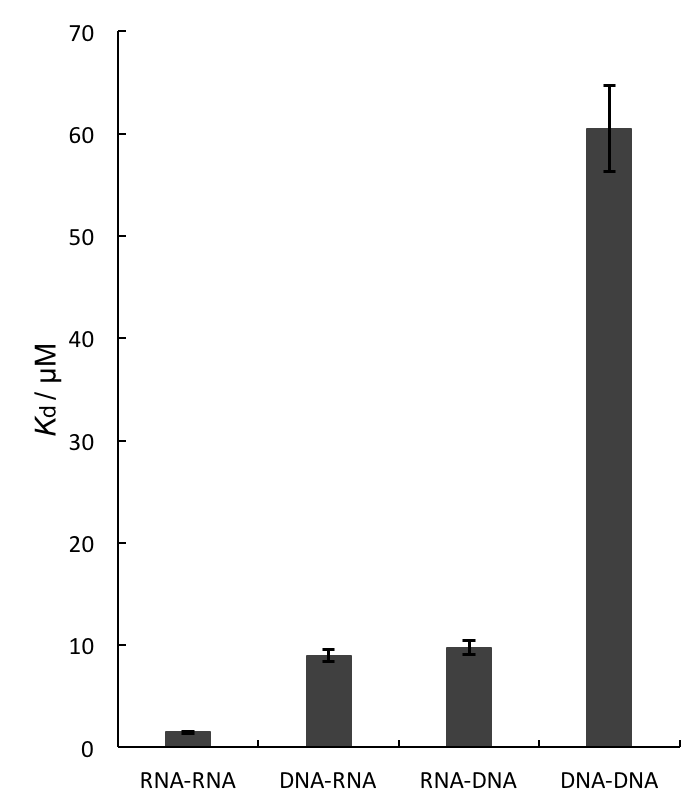

Figure 3.11 A plot of the dissociation constant $\left(K_{d}\right)$ of Ǵ-binding to RNA-RNA, DNA-RNA and DNARNA duplexes containing an abasic site opposite cytosine $(\mathrm{C})$ at $0{ }^{\circ} \mathrm{C}$.

\subsection{Effect of structural changes in RNA duplexes on Ǵ- binding}

Three main factors contribute to spin-label binding to an abasic site. First, hydrogen bonding of the spin label to the orphan base on the opposing strand, as described above. Second, the identity of the bases flanking the abasic site will affect the stacking interaction with the spin label. Third, placement of the abasic site closer to the end of the duplex might compromise the structural integrity of the abasic binding site, since terminal base pairs are more dynamic than the central base pairs. ${ }^{[154]}$ We decided to investigate the latter two factors in RNA using the spin label (Ǵ) with the highest affinity. 


\subsubsection{Effect of the location of the abasic site relative to the duplex end}

To investigate the effect of the location of the abasic site relative to the duplex end on spin label binding, four different 14-mer RNA duplexes (III-VI, Figure 3.12) were prepared, such that the position of the abasic site was moved one base pair at a time from the 5 '-end towards the centre of the duplex. Quite remarkably, Ǵ showed extensive binding when a single C-overhang was placed at the end of the duplex (RNA III), similar to the degree of binding to an abasic site placed one base pair away from the end of the duplex (RNA IV). When the abasic site (RNA V) was placed at the third position from the terminus, the spin label bound fully at $-30{ }^{\circ} \mathrm{C}$. However, the data recorded at $-20^{\circ} \mathrm{C}$ showed that the abasic site needs to be at least at the fourth position from the end (RNA VI) to achieve the same extent of binding as when the abasic site is located at the center of the duplex.
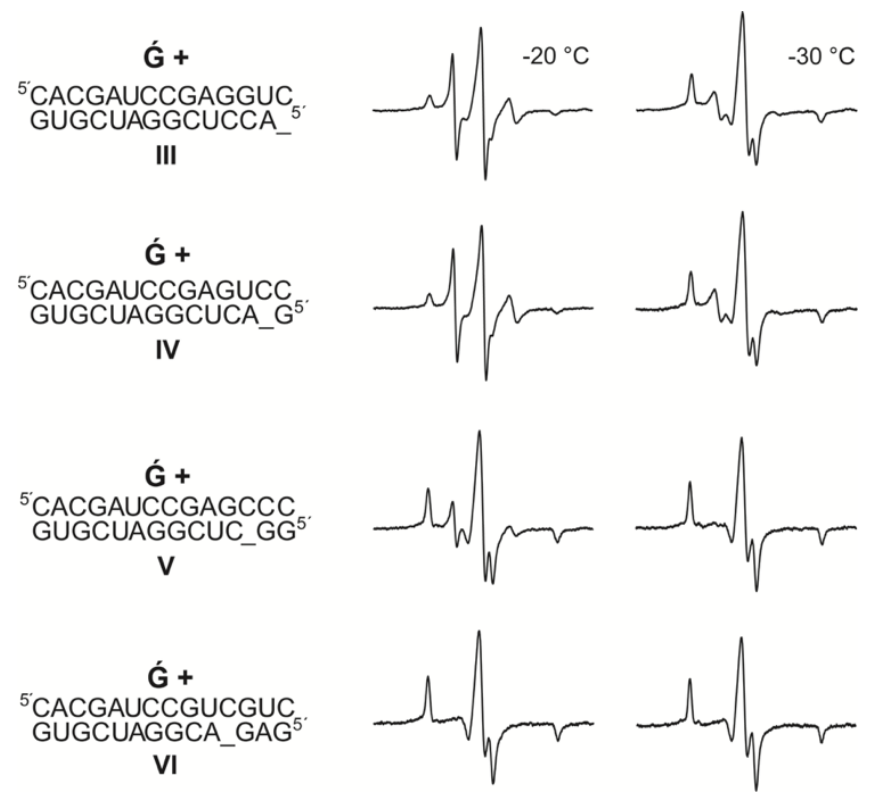

Figure 3.12 Binding of Ǵ $(200 \mu \mathrm{M})$ to RNA $(400 \mu \mathrm{M})$ duplexes (III-VI) containing abasic sites (denoted by "_"), where the location of abasic site is moving from 5 '-end to the centre of duplex. All EPR spectra were recorded in a phosphate buffer $\left(10 \mathrm{mM} \mathrm{Na} 2 \mathrm{HPO}_{4}, 100 \mathrm{mM} \mathrm{NaCl}, 0.1 \mathrm{mM}\right.$ $\mathrm{Na}$ EDTA, pH 7.0) containing 30\% ethylene glycol and $\%$ DMSO. 


\subsubsection{Effect of flanking sequence on binding of Ǵ}

To investigate the binding efficiency of $\mathbf{G}$ as a function of the identity of the base pairs immediately flanking the abasic site, a series of sixteen 14-mer RNA duplexes, with all possible combinations of the flanking bases, were prepared and incubated with Ǵ. Visual inspection of the EPR spectra (Figure 3.13) revealed relatively minor variations in the extent of binding between the flanking sequences.

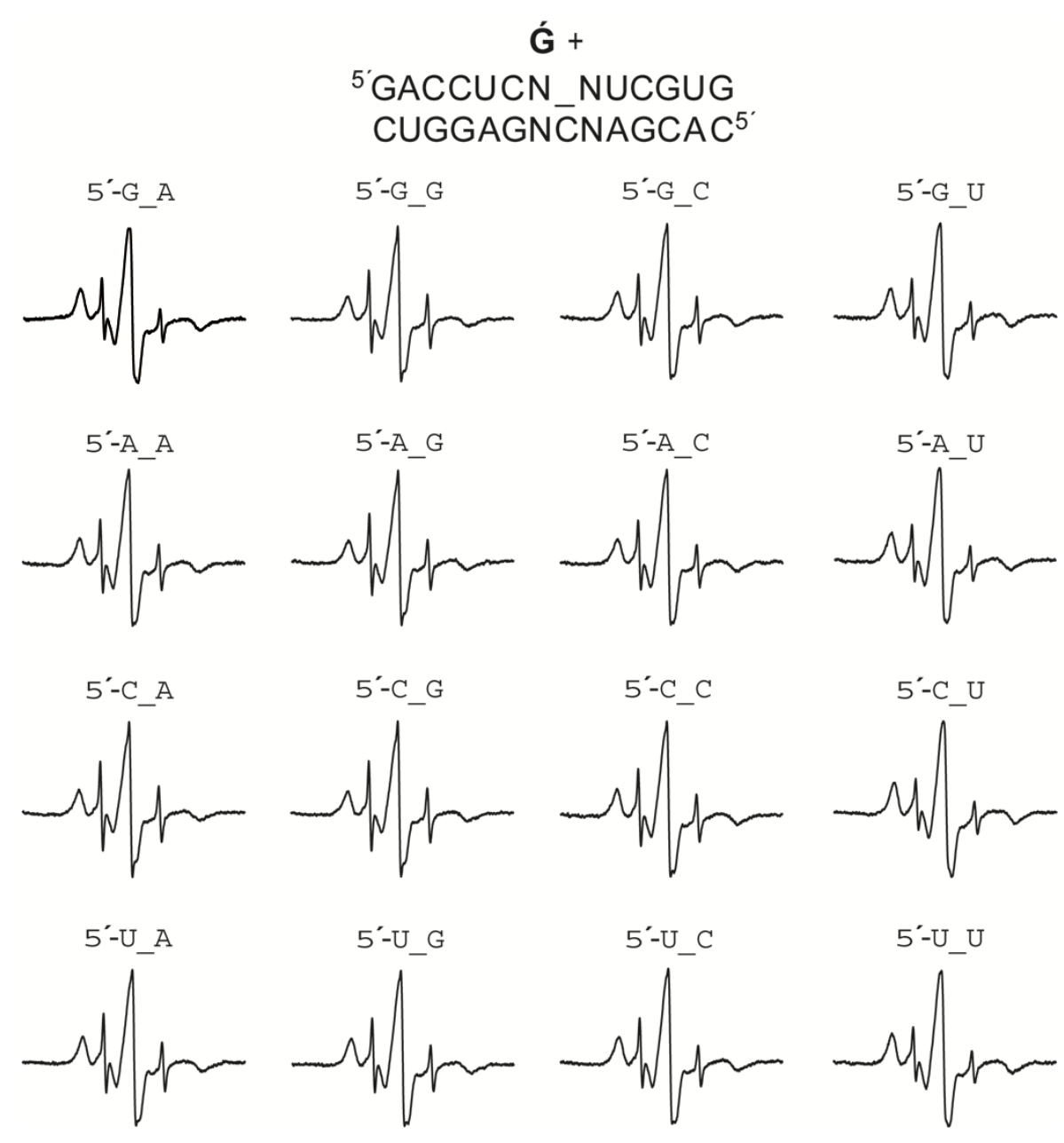

Figure 3.13 EPR spectra of binding of Ǵ $(200 \mu \mathrm{M})$ to duplex RNAs $(400 \mu \mathrm{M})$ containing different flanked bases to the abasic site "_." EPR spectra were recorded in phosphate buffer pH 7.0, containing $30 \%$ ethylene glycol and $2 \%$ DMSO at $20^{\circ} \mathrm{C}$.

The binding was quantified by determining the dissociation constant $\left(K_{d}\right)$ at 20 ${ }^{\circ} \mathrm{C}$ for all the flanking sequences. As can be seen in Figure 3.14, which shows a bar graph of the dissociation constant as a function of the flanking sequence, the variation in $K_{\mathrm{d}}$ is within a factor of two. For comparison, up to 15-fold difference in 
the $K_{\mathrm{d}}$ was observed between flanking sequences when binding of the spin label ç to abasic sites in DNA duplexes. ${ }^{[132]}$ For a given base at the $5^{\prime}$-side of the abasic site, the highest affinity for Ǵ was observed for a U at the 3'-side. It can be hypothesized that when Ǵ binds to the abasic site that is flanked by 5'-A_G, purines might contribute to some staking with the spin label, but in the presence of $5^{\prime}-C_{-} U$, pyrimidines can be completely stacked with the spin label.

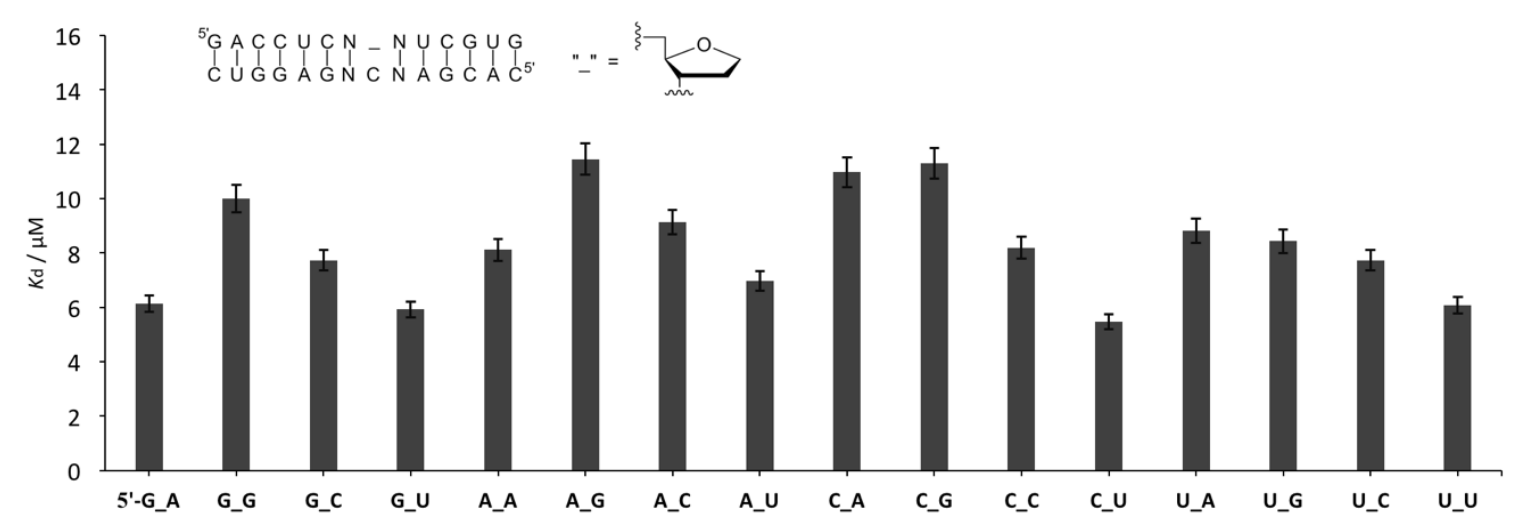

Figure 3.14 A plot of the dissociation constant of Ǵ-binding to duplex RNA containing an abasic site (denoted by "_") as a function of flanking sequence at $20{ }^{\circ} \mathrm{C}(200 \mu \mathrm{M}$ RNA duplex, $100 \mu \mathrm{M}$ Ǵ and a phosphate buffer, pH 7.0, containing 30\% ethylene glycol and 2\% DMSO).

\subsection{Distance measurements of Ǵ-labeled RNA duplexes by pulsed EPR spectroscopy}

Pulsed electron-electron double resonance (PELDOR, also called double electronelectron resonance or DEER) is a technique for precise and reliable distance measurements between two spin labels. ${ }^{[155]}$ This technique was used to measure the distances between two spin labels or nitroxide radicals that are attached to the biomolecules or nucleic acids at different sites of interests. In this technique, broad solid state EPR spectrum of a nitroxide is excited in two different parts (Figure 3.15A) using two microwave frequencies. 

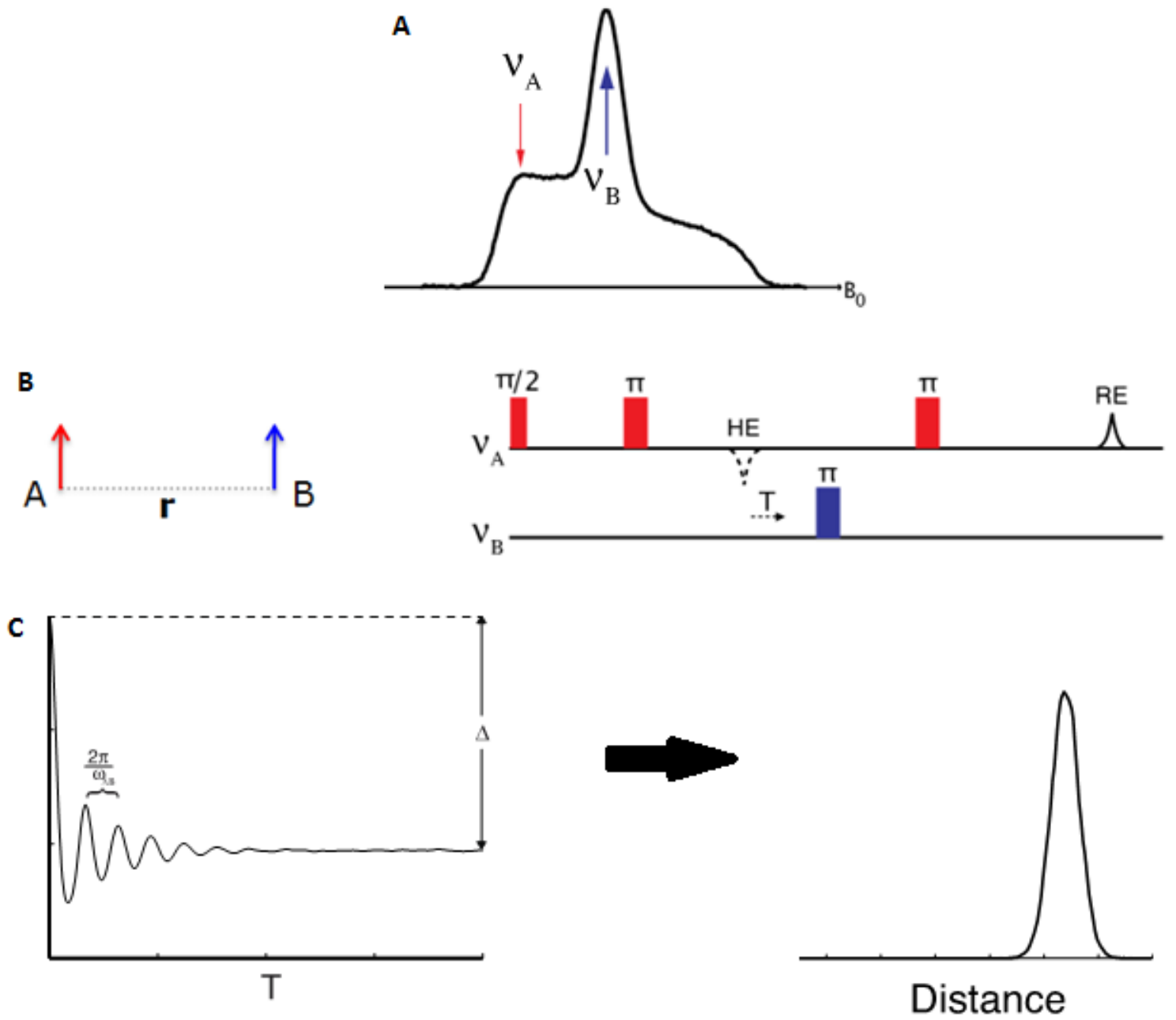

Figure 3.15 (A) Solid state EPR spectrum of a nitroxide radical. (B) Pulse sequence for a four-pulse PELDOR. A and B are the two spins separated by distance and $\boldsymbol{v}_{\mathrm{A}}$ and $\boldsymbol{\nu}_{\mathrm{B}}$ are detection and inversion frequencies respectively, $\mathbf{T}$ denotes the time position for the inversion pulse and $\Delta$ refers to modulation depth. (C) PELDOR time traces of a dipolar coupling. Distance obtained from the two spins A and B. (Figure courtesy: PhD thesis, Nitin Chhaban Kunjir, University of Iceland, 2014)

The two spin labels (A and B, Figure 3.15B, left) interact with each other via dipole-dipole coupling and are separated from each other by the inter-spin distance r. Usually a four-pulsed PELDOR sequence ${ }^{[156]}$ (Figure 3.15B, right) is used to perform the experiment. When a detection pulse sequence at a microwave frequency $v_{\mathrm{A}}$ is applied at which the spins that are in resonance with frequency $v_{\mathrm{A}}$ (Figure 3.15A, red arrow) a refocused echo (HE, Hahn-echo) is created. An inversion pulse with frequency $\nu_{B}$ is applied after time interval T, to invert the B spins, which are in resonance with frequency $\nu_{\mathrm{B}}$. This creates a modulation of the refocused echo (RE) of spin A due to the dipole-dipole coupling between spin A and B. Recording 
the refocused echo as a function of the time $\mathrm{T}$ gives a time trace that oscillates with the frequency of the dipole-dipole interaction (Figure 3.15C, right). The distance between the interacting spins A and B is obtained by Tikhonov regularization of the PELDOR time trace (Figure 3.15C, left). The interspin distance relies on the relationship between the dipolar frequency and the distance as shown in equation 2.

$$
v_{\text {dip }}=\frac{52.16}{r^{3}}\left(1-3 \cos ^{2} \theta\right) \quad \text { equation } 2
$$

where 52.16 is the dipolar splitting constant for two nitroxides, $\mathrm{r}$ is the magnitude of the inter-spin distance, $v_{\text {dip }}$ is the dipole frequency and $\theta$ is the angle between the interspin vector and the applied magnetic field.

\subsubsection{Distance measurement on a 22-mer RNA duplex}

To determine if noncovalent labeling could be used to measure interspin distances in RNA, a duplex RNA containing two abasic sites was constructed for PELDOR measurements (Figure 3.16). Before performing the PELDOR experiment, full binding of $\mathbf{G}$ to both the abasic sites was verified by CW-EPR spectroscopy. Full binding of $\mathbf{G}$ was observed at $-30{ }^{\circ} \mathrm{C}$ (Figure 3.16) and as the temperature was increased from $-20{ }^{\circ} \mathrm{C}$ to $20{ }^{\circ} \mathrm{C}$, the binding decreased. The extent of binding is noticeably less than for the 14-mer RNA duplex.

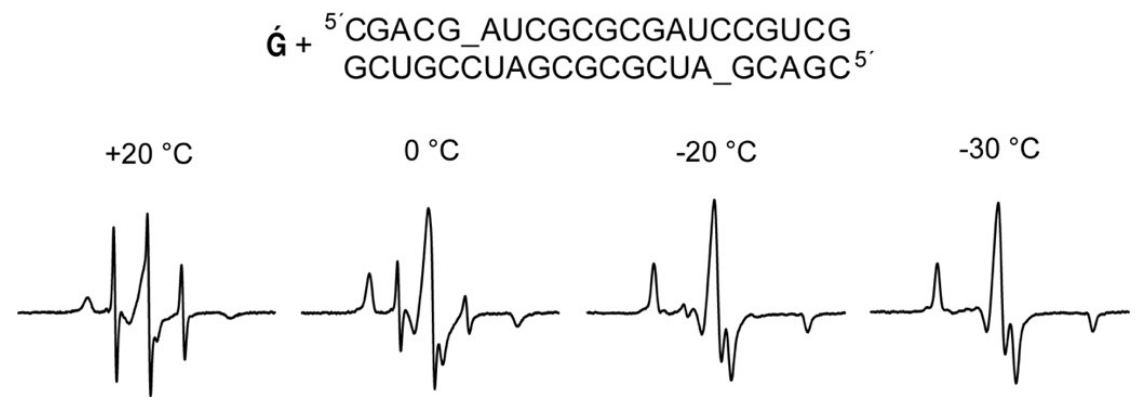

Figure 3.16 EPR spectra of Ǵ $(400 \mu \mathrm{M})$ in the presence of a 22-mer RNA duplex $(200 \mu \mathrm{M})$ containing two abasic sites, denoted as "_". EPR spectra were recorded in a phosphate buffer $\left(10 \mathrm{mM} \mathrm{Na}_{2} \mathrm{HPO}_{4}\right.$, $100 \mathrm{mM} \mathrm{NaCl}, 0.1 \mathrm{mM} \mathrm{Na}$ EDTA, pH 7.0) containing 30\% ethylene glycol and and 2\% DMSO. 
This study was carried out in collaboration with Prof. Thomas Prisner's laboratory at University of Goethe, Germany. The four-pulse PELDOR experiment was performed, in which a series of time-traces were collected as a function of the frequency offset (40-90 MHz) between the pump and probe pulses in steps of 10 $\mathrm{MHz}$ (Figure 3.17A). There was a striking variation in both the frequency and damping of the oscillations, consistent with strong orientation dependence. In other words, this experiment shows that there are not many different conformations of the spin label that are captured at the abasic site in RNA in frozen solution. Summing up the time traces and performing Tikhonov regularization gave a distance of $31.3 \pm 3.5 \AA$ (Figure 3.17B).
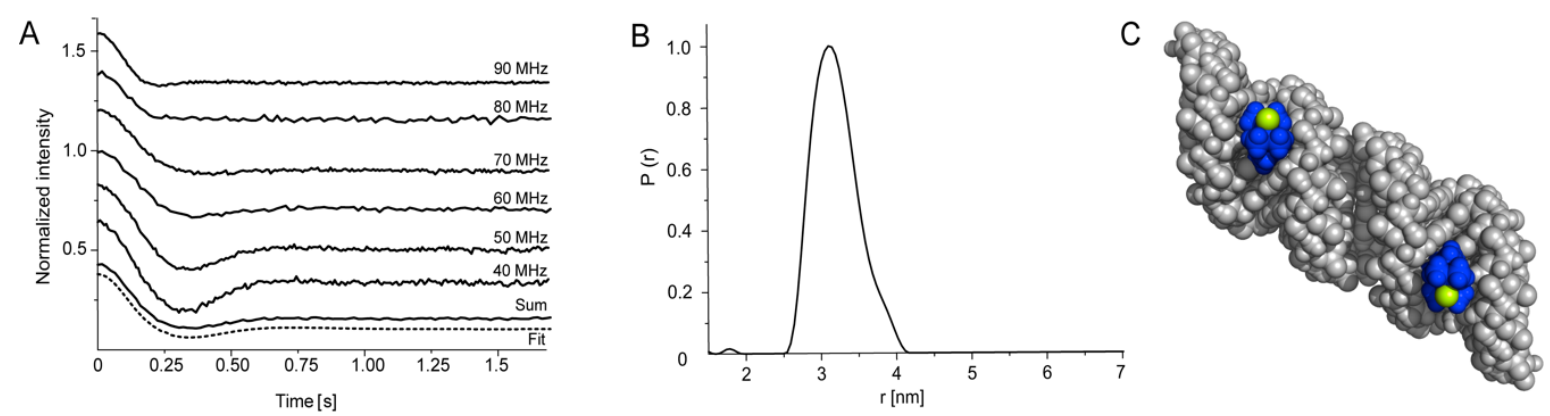

Figure 3.17 (A) Multi-frequency X-band $(9.4 \mathrm{GHz})$ PELDOR experiments after background correction performed at $50 \mathrm{~K}$. The lowest solid trace shows the sum of all the offset measurements, while the dotted trace shows the fit obtained with Tikhonov regularization. Traces have been shifted vertically for better visibility of individual traces. (B) The distance distribution of the summed PELDOR time traces, obtained with DeerAnalysis2013. (C) A model of two G's bound to the two abasic sites of the 22-mer RNA duplex.

Molecular modeling was carried out on an A-form RNA duplex in SPARTAN 10 (Wavefunction) using standard parameters. The abasic sites were generated by deleting the corresponding guanosine $(G)$ base. The spin label Ǵ was docked manually at the abasic sites so that it forms hydrogen bonds with the $C$ on the opposite strand. The modeled structures were exported as PDB files and visualized in PyMOL (Delano Scientific LCC) (Figure 3.18). Rotation of the bond between the isoindoline nitroxide and N2 of guanine in Ǵ, yielded several possible 
conformations due to possible rotation of the single bond connecting the isoindoline to amino group at $\mathrm{C} 2$ position of purine. Figure 3.18 shows three structures resulting from two orientations of each label parallel to minor groove of the RNA. The distances between the spin labels in these three structures were measured to be $26.4 \AA, 28.7 \AA$ and $31.1 \AA$, yielding an average distance of $28.7 \AA$, which is similar to the measured distance.
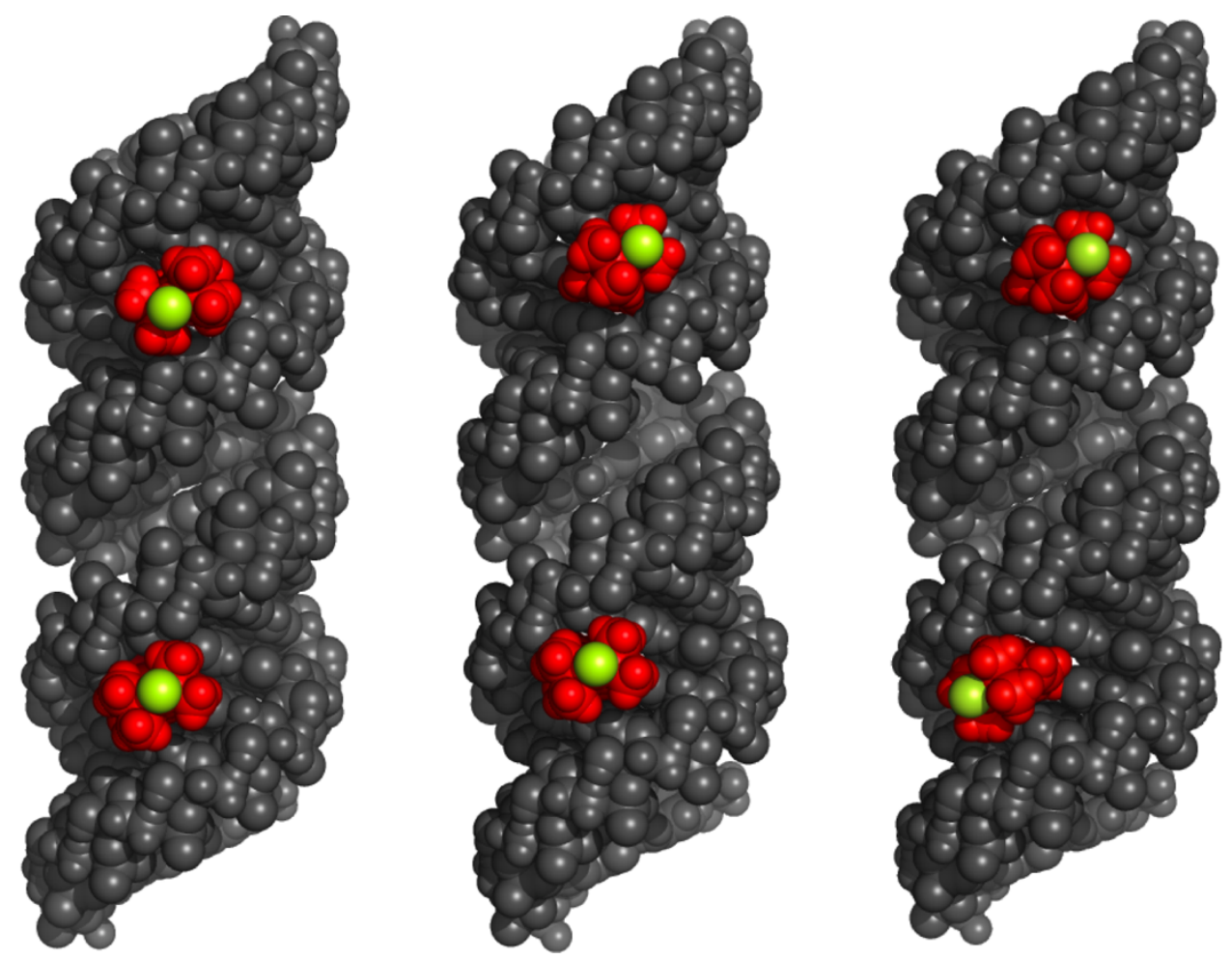

Figure 3.18 Molecular models of the noncovalently spin-labeled 22-mer RNA duplex in a spacefilling representation showing relative position of the two Ǵs (red). The oxygen atoms of the nitroxide functional groups are shown in green.

\subsection{Conclusion}

In summary, we have demonstrated that readily-synthesized purine-derived nitroxide spin labels can be used for noncovalent spin-labeling of abasic sites in nucleic acids duplexes, in particular RNA-RNA duplexes. Specifically, isoindolinederived spin labels 28, 30 and Ǵ are superior labels for noncovalent spin-labeling when compared to the TEMPO-derived spin labels 29,31 and 32 . The adenine 
derivative $\mathbf{2 8}$ and the guanine-nitroxide conjugate Ǵ bound efficiently to an abasic site of DNA duplexes and showed full binding to RNA duplexes. For all spin labels, the highest extent of binding was observed when the orphan base offered the possibility of Watson-Crick pairing, i.e. when the adenine derivatives bound to T (DNA) or U (RNA) and the guanine derivatives to $C$. This indicates that hydrogen bonding is a significant contributor to spin label binding. The adenine spin label 28 showed full binding to an abasic site of an RNA duplex opposite $U$ and complements Ǵ as a spin label, which pairs with C. It was also demonstrated that Ǵ binds efficiently to abasic sites of DNA-RNA hybrids. Only a minor flanking sequence effect was observed upon binding of Ǵ to abasic site in RNA-RNA duplexes. The spin label Ǵ should facilitate structural investigations of RNA by EPR spectroscopy due to the ease of spin labeling, as the label is simply added to a solution of the nucleic acid containing abasic sites. The PELDOR distance measurements showed a strong orientation dependence, indicating limited motion of Ǵ when bound to the RNA. This orientation dependence yields additional structural information, but the analysis will require more details of how Ǵ binds to the abasic site. Pulsed EPR, in conjunction with molecular dynamics experiments, is being used to investigate further the binding. 


\section{Binding of purine-derived spin labels to triplex-based DNA motifs}

\subsection{Introduction}

The first triple-helical nucleic acids were described by Felsenfeld et. al. 1957, who demonstrated that polyuridylic acid and polyadenylic acids strands in a 2:1 ratio were capable of forming a stable complex. ${ }^{[157]}$ In 1986, Moser and Dervan demonstrated intermolecular triple helix formation by site-specific binding of an oligonucleotide to the major groove of a DNA duplex. ${ }^{[158]}$ Several reports have proven that triplex-forming oligonucleotides can selectively control the expression of specific genes, which could be of value for the treatment of genetic disorders. ${ }^{[159-}$ 170]

Triple-helix formation occurs due to the presence of donor and acceptor groups in the major groove of a duplex DNA, that form Hoogsteen hydrogen bonds with bases in a triplex-forming oligonucleotide (TFO) (Figure 4.1A, red). Formation of triplexes require the presence of divalent metal ions, such as $\mathrm{Mg}^{2+}, \mathrm{Ca}^{2+}$ and $\mathrm{Zn}^{2+[157]}$ that presumably reduces the electrostatic repulsive forces between negatively charged phosphate backbones of the three strands. ${ }^{[171]}$ A TFO can either be a polypyrimidine or a polypurine molecule, binding to a purine-rich strand of a duplex DNA target site. In the pyrimidine motif, a TFO consists of either cytosine(C) or thymine- $(\mathrm{T})$ rich strand, that binds parallel to the purine-rich strand of DNA duplex via Hoogsteen bonds (Figure 4.1B). ${ }^{[158,172,173]}$ For proper Hoogsteen bonding with N7 of guanine, protonation at N3 of cytosine is required and occurs under acidic conditions. ${ }^{[174]}$ In the purine motif, an A on the third-strand binds to A:T, G binds to G:C and $\mathrm{T}$ binds to A:T base pairs (Figure 4.1C). ${ }^{[175,176]}$ The purine TFO 
(Figure 4.1C) binds antiparallel to the purine-rich strand in DNA via reverse Hoogsteen bonds without base protonation. ${ }^{[175]}$ A TFO may have considerable sequence selectivity to the duplex DNA but their binding is not strong. The stabilization of a triplex can be enhanced by using triplex-specific ligands like benzopyridoindoles and benzopyridoquinoxalines, ${ }^{[177-180]}$ that bind by intercalating into the triplex ${ }^{[180]}$ or by minor groove binding. ${ }^{[181,182]}$

A

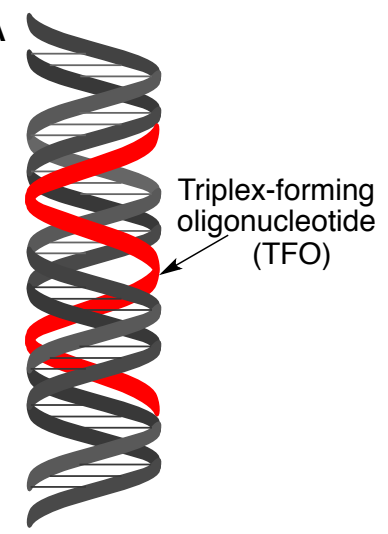

C

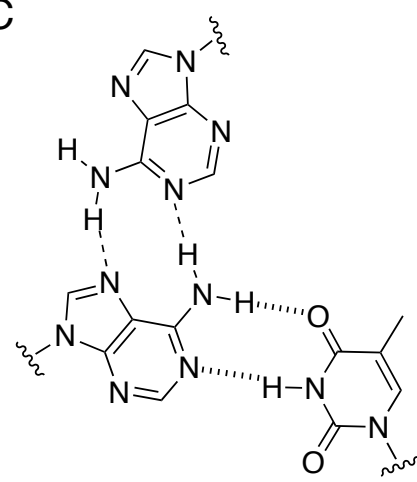

A.A:T

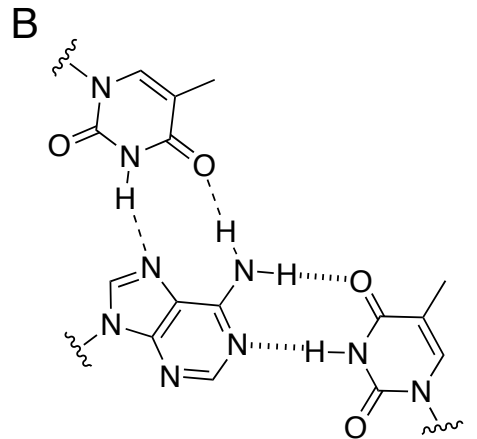

T.A:T

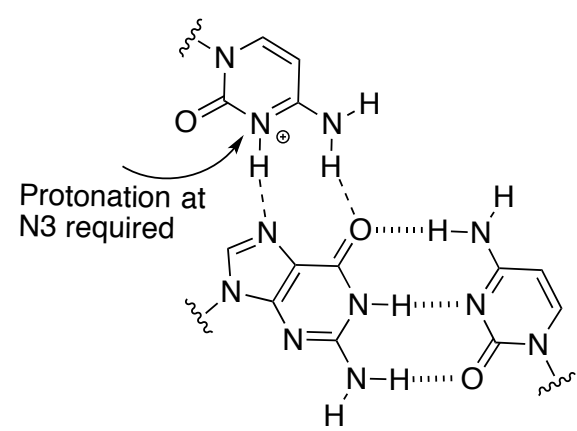

$C^{+} \cdot G: C$

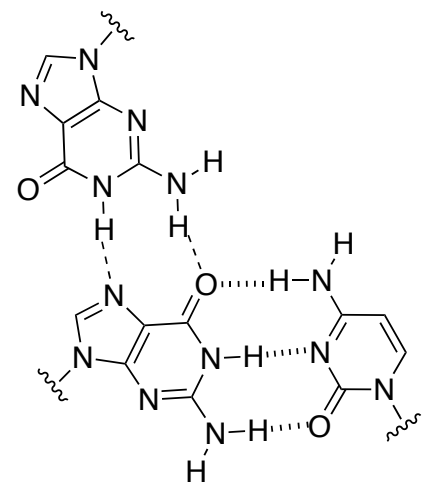

G.G:C

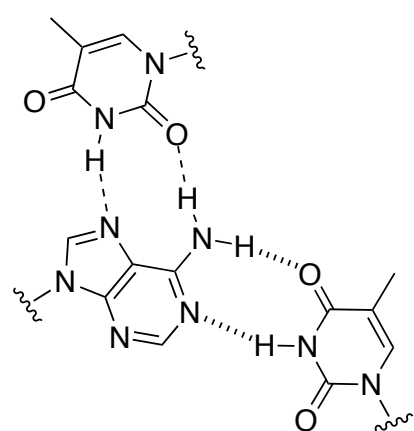

T:A:T

Figure 4.1 Basic structures of an oligonucleotide-based triple helix interaction. (A) A model showing the position of a TFO (red strand) in the major groove of DNA (gray). (B) The pyrimidine binding motif. From top: TFO binding in a parallel orientation to the purine strand of the DNA triplex. Protonation of N3 of cytosine in the $\mathrm{C}^{+}$.G:C triplex is required for proper hydrogen bonding to $\mathrm{G}$. (C) The purine binding motif. From top: TFO binding in antiparallel orientation to the purine strand of the DNA duplex. "---" represents Hoogsteen hydrogen bonds; “ hydrogen bonds.

Recently, Clemens et al. reported DNA triple helices that can be used for binding of cofactors. ${ }^{[183]}$ They developed DNA triple helices (Figure 4.2) containing a single nucleotide gap in the oligopurine strand to accommodate a nucleoside 
phosphate. ${ }^{[183-185]}$ Most cofactors contain ribonucleotides such as adenosine monoor diphosphate as recognition motifs. ${ }^{[186]}$ The DNA triplex VII binds tighter to deoxyadenosine monophosphate (dAMP) than the other adenosine phosphates, whereas motif VIII containing two nucleotide gaps showed more pronounced stabilization to cyclic adenosine monophosphate (cAMP). A four-strand construct of a triplex DNA helix with a seven nucleotide gap (Figure 4.2, IX) was also reported to bind seven nucleotides at a time. ${ }^{[183]}$ The binding of these nucleotides has been reported to be improved in the presence of $10 \mathrm{mM}$ phosphate buffer containing $1 \mathrm{M}$ $\mathrm{NaCl}$ and $80 \mathrm{mM} \mathrm{MgCl}$, which stabilizes the DNA triplex. ${ }^{[183]}$
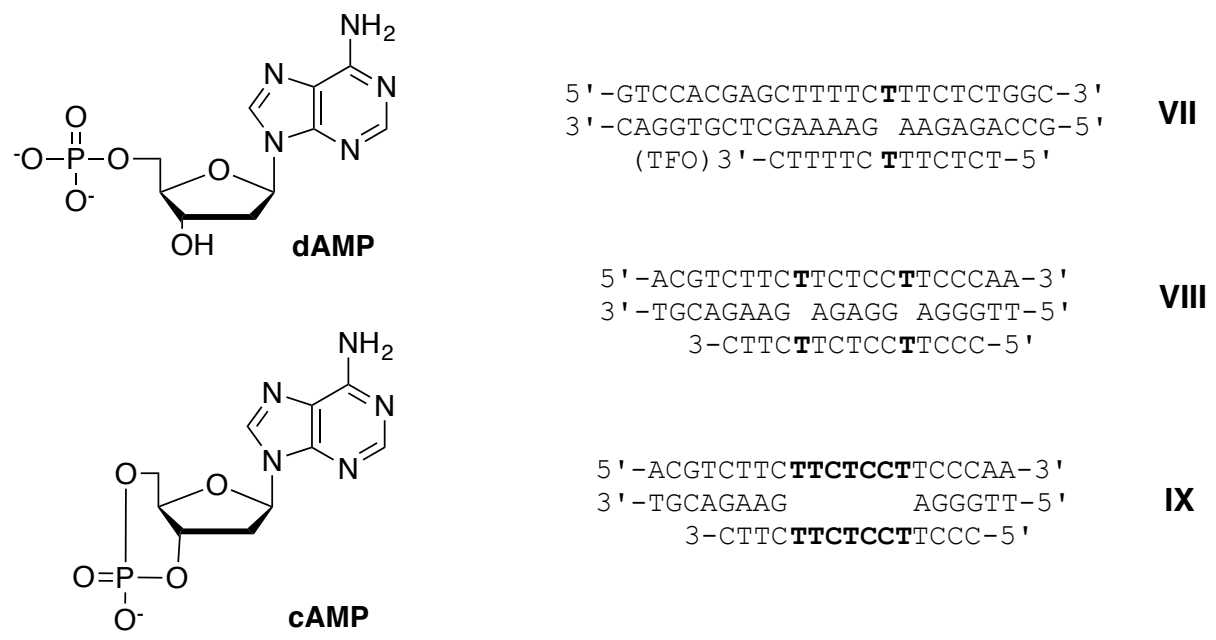

Figure 4.2 Structure of dAMP and cAMP (left). Four-strand based DNA triplex with a singlenucleotide gap (VII), two nucleotide gaps (VIII) and seven-nucleotide gaps (IX) (right).

We decided to investigate if these triplexes containing nucleotide gaps could be used to bind the spin labels that we had prepared for binding to abasic sites in nucleic acid duplexes. This project was pursued in collaboration with Prof. Clemens Richert's research group at University of Stuttgart, Germany who provided the triplex DNA motifs. To perform these experiments, we received three DNA motifs (Figure 4.3). Motif $X$ and XI are single-stranded intramolecular triplex folding that contain a single nucleotide gap, possessing the orphan bases $\mathrm{T}$ and $\mathrm{C}$, respectively (Figure 4.3B). The third DNA motif XII contained four individual DNA strands 
possessing a single nucleotide gap containing orphan bases $\mathrm{C}$ as shown in Figure 4.3B.

A<smiles></smiles>

28<smiles>CC1(C)CC(Nc2nc(N)nc3[nH]cnc23)CC(C)(C)N1O</smiles>

31<smiles>CC1(C)CC(Nc2ncnc3[nH]cnc23)CC(C)(C)N1O</smiles>

29<smiles></smiles>

32<smiles>CC1(C)c2ccc(Nc3nc(N)nc4[nH]cnc34)cc2C(C)(C)N1[O-]</smiles>

30

B

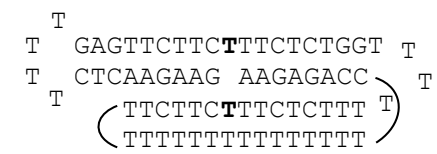

IV

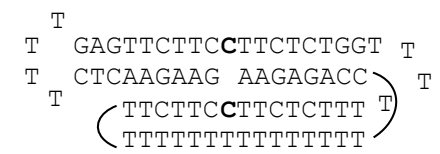

V<smiles>CC1(C)c2ccc(Nc3nc4[nH]cnc4c(=O)[nH]3)cc2C(C)(C)N1[O-]</smiles>

Ǵ

Figure 4.3 A. Structures of the purine-derived nitroxide spin labels. B. Structures of the DNA motifs.

\subsection{Results and Discussion}

\subsubsection{Binding of purine-derived spin labels to triplex-DNA}

The binding of the purine-derived spin labels to triplex-DNA was investigated by CW-EPR spectroscopy. As mentioned above, high concentration of monovalent salt $(\mathrm{NaCl})$, in addition to inclusion of divalent metal ions (e.g. $\left.\mathrm{Mg}^{2+}\right)$ stabilize the triplex helices. Clemens et al. used magnesium containing buffer (Breaker's binding buffer: $20 \mathrm{mM}$ Tris $\mathrm{HCl}, 450 \mathrm{mM} \mathrm{NaCl}, 100 \mathrm{mM} \mathrm{KCl}, 10 \mathrm{mM} \mathrm{MgCl}$, $1 \mathrm{mM} \mathrm{MnCl}$, $5 \mathrm{mM}$ $\left.\mathrm{CaCl}_{2}, \mathrm{pH} 6.7\right)^{[183]}$ for binding of cofactors to triplex-DNA. Therefore, we studied the binding affinities of these spin labels to the triplex-DNA using both our normal phosphate buffer and magnesium-containing buffer. The TEMPO-derived nitroxide spin labels $(29,31$ and 32$)$ showed very limited binding to the DNA motifs in both buffer solutions, whereas isoindoline-derived nitroxides Ǵ, 28 and $\mathbf{3 0}$ showed 
extensive or full binding. In the phosphate buffer, spin label 30 bound ca. $70 \%$ to triplex $\mathbf{X}$ and ca. $60 \%$ to XI (percentage of binding was calculated after double integration of the spectra), ${ }^{[132]}$ whereas Ǵ showed 55\% binding to both triplex DNAs XI and XII. Spin label 28 showed less binding (ca. 50\% to X) than Ǵ and 30. When these experiments were performed in magnesium containing buffer ( $\mathrm{pH}$ 6.7), the binding of Ǵ was improved significantly and bounds almost fully to XI and XII (ca. $>99 \%$ binding, black boxes). In contrast, a decrease in binding was observed for 28 (in X, ca. 30\%, black box) and 30 (in XI, ca. 30\% and XII, ca. 25\%, black boxes) in the presence of magnesium buffer. In addition, only marginal change in the binding of 28 (in XI and XII) and 30 (in X) was observed. This study reveals that, the presence of magnesium improves the binding of Ǵ. It was obvious that the spin labels 28-31 do not show improvement in binding, because N6-amino group is conjugated with the nitroxide-derivative that blocks base pairing with $\mathrm{T} / \mathrm{C}$ in the binding site of triplex-DNA. Ǵ and 32 are the nitroxide connected to the N2-position, which could be a more favorable position for triplex-DNA binding, because it should not affect the base pairing with Cs in the binding site of triplex-DNA. As expected we found Ǵ bound almost fully to triplex DNA in the presence of magnesium buffer. 

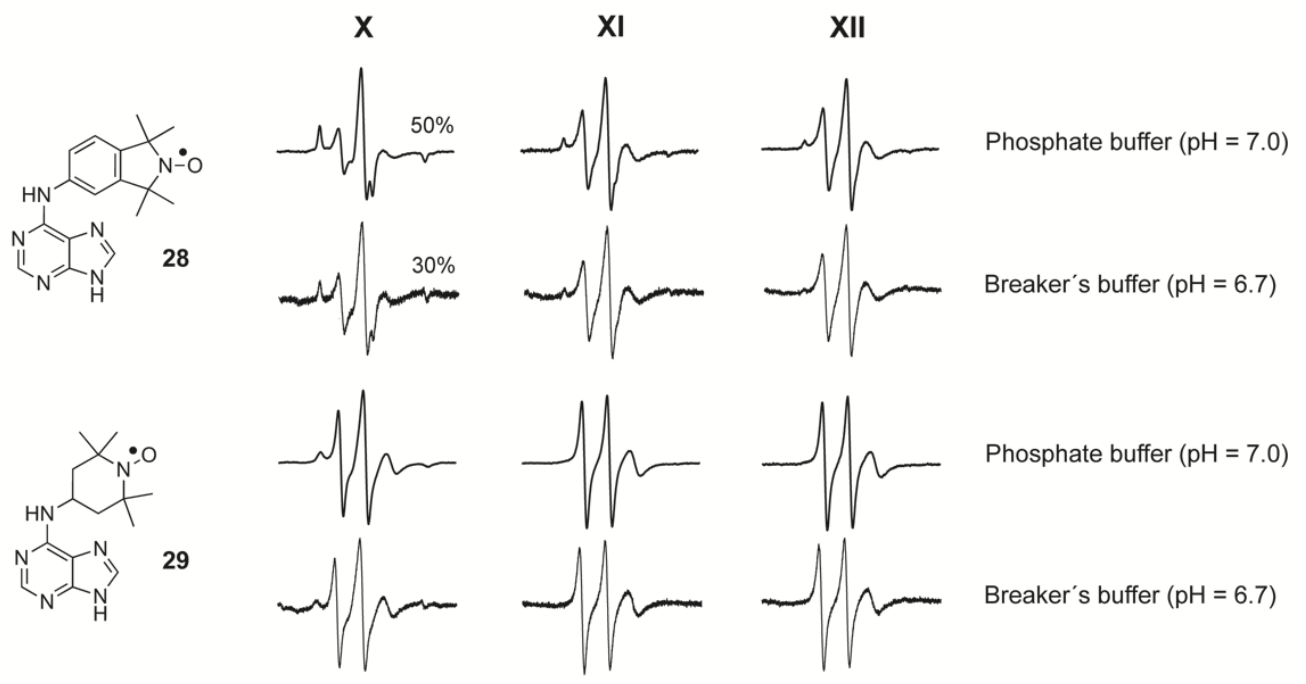

Phosphate buffer $(\mathrm{pH}=7.0)$<smiles>CN1C(C)(C)c2cc(Nc3nc(N)nc4nc[nH]c34)ccc2C(C)(C)C1(C)C</smiles><smiles>CCCCC(C)CC(C)C</smiles><smiles>CCCCC(C)CC(C)C</smiles>

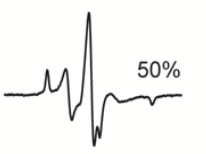
Phosphate buffer $(\mathrm{pH}=7.0)$

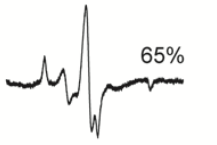<smiles>CCCCC(C)CCCC</smiles><smiles>CCCCC(C)CC(C)C</smiles>

Breaker's buffer $(\mathrm{pH}=6.7)$<smiles></smiles><smiles>C=C(C)C(C)=CC</smiles><smiles>CCC(C)C(C)CC</smiles><smiles>CCCCCCC</smiles>

Phosphate buffer $(\mathrm{pH}=7.0)$<smiles>CCCCC(C)CCC</smiles><smiles>CCC(C)C(C)CC</smiles><smiles>CCCCCCC</smiles>

Breaker's buffer $(\mathrm{pH}=6.7)$<smiles>CN1C(C)(C)CC(Nc2nc3[nH]cnc3c(=O)[nH]2)CC1(C)C</smiles><smiles>CCC(C)C1(CC)C(C)CCC1CC</smiles><smiles>CCC1C(CC)C(CC)C1CC</smiles><smiles>CCCCC(CC)C(CC)CCC</smiles>
Phosphate buffer $(\mathrm{pH}=7.0)$

Breaker's buffer $(\mathrm{pH}=6.7)$<smiles>CC(C)(C)N1C(C)(C)c2ccc(Nc3nc4[nH]cnc4c(=O)[nH]3)cc2C1(C)C</smiles>

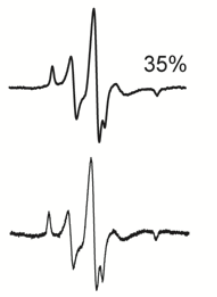

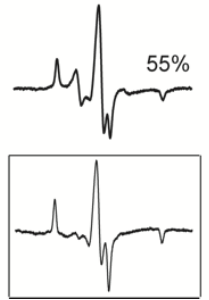

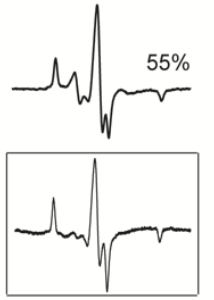

Phosphate buffer $(\mathrm{pH}=7.0)$

Breaker's buffer $(\mathrm{pH}=6.7)$

Figure 4.4 EPR spectra of spin labels Ǵ and 28-32 in the presence of DNA motifs X, XI and XII. EPR spectra inside the black boxes are showing the binding of Ǵ, 28 and $\mathbf{3 0}$ to triplex DNA, in which Ǵ bound almost fully to XI and XII, whereas binding of $\mathbf{2 8}$ and $\mathbf{3 0}$ was decreased as compared to phosphate buffer. Each of the spin labels $(200 \mu \mathrm{M})$ was incubated with each of the DNA motifs (400 $\mu \mathrm{M})$ and EPR spectra were recorded in a phosphate buffer $\left(10 \mathrm{mM} \mathrm{Na}_{2} \mathrm{HPO}_{4}, 100 \mathrm{mM} \mathrm{NaCl}, 0.1 \mathrm{mM}\right.$ Na2EDTA, pH 7.0) or Breaker's buffer (20 mM Tris HCl, $450 \mathrm{mM} \mathrm{NaCl}, 100 \mathrm{mM} \mathrm{KCl}, 10 \mathrm{mM} \mathrm{MgCl}$, $\left.1 \mathrm{mM} \mathrm{MnCl} 2,5 \mathrm{mM} \mathrm{CaCl}_{2}, \mathrm{pH} 6.7\right)^{[183]}$ containing 30\% ethylene glycol and $2 \%$ DMSO at $-30{ }^{\circ} \mathrm{C}$. 


\subsection{Conclusion}

Purine-derived TEMPO nitroxide spin labels (29, 31 and 32) showed very limited binding to the triplex DNAs X-XII in phosphate buffer, whereas Ǵ and $\mathbf{3 0}$ showed good binding (ca. $55 \%$ and $70 \%$, respectively). However, in the presence of a magnesium-containing buffer, no change in the binding was observed for 29, 31 and 32, whereas the binding of $\mathbf{2 8}$ in $\mathbf{X}$ and $\mathbf{3 0}$ in XI-XII was decreased as compared to phosphate buffer. The binding of Ǵ was slightly improved in $\mathbf{X}$, but Ǵ bound almost fully to both the triplex-DNA XI and XII. The nitroxide-derivative at N6-position (28-31) blocks one side of base pairing with T/C in triplex DNA, whereas nitroxide at N2-position is favorable (Ǵ) to form base pairs with both the Cs at binding site of the triplex-DNA (XI-XII). 


\section{Conclusion}

This thesis describes the further development of noncovalent attachment of spin labels to duplex nucleic acids, where a spin label binds to an abasic site forming Watson-Crick base pairing with the orphan base on the opposing strand and pistacking with the flaking bases. For the advancement of this approach, a series of purine-derived nitroxide spin labels was synthesized and the spin labels that have high binding efficiency to the abasic site of duplex nucleic acids were identified using EPR spectroscopy.

Isoindoline-derived spin labels 28, 30 and Ǵ were found to be much better spin labels than the TEMPO-derived spin labels 29, 31 and 32. Adenine derivative 28 and the guanine-nitroxide conjugate Ǵ bound efficiently to an abasic site of DNA duplexes and showed full binding to RNA duplexes. For all spin labels, the highest extent of binding was observed when the orphan base offered the possibility of forming Watson-Crick pairing, i.e. when the adenine-derivatives bound to T (DNA) or $\mathrm{U}$ (RNA) and the guanine-derivatives to $\mathrm{C}$. This indicated that Watson-Crick base pairing is a significant contributor to spin label binding. The spin label Ǵ was found to have the highest binding affinity to abasic sites in duplex RNA and using Ǵ we demonstrated for the first time noncovalent spin-labeling to abasic sites of DNARNA hybrids. Systematic variations of flanking sequences surrounding the abasic site of RNA duplex showed minimal effect on binding of Ǵ. It was also determined that the abasic site needs to be at the fourth position from the duplex end to achieve the same extent of binding as when the abasic site is located at the center of the RNA duplex. Moreover, Ǵ was shown to bind almost fully to triplex-DNAs containing a one nucleotide gap opposite Cs at the binding site. 
The spin label Ǵ was used to measure inter-spin distances using PELDOR and the results showed a strong orientation dependence with limited motion of the spin label when bound to the RNA. This study was carried out in collaboration with Prof. Thomas Prisner's laboratory at the Goethe University of Frankfurt, Germany.

A limitation of this noncovalent spin-labeling method is that it is only applicable for nucleic acid duplexes and not for single-strands. However, this method is appealing in that the spin label can be simply mixed with the modified nucleic acids prior to EPR measurements without any purification which is often experienced during the covalent attachment approach. Our approach has given researchers an easy access to spin-labeled duplex nucleic acids for EPR studies. In particular, the spin label Ǵ has high affinity to abasic sites in duplex nucleic acids. Ǵ is the first noncovalent spin label for RNA and and a highly promising candidate for the determination of structure of nucleic acids by PELDOR spectroscopy. 


\section{References}

1. Dahm R, Discovering DNA: Friedrich Miescher and the early years of nucleic acid research, Hum. Genet. 2008, 122, 565-581.

2. Miescher-Rüsch F Ueber die chemische Zusammensetzung der Eiterzellen, 1871.

3. Dahm R, Friedrich Miescher and the discovery of DNA, Dev. Biol. 2005, 278, 274-288.

4. Fischer E, Ber. Deut. chem. Ges., 1980, 17, 329.

5. Levene P, The structure of yeast nucleic acid, J. Biol. Chem. 1919, 609-621.

6. Levene P.A TRS, The partial synthesis of ribose nucleotides I. Uridine 5phosphoric acid, J. Biol. Chem. 1935, 111, 313-323.

7. Watson JD and Crick FH, Molecular structure of nucleic acids, Nature 1953, 171, 737-738.

8. Dorman JS, Schmella MJ and Wesmiller SW, Primer in genetics and genomics, article 1: DNA, genes, and chromosomes, Biol. Res. Nurs. 2017, 19, 7-17.

9. Crick F, Central dogma of molecular biology, Nature 1970, 227, 561-563.

10. Yusupova GZ, Yusupov MM, Cate J and Noller HF, The path of messenger RNA through the ribosome, Cell 2001, 106, 233-241.

11. Butler JE and Kadonaga JT, The RNA polymerase II core promoter: a key component in the regulation of gene expression, Genes Dev. 2002, 16, 2583-2592.

12. Valadkhan $S$, Role of the snRNAs in spliceosomal active site, RNA Biol. 2010, 7, 345-353.

13. Valadkhan $S$ and Gunawardane LS, Role of small nuclear RNAs in eukaryotic gene expression, Essays Biochem. 2013, 54, 79-90.

14. Higgs PG, RNA secondary structure: physical and computational aspects, $Q$. Rev. Biophys. 2000, 33, 199-253.

15. Winkler WC, Cohen-Chalamish $S$ and Breaker RR, An mRNA structure that controls gene expression by binding FMN, Proc. Natl. Acad. Sci. 2002, 99, 1590815913.

16. Ellington $\mathrm{AD}$ and Szostak JW, In vitro selection of RNA molecules that bind specific ligands, Nature 1990, 346, 818-822.

17. Robertson DL and Joyce GF, Selection in vitro of an RNA enzyme that specifically cleaves single-stranded DNA, Nature 1990, 344, 467-468.

18. Tuerk C and Gold L, Systematic evolution of ligands by exponential enrichment: RNA ligands to bacteriophage T4 DNA polymerase, Science 1990, 249, 505-510. 
19. Agrawal N, Dasaradhi P, Mohmmed A, Malhotra P, Bhatnagar RK and Mukherjee SK, RNA interference: biology, mechanism, and applications, Microbiol. Mol. Biol. Rev. 2003, 67, 657-685.

20. Hamilton AJ and Baulcombe DC, A species of small antisense RNA in posttranscriptional gene silencing in plants, Science 1999, 286, 950-952.

21. Elbashir Sm HJ, Lendeckel W, Yalcin a, Weber K, Tuschl T., Duplexes of 21nucleotide RNAs mediate RNA interference in cultured mammalian cells, Nature 2001, 411, 494-498.

22. Calin GA and Croce CM, MicroRNA signatures in human cancers, Nature reviews. Cancer 2006, 6, 857-866.

23. Garzon R, Calin GA and Croce CM, MicroRNAs in cancer, Annu. Rev. Med. 2009, 60, 167-179.

24. Lanford RE, Hildebrandt-Eriksen ES, Petri A, Persson R, Lindow M, Munk ME, Kauppinen $S$ and Ørum $H$, Therapeutic silencing of microRNA-122 in primates with chronic hepatitis C virus infection, Science 2010, 327, 198-201.

25. Mollaie HR, Monavari SHR, Arabzadeh SaM, Shamsi-Shahrabadi M, Fazlalipour M and Afshar RM, RNAi and miRNA in viral infections and cancers, Asian Pac. J. Cancer Prev. 2013, 14, 7045-7056.

26. Holbrook SR, Structural principles from large RNAs, Annu. Rev. Biophys. 2008, $37,445-464$.

27. Ban N, Nissen P, Hansen J, Moore PB and Steitz TA, The complete atomic structure of the large ribosomal subunit at $2.4 \AA$ resolution, Science 2000, 289, 905-920.

28. Schluenzen F, Tocilj A, Zarivach R, Harms J, Gluehmann M, Janell D, Bashan A, Bartels H, Agmon I and Franceschi F, Structure of functionally activated small ribosomal subunit at $3.3 \AA$ resolution, Cell 2000, 102, 615-623.

29. Edwards TE, Klein DJ and Ferré-D'amaré AR, Riboswitches: small-molecule recognition by gene regulatory RNAs, Curr. Opin. Struct. Biol 2007, 17, 273-279.

30. Wüthrich K, NMR with Proteins and Nucleic Acids, Europhys. News 1986, 17, 11-13.

31. Kim S-G, Lin L-J and Reid BR, Determination of nucleic acid backbone conformation by proton NMR, Biochemistry 1992, 31, 3564-3574.

32. Latham MP, Brown DJ, Mccallum SA and Pardi A, NMR methods for studying the structure and dynamics of RNA, ChemBioChem 2005, 6, 1492-1505.

33. Scott LG and Hennig M, RNA structure determination by NMR, Bioinformatics: Data, Sequence Analysis and Evolution 2008, 29-61. 
34. Bermejo GA, Clore GM and Schwieters CD, Improving NMR structures of RNA, Structure 2016, 24, 806-815.

35. Haller A, Rieder U, Aigner M, Blanchard SC and Micura R, Conformational capture of the SAM-II riboswitch, Nat. Chem. Biol. 2011, 7, 393-400.

36. Iwahara J, Zweckstetter $\mathrm{M}$ and Clore GM, NMR structural and kinetic characterization of a homeodomain diffusing and hopping on nonspecific DNA, Proc. Natl. Acad. Sci. 2006, 103, 15062-15067.

37. Sripakdeevong P, Cevec M, Chang AT, Erat MC, Ziegeler M, Zhao Q, Fox GE, Gao X, Kennedy SD and Kierzek R, Structure determination of noncanonical RNA motifs guided by 1H NMR chemical shifts, Nat. Methods 2014, 11, 413416.

38. Huppler A, Nikstad LJ, Allmann AM, Brow DA and Butcher SE, Metal binding and base ionization in the U6 RNA intramolecular stem-loop structure, Nat. Struct. Mol. Biol. 2002, 9, 431-435.

39. Hammann C, Norman DG and Lilley DM, Dissection of the ion-induced folding of the hammerhead ribozyme using 19F NMR, Proc. Natl. Acad. Sci. 2001, 98, 5503-5508.

40. Kreutz C, Kählig H, Konrat R and Micura R, Ribose 2 '-F Labeling: A Simple Tool for the Characterization of RNA Secondary Structure Equilibria by $19 \mathrm{~F}$ NMR Spectroscopy, J. Am. Chem. Soc. 2005, 127, 11558-11559.

41. Hennig M, Scott LG, Sperling E, Bermel W and Williamson JR, Synthesis of 5fluoropyrimidine nucleotides as sensitive NMR probes of RNA structure, $J$. Am. Chem. Soc. 2007, 129, 14911-14921.

42. Barhate NB, Barhate RN, Cekan P, Drobny G and Sigurdsson ST, A nonafluoro nucleoside as a sensitive 19F NMR probe of nucleic acid conformation, Org. Lett. 2008, 10, 2745-2747.

43. Duss O, Lukavsky PJ and Allain FH-T In Isotope labeling in Biomolecular NMR; Springer: 2012, p 121-144.

44. Xu Y and Matthews S In Modern NMR Methodology; Springer: 2011, p 97-119.

45. Millar DP, Fluorescence studies of DNA and RNA structure and dynamics, Curr. Opin. Struct. Biol 1996, 6, 322-326.

46. Corry B, Jayatilaka D and Rigby P, A flexible approach to the calculation of resonance energy transfer efficiency between multiple donors and acceptors in complex geometries, Biophys. J. 2005, 89, 3822-3836.

47. Roy R, Hohng S and Ha T, A practical guide to single-molecule FRET, Nat. Methods 2008, 5, 507-516. 
48. Sahoo H, Förster resonance energy transfer-A spectroscopic nanoruler: Principle and applications, J. Photochem. Photobiol., C 2011, 12, 20-30.

49. Preus S and Wilhelmsson LM, Advances in Quantitative FRET-Based Methods for Studying Nucleic Acids, ChemBioChem 2012, 13, 1990-2001.

50. Lafontaine DA, Norman DG and Lilley DM, The global structure of the VS ribozyme, The EMBO journal 2002, 21, 2461-2471.

51. Greenleaf WJ, Woodside MT and Block SM, High-resolution, single-molecule measurements of biomolecular motion, Annu. Rev. Biophys. Biomol. Struct. 2007, 36, 171-190.

52. Dunkle JA and Cate JH, Ribosome structure and dynamics during translocation and termination, Annu. Rev. Biophys. Biophys. Chem. 2010, 39, $227-$ 244.

53. Bassi GS, Møllegaard N-E, Murchie AI, Von Kitzing E and Lilley DM, Ionic interactions and the global conformations of the hammerhead ribozyme, Nat. Struct. Mol. Biol. 1995, 2, 45-55.

54. Eriksson $\mathrm{M}$ and Nordén B, Linear and circular dichroism of drug-nucleic acid complexes, Methods Enzymol 2001, 340, 68-98.

55. Nishimura $Y$, Sequence dependent DNA conformations: Raman spectroscopic studies and a model of action of restriction enzymes, Adv. Biophys. 1985, 20, 5974.

56. Zavoisky E, Paramagnetic relaxation of liquid solutions for perpendicular fields, J. Phys. USSR 1945, 9, 211.

57. Lunsford JH, The role of surface-generated gas-phase radicals in catalysis, Langmuir 1989, 5, 12-16.

58. Kocherginsky $\mathrm{N}$ and Swartz HM Nitroxide spin labels: reactions in biology and chemistry; CRC Press, 1995.

59. Chen YX, Qian LF, Zhang W and Han B, Efficient Aerobic Oxidative Synthesis of 2-Substituted Benzoxazoles, Benzothiazoles, and Benzimidazoles Catalyzed by 4-Methoxy-TEMPO, Angew. Chem. Int. Ed. 2008, 47, 9330-9333.

60. Nicolas J, Guillaneuf Y, Lefay C, Bertin D, Gigmes D and Charleux B, Nitroxide-mediated polymerization, Prog. Polym. Sci. 2013, 38, 63-235.

61. Edwards TE, Okonogi TM, Robinson BH and Sigurdsson ST, Site-specific incorporation of nitroxide spin-labels into internal sites of the TAR RNA; structure-dependent dynamics of RNA by EPR spectroscopy, J. Am. Chem. Soc. 2001, 123, 1527-1528.

62. Sowa GZ and Qin PZ, Site-directed spin labeling studies on nucleic acid structure and dynamics, Prog. Nucleic Acid Res. Mol. Biol. 2008, 82, 147-197. 
63. Zhang X, Cekan P, Sigurdsson ST and Qin PZ, Studying RNA using sitedirected spin-labeling and continuous-wave electron paramagnetic resonance spectroscopy, Methods Enzymol 2009, 469, 303-328.

64. HöBartner C, Sicoli G, Wachowius F, Gophane DB and Sigurdsson ST, Synthesis and characterization of RNA containing a rigid and nonperturbing cytidine-derived spin label, J. Org. Chem. 2012, 77, 7749-7754.

65. Nguyen P and Qin P, Wiley Interdiscip. Rev, RNA 2012, 3, 62-72.

66. Gophane DB and Sigurdsson ST, Hydrogen-bonding controlled rigidity of an isoindoline-derived nitroxide spin label for nucleic acids, Chem. Commun. 2013, 49, 999-1001.

67. Macosko J, Pio M, Tinoco I and Shin Y-K, A novel 5' displacement spin-labeling technique for electron paramagnetic resonance spectroscopy of RNA, RNA 1999, 5, 1158-1166.

68. Kim N-K, Murali A and Derose VJ, A distance ruler for RNA using EPR and site-directed spin labeling, Chem. Biol. 2004, 11, 939-948.

69. Steinhoff H-J, Inter-and intra-molecular distances determined by EPR spectroscopy and site-directed spin labeling reveal protein-protein and protein-oligonucleotide interaction, Biol. Chem. 2004, 385, 913-920.

70. Milov A, Salikhov K and Shirov M, Application of the double resonance method to electron spin echo in a study of the spatial distribution of paramagnetic centers in solids, Sov. Phys. Solid State 1981, 23, 565-569.

71. Jeschke G, Distance measurements in the nanometer range by pulse EPR, ChemPhysChem 2002, 3, 927-932.

72. Schiemann $\mathrm{O}$ and Prisner TF, Long-range distance determinations in biomacromolecules by EPR spectroscopy, Q. Rev. Biophys. 2007, 40, 1-53.

73. Bode BE, Dastvan R and Prisner TF, Pulsed electron-electron double resonance (PELDOR) distance measurements in detergent micelles, J. Magn. Reson. 2011, 211, 11-17.

74. Jeschke G, DEER distance measurements on proteins, Annu. Rev. Phys. Chem. 2012, 63, 419-446.

75. Duss O, Yulikov M, Jeschke G and Allain FH, EPR-aided approach for solution structure determination of large RNAs or protein-RNA complexes, Nat. Commun. 2014, 5, 3669.

76. Ottaviani MF, Ghatlia ND, Bossmann SH, Barton JK, Duerr H and Turro NJ, Nitroxide-labeled ruthenium (II)-polypyridyl complexes as EPR probes to study organized systems. 2. Combined photophysical and EPR investigations of B-DNA, J. Am. Chem. Soc. 1992, 114, 8946-8952. 
77. Qin PZ, Haworth IS, Cai Q, Kusnetzow AK, Grant GPG, Price EA, Sowa GZ, Popova A, Herreros B and $\mathrm{He} \mathrm{H}$, Measuring nanometer distances in nucleic acids using a sequence-independent nitroxide probe, Nat. Protoc. 2007, 2, 23542365.

78. Shelke SA and Sigurdsson ST; Springer: 2011, p 121-162.

79. Saha S, Jagtap AP and Sigurdsson ST, Site-Directed Spin Labeling of RNA by Postsynthetic Modification of 2'-Amino Groups, Methods Enzymol 2015, 563, 397-414.

80. Shelke SA and Sigurdsson ST, Site-Directed Spin Labelling of Nucleic Acids, Eur. J. Org. Chem. 2012, 2012, 2291-2301.

81. Berliner LJ and Reuben J Spin labeling: theory and applications; Springer 2012; Vol. 8.

82. Forrester A and Thomson R, Stable nitroxide radicals, Nature 1964, 203, 74-75.

83. Ohnishi S-I and Mcconnell HM, Interaction of the radical ion of chlorpromazine with deoxyribonucleic acid, J. Am. Chem. Soc. 1965, 87, 22932293.

84. Schiemann O, Fritscher J, Kisseleva N, Sigurdsson ST and Prisner TF, Structural Investigation of a High-Affinity MnII Binding Site in the Hammerhead Ribozyme by EPR Spectroscopy and DFT Calculations. Effects of Neomycin B on Metal-Ion Binding, ChemBioChem 2003, 4, 1057-1065.

85. Kisseleva N, Khvorova, Anastasia Westhof, Eric Schiemann, Olav Binding of manganese (II) to a tertiary stabilized hammerhead ribozyme as studied by electron paramagnetic resonance spectroscopy, RNA 2005, 11, 1-6.

86. Shelke SA and Sigurdsson ST In Modified Nucleic Acids; Springer: 2016, p 159187.

87. Haugland MM, Lovett JE and Anderson EA, Advances in the synthesis of nitroxide radicals for use in biomolecule spin labelling, Chem. Soc. Rev. 2018.

88. Matteucci MD and Caruthers M, Synthesis of deoxyoligonucleotides on a polymer support, J. Am. Chem. Soc. 1981, 103, 3185-3191.

89. Spaltenstein $\mathrm{A}$, Robinson $\mathrm{BH}$ and Hopkins $\mathrm{PB}, \mathrm{A}$ rigid and nonperturbing probe for duplex DNA motion, J. Am. Chem. Soc. 1988, 110, 1299-1301.

90. Fischhaber PL, Reese AW, Nguyen T, Kirchner JJ, Hustedt EJ, Robinson BH and Hopkins PB, Synthesis of Duplex DNA Containing a Spin Labeled Analog of 2' Deoxycytidine, Nucleosides Nucleotides 1997, 16, 365-377.

91. Schiemann O, Piton N, Mu Y, Stock G, Engels JW and Prisner TF, A PELDORbased nanometer distance ruler for oligonucleotides, J. Am. Chem. Soc. 2004, $126,5722-5729$. 
92. Piton N, Mu Y, Stock G, Prisner TF, Schiemann O and Engels JW, Base-specific spin-labeling of RNA for structure determination, Nucleic Acids Res. 2007, 35, 3128-3143.

93. Schiemann O, Piton N, Plackmeyer J, Bode BE, Prisner TF and Engels JW, Spin labeling of oligonucleotides with the nitroxide TPA and use of PELDOR, a pulse EPR method, to measure intramolecular distances, Nat Protoc 2007, 2, 904-923.

94. Krstic I, Frolow O, Sezer D, Endeward B, Weigand JE, Suess B, Engels JW and Prisner TF, PELDOR spectroscopy reveals preorganization of the neomycinresponsive riboswitch tertiary structure, J. Am. Chem. Soc. 2010, 132, 1454-1455.

95. Barhate N, Cekan P, Massey AP and Sigurdsson ST, A nucleoside that contains a rigid nitroxide spin label: a fluorophore in disguise, Angew. Chem. Int. Ed. 2007, 46, 2655-2658.

96. Cekan P, Smith AL, Barhate N, Robinson BH and Sigurdsson ST, Rigid spinlabeled nucleoside $\mathrm{C}$ : a nonperturbing EPR probe of nucleic acid conformation, Nucleic Acids Res. 2008, 36, 5946-5954.

97. Giotta GJ and Wang HH, Reduction of nitroxide free radicals by biological materials, Biochem. Biophys. Res. Commun. 1972, 46, 1576-1580.

98. Ramos A and Varani G, A new method to detect long-range protein-RNA contacts: NMR detection of electron-proton relaxation induced by nitroxide spin-labeled RNA, J. Am. Chem. Soc. 1998, 120, 10992-10993.

99. Macmillan AM and Verdine GL, Synthesis of functionally tethered oligodeoxynucleotides by the convertible nucleoside approach, J. Org. Chem. 1990, 55, 5931-5933.

100. Allerson CR, Chen SL and Verdine GL, A chemical method for site-specific modification of RNA: the convertible nucleoside approach, J. Am. Chem. Soc. 1997, 119, 7423-7433.

101. Budil DE, Kolaczkowski SV, Perry A, Varaprasad C, Johnson F and Strauss PR, Dynamics and ordering in a spin-labeled oligonucleotide observed by $220 \mathrm{GHz}$ electron paramagnetic resonance, Biophys. J. 2000, 78, 430-438.

102. Sicoli G, Wachowius F, Bennati M and Höbartner C, Probing secondary structures of spin-labeled RNA by pulsed EPR spectroscopy, Angew. Chem. Int. Ed. 2010, 49, 6443-6447.

103. Jakobsen U, Shelke SA, Vogel S and Sigurdsson ST, Site-directed spin-labeling of nucleic acids by click chemistry: detection of abasic sites in duplex DNA by EPR spectroscopy, J. Am. Chem. Soc. 2010, 132, 10424-10428. 
104. Ding P, Wunnicke D, Steinhoff HJ and Seela F, Site-Directed Spin-Labeling of DNA by the Azide-Alkyne 'Click'Reaction: Nanometer Distance Measurements on 7-Deaza-2'-deoxyadenosine and 2'-Deoxyuridine Nitroxide Conjugates Spatially Separated or Linked to a 'dA-dT'Base Pair, Chem. -Eur. J 2010, 16, 14385-14396.

105. Saha S, Jagtap AP and Sigurdsson ST, Site-directed spin labeling of 2'-amino groups in RNA with isoindoline nitroxides that are resistant to reduction, Chem. Commun. 2015, 51, 13142-13145.

106. Flaender M, Sicoli G, Fontecave T, Mathis G, Saint-Pierre C, Boulard Y, Gambarelli S and Gasparutto D In Nucleic Acids Symp. Ser.; Oxford University Press: 2008; Vol. 52, p 147-148.

107. Haugland MM, El-Sagheer AH, Porter RJ, Peña J, Brown T, Anderson EA and Lovett JE, 2'-Alkynylnucleotides: A sequence-and spin label-flexible strategy for EPR spectroscopy in DNA, J. Am. Chem. Soc. 2016, 138, 9069-9072.

108. Mccown PJ, Corbino KA, Stav S, Sherlock ME and Breaker RR, Riboswitch diversity and distribution, RNA 2017, 23, 995-1011.

109. Winkler WC and Breaker RR, Genetic control by metabolite-binding riboswitches, ChemBioChem 2003, 4, 1024-1032.

110. Blount KF and Breaker RR, Riboswitches as antibacterial drug targets, Nat. Biotechnol. 2006, 24, 1558-1564.

111. Denny W, DNA-intercalating ligands as anti-cancer drugs: prospects for future design, Anti-Cancer Drug Des. 1989, 4, 241-263.

112. D'incalci M and Sessa C, DNA minor groove binding ligands: a new class of anticancer agents, Expert Opin. Invest. Drugs 1997, 6, 875-884.

113. Monaco RR, A novel major groove binding site in B-form DNA for ethidium cation, J. Biomol. Struct. Dyn. 2007, 25, 119-125.

114. Hu W, Blecking C, Kralj M, Šuman L, Piantanida I and Schrader T, Dimeric Calixarenes: A New Family of Major-Groove Binders, Chem. -Eur. J 2012, 18, 3589-3597.

115. Almaqwashi AA, Paramanathan T, Rouzina I and Williams MC, Mechanisms of small molecule-DNA interactions probed by single-molecule force spectroscopy, Nucleic Acids Res. 2016, 44, 3971-3988.

116. Hong S-J and Piette LH, Electron spin resonance spin-label studies of intercalation of ethidium bromide and aromatic amine carcinogens in DNA, Cancer Res. 1976, 36, 1159-1171.

117. Sinha BK and Chignell CF, Acridine spin labels as probes for nucleic acids, Life Sci. 1975, 17, 1829-1836. 
118. Hong S-J and Piette L, Electron spin resonance spin label studies of intercalation of nitrobenzene in DNA, Arch. Biochem. Biophys. 1978, 185, $307-$ 315.

119. Atsumi H, Maekawa K, Nakazawa S, Shiomi D, Sato K, Kitagawa M, Takui T and Nakatani K, Noncovalent assembly of TEMPO radicals pair-wise embedded on a DNA duplex, Chem. Lett. 2010, 39, 556-557.

120. Atsumi H, Maekawa K, Nakazawa S, Shiomi D, Sato K, Kitagawa M, Takui T and Nakatani $\mathrm{K}$, Tandem arrays of TEMPO and nitronyl nitroxide radicals with designed arrangements on DNA, Chem. -Eur. J 2012, 18, 178-183.

121. Atsumi H, Nakazawa S, Dohno C, Sato K, Takui T and Nakatani K, Ligandinduced electron spin-assembly on a DNA tile, Chem. Commun. 2013, 49, 63706372.

122. Yoshimoto K, Nishizawa S, Minagawa M and Teramae N, Use of abasic sitecontaining DNA strands for nucleobase recognition in water, J. Am. Chem. Soc. 2003, 125, 8982-8983.

123. Yoshimoto K, Xu C-Y, Nishizawa S, Haga T, Satake H and Teramae N, Fluorescence detection of guanine-adenine transition by a hydrogen bond forming small compound, Chem. Commun. 2003, 2960-2961.

124. Sato Y, Nishizawa S, Yoshimoto K, Seino T, Ichihashi T, Morita K and Teramae $\mathrm{N}$, Influence of substituent modifications on the binding of 2-amino-1, 8naphthyridines to cytosine opposite an AP site in DNA duplexes: thermodynamic characterization, Nucleic Acids Res. 2009, 37, 1411-1422.

125. Thiagarajan V, Rajendran A, Satake H, Nishizawa S and Teramae N, NBDBased Green Fluorescent Ligands for Typing of Thymine-Related SNPs by Using an Abasic Site-Containing Probe DNA, ChemBioChem 2010, 11, 94-100.

126. Sato $Y$, Toriyabe $Y$, Nishizawa $S$ and Teramae N, 2, 4-Diamino-6, 7dimethylpteridine as a fluorescent ligand for binding and sensing an orphan cytosine in RNA duplexes, Chem. Commun. 2013, 49, 9983-9985.

127. Belmont P, Chapelle C, Demeunynck M, Michon J, Michon P and Lhomme J, Introduction of a nitroxide group on position 2 of 9-phenoxyacridine: easy access to spin labelled DNA-binding conjugates, Bioorg. Med. Chem. Lett. 1998, 8, 669-674.

128. Thomas F, Michon J and Lhomme J, Interaction of a spin-labeled adenineacridine conjugate with a DNA duplex containing an abasic site model, Biochemistry 1999, 38, 1930-1937.

129. Shelke SA and Sigurdsson ST, Noncovalent and site-directed spin labeling of nucleic acids, Angew. Chem. Int. Ed. 2010, 49, 7984-7986. 
130. Reginsson GW, Shelke SA, Rouillon C, White MF, Sigurdsson ST and Schiemann O, Protein-induced changes in DNA structure and dynamics observed with noncovalent site-directed spin labeling and PELDOR, Nucleic Acids Res. 2013, 41, e11.

131. Shelke SA, Sandholt GB and Sigurdsson ST, Nitroxide-labeled pyrimidines for non-covalent spin-labeling of abasic sites in DNA and RNA duplexes, Org. Biomol. Chem. 2014, 12, 7366-7374.

132. Shelke SA and Sigurdsson ST, Structural changes of an abasic site in duplex DNA affect noncovalent binding of the spin label c, Nucleic Acids Res. 2012, 40, 3732-3740.

133. Steklov MY, Tararov VI, Romanov GA and Mikhailov SN, Facile synthesis of 8-azido-6-benzylaminopurine, Nucleosides, Nucleotides Nucleic Acids 2011, 30, 503-511.

134. Reid D and Bottle $S$, The synthesis of water soluble isoindoline nitroxides and a pronitroxide hydroxylamine hydrochloride UV-VIS probe for free radicals, Chem. Commun. 1998, 1907-1908.

135. Gibson CL, La Rosa S and Suckling CJ, A prototype solid phase synthesis of pteridines and related heterocyclic compounds, Org. Biomol. Chem. 2003, 1, 1909-1918.

136. Hardcastle IR, Arris CE, Bentley J, Boyle FT, Chen Y, Curtin NJ, Endicott JA, Gibson AE, Golding BT and Griffin RJ, N2-substituted O 6cyclohexylmethylguanine derivatives: potent inhibitors of cyclin-dependent kinases 1 and 2, J. Med. Chem. 2004, 47, 3710-3722.

137. Zinchenko V, Application of the method of double integration to measure the quantity of paramagnetic centers, Meas.Tech. 1975, 18, 741-742.

138. Schick A and Rager H, Integration of EPR spectra, Appl. Magn. Reson. 1993, 4, 367-375.

139. Peracchi A, Beigelman L, Usman N and Herschlag D, Rescue of abasic hammerhead ribozymes by exogenous addition of specific bases, Proc. Natl. Acad. Sci.U.S.A. 1996, 93, 11522-11527.

140. Wyers F, Sentenac A and Fromageot P, Role of DNA-RNA Hybrids in Eukaryotes, Eur. J. Biochem. 1973, 35, 270-281.

141. Sidorenkov I, Komissarova N and Kashlev M, Crucial role of the RNA: DNA hybrid in the processivity of transcription, Mol. Cell 1998, 2, 55-64.

142. Zamaratski E, Pradeepkumar P and Chattopadhyaya J, A critical survey of the structure-function of the antisense oligo/RNA heteroduplex as substrate for RNase H, J. Biochem. Biophys. Methods 2001, 48, 189-208. 
143. Nowotny M, Gaidamakov SA, Crouch RJ and Yang W, Crystal structures of RNase $\mathrm{H}$ bound to an RNA/DNA hybrid: substrate specificity and metaldependent catalysis, Cell 2005, 121, 1005-1016.

144. Rich A, Discovery of the hybrid helix and the first DNA-RNA hybridization, J. Biol. Chem. 2006, 281, 7693-7696.

145. Ohle C, Tesorero R, Schermann G, Dobrev N, Sinning I and Fischer T, Transient RNA-DNA hybrids are required for efficient double-strand break repair, Cell 2016, 167, 1001-1013.

146. Aboul-Fadl T, Antisense oligonucleotides: the state of the art, Curr. Med. Chem. 2005, 12, 2193-2214.

147. Fedoroff OY, Salazar M and Reid BR, Structure of a DNA: RNA hybrid duplex: why RNase H does not cleave pure RNA, J. Mol. Biol. 1993, 233, 509-523.

148. Bachelin M, Hessler G, Kurz G, Hacia J, Dervan P and Kessler H, Structure of a stereoregular phosphorothioate DNA/RNA duplex, Nat. Struct. Biol. 1998, 5, 271-276.

149. Znosko BM, Barnes TW, Krugh TR and Turner DH, NMR Studies of DNA Single Strands and DNA: RNA Hybrids with and without 1-Propynylation at C5 of Oligopyrimidines, J. Am. Chem. Soc. 2003, 125, 6090-6097.

150. Conn GL, Brown T and Leonard GA, The crystal structure of the RNA/DNA hybrid r (GAAGAGAAGC) · (GCTTCTCTTC) shows significant differences to that found in solution, Nucleic Acids Res. 1999, 27, 555-561.

151. Xiong $\mathrm{Y}$ and Sundaralingam M, Crystal structure of a DNA. RNA hybrid duplex with a polypurine RNA $r$ (gaagaagag) and a complementary polypyrimidine DNA d (CTCTTCTTC), Nucleic Acids Res. 2000, 28, 2171-2176.

152. Kopka ML, Lavelle L, Han GW, Ng H-L and Dickerson RE, An unusual sugar conformation in the structure of an RNA/DNA decamer of the polypurine tract may affect recognition by RNase H, J. Mol. Biol. 2003, 334, 653-665.

153. Han GW, Kopka ML, Langs D, Sawaya MR and Dickerson RE, Crystal structure of an RNA. DNA hybrid reveals intermolecular intercalation: Dimer formation by base-pair swapping, Proc. Natl. Acad. Sci. U. S. A. 2003, 100, 92149219.

154. Andreatta D, Sen S, Pérez Lustres JL, Kovalenko SA, Ernsting NP, Murphy CJ, Coleman RS and Berg MA, Ultrafast Dynamics in DNA:"Fraying" at the End of the Helix, J. Am. Chem. Soc. 2006, 128, 6885-6892.

155. Jeschke G and Polyhach Y, Distance measurements on spin-labelled biomacromolecules by pulsed electron paramagnetic resonance, Phys. Chem. Chem. Phys. 2007, 9, 1895-1910. 
156. Martin RE, Pannier M, Diederich F, Gramlich V, Hubrich M and Spiess HW, Determination of End-to-End Distances in a Series of TEMPO Diradicals of up to $2.8 \mathrm{~nm}$ Length with a New Four-Pulse Double Electron Electron Resonance Experiment, Angew. Chem. Int. Ed. 1998, 37, 2833-2837.

157. Felsenfeld G, Davies DR and Rich A, Formation of a three-stranded polynucleotide molecule, J. Am. Chem. Soc. 1957, 79, 2023-2024.

158. Moser HE and Dervan PB, Sequence-specific cleavage of double helical DNA by triple helix formation, Science 1987, 238, 645-650.

159. Cooney M, Czernuszewicz G, Postel EH, Flint SJ and Hogan ME, Site-specific oligonucleotide binding represses transcription of the human c-myc gene in vitro, Science 1988, 241, 456-459.

160. Maher Iii LJ, Dervan PB and Wold B, Analysis of promoter-specific repression by triple-helical DNA complexes in a eukaryotic cell-free transcription system, Biochemistry 1992, 31, 70-81.

161. Maher Iii LJ, Dervan PB and Wold BJ, Kinetic analysis of oligodeoxyribonucleotide-directed triple-helix formation on DNA, Biochemistry 1990, 29, 8820-8826.

162. Durland RH, Kessler DJ, Gunnell S, Duvic M, Hogan ME and Pettitt B, Binding of triple helix forming oligonucleotides to sites in gene promoters, Biochemistry 1991, 30, 9246-9255.

163. Grigoriev M, Praseuth D, Robin P, Hemar A, Saison-Behmoaras T, DautryVarsat A, Thuong N, Helene C and Harel-Bellan A, A triple helix-forming oligonucleotide-intercalator conjugate acts as a transcriptional repressor via inhibition of NF kappa B binding to interleukin-2 receptor alpha-regulatory sequence, J. Biol. Chem. 1992, 267, 3389-3395.

164. Duval-Valentin G, Thuong NT and Helene C, Specific inhibition of transcription by triple helix-forming oligonucleotides, Proc. Natl. Acad. Sci. 1992, 89, 504-508.

165. Young SL, Krawczyk SH, Matteucci MD and Toole JJ, Triple helix formation inhibits transcription elongation in vitro, Proc. Natl. Acad. Sci. 1991, 88, 1002310026.

166. Jenjaroenpun $\mathrm{P}$, Chew CS, Yong TP, Choowongkomon K, Thammasorn $\mathrm{W}$ and Kuznetsov VA, The TTSMI database: a catalog of triplex target DNA sites associated with genes and regulatory elements in the human genome, Nucleic Acids Res. 2014, 43, D110-D116.

167. Duca M, Vekhoff P, Oussedik K, Halby L and Arimondo PB, The triple helix: 50 years later, the outcome, Nucleic Acids Res. 2008, 36, 5123-5138. 
168. Paquet J, Henrionnet C, Pinzano A, Vincourt J-B, Gillet P, Netter P, CharyValckenaere I, Loeuille D, Pourel J and Grossin L, Alternative for anti-TNF antibodies for arthritis treatment, Mol. Ther. 2011, 19, 1887-1895.

169. Mcneer NA, Chin JY, Schleifman EB, Fields RJ, Glazer PM and Saltzman WM, Nanoparticles deliver triplex-forming PNAs for site-specific genomic recombination in CD34+ human hematopoietic progenitors, Mole. Ther. 2011, 19, 172-180.

170. Trojan J, Pan YX, Wei MX, Ly A, Shevelev A, Bierwagen M, Ardourel M-Y, Trojan LA, Alvarez A and Andres C, Methodology for anti-gene anti-IGF-I therapy of malignant tumours, Chemother. Res. Pract. 2012, 2012.

171. Hampel KJ, Crosson P and Lee JS, Polyamines favor DNA triplex formation at neutral pH, Biochemistry 1991, 30, 4455-4459.

172. Letai AG, Palladino MA, Fromm E, Rizzo V and Fresco JR, Specificity in formation of triple-stranded nucleic acid helical complexes: studies with agarose-linked polyribonucleotide affinity columns, Biochemistry 1988, 27, 9108-9112.

173. François J-C, Saison-Behmoaras T and Hélène C, Sequence-specific recognition of the major groove of DNA by oligodeoxynucleotides via triple helix formation. Footprinting studies, Nucleic Acids Res. 1988, 16, 11431-11440.

174. Singleton SF and Dervan PB, Influence of $\mathrm{pH}$ on the equilibrium association constants for oligodeoxyribonucleotide-directed triple helix formation at single DNA sites, Biochemistry 1992, 31, 10995-11003.

175. Beal PA and Dervan PB, Second structural motif for recognition of DNA by oligonucleotide-directed triple-helix formation, Science 1991, 251, 1360-1363.

176. Postel E, Flint S, Kessler D and Hogan M, Evidence that a triplex-forming oligodeoxyribonucleotide binds to the c-myc promoter in HeLa cells, thereby reducing c-myc mRNA levels, Proc. Natl. Acad. Sci. 1991, 88, 8227-8231.

177. Escudé C, Sun J-S, Nguyen CH, Bisagni E, Garestier T and Hélène C, Ligandinduced formation of triple helices with antiparallel third strands containing G and T, Biochemistry 1996, 35, 5735-5740.

178. Escudé C, Nguyen CH, Kukreti S, Janin Y, Sun J-S, Bisagni E, Garestier T and Hélène $\mathrm{C}$, Rational design of a triple helix-specific intercalating ligand, Proc. Natl. Acad. Sci. 1998, 95, 3591-3596.

179. Hélène $C$ and Thuong NT, Control of gene expression by oligonucleotides covalently linked to intercalating agents, Genome 1989, 31, 413-421.

180. Silver GC, Nguyen CH, Boutorine AS, Bisagni E, Garestier T and Hélène C, Conjugates of oligonucleotides with triplex-specific intercalating agents. Stabilization of triple-helical DNA in the promoter region of the gene for the $\alpha$-subunit of interleukin 2 (IL-2R $\alpha$ ), Bioconjugate Chem. 1997, 8, 15-22. 
181. Robles J, Rajur SB and Mclaughlin LW, A parallel-stranded DNA triplex tethering a Hoechst 33258 analogue results in complex stabilization by simultaneous major groove and minor groove binding, J. Am. Chem. Soc. 1996, 118, 5820-5821.

182. Robles J and Mclaughlin LW, DNA triplex stabilization using a tethered minor groove binding Hoechst 33258 analogue, J. Am. Chem. Soc. 1997, 119, 6014-6021.

183. KröNer C, RöThlingshöFer $M$ and Richert C, Designed nucleotide binding motifs, J. Org. Chem. 2011, 76, 2933-2936.

184. Kröner C, Göckel A, Liu W and Richert C, Binding Cofactors with TriplexBased DNA Motifs, Chem. -Eur. J 2013, 19, 15879-15887.

185. Vollmer S and Richert C, DNA Triplexes That Bind Several Cofactor Molecules, Chem. -Eur. J 2015, 21, 18613-18622.

186. Voet D and Voet J, Rates of enzymatic reactions, Biochemistry, ed Stiefel J (Wiley, New York) 1990, 342-344. 


\section{Publications}

I. Nilesh R. Kamble, Markus Gränz, Thomas F. Prisner and Snorri Th. Sigurdsson; "Non-covalent site-directed spin labeling of duplex RNA", Chem. Commun., 2016, 52, 14442-14445

II. Nilesh R. Kamble, Snorri Th. Sigurdsson; "Purine-derived nitroxides for noncovalent spin-labeling of abasic sites in duplex nucleic acids", Chem. Eur. J., 2017, Just accepted.

III. Margret Thorsteinsdottir, Unnur A. Thorsteinsdottir, Finnur F. Eiriksson, Hrafnhildur L. Runolfsdottir, Inger M.Sch. Agustsdottir, Steinunn Oddsdottir, Baldur B. Sigurdsson, Hordur K. Hardarson, Nilesh R. Kamble, Snorri Th. Sigurdsson, Vidar O. Edvardsson, Runolfur Palsson; "Quantitative UPLC-MS/MS assay of urinary 2,8-dihydroxyadeine for diagnosis and management of adenine phosphoribosyltransferase deficiency", J. Chromatogr. B., 2016, 1036-1037, 170-177. 
Paper I 


\section{COMMUNICATION}

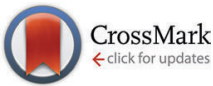

Cite this: Chem. Commun., 2016, 52,14442

Received 18th October 2016,

Accepted 23rd November 2016

DOI: $10.1039 / \mathrm{c} 6 \mathrm{cc} 08387 \mathrm{k}$

www.rsc.org/chemcomm

\section{Noncovalent and site-directed spin labeling of duplex RNA $\dagger$}

\author{
Nilesh R. Kamble, ${ }^{a}$ Markus Gränz, ${ }^{b}$ Thomas F. Prisner ${ }^{b}$ and Snorri Th. Sigurdsson*a
}

An isoindoline-nitroxide derivative of guanine (G, "G-spin") was shown to bind specifically and effectively to abasic sites in duplex RNAs. Distance measurements on a Ǵ-labeled duplex RNA with PELDOR (DEER) showed a strong orientation dependence. Thus, $G$ is a readily synthesized, orientation-selective spin label for " $\mathrm{mix}$ and measure" PELDOR experiments.

Electron paramagnetic resonance (EPR) spectroscopy is a magnetic resonance technique that has been used widely to investigate the structure and dynamics of biomolecules. ${ }^{1-7}$ Although widely applicable for such studies, EPR spectroscopy relies on the detection of unpaired electrons. With the exception of biomolecules that contain paramagnetic centers, such as metal ions, appendage of spin labels is usually required. Aminoxyl radicals, also called nitroxides, are commonly used for this purpose. Practical methods for incorporation of radicals should enable their attachment at specific sites, referred to as sitedirected spin labeling (SDSL), and have almost exclusively relied on linking radicals to the biomolecule through covalent bonds. $^{8-10}$ Covalent labeling can be performed either during the synthesis of the biopolymer or post-synthetically. Such labeling often requires extensive synthetic effort, can result in side-reactions and incomplete labeling and usually requires rather tedious purification of the spin-labeled biopolymer. ${ }^{11}$ Moreover, for RNA, there are only a few general spin-labeling methods available for labeling internal sites. ${ }^{12-18}$

A spin-labeling method that requires less effort, synthetic expertise and time is noncovalent labeling, in which the biopolymer could simply be mixed with the spin label prior to EPR measurements. There are examples of noncovalent labeling of biopolymers, but many of those spin labels have limited binding

\footnotetext{
${ }^{a}$ Department of Chemistry, Science Institute, University of Iceland, Dunhaga 3, 107 Reykjavik, Iceland. E-mail: snorrisi@hi.is

${ }^{b}$ Institute of Physical and Theoretical Chemistry and Center of Biomolecular Magnetic Resonance, Goethe University, Max-von-Laue-Str. 7, 60438 Frankfurt am Main, Hessen, Germany

$\dagger$ Electronic supplementary information (ESI) available. See DOI: 10.1039/c6cc08387k
}

affinity or specificity to the target molecule, such as nucleic acid intercalators. ${ }^{19-21}$ For proteins, efficient and specific binding has been demonstrated to native binding sites by attaching spin labels to cofactors ${ }^{10,22-26}$ or using encoded tags for high spin ions. ${ }^{27}$ However, these approaches are limited to a relatively few number of proteins and only certain site(s). Multiple spin labels have also been delivered to nucleic acids through binding of the $\mathrm{G}-\mathrm{G}$ mismatch-binding ligand naphthyridine carbamate dimer. $^{28,29}$

Abasic sites in duplex nucleic acids have been used as ligand binding-sites for noncovalent labeling. Examples include fluorescent compounds ${ }^{30-34}$ and adenine-acridine conjugates, some of which contain spin-labels. ${ }^{35}$ We have previously used abasic sites in duplex nucleic acids for site-directed labeling of nucleic acids. ${ }^{36-38}$ In particular, the spin label ç (Fig. 1), a derivative of cytosine, showed complete binding to abasic sites opposite to guanine in duplex DNAs at low temperatures. ${ }^{36}$ However, later studies revealed that only a few flanking sequences showed complete binding $^{39}$ and incorporation of two binding sites into the same duplex resulted in incomplete binding. ${ }^{40}$ In addition, only ca. $30 \%$ of ç was found to bind to abasic sites in RNA at low temperatures. ${ }^{38}$ Among several pyrimidine-derived nitroxides

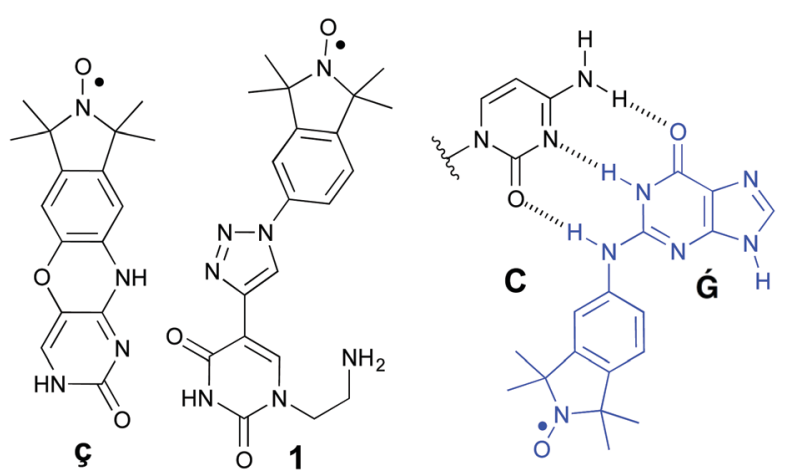

Fig. 1 Structure of the rigid spin label ç (left) and a triazole linkednitroxide spin label 1 (middle). Proposed base-pairing of spin label $\mathbf{G}$ (blue) with $\mathbf{C}$ at an abasic site in duplex RNA. 
that were subsequently prepared and screened for binding to both DNA and RNA, only the triazole-linked nitroxide 1 (Fig. 1), which contains an amino group for increased affinity, showed nearly complete binding to abasic sites in RNA. ${ }^{38}$ However, $\mathbf{1}$ was not a useful spin label because of its extensive non-specific binding to RNA.

Here we describe the synthesis and evaluation of the spin label '́ ("G-spin") for noncovalent binding to abasic sites in nucleic acid duplexes. This new spin label binds with high affinity and specificity to abasic sites in duplex RNA and shows extensive binding to abasic sites in duplex DNA. We also demonstrate the use of noncovalently labeled RNA for distance measurements by pulsed EPR spectroscopy. These experiments also show that the label has limited motion at the abasic site, as judged by a strong orientation dependence.

The new spin label $\mathbf{G}$ is an isoindoline derivative of guanine. In contrast to previously reported spin labels for noncovalent and site-directed labeling of nucleic acids that require multistep syntheses, ${ }^{36-38}$ '́ can be prepared in one step from readily available starting materials. The commercially available 2bromohypoxanthine was simply heated with isoindoline nitroxide $3^{41}$ in DMF to give Ǵ in moderate yield (Scheme 1).

The binding of '́ to abasic sites in nucleic acids at different temperatures was investigated using continuous wave (CW)-EPR spectroscopy (Fig. 2 and Fig. S2, ESI†). The spectrum of '́ in a phosphate buffer containing $30 \%$ ethylene glycol and $2 \%$ DMSO, showed a gradual broadening of the three narrow nitroxide lines as the temperature was lowered down to $-30^{\circ} \mathrm{C}$, due to decreased tumbling of the spin label in solution (Fig. 2A, left column). When the EPR spectrum of $\mathbf{G}$ was recorded for the same range of temperatures, in the presence of a DNA duplex containing an abasic site opposite to cytosine (C) (Fig. 2A, middle column), a slow-moving component started appearing in the spectrum at $10{ }^{\circ} \mathrm{C}$. This component increased as the temperature was lowered. At $-30{ }^{\circ} \mathrm{C}$, the EPR spectrum showed full binding of the spin label to the abasic site. When this experiment was performed in the presence of an RNA duplex, containing an abasic site (Fig. 2A, right column), there was extensive binding of the spin label, even at $20{ }^{\circ} \mathrm{C}\left(>95 \%, K_{\mathrm{D}}=6.15 \times 10^{-6} \mathrm{M}^{36}\right)$, at which temperature no binding to DNA was detected. At $-20{ }^{\circ} \mathrm{C}$, the spin label was fully bound to the abasic site in the RNA duplex. Thus, $\mathbf{G}$ has higher affinity to abasic sites in RNA duplexes than DNA duplexes. Changing the identity of the bases immediately flanking the abasic site of the RNA duplex (5'-A_U or 5'-C_U instead of $\left.5^{\prime}-\mathrm{G} \_\mathrm{A}\right)$ showed only a minor effect on the binding affinity to $\mathbf{G}$; the spin label was fully bound for all three sequences at $-30{ }^{\circ} \mathrm{C}$ (Fig. S3, ESI $\dagger$ ).

Since $\mathbf{G}$ binds to the nucleic acid through noncovalent interactions, it was important to verify that it was binding to

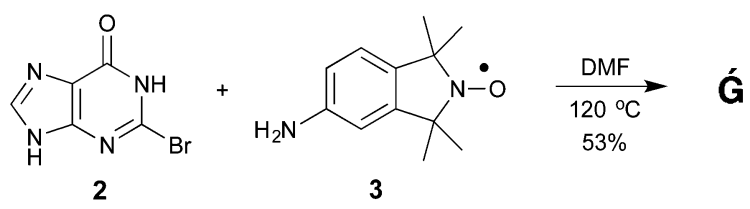

Scheme 1 Synthesis of the guanine-derived nitroxide spin label Ǵ.
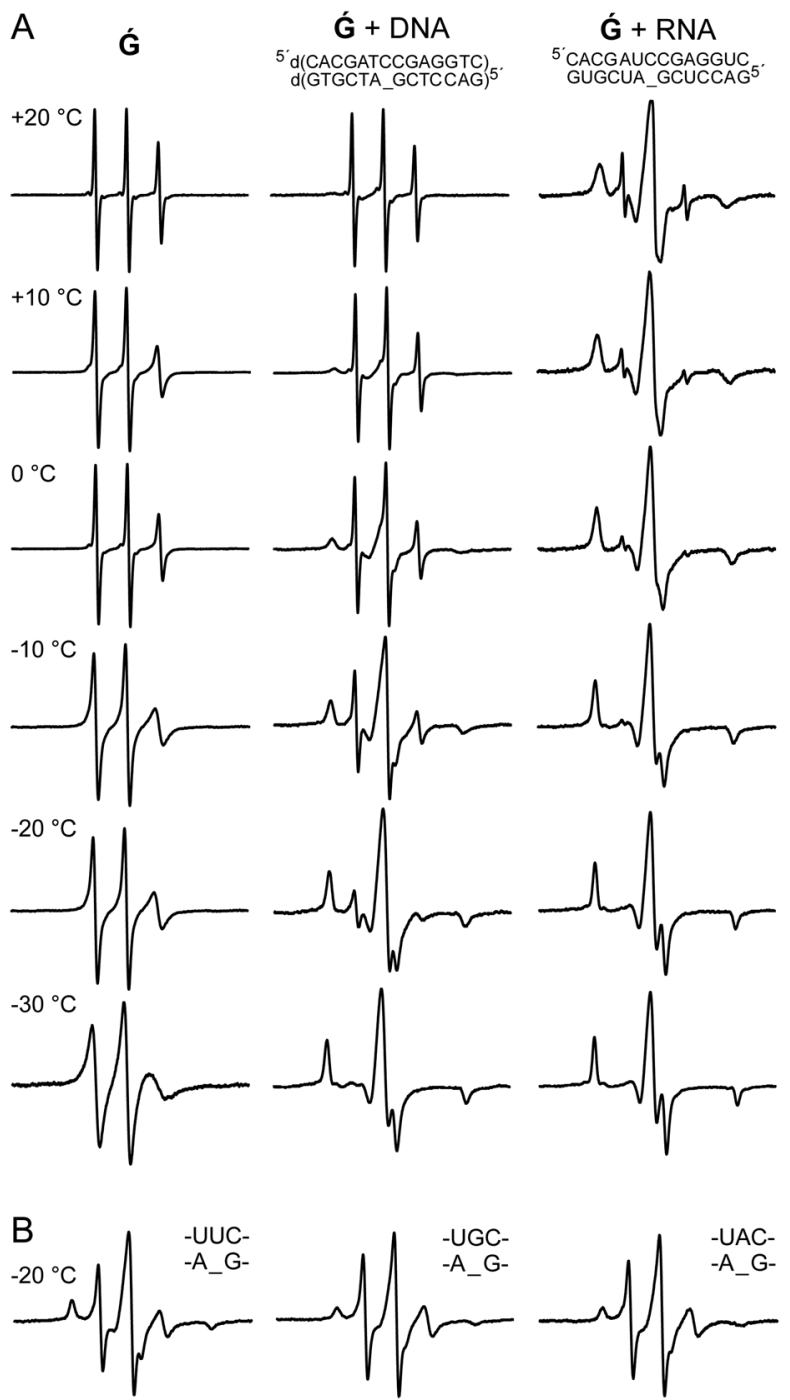

Fig. 2 (A) X-band CW-EPR spectra of the spin label Ǵ alone $(200 \mu \mathrm{M}$, left column), in the presence of abasic DNA ( $400 \mu \mathrm{M}$, middle column), and in the presence of abasic RNA ( $400 \mu \mathrm{M}$, right column). The temperature of each measurement is listed on the left. (B) CW-EPR spectra of $\dot{G}$ in presence of abasic RNAs containing non-complementary bases $(U, G$ and A) opposite to the abasic site, denoted by "-". All EPR spectra were recorded in a phosphate buffer $\left(10 \mathrm{mM} \mathrm{NaHPO}_{4}, 100 \mathrm{mM} \mathrm{NaCl}, 0.1 \mathrm{mM}\right.$ $\mathrm{Na}_{2}$ EDTA, pH 7.0) containing $30 \%$ ethylene glycol and $2 \%$ DMSO, using the same number of scans. The spectra were phase-corrected and aligned with respect to the height of the central peak.

the abasic site rather than non-specifically, for example by intercalation or groove binding. An unmodified RNA duplex that was mixed with one equivalent of spin label '́ showed barely detectable binding at $-20{ }^{\circ} \mathrm{C}(<1 \%$, Fig. S4, ESI $\dagger)$, which is the temperature required for full binding to the abasic site. Although slightly more non-specific binding was observed at $-30{ }^{\circ} \mathrm{C}(<5 \%)$, the small amount of binding at $-20{ }^{\circ} \mathrm{C}$, where the spin label is fully bound to the abasic site, will ensure a high occupancy of the labeling sites for distance measurements. Specific binding to the abasic site was also probed by titration with hypoxanthine, which has been used to rescue the activity of a hammerhead ribozyme containing an abasic site. ${ }^{42}$ 
Although hypoxanthine has lower affinity for the abasic site than $\mathbf{G}$, the spin label was clearly displaced from the duplex as the concentration of hypoxanthine was increased (Fig. S5, ESI $\dagger$ ).

To investigate the nature of the binding interactions between the spin label and the abasic site, binding of $\mathbf{G}$ to four RNA duplexes containing different orphan bases (A, U, G and C) on the strand opposite to the abasic site were investigated. Less binding was observed for the orphan bases A, G and U (Fig. 2B) than for $\mathrm{C}$, which showed full binding under these conditions (Fig. 2A). Slightly more binding was observed for $\mathrm{U}$ than for the two purines. The same trend was observed for DNA (Fig. S1, ESI $\dagger$ ). Taken together, these experiments indicate that $\mathbf{G}$ binds to the abasic site of both DNA and RNA duplexes by forming hydrogen bonds with the orphan base C.

Pulsed electron-electron double resonance (PELDOR, also called double electron-electron resonance or DEER) can be used to measure medium to long-range distances in RNA between two spin labels. ${ }^{1,4,5,7,43,44}$ To determine if noncovalent labeling could be used to measure interspin distances in RNA, a self-complementary 22-mer duplex containing two abasic sites was mixed with two equivalents of '́. CW-EPR spectroscopy showed $c a$. $80 \%$ binding of the spin label at $20{ }^{\circ} \mathrm{C}$ and full binding at $-30{ }^{\circ} \mathrm{C}$ (Fig. S6, ESI $\dagger$ ). A four-pulse PELDOR experiment ${ }^{45}$ was subsequently performed, in which a series of time-traces was collected as a function of the frequency offset (40-90 MHz) between the pump and probe pulses (Fig. 3B and Fig. S7, ESI $\dagger$ ). There was a striking variation in both the frequency and damping of the oscillations, consistent with strong orientation dependence. In other words, this experiment shows that there is very limited mobility of the spin label when bound to the abasic site in RNA. Summing up the time traces and performing Tikhonov regularization gave a distance of $31.3 \pm 3.5 \AA$ A similar to the distance of $c a$. $29 \AA$, based on simple modeling (Fig. 3C; see also ESI, $\dagger$ including Fig. S8).

The EPR data show that the spin label '́ binds with high enough affinity to enable PELDOR measurements on RNA. While it is true that this spin-labeling method is applicable for duplexes and not for single-strands, most functional RNA molecules contain two or more duplexes as structural scaffolds. Therefore, labeling duplex regions will provide valuable information about the tertiary structure and dynamics of such RNAs as well as conformational changes associated with binding to biomacromolecules or small-molecule ligands. ${ }^{46}$ The secondary structures of complex RNAs can be determined accurately, ${ }^{47}$ thereby identifying suitable labeling sites without any prior knowledge about the RNA tertiary structure. It should also be noted that this method is suitable for spin-labeling long RNAs ( $>100 \mathrm{nt}$ ); RNAs containing abasic sites can be readily synthesized using commercially available phosphoramidites or purchased directly from companies that provide custom synthesis of oligonucleotides. These modified RNAs can subsequently be ligated to other chemically synthesized RNAs, or RNAs prepared by transcription, using standard methods for RNA ligation. ${ }^{48,49}$

In conclusion, we have demonstrated that the nitroxide '́ prepared by a one-step synthesis from readily available starting materials, is an efficient spin label for noncovalent and site-directed
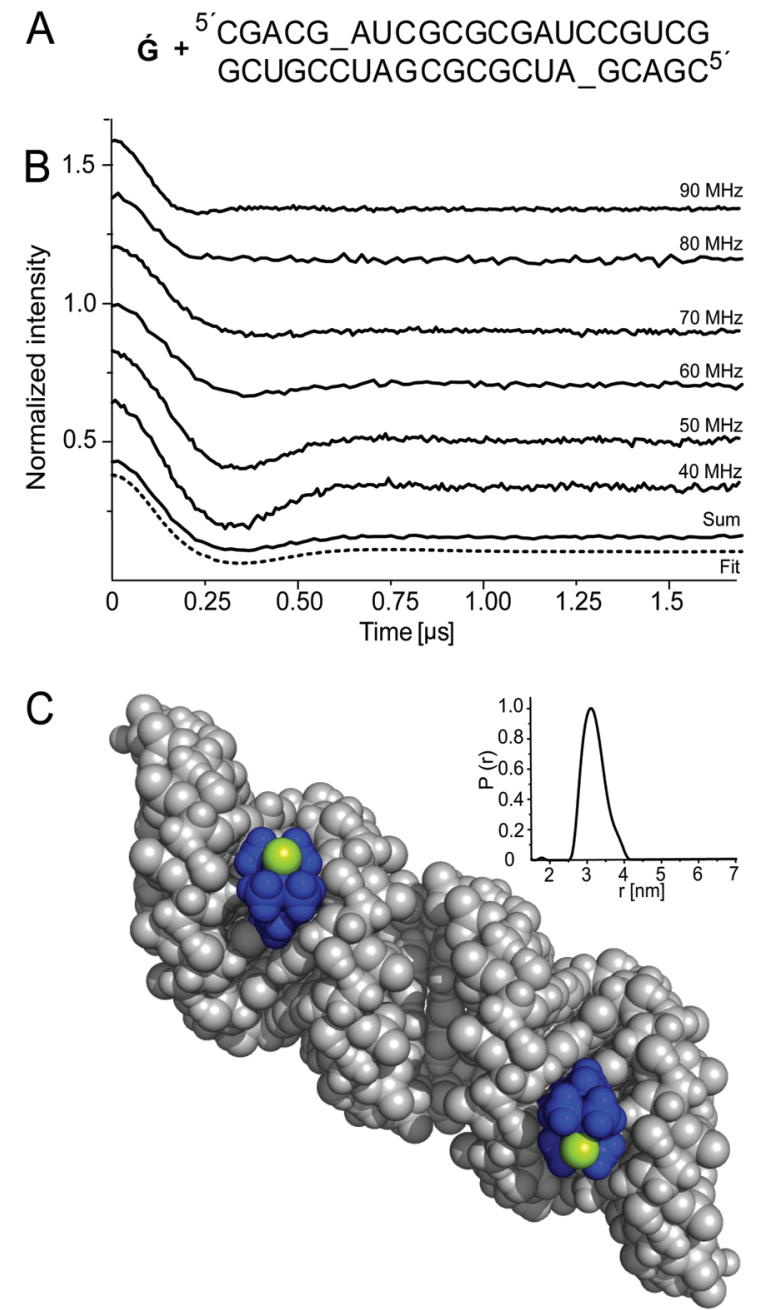

Fig. 3 (A) A 22-mer RNA duplex with two abasic sites, denoted as ".". (B) Multi-frequency X-band PELDOR experiments after background correction (original spectra are shown in Fig. S7, ESI†). The lowest solid trace shows the sum of all the offset measurements, while the dotted trace shows the fit obtained with Tikhonov regularization. Traces have been shifted vertically for better visibility of individual traces. (C) A model of two Ǵs bound to the two abasic sites of the 22-mer, along with the distance distribution of the summed PELDOR time traces (inset), obtained with DeerAnalysis $2013 .^{50}$

spin labeling of nucleic acids, in particular for RNA. The new spin label binds with specificity and unprecedented affinity to abasic sites of duplex RNA, where it appears to form hydrogen bonds to the orphan base. The spin label 'G should facilitate structural investigations of RNA by EPR spectroscopy due to the ease of spin labeling, as the label is simply added to a solution of the nucleic acid containing abasic sites. The PELDOR distance measurements also showed a strong orientation dependence, similar to that obtained with rigid spin labels. ${ }^{40}$ This orientation dependence yields additional structural information, but the analysis will require more details of how '́ binds to the abasic site. Those details are under investigation and will be reported in due course.

This work was supported by the Deutsche Forschungsgemeinschaft DFG (SFB 902 Molecular Principles of RNA-based 
Regulation), the Icelandic Research Fund (141062051) and by a doctoral fellowship to N. R. K. from the University of Iceland Research Fund. We thank Dr S. Jonsdottir for assistance in collecting analytical data for structural characterization of the compounds.

\section{Notes and references}

1 O. Schiemann and T. F. Prisner, Q. Rev. Biophys., 2007, 40, 1-53.

2 G. Z. Sowa and P. Z. Qin, Prog. Nucleic Acid Res. Mol. Biol., 2008, 82, 147-197.

3 L. Hunsicker-Wang, M. Vogt and V. J. Derose, Methods Enzymol., 2009, 468, 335-367.

4 X. Zhang, P. Cekan, S. T. Sigurdsson and P. Z. Qin, Methods Enzymol., 2009, 469, 303-328.

5 G. Jeschke, Annu. Rev. Phys. Chem., 2012, 63, 419-446.

6 Y. Ding, P. Nguyen, N. Tangprasertchai, C. Reyes, X. Zhang and P. Qin, Electron Paramagn. Reson., 2015, 24, 122-147.

7 T. F. Prisner, A. Marko and S. T. Sigurdsson, J. Magn. Reson., 2015, 252, 187-198.

8 W. L. Hubbell and C. Altenbach, Curr. Opin. Struct. Biol., 1994, 4, 566-573.

9 J. P. Klare and H.-J. Steinhoff, Photosynth. Res., 2009, 102, 377-390.

10 S. A. Shelke and S. T. Sigurdsson, Site-directed nitroxide spin labeling of biopolymers, Springer, 2011, pp. 121-162.

11 S. A. Shelke and S. T. Sigurdsson, Modified Nucleic Acids, Springer, 2016, pp. 159-187.

12 H. Hara, T. Horiuchi, M. Saneyoshi and S. Nishimura, Biochem. Biophys. Res. Commun., 1970, 38, 305-311.

13 T. E. Edwards, T. M. Okonogi, B. H. Robinson and S. T. Sigurdsson, J. Am. Chem. Soc., 2001, 123, 1527-1528.

14 N. Piton, Y. Mu, G. Stock, T. F. Prisner, O. Schiemann and J. W. Engels, Nucleic Acids Res., 2007, 35, 3128-3143.

15 G. Sicoli, F. Wachowius, M. Bennati and C. Höbartner, Angew. Chem., Int. Ed., 2010, 49, 6443-6447.

16 C. Höbartner, G. Sicoli, F. Wachowius, D. B. Gophane and S. T. Sigurdsson, J. Org. Chem., 2012, 77, 7749-7754.

17 S. Saha, A. P. Jagtap and S. T. Sigurdsson, Chem. Commun., 2015, 51, 13142-13145.

18 M. Kerzhner, D. Abdullin, J. Więcek, H. Matsuoka, G. Hagelueken, O. Schiemann and M. Famulok, Chem. - Eur. J., 2016, 22, 12113-12121.

19 S.-J. Hong and L. H. Piette, Cancer Res., 1976, 36, 1159-1171.

20 P. Belmont, C. Chapelle, M. Demeunynck, J. Michon, P. Michon and J. Lhomme, Bioorg. Med. Chem. Lett., 1998, 8, 669-674.

21 S. A. Shelke and S. T. Sigurdsson, Eur. J. Org. Chem., 2012, 2291-2301.

22 L. Stryer and O. H. Griffith, Proc. Natl. Acad. Sci. U. S. A., 1965, 54, 1785-1791.
23 A. S. Mildvan and H. Weiner, J. Biol. Chem., 1969, 244, 2465-2475.

24 G. C. Roberts, J. Hannah and O. Jardetzky, Science, 1969, 165, 504-506.

25 H. Weiner, Biochemistry, 1969, 8, 526-533.

26 A. Y. Misharin, O. Polyanovsky and V. Timofeev, Methods Enzymol., 1978, 62, 495-510.

27 D. Barthelmes, M. Gränz, K. Barthelmes, K. N. Allen, B. Imperiali, T. Prisner and H. Schwalbe, J. Biomol. NMR, 2015, 63, 275-282.

28 H. Atsumi, K. Maekawa, S. Nakazawa, D. Shiomi, K. Sato, M. Kitagawa, T. Takui and K. Nakatani, Chem. - Eur. J., 2012, 18, 178-183.

29 H. Atsumi, S. Nakazawa, C. Dohno, K. Sato, T. Takui and K. Nakatani, Chem. Commun., 2013, 49, 6370-6372.

30 K. Yoshimoto, S. Nishizawa, M. Minagawa and N. Teramae, J. Am. Chem. Soc., 2003, 125, 8982-8983.

31 K. Yoshimoto, C.-Y. Xu, S. Nishizawa, T. Haga, H. Satake and N. Teramae, Chem. Commun., 2003, 2960-2961.

32 Y. Sato, S. Nishizawa, K. Yoshimoto, T. Seino, T. Ichihashi, K. Morita and N. Teramae, Nucleic Acids Res., 2009, 37, 1411-1422.

33 V. Thiagarajan, A. Rajendran, H. Satake, S. Nishizawa and N. Teramae, ChemBioChem, 2010, 11, 94-100.

34 Y. Sato, Y. Toriyabe, S. Nishizawa and N. Teramae, Chem. Commun., 2013, 49, 9983-9985.

35 F. Thomas, J. Michon and J. Lhomme, Biochemistry, 1999, 38, 1930-1937.

36 S. A. Shelke and S. T. Sigurdsson, Angew. Chem., Int. Ed., 2010, 49, 7984-7986.

37 S. A. Shelke and S. T. Sigurdsson, ChemBioChem, 2012, 13, 684-690.

38 S. A. Shelke, G. B. Sandholt and S. T. Sigurdsson, Org. Biomol. Chem., 2014, 12, 7366-7374.

39 S. A. Shelke and S. T. Sigurdsson, Nucleic Acids Res., 2012, 40, 3732-3740.

40 G. W. Reginsson, S. A. Shelke, C. Rouillon, M. F. White, S. T. Sigurdsson and O. Schiemann, Nucleic Acids Res., 2013, 41, e11.

41 D. Reid and S. Bottle, Chem. Commun., 1998, 1907-1908.

42 A. Peracchi, L. Beigelman, N. Usman and D. Herschlag, Proc. Natl. Acad. Sci. U. S. A., 1996, 93, 11522-11527.

43 A. Milov, K. Salikhov and M. Shirov, Sov. Phys. Solid State, 1981, 23, 565-569.

44 A. Milov, A. Ponomarev and Y. D. Tsvetkov, Chem. Phys. Lett., 1984, 110, 67-72.

45 R. E. Martin, M. Pannier, F. Diederich, V. Gramlich, M. Hubrich and H. W. Spiess, Angew. Chem., Int. Ed., 1998, 37, 2833-2837.

46 C. M. Grytz, A. Marko, P. Cekan, S. T. Sigurdsson and T. F. Prisner, Phys. Chem. Chem. Phys., 2016, 18, 2993-3002.

47 J. T. Low and K. M. Weeks, Methods, 2010, 52, 150-158.

48 C. J. Kershaw and R. T. O'Keefe, Methods Protoc., 2012, 941, 257-269.

49 M. R. Stark and S. D. Rader, Methods Protoc., 2014, 1126, 137-149.

50 G. Jeschke, V. Chechik, P. Ionita, A. Godt, H. Zimmermann, J. Banham, C. Timmel, D. Hilger and H. Jung, Appl. Magn. Reson., 2006, 30, 473-498. 


\title{
Noncovalent and site-directed spin labeling of duplex RNA
}

\author{
Nilesh R. Kamble, ${ }^{1}$ Markus Gränz, ${ }^{2}$ Thomas F. Prisner ${ }^{2}$ and Snorri Th. Sigurdsson*1 \\ ${ }^{1}$ University of Iceland, Department of Chemistry, Science Institute, Dunhaga 3, 107 Reykjavik, Iceland. \\ ${ }^{2}$ Institute of Physical and Theoretical Chemistry and Center of Biomolecular Magnetic Resonance, Goethe \\ University, Max-von-Laue-Str. 7, 60438 Frankfurt am Main, Hessen, Germany
}

\section{Table of Contents}

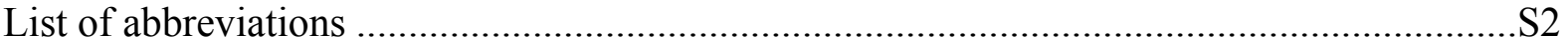

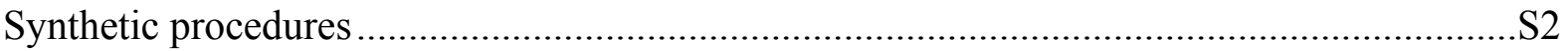

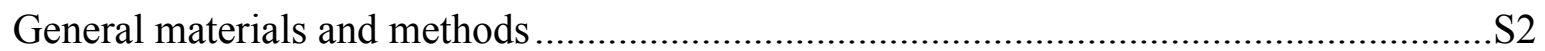

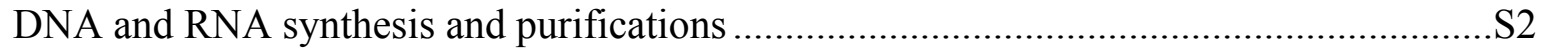

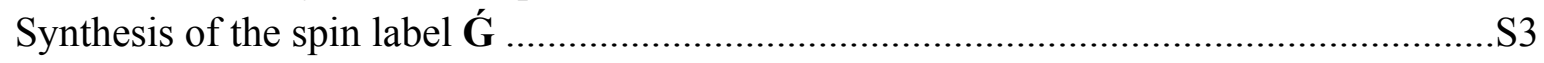

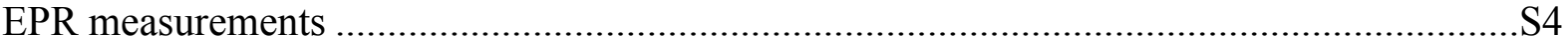

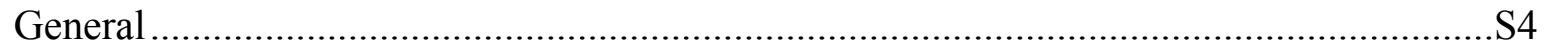

Effect of the identity of the orphan base on Ǵ-binding to an abasic site in a DNA duplex S5

Temperature dependence of $\mathbf{G}$-binding to an abasic site in duplex RNA ..........................S5

Effect of flanking sequence on noncovalent spin labeling of RNA with Ǵ. .....................S6

Determination of non-specific binding of $\mathbf{G}$ to an unmodified RNA duplex .....................S6

Distance measurements on a noncovalently labeled RNA duplex by PELDOR .................S7

Molecular modeling of $\mathbf{G}$ in the 22-mer RNA duplex containing two abasic sites................S8

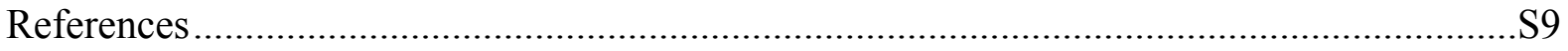




\section{List of abbreviations}

$\begin{array}{ll}\text { DMF } & N, N \text {-dimethylformamide } \\ \text { CW } & \text { continuous-wave } \\ \text { EPR } & \text { electron paramagnetic resonance } \\ \text { HRMS-ESI } & \text { high resolution mass spectrometry-electrospray ionization } \\ \text { NMR } & \text { nuclear magnetic resonance } \\ \text { A } & \text { adenine } \\ \text { C } & \text { cytosine } \\ \text { G } & \text { guanine } \\ \text { T } & \text { thymine } \\ \mathrm{U} & \text { uracil }\end{array}$

\section{Synthetic procedures}

\section{General materials and methods}

All reagents were purchased from commercial suppliers and were used without purification. Dichloromethane and acetonitrile were dried over calcium hydride and freshly distilled before use. Thin layer chromatography (TLC) was performed using glass plates pre-coated with silica gel (0.25 mm, F-25, Silicycle) and compounds were visualized by UV light. Column chromatography was performed using 230-400 mesh silica gel (Silicycle). ${ }^{1} \mathrm{H}$ NMR spectra were recorded with a Bruker Avance $400 \mathrm{MHz}$ spectrometer. Chemical shifts were reported in parts per million ( $\mathrm{ppm}$ ) relative to the partially deuterated NMR solvent $d_{6}$-DMSO (2.50 ppm). Nitroxide radicals show significant broadening in NMR spectra and loss of NMR signals due to their paramagnetic nature. ${ }^{1,2}$ Mass spectrometric analysis were performed on an HR-ESIMS (Bruker, MicroTOF-Q) in positive ion mode. All EPR data were recorded in a phosphate buffer (10 mM NaHPO $, 100 \mathrm{mM} \mathrm{NaCl}, 0.1 \mathrm{mM} \mathrm{Na} 2$ EDTA; pH 7) containing 30\% ethylene glycol and 2\% DMSO.

\section{DNA and RNA synthesis and purifications}

All commercial phosphoramidites, CPG columns, 5-benzylthiotetrazole and acetonitrile for oligomer synthesis were purchased from ChemGenes Corp., USA. All other required reagents and solvents were purchased from Sigma-Aldrich Co. Unmodified oligonucleotides and oligonucleotides containing abasic sites were synthesized on an automated ASM800 DNA synthesizer (Biosset, Russia) using a trityl-off protocol and commercially available phosphoramidites with standard protecting groups on $1.0 \mu$ mole scale (1000 $\AA$ CPG columns). The oligomers were deprotected in a 1:1 solution $(2 \mathrm{~mL})$ of $\mathrm{CH}_{3} \mathrm{NH}_{2}\left(8 \mathrm{M}\right.$ in EtOH) and $\mathrm{NH}_{3}$ $\left(33 \% \mathrm{w} / \mathrm{w}\right.$ in $\left.\mathrm{H}_{2} \mathrm{O}\right)$ at $65{ }^{\circ} \mathrm{C}$ for $45 \mathrm{~min}$. The solvent was removed in vacuo and the TBDMS- 
protecting groups were removed by incubation in $\mathrm{NEt}_{3}: 3 \mathrm{HF}(600 \mu \mathrm{L})$ for 90 min at $55{ }^{\circ} \mathrm{C}$ in DMF $(200 \mu \mathrm{L})$, followed by addition of water $(200 \mu \mathrm{L})$. The oligonucleotides were purified by $20 \%$ denaturing polyacrylamide gel electrophoresis. The oligonucleotides were visualized by UV light and the bands were excised from the gel, crushed and extracted from the gel matrix with a Tris buffer ( $250 \mathrm{mM} \mathrm{NaCl}, 10 \mathrm{mM}$ Tris, $1 \mathrm{mM} \mathrm{Na}_{2}$ EDTA, $\mathrm{pH}$ 7.5). The extracts were filtered through $0.45 \mu \mathrm{m}, 25 \mathrm{~mm}$ diameter GD/X syringe filters (Whatman, USA) and desalted using Sep-Pak cartridges (Waters, USA), according to the manufacturer's instructions. After removing the solvent in vacuo, the oligomers were dissolved in de-ionized and sterilized water $(200 \mu \mathrm{L})$. Oligonucleotides were quantified using Beer's law and measurements of absorbance at $260 \mathrm{~nm}$, using extinction coefficients determined by using the WinLab oligonucleotide calculator (V2.85.04, PerkinElmer).

\section{Synthesis of the spin label Ǵ}<smiles>O=c1[nH]c(Br)nc2[nH]cnc12</smiles>

2

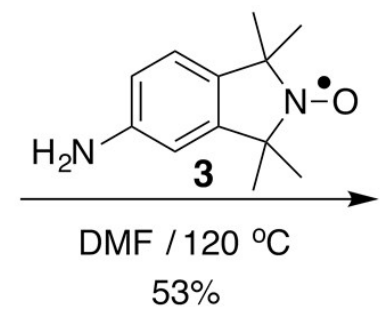

$53 \%$<smiles>CC1(C)c2ccc(Nc3nc4[nH]cnc4c(=O)[nH]3)cc2C(C)(C)[N+]1=O</smiles>

To a suspension of 2-bromo-6-hydroxypurine ${ }^{3}(200 \mathrm{mg}, 0.23 \mathrm{mmol})$ in DMF (5 mL) was added 1,1,3,3-tetramethylisoindoline-5-amino-2-oxyl ${ }^{4}(180 \mathrm{mg}, 0.25 \mathrm{mmol})$. The mixture was heated to $120^{\circ} \mathrm{C}$ for $12 \mathrm{~h}$. The solvent was evaporated in vacuo and the residue was purified by flash column chromatography using a solvent gradient $\left(0: 100\right.$ to $10: 90 \mathrm{MeOH}: \mathrm{CH}_{2} \mathrm{Cl}_{2}$, containing $2 \%$ of $\mathrm{NH}_{3}$ ) to give $\mathbf{G}$ as a yellow solid (167 mg, 53\%).

$\underline{{ }^{1} \mathrm{H} \text { NMR }\left(d_{6} \underline{\text {-DMSO}}\right):} \delta 1.69-1.72(\mathrm{bd}), 7.37(\mathrm{bs}), 7.75-8.00(\mathrm{bs}), 8.74(\mathrm{bs}), 10.62(\mathrm{bs}), 12.70$ (bs) ppm.

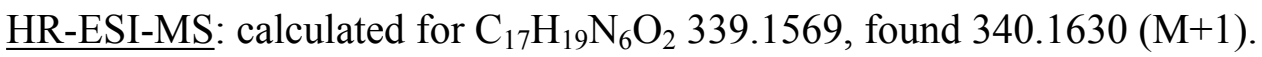




\section{EPR measurements}

\section{General}

Solutions for CW-EPR experiments were prepared by mixing aliquots of stock solutions of a single-stranded oligomer containing an abasic site, its complementary strand and the spin label Ǵ (1:1.2:0.5). The solvent was evaporated in vacuo and the resulting residue was dissolved in phosphate buffer $\left(10 \mu \mathrm{L} ; 10 \mathrm{mM} \mathrm{NaHPO}_{4}, 100 \mathrm{mM} \mathrm{NaCl}, 0.1 \mathrm{mM} \mathrm{Na}_{2}\right.$ EDTA, pH 7.0) and annealed: $90{ }^{\circ} \mathrm{C}$ for $2 \mathrm{~min}, 60^{\circ} \mathrm{C}$ for $5 \mathrm{~min}, 50{ }^{\circ} \mathrm{C}$ for $5 \mathrm{~min}, 22{ }^{\circ} \mathrm{C}$ for $15 \mathrm{~min}$ and dried using a SpeedVac. The residue was dissolved in an aqueous 30\% ethylene glycol solution $(10 \mu \mathrm{L})$ containing $2 \%$ DMSO and placed in a $50 \mu \mathrm{L}$ quartz capillary (BLAUBRAND intraMARK) (final concentration of nucleic acid duplex $200 \mu \mathrm{M}$ ). The EPR spectra were recorded using 100200 scans on a MiniScope MS200 (Magnettech Germany) spectrometer (100 kHz modulation frequency, $1.0 \mathrm{G}$ modulation amplitude and $2.0 \mathrm{~mW}$ microwave power). Magnettech temperature controller $\mathrm{M} 01\left( \pm 0.5^{\circ} \mathrm{C}\right)$ was used as temperature regulator.

For PELDOR measurements $20 \mu \mathrm{L}$ of sample volume with $80 \%$ buffer $/ 20 \%$ glycerol was transferred into $1.6 \mathrm{~mm}$ outer diameter quartz EPR tubes (Suprasil, Wilmad LabGlass). Pulsed EPR data were recorded on an ELEXSYS E580 EPR spectrometer (Bruker) equipped with a PELDOR unit (E580-400U, Bruker), a continuous-flow helium cryostat (CF935, Oxford Instruments) and a temperature control system (ITC 502, Oxford Instruments). X-band frequency $(9,4 \mathrm{GHz})$ experiments were performed at 50K with a BRUKER ER4118X-MS3 resonator and a $1 \mathrm{~kW}$ TWT amplifier. Pulse length were $32 \mathrm{~ns}(\pi / 2$ and $\pi)$ for the probe pulses and $12 \mathrm{~ns}$ for the pump inversion pulse. The frequency of the pump puls was set to the maximum of the nitroxide powder spectra and the detection frequency was changed between 40-90 MHz above, respectively. The delay time between the first two pulses of the primary echo sequence was varied between $132 \mathrm{~ns}$ and $196 \mathrm{~ns}$ in $8 \mathrm{~ns}$ steps in order to reduce ${ }^{1} \mathrm{H}$ nuclear modulation contributions to the PELDOR signal. For PELDOR experiments, the dead-time free four-pulse sequence with phase-cycled $\pi / 2$-pulses was used. ${ }^{5}$ Primary experimental data were background-corrected by fitting an exponential decay function for division of the intermolecular contribution. The resulting form factors $F(t)$ were fitted with a Tikhonov regularization to distance distributions with the DeerAnalysis2013 software package. ${ }^{6}$ 


\section{Effect of the identity of the orphan base on Ǵ-binding to an abasic site in a DNA duplex}

An evaluation of binding of $\mathbf{G}(200 \mu \mathrm{M})$ to an abasic site in four DNA duplexes $(400 \mu \mathrm{M})$, each of which contain different bases (A, T, G and C) opposite to the abasic site, was performed by recording the $\mathrm{CW}$-EPR spectra in $10 \mu \mathrm{L}$ phosphate buffer $\left(10 \mathrm{mM} \mathrm{NaHPO}_{4}, 100 \mathrm{mM} \mathrm{NaCl}\right.$, $0.1 \mathrm{mM} \mathrm{Na} 2$ EDTA, pH 7.0) containing $30 \%$ ethylene glycol and $2 \%$ DMSO at $-30{ }^{\circ} \mathrm{C}$. As expected, much less binding of $\mathbf{G}$ was observed for the orphan bases A, G and T, as compared to $\mathrm{C}$, which showed nearly full binding to the abasic site in the DNA duplex (Figure S1).

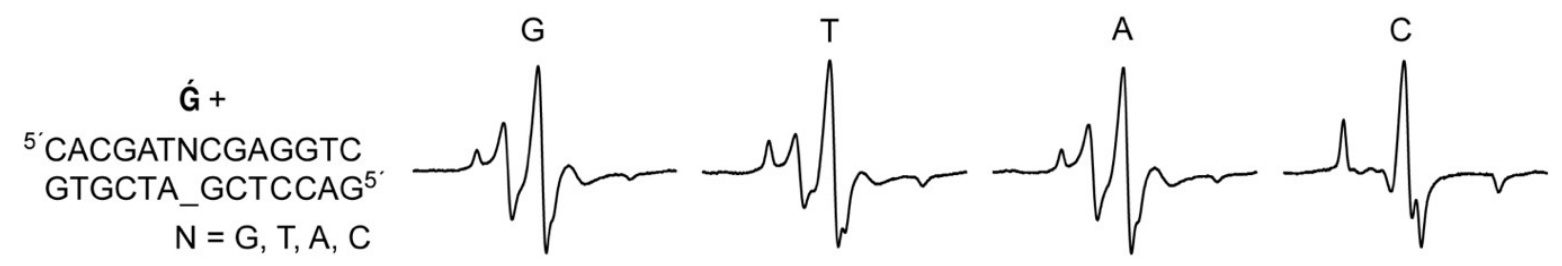

Figure S1. CW-EPR spectra of $\mathbf{G}$ in the presence of DNA duplexes containing abasic sites (“_") opposite to the four bases G, C, A and T. All EPR spectra were recorded using the same number of scans, phase corrected and aligned with respect to the height of the central peak.

\section{Temperature dependence of Ǵ-binding to an abasic site in duplex RNA}

CW-EPR spectra of a 14-mer RNA duplex, containing an abasic site, were recorded in the presence of $\mathbf{G}$ at different temperatures. Upon lowering the temperature, the amount of nonbound $\mathbf{G}$ decreased, as judged by the reduction of the fast-moving component of the spectrum (Figure S2). At $-20^{\circ} \mathrm{C}$, the spin label was fully bound.

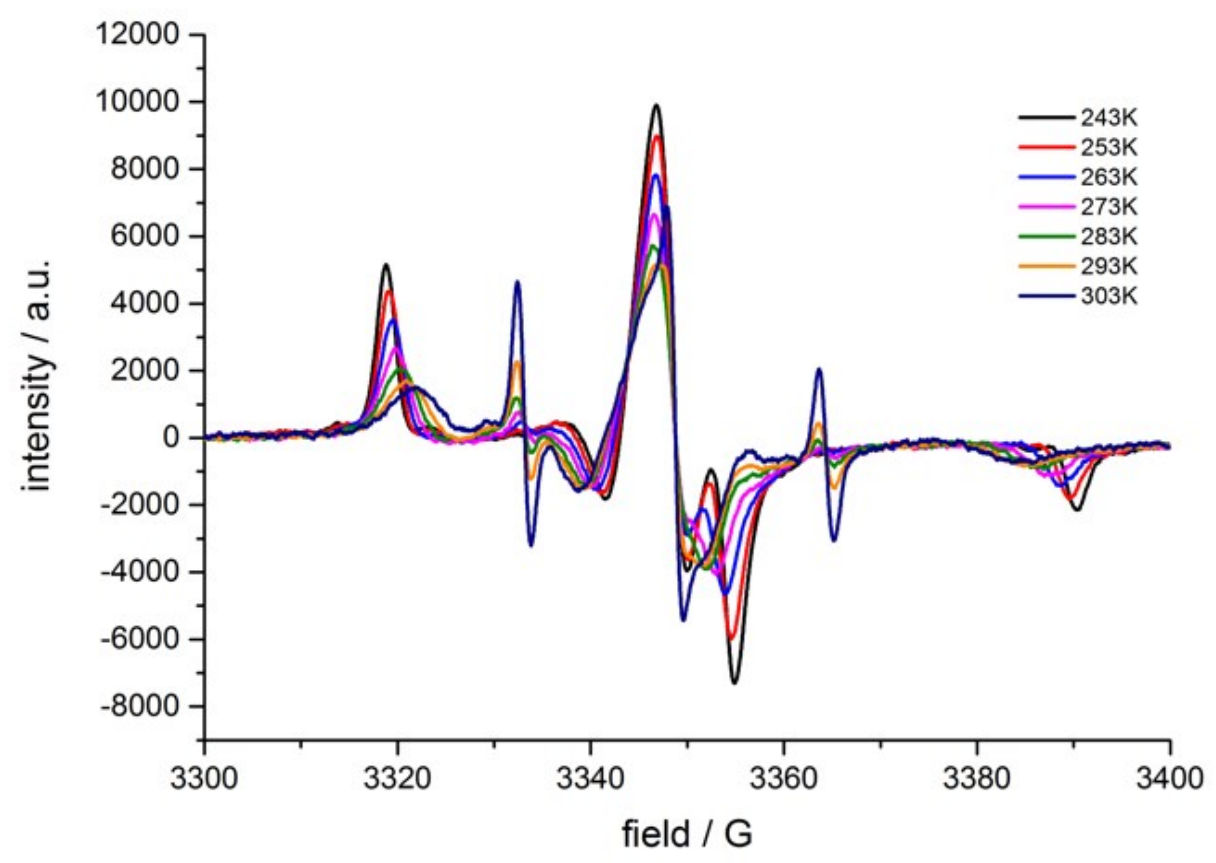

Figure S2. EPR spectra of the 14-mer RNA duplex ${ }^{5}$ CACGAUCCGAGGUC $\cdot 5^{\prime}$ GACCUCG_AUCGUG as a function of temperature. 


\section{Effect of flanking sequence on noncovalent spin labeling of RNA with Ǵ.}

Stacking interaction with the flanking nucleobases presumably contribute to binding of the spin label $\mathbf{G}$ to an abasic site in duplex RNA. A minor flanking sequence effect was observed when comparing purine-purine ( $\left.5^{\prime}-\mathrm{G}_{-} \mathrm{A}\right)$, purine-pyrimidine $\left(5^{\prime}-\mathrm{A} \_\mathrm{U}\right)$ and pyrimidine-pyrimidine $\left(5^{\prime}-C_{-} \mathrm{U}\right)$ base pairs immediately flanking the abasic site (Figure S2) at $-20{ }^{\circ} \mathrm{C}$. However, at $30{ }^{\circ} \mathrm{C}$ all flanking sequences showed full binding.

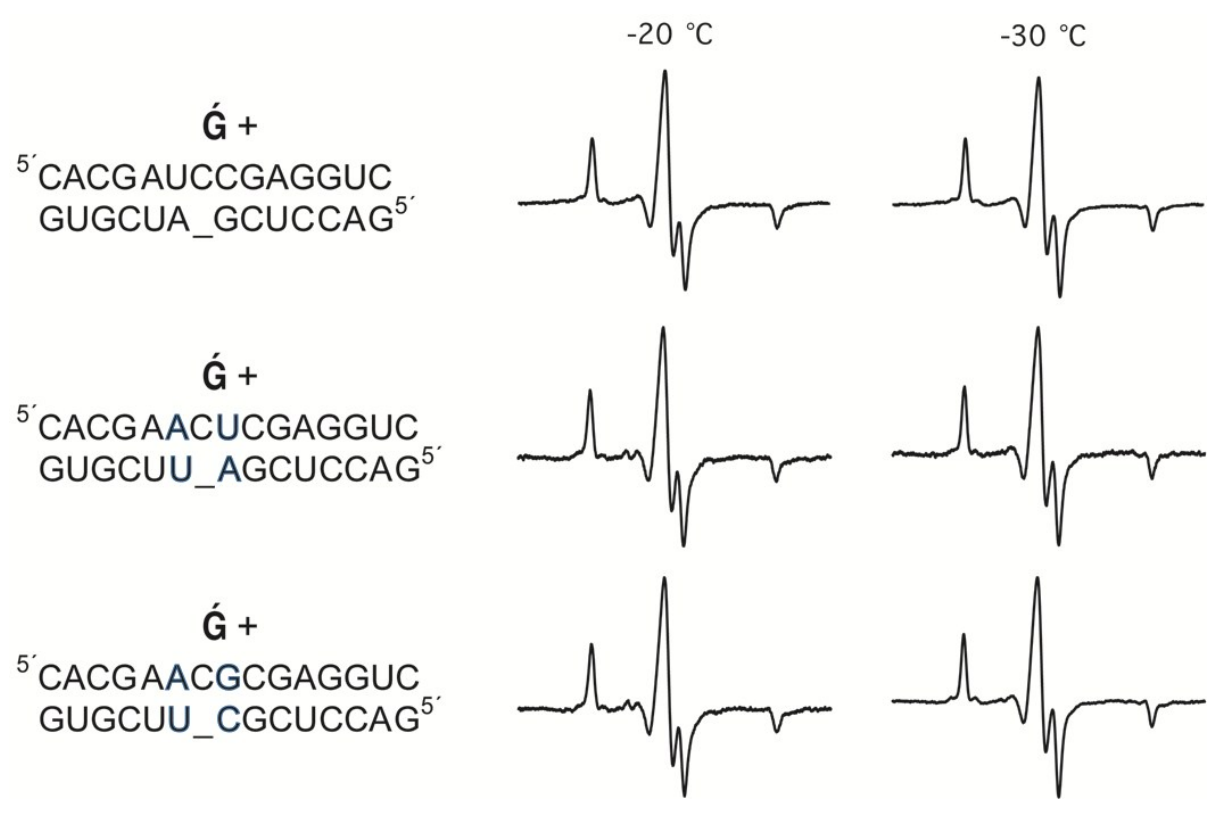

Figure S3. CW-EPR spectra of Ǵ $(200 \mu \mathrm{M})$ in the presence of a duplex RNA $(200 \mu \mathrm{M})$ containing an abasic site $\left(\_\right)$and varying flanking sequences. EPR spectra were recorded in in a phosphate buffer $\left(10 \mathrm{mM} \mathrm{NaHPO}_{4}, 100 \mathrm{mM} \mathrm{NaCl}\right.$, $0.1 \mathrm{mM} \mathrm{Na} \mathrm{F}_{2}$ EDTA, pH 7.0) containing 2\% DMSO and 30\% ethylene glycol.

\section{Determination of non-specific binding of Ǵ to an unmodified RNA duplex}

The degree of non-specific binding of $\mathbf{G}$ to RNA duplexes was determined by incubating $\mathbf{G}$ with an unmodified RNA duplex. A 14-mer RNA duplex was mixed with one equivalent of $\mathbf{G}$ and the EPR spectra were recorded at $-10{ }^{\circ} \mathrm{C},-20{ }^{\circ} \mathrm{C}$ and $-30{ }^{\circ} \mathrm{C}$ (Figure S4). Minor nonspecific binding $(<5 \%)$ was observed at $-30{ }^{\circ} \mathrm{C}$ but less than $1 \%$ at $-20{ }^{\circ} \mathrm{C}$ and none at $-10{ }^{\circ} \mathrm{C}$.

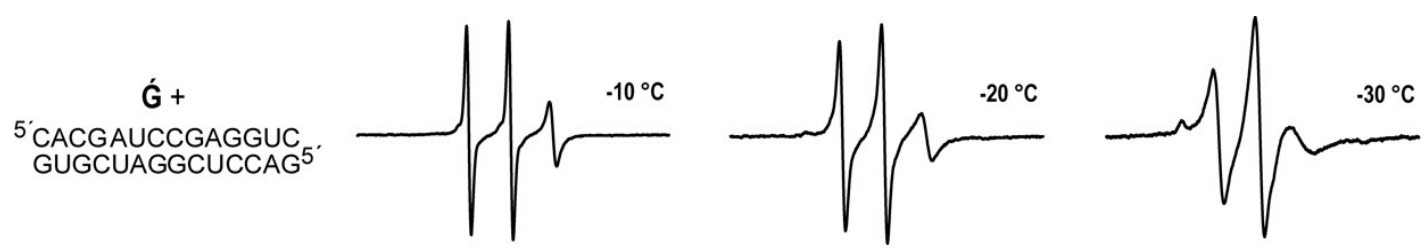

Figure S4. EPR spectra of $\mathbf{G}(200 \mu \mathrm{M})$ in the presence of an unmodified RNA $(200 \mu \mathrm{M})$ duplex. Measurements were recorded in a phosphate buffer $\left(10 \mathrm{mM} \mathrm{NaHPO}_{4}, 100 \mathrm{mM} \mathrm{NaCl}, 0.1 \mathrm{mM} \mathrm{Na} \mathrm{EDTA}_{2} \mathrm{pH} 7.0\right)$ containing $2 \%$ DMSO and $30 \%$ ethylene glycol. 
The specificity of binding was also investigated by a competition experiment, in which hypoxanthine was added in varying amounts to a sample containing $\mathbf{G}(200 \mu \mathrm{M})$ in the presence of an RNA duplex $(200 \mu \mathrm{M})$ containing an abasic site at $10^{\circ} \mathrm{C}$. Hypoxanthine has previously been used to rescue the catalytic activity of a hammerhead ribozyme containing an abasic site. ${ }^{7}$ Not unexpectedly, hypoxanthine (I) has a lower affinity to the abasic site than $\mathbf{G}$, but it is clear that it is competing with $\mathbf{G}$ for binding to the abasic site.

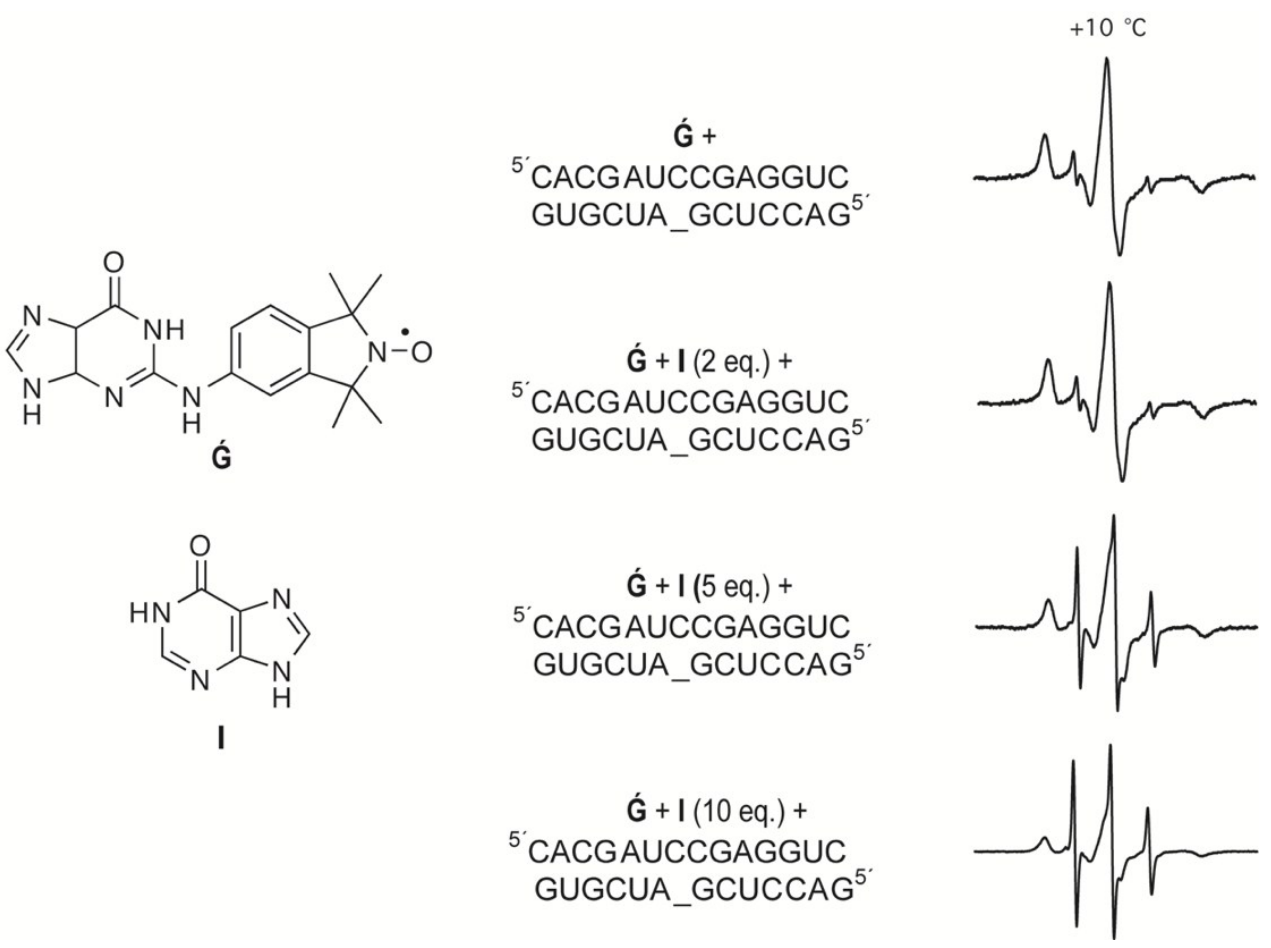

Figure S5. CW-EPR spectra of Ǵ (200 $\mu \mathrm{M})$ in the presence of a duplex RNA $(200 \mu \mathrm{M})$ containing an abasic site $\left(\_\right.$), along with increasing concentration of hypoxanthine (I) (0-10 equiv.). The EPR spectra were recorded in in a phosphate buffer ( $10 \mathrm{mM} \mathrm{NaHPO}_{4}, 100 \mathrm{mM} \mathrm{NaCl}, 0.1 \mathrm{mM} \mathrm{Na} 2$ EDTA, $\mathrm{pH} 7.0$ ) containing $2 \%$ DMSO and $30 \%$ ethylene glycol.

\section{Distance measurements on a noncovalently labeled RNA duplex by PELDOR}

A duplex RNA containing two abasic sites was constructed for PELDOR measurements (Figure S6). Before performing the PELDOR experiment, full binding of $\mathbf{G}$ to both the abasic sites was verified by CW-EPR spectroscopy. The noncovalently spin-labeled 22-mer RNA duplex were prepared by mixing appropriate self-complementary single-stranded RNA (4 nmol) with one equivalent of the spin label $\mathbf{G}$ ( $4 \mathrm{nmol})$. The water/ethanol solution was evaporated in vacuo and the residue dissolved in a phosphate buffer. After annealing the RNA oligomer, the solvent was removed in vacuo and the residue dissolved in sterile water $(10 \mu \mathrm{L})$ 
containing 2\% DMSO and 30\% ethylene glycol. The EPR spectra were recorded (Figure S6) and showed full binding of $\mathbf{G}$ at $-30^{\circ} \mathrm{C}$.

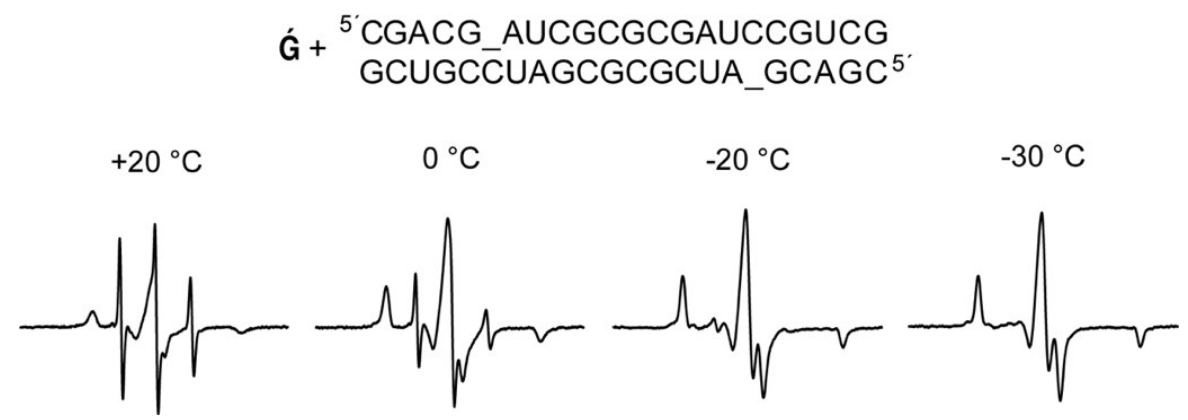

Figure S6. EPR spectra of $\mathbf{G}(400 \mu \mathrm{M})$ in the presence of a 22-mer RNA duplex ( $200 \mu \mathrm{M})$ containing two abasic sites, denoted as "_." EPR spectra were recorded in a phosphate buffer $\left(10 \mathrm{mM} \mathrm{NaHPO}_{4}, 100 \mathrm{mM} \mathrm{NaCl}, 0.1 \mathrm{mM}\right.$ $\mathrm{Na}_{2}$ EDTA, pH 7.0) containing 30\% ethylene glycol and and $2 \%$ DMSO.

The spin-labeled 22-mer RNA duplex was used for PELDOR measurements, using 40-90 MHz frequency offsets between the pump and probe pulses, in steps of $10 \mathrm{MHz}$. The resulting time traces with the indicated background correction (red lines) are shown in Figure S7.

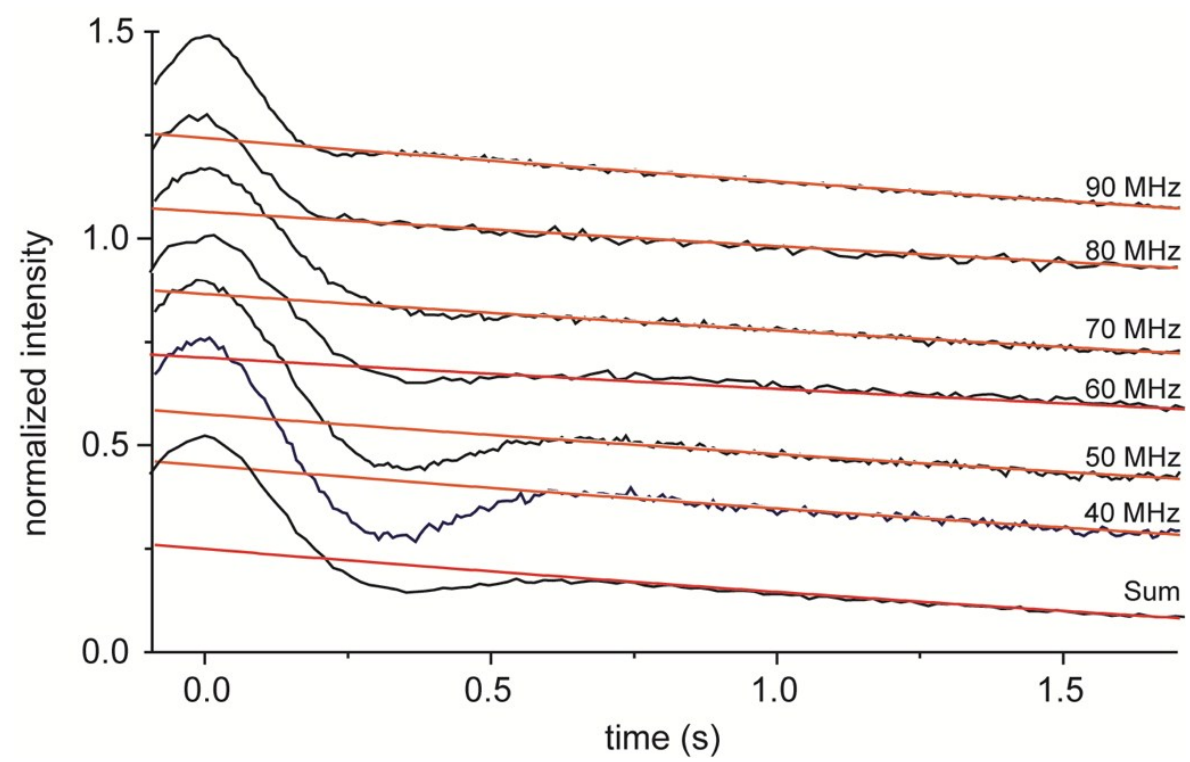

Figure S7. Original X-band PELDOR data for different offsets between the pump and probe pulses (black) along with the applied exponential background functions (red). The lowest trace shows the sum of all the frequency offsets.

\section{Molecular modeling of $G$ in the 22-mer RNA duplex containing two abasic sites.}

Molecular modeling was carried out on the RNA duplex in SPARTAN 10 (Wavefunction) using standard parameters. The abasic sites were generated by deleting the corresponding guanosine $(\mathrm{G})$ base. The spin label $\mathbf{G}$ was docked manually at the abasic sites so that it forms hydrogen bonds with the $\mathrm{C}$ on the opposite strand. The modeled structures were exported as 
PDB files and visualized in PyMOL (Delano Scientific LCC) (Figure S8). Rotation of the bond between the isoindoline nitroxide and N2 of guanine in $\mathbf{G}$, yielded different conformations. Figure S8 shows three structures resulting from two orientations of each label parallel to minor groove of the RNA. The distances between the spin labels in these three structures were measured to be $26.4 \AA, 28.7 \AA$ and $31.1 \AA$, yielding an average distance of $28.7 \AA$.
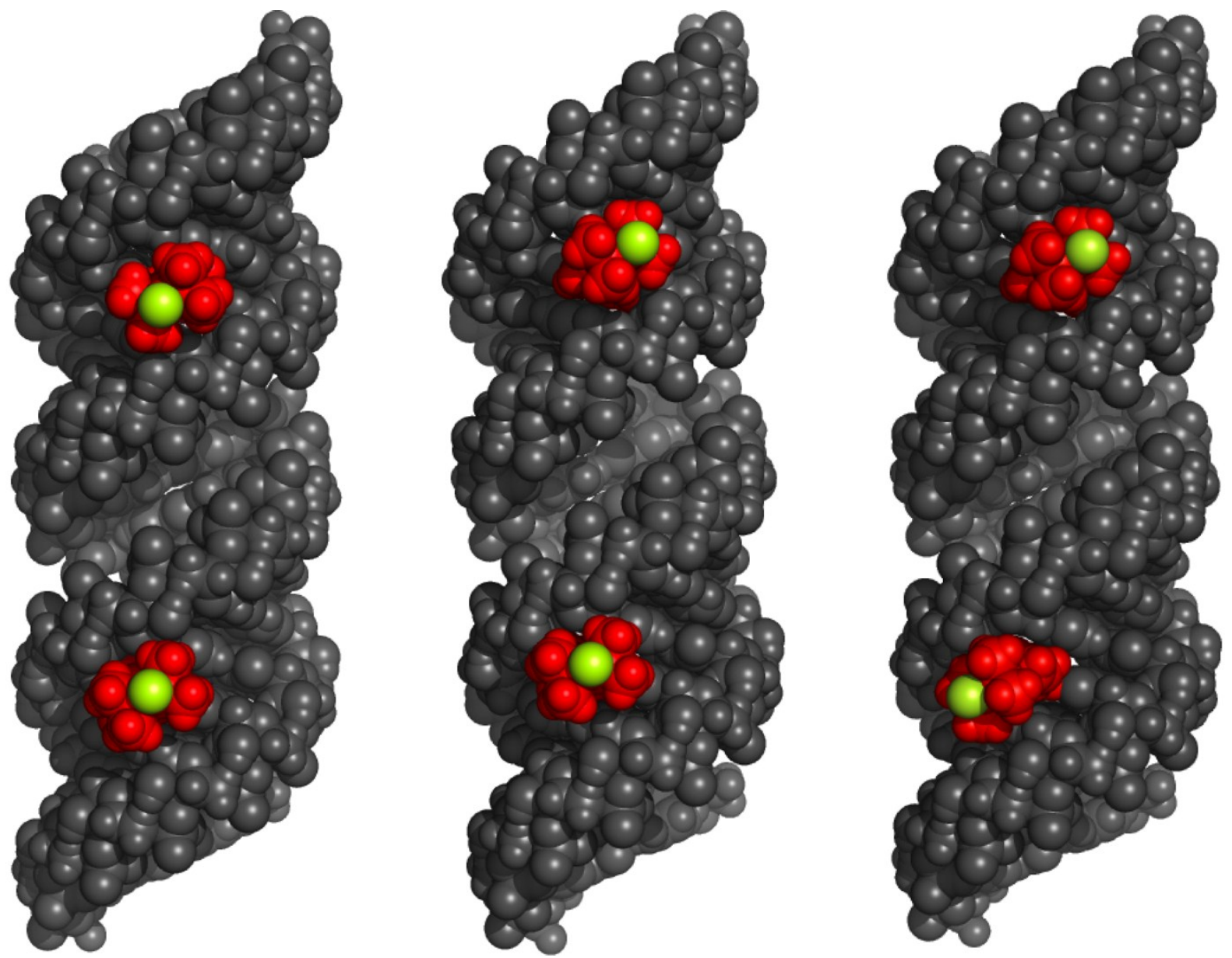

Figure S8. Molecular models of the noncovalently spin-labeled 22-mer RNA duplex in a space-filling representation showing relative position of the two Ǵs (red). The oxygen atoms of the nitroxide functional groups are shown in green.

\section{References}

(1) Lee, T. D.; Keana, J. F. Journal of Organic Chemistry 1975, 40 (21), 3145-3147.

(2) Li, Y.; Lei, X.; Li, X.; Lawler, R. G.; Murata, Y.; Komatsu, K.; Turro, N. J. Chem.Commun. 2011, 47 (46), 12527-12529.

(3) Beaman, A. G.; Gerster, J. F.; Robins, R. K. J.Org.Chem. 1962, 27 (3), 986-990.

(4) Reid, D.; Bottle, S. Chemical Communications 1998, (17), 1907-1908.

(5) Pannier, M.; Veit, S.; Godt, A.; Jeschke, G.; Spiess, H. W. Journal of Magnetic Resonance 2011, $213(2), 316-325$.

(6) Jeschke, G.; Chechik, V.; Ionita, P.; Godt, A.; Zimmermann, H.; Banham, J.; Timmel, C.; Hilger, D.; Jung, H. Applied Magnetic Resonance 2006, 30 (3-4), 473-498. 
(7) Peracchi, A.; Beigelman, L.; Usman, N.; Herschlag, D. Proc. Natl. Acad. Sci.U.S.A. 1996, 93 (21), 11522-11527. 
Paper II 


\title{
Purine-derived nitroxides for noncovalent spin-labeling of abasic sites in duplex nucleic acids
}

\author{
Nilesh R. Kamble and Snorri Th. Sigurdsson ${ }^{[a]}$
}

\begin{abstract}
A series of purine-based spin labels was prepared for noncovalent spin-labeling of abasic sites of duplex nucleic acids through hydrogen bonding to an orphan base on the opposing strand and pi-stacking interactions with the flanking bases. Both 1,1,3,3-tetramethylisoindolin-2-yloxyl and 2,2,6,6tetramethylpiperidine-1-oxyl (TEMPO) were conjugated to either the $\mathrm{C} 2$ - or C6-position of the purines, yielding nitroxide derivatives of guanine, adenine or 2,6-diaminopurine. The isoindoline-derived spin labels showed extensive or full binding to abasic sites in RNA duplexes while the TEMPO-derived spin labels showed limited binding. An adenine-derived spin label (5) bound fully at low temperature to abasic sites in both DNA and RNA duplexes when paired with thymine and uracil, respectively, complementing the previously described guanine-derived spin label $\mathbf{G}$, which binds efficiently opposite cytosine. Ǵ was also shown to bind to abasic sites in DNA-RNA hybrids, either in the DNA- or the RNA-strand. Ǵ showed only a minor flanking-sequence effect upon binding to abasic sites in RNA. When the abasic site was placed close to the end of the RNA duplex, the affinity of the spin label G was reduced; full binding was observed at the fourth position from the duplex end. In summary, spin labels $\mathbf{5}$ and $\mathbf{G}$ showed full binding to abasic sites in both DNA and RNA duplexes and are promising spin labels for structural studies of nucleic acids by pulsed EPR methods.
\end{abstract}

\section{Introduction}

Electron paramagnetic resonance (EPR) spectroscopy is a biophysical technique used for investigation of structure and dynamics of biomolecules, such as nucleic acids ${ }^{[1]}$ and proteins. ${ }^{[1 a, 1 e, 2]}$ EPR studies require a small amount of sample (nmoles) and can be carried out under biologically relevant conditions. Continuous-wave (CW) EPR spectroscopy provides information about dynamics of specific sites through line-shape analysis of EPR spectra. ${ }^{[1 \mathrm{~d}, 3]} \mathrm{CW}-\mathrm{EPR}$ has also been used for distance measurements between two spin centers in the range of $5-20 \AA,{ }^{[4]}$ whereas pulsed EPR methods, such as pulsed electron-electron double resonance (PELDOR), also called double electron-electron resonance (DEER), and double quantum coherence (DQC), have been used for longrange distance measurements $(20-100 \AA) \cdot{ }^{[1 a, 5]}$ When used in conjunction with rigid spin labels, PELDOR can also provide

[a] N. R. Kamble, Prof. S. T. Sigurdsson

Department of Chemistry

Science Institute

University of Iceland, Dunhaga 3, 107 Reykjavik, Iceland

E-mail:snorrisi@hi.is valuable information about the conformational dynamics of nucleic acids. ${ }^{[6]}$

Most EPR studies of nucleic acids require attachment of paramagnetic groups at specific sites, referred to as sitedirected spin labeling (SDSL). ${ }^{[1 \mathrm{~b}, 1 \mathrm{~g}, 7]}$ Stable aminoxyl radicals, commonly called nitroxides, are usually attached to the desired sites in the nucleic acid with covalent bonds. ${ }^{[7]}$ For covalent spin-labeling, two main approaches have been used. The first method utilizes spin-labeled phosphoramidites as building blocks for automated chemical synthesis of the spin-labeled oligonucleotide either directly ${ }^{[8]}$ or by using iodo-modified nucleobases for one-column coupling with spin labels. ${ }^{[9]}$ However, the phosphoramidite approach usually requires a significant synthetic effort and the reagents used for oligonucleotide synthesis can partially reduce the nitroxide spin labels. ${ }^{[10]}$ Post-synthetic labeling is another approach for covalent labeling, wherein a spin-labeling reagent is incubated with oligonucleotides that contain a uniquely reactive site. ${ }^{[11]}$ Post-synthetic modification usually requires less synthetic effort than the phosphoramidite approach and can often be performed with commercially available reagents. However, post-synthetic labeling can result in side reactions and incomplete labeling.

Noncovalent spin-labeling of nucleic acids utilizes binding through van der Waals interactions, hydrogen bonding and pi-stacking interactions. Spin-labeled intercalators and groove binders can bind to nucleic acids noncovalently, but lack the sequence specificity that is required for most EPR studies. ${ }^{[12]}$ There are a few examples of small molecules that bind noncovalently to specific sites of nucleic acids. Guanineguanine mismatch-binding ligands carrying spin labels have been used to bind to predetermined sites of nucleic acids. ${ }^{[13]}$ Abasic sites in duplex nucleic acids have also been used as binding sites for spectroscopic labels. For example, fluorescent compounds that bind to abasic sites have been developed by Taramae and co-workers for detection of single nucleotide polymorphisms in DNAs. ${ }^{[14]}$ Lhomme et al. used adenineacridine conjugates for noncovalent spin-labeling of a DNA duplex containing an abasic site, where the adenine bound to an abasic site and the acridine carrying the nitroxide spin label intercalated into the DNA duplex. ${ }^{[15]}$

We have previously used abasic sites in nucleic acids for noncovalent and site-directed spin labeling using pyrimidinederived spin labels. ${ }^{[16]}$ The spin label ç (Figure 1), which is an analogue of cytosine $(C)$, was found to bind specifically to abasic sites in duplex DNA opposite guanine $(G) .{ }^{[16 a]}$ This label has been used for determination of distance as well as relative orientation between two spin labels in duplex DNA and in DNAprotein complexes. ${ }^{[17]}$ However, the binding of $\mathrm{c}$ was highly flanking-sequence dependent, showing full binding to only a few sequences. Moreover, ç showed only partial binding to an 
abasic site of an RNA duplex. ${ }^{[16 c]}$ A series of pyrimidine-derived nitroxides was subsequently prepared and screened for binding to both DNA and RNA duplexes. ${ }^{[16 c]}$ Only triazolelinked nitroxide 1 (Figure 1) showed complete binding to abasic sites in RNA, but it was not a useful spin label due to extensive non-specific binding. ${ }^{[16 c]}$

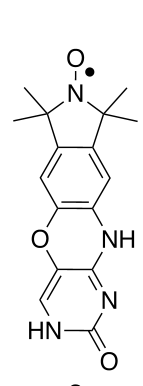

ç

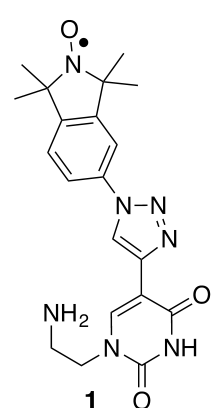

Figure 1. Structures of the spin label ç (left) and the triazole linked-nitroxide spin label $\mathbf{1}$ (middle). Proposed base-pairing of spin label Ǵ with $\mathbf{C}$ (right) at an abasic site in duplex nucleic acids.

Given the limitations of the pyrimidine-based spin labels for noncovalent binding, we turned our attention to purinederived nitroxides, as purines have a larger area for stacking interactions than pyrimidines. Recently, we reported the semiflexible Ǵ (G-spin, Figure 1), ${ }^{[18]}$ which is a conjugate of guanine and an isoindoline-derived nitroxide radical. The spin label Ǵ was found to bind specifically to abasic sites in DNA duplexes at low temperatures when paired with $C$ as an orphan base on the opposite strand. More importantly, Ǵ was found to bind with much higher affinity to RNA, providing for the first time, a spin label that bound effectively to specific sites in RNA through noncovalent interactions. ${ }^{[18]}$

In order to further explore the use of purine-derived nitroxides for noncovalent spin-labeling of abasic sites in duplex DNA and RNA, we have prepared five new spin labels (2-6, Figure 2). The isoindoline-derived spin labels showed good binding affinity and specificity to both DNA and RNA duplexes containing an abasic site but the TEMPO-derived spin labels bound poorly or not at all. Adenine (A)-derivative 5 bound fully to an abasic site in duplex RNA, providing the first nitroxide for noncovalent labeling of abasic sites opposite uridine $(U)$. Ǵ can be used as a spin label for abasic sites in DNA-RNA hybrids, although it binds with less affinity than to abasic sites in RNA. We also show that there is a minimal flanking-sequence dependence of $\mathbf{G}$ binding to abasic sites in RNA and that abasic sites need to be at least three base pairs away from the duplex end for complete binding.

\section{Results and Discussion}

The new purine-derived spin labels (Figure 2) contain nitroxides at either the C2- or the C6-position, affording either adenine-, guanine- or 2,6-diaminopurine-derived spin labels. Two different nitroxides, 2,2,6,6-tetramethylpiperidine-1-oxyl (TEMPO) and 1,1,3,3-tetramethylisoindolin-2-yloxyl, were conjugated to the purines. Assuming Watson-Crick pairing to either $\mathrm{U}$ or $\mathrm{C}$ on the opposite strand, guanine-derived compounds $\mathbf{6}$ and $\mathbf{G}$ were expected to direct the nitroxide into the minor groove, while the 6-amino modified adenine and 2,6diamino purine spin labels $\mathbf{2 - 5}$ would project the label into the major groove.<smiles>CC1(C)CC(Nc2ncnc3[nH]cnc23)CC(C)(C)N1O[N+]1(C)CC(Nc2nc(N)nc3[nH]cnc23)CC(C)(C)N1O</smiles>

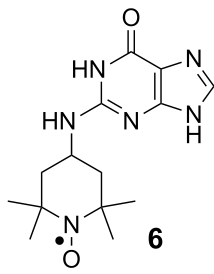

Figure 2. Structures of purine-derived spin labels 2-6.

\section{Syntheses of purine-derived spin labels}

The spin labels were synthesized from readily available halogen-derived purines through direct nucleophilic displacement reactions. Commercially available 2-amino-6chloropurine (7) was heated with either 4-amino TEMPO (8) or isoindoline nitroxide $\mathbf{9}^{[19]}$ to obtain 2,6-diamino purine derivatives 2 and 3, respectively (Scheme 1A and 1B). 6Chloropurine (10) was reacted with 8 or 9 under similar conditions to give the corresponding spin-labeled adenine derivatives 4 and $\mathbf{5}$ (Scheme 1C and 1D). For the synthesis of the guanine-derived TEMPO derivative $\mathbf{6}$, we first attempted a reaction between 8 and 2-bromohypoxanthine in DMF in the presence of triethylamine, but this resulted in a complex mixture of products (data not shown). Hence, the following sequence of reactions was used instead. 2-Amino-6-benzyloxy purine $^{[20]}(7)$ was reacted with sodium nitrite in the presence of tetrafluoroboric acid $^{[21]}$ to yield 2-fluoro-6-benzyloxypurine ${ }^{[20]}$ (11) (Scheme 1E). Compound 11 was subsequently reacted with 4-amino TEMPO (8) to give 12 in moderate yield, which upon debenzylation gave the target compound 6 in excellent yield. 
A

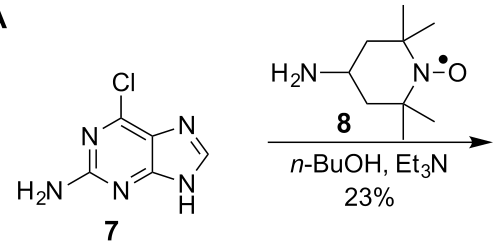

B

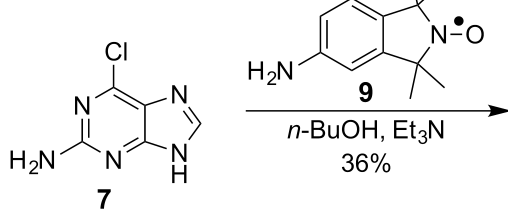

C

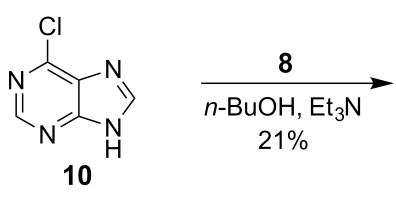

D

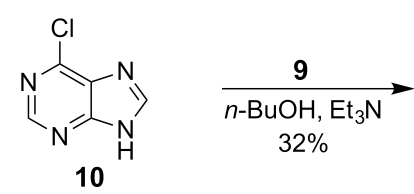

E<smiles>CCOc1ncc(N)nc1N</smiles><smiles>[Y20][C@]1(C)C[C@H](Nc2nc(OCc3ccccc3)c3nc[nH]c3n2)CC(C)(C)N1O</smiles>

$\mathrm{Bn}$

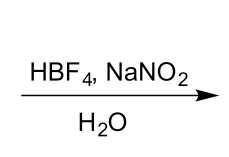<smiles>CC1(C)CC(Nc2nc(N)nc3[nH]cnc23)CC(C)(C)N1O</smiles><smiles></smiles><smiles>CC1(C)CC(Nc2ncnc3[nH]cnc23)CC(C)(C)N1O</smiles><smiles>CC1(C)c2ccc(Nc3ncnc4[nH]cnc34)cc2C(C)(C)N1[O-]</smiles><smiles>Fc1nc(OCc2ccccc2)c2nc[nH]c2n1</smiles>
$\underset{\mathrm{DMF}, \mathrm{NEt}_{3}}{\longrightarrow}$

11 $32 \%$<smiles>CC1(C)CC(Nc2nc3[nH]cnc3c(=O)[nH]2)CC(C)(C)N1O</smiles>

Scheme 1. Synthetic schemes for spin labels 2-6.

\section{Binding of the spin labels to abasic sites in duplex DNA}

The binding-affinity and -specificity of spin labels 2-6 to abasic sites in DNA duplexes were determined by EPR spectroscopy. Each spin label was incubated with a 14-mer duplex DNA containing $\mathrm{G}, \mathrm{T}, \mathrm{A}$ or $\mathrm{C}$ as the orphan base at $-30{ }^{\circ} \mathrm{C}$ (Figure 3). The EPR spectrum of each spin label (Figure 3, far left column) showed comparatively narrow lines, because of the

fast tumbling of the radical in solution. In the presence of the DNA duplexes containing an abasic site, the appearance of a slow moving component in the spectrum (arrows in the top left spectrum) indicated binding of the spin label to the DNA. All the spin labels showed some binding affinity towards at least one DNA duplex. Two spectra indicated nearly full binding to the abasic site (Figure 3, spectra in boxes), for previously reported spin label Ǵ opposite $C$ and adenine-derived spin label $\mathbf{5}$ opposite thymine (T). The TEMPO derivatives 2, $\mathbf{4}$ and 6 showed very poor binding, whereas the 2,6-diaminopurine derivative 3 showed moderate binding to the abasic sites of the DNA duplexes. To verify that the spin labels bind to the abasic site specifically, they were individually mixed with an unmodified 14-mer DNA duplex (Figure 3, far right column). Isoindoline-derived spin labels $\mathbf{G}, \mathbf{3}$ and $\mathbf{5}$ showed very minor non-specific binding $(<2 \%)$.

\section{Binding of the spin labels to abasic sites in duplex RNA}

Binding affinity of these spin labels to abasic sites in RNA duplexes was also investigated (Figure 4). Here, the TEMPOderived spin labels $\mathbf{4}$ and $\mathbf{6}$ also showed very limited binding, while the 2,6-diamino derivative 2 showed extensive binding opposite $\mathrm{C}$. The isoindoline-derived spin labels $\mathbf{G}, \mathbf{3}$ and $\mathbf{5}$ had higher affinity to the abasic sites in RNA duplexes than in DNA duplexes, showing full or nearly full binding to at least one sequence (Figure 4, black boxes). Ǵ bound to an abasic site opposite $C, 2,6$-diamino purine 3 opposite $U$ while adenine derivative 5 bound opposite both pyrimidines, although it bound better to $U$. It is noteworthy that all these spin labels show the best binding to abasic sites that contain an orphan base, which that can form Watson-Crick base pairs with the spin label.

In order to obtain information about the relative affinities of the isoindoline-derived spin labels $\mathbf{G}, \mathbf{3}$ and $\mathbf{5}$, the temperature dependence of their binding was investigated (Figure 5). Spin label Ǵ was by far the best binder, as extensive binding was observed even at $20{ }^{\circ} \mathrm{C}\left(>95 \%, K_{d}=\right.$ $\left.6.15 \times 10^{-6} \mathrm{M}\right)^{[16 a]}$ at which temperature spin labels $\mathbf{3}$ and $\mathbf{5}$ showed nearly no binding.

\section{Binding of the spin labels to abasic sites in DNA-RNA hybrids}

DNA-RNA hybrids are heterogeneous nucleic acids and key intermediates in many important biological processes. ${ }^{[22]}$ These hybrids are recognized by RNase $\mathrm{H}$ and have been used for biomedical technologies such as antisense therapies. ${ }^{[22 c, 23]}$ Structures of several hybrids have been characterized using nuclear magnetic resonance (NMR) spectroscopy ${ }^{[24]}$ and X-ray crystallography ${ }^{[25]}$ and shown to be in an A-form duplex. Spin labeling of DNA-RNA hybrid duplexes have, to our knowledge, not been explored before. 


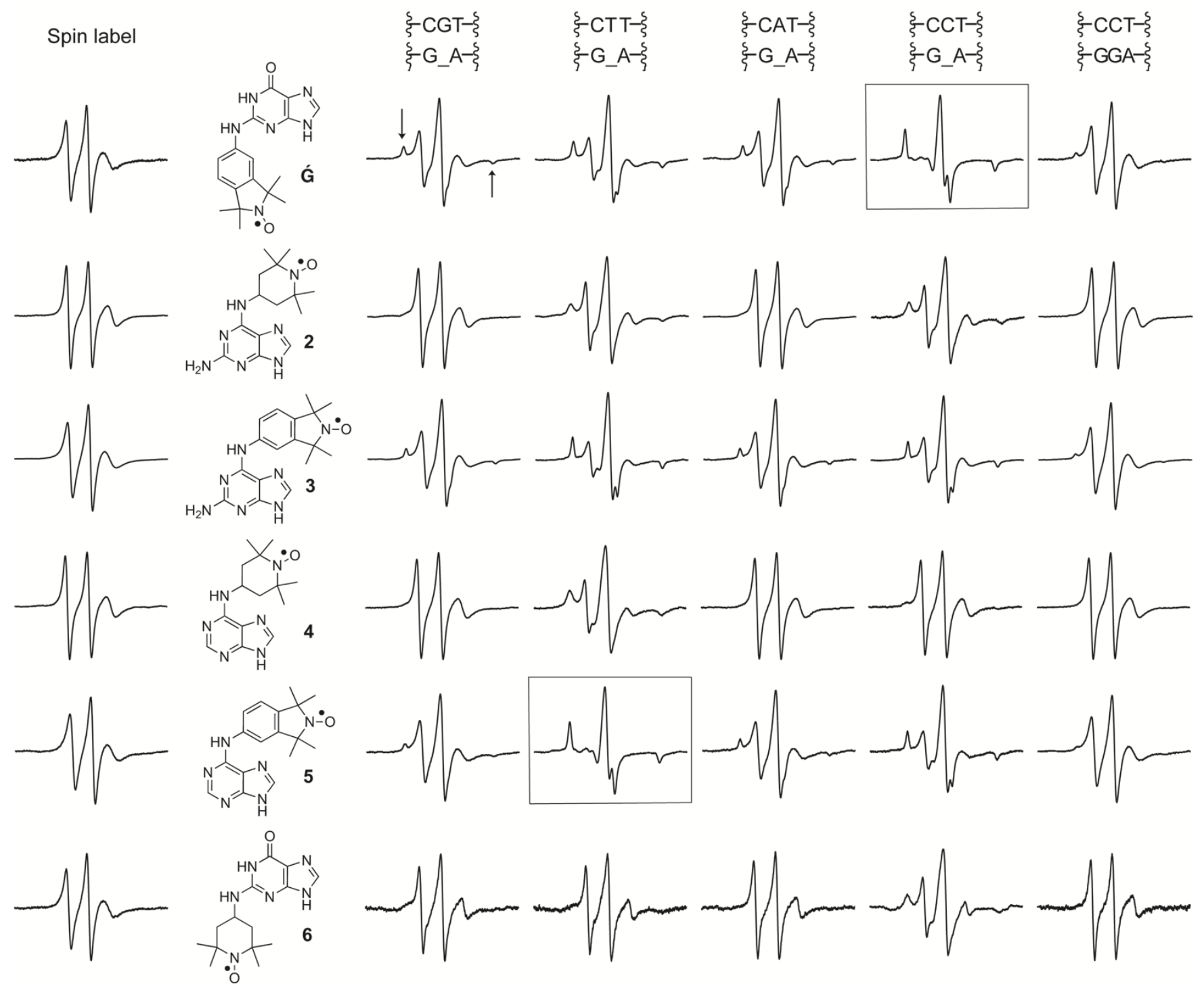

Figure 3. EPR spectra of the spin labels are shown on the far left and EPR spectra of the labels in the presence of an unmodified DNA on the far right. The central four columns of EPR spectra show the spin-label in presence of DNA duplexes containing an abasic site (denoted by "_") opposite the orphan bases G, T, A and C. Only a part of construct is shown on top; the complete DNA sequence is 5'-d(GACCTCG_ATCGTG)-3'·5'-d(CACGATXCGAGGTC)-3', where X represents the orphan base (G, T, A or $\mathrm{C}$ ). The arrows by the spectra in the top left corner identify a slow moving component in the EPR spectra, which indicates binding of a spin label to the nucleic acid. EPR spectra inside the black boxes showed almost fully bound $\mathbf{G}$ and $\mathbf{5}$ to the abasic site of a DNA duplex opposite $\mathrm{C}$ and $\mathrm{T}$, respectively. EPR spectra of the spin labels $(200 \mu \mathrm{M})$ in the presence of DNA duplexes $(400 \mu \mathrm{M})$ were recorded in a phosphate buffer $(10 \mathrm{mM} \mathrm{NaHPO}, 100 \mathrm{mM} \mathrm{NaCl}, 0.1 \mathrm{mM}$ $\mathrm{Na}_{2}$ EDTA, $\mathrm{pH} 7.0$ ) containing $30 \%$ ethylene glycol and $2 \%$ DMSO at $-30{ }^{\circ} \mathrm{C}$. The spectra were phase-corrected and aligned with respect to the height of the central peak.

Given the extensive binding of the spin label Ǵ to abasic sites in RNA, we selected it to probe its binding to abasic sites in DNA-RNA duplexes.

To evaluate the binding affinity of $\mathbf{G}$ to the abasic site of DNA-RNA duplexes, two 14-mer duplexes were prepared. The first duplex contained an abasic site in the DNA strand (DNARNA I) and in the second duplex, the abasic site was placed in the RNA strand (DNA-RNA II). Figure 6 shows that $\mathbf{G}$ bound fully to both hybrid duplexes at $-30^{\circ} \mathrm{C}$, extensive binding was even observed at $0{ }^{\circ} \mathrm{C}$. However, increasing the temperature to $20{ }^{\circ} \mathrm{C}$ resulted in almost complete loss of binding. We determined the binding affinities of $\mathbf{G}$ to all the duplexes (DNADNA, RNA-RNA and DNA-RNA), where the abasic site was opposite $C$ (see supporting information Figure S1). Ǵ had the highest affinity to the RNA duplex $\left(K_{d}=1.46 \times 10^{-7} \mathrm{M}\right)$, the second highest to the DNA-RNA $\left(K_{d}=9.75 \times 10^{-7} \mathrm{M}\right)$ and the lowest affinity to the DNA duplex $\left(K_{d}=60.17 \times 10^{-7} \mathrm{M}\right)$. Thus, the binding affinity of $\mathbf{G}$ decreased six-fold when bound to DNA-RNA hybrids and a 41 -fold when it was bound to the DNA duplex at $0{ }^{\circ} \mathrm{C}$, compared to the RNA duplex. 


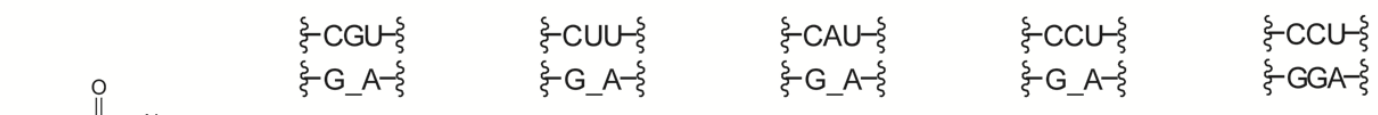
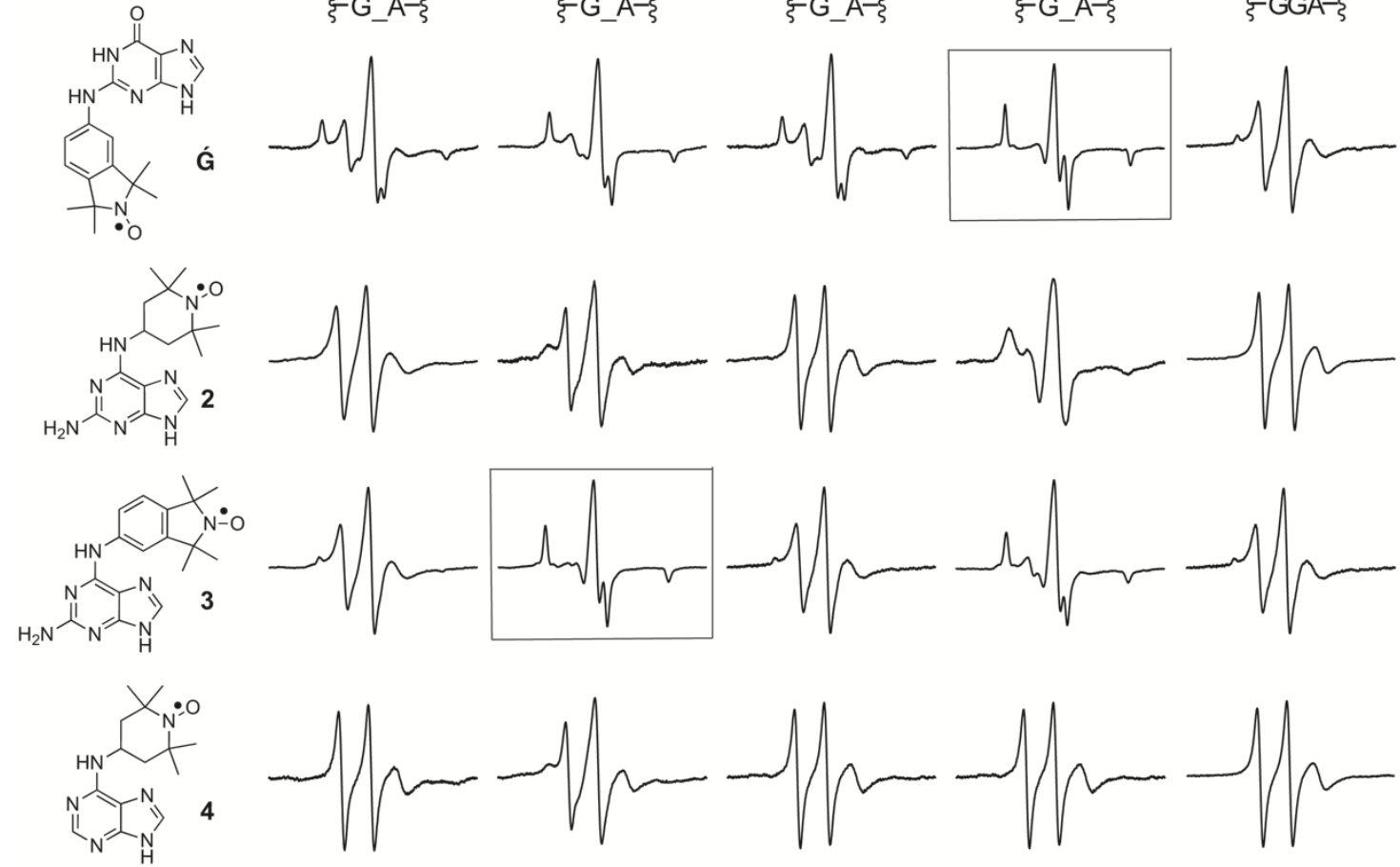<smiles>CCCCC(C)CCC</smiles><smiles>CCCCCCCCC</smiles><smiles>CCCCCCCC</smiles><smiles>CC1(C)c2ccc(Nc3ncnc4[nH]cnc34)cc2C(C)(C)[N+]1=O</smiles><smiles>CCCCCCCCCCCCCCCCCCC</smiles><smiles>CCCCCCC</smiles>

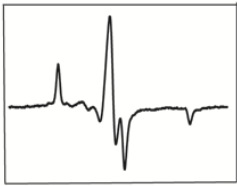<smiles>CCCCCCC</smiles><smiles>CC1(C)CC(Nc2nc3[nH]cnc3c(=O)[nH]2)CC(C)(C)N1O</smiles><smiles>CCCC1C(CC)CCC1CC</smiles><smiles>CCCC1CCCC(CC)C1CCC</smiles><smiles>CCCC1CCCC(CC)C1C</smiles><smiles>CCCCCCCCCCCCCCCCC</smiles><smiles>CCCC1CCCCC1CC</smiles>

Figure 4. Binding of spin labels to abasic sites in RNA duplexes. EPR spectra of spin labels in the presence of an unmodified RNA are shown on the far right. The central four columns of the EPR spectra show the spin labels in the presence of RNAs containing an abasic site (denoted by “_") opposite the orphan bases G, U, A and C. Only a part of construct is shown on top; the complete RNA sequence is 5'-GACCUCG_AUCGUG-3'.5'-CACGAUXCGAGGUC-3', where X represents the orphan base $(G, U, A$ or $C)$. EPR spectra inside the black boxes indicate full or nearly full binding. EPR spectra of the spin labels $(200 \mu M)$ in the presence of RNA duplexes $(400 \mu \mathrm{M})$ were recorded in a phosphate buffer (10 $\mathrm{mM} \mathrm{NaHPO}_{4}, 100 \mathrm{mM} \mathrm{NaCl}, 0.1 \mathrm{mM} \mathrm{Na}_{2} \mathrm{EDTA}$, pH 7.0) containing $30 \%$ ethylene glycol and $2 \%$ DMSO at $-30{ }^{\circ} \mathrm{C}$.

\section{Effect of structural changes in RNA duplexes on binding of Ǵ}

Three main factors contribute to spin-label binding to an abasic site. First, hydrogen bonding of the spin-label base to the orphan base on the opposing strand, as described above. Second, the identity of the bases flanking the abasic site will affect the stacking interaction with the spin label. Third, placement of the abasic site close to the end of the duplex might compromise the structural integrity of the abasic binding site, since terminal base pairs are more dynamic than the central base pairs. ${ }^{[26]}$ We decided to investigate the latter two factors in RNA using the spin label with the highest affinity (G).

To probe the effect of the location of the abasic site relative to the duplex end on spin-label binding, four different 14-mer RNA duplexes (III-VI, Figure 7) were prepared, such that the position of the abasic site was moved one base pair at a time from the 5'-end towards the centre of the duplex. Quite remarkably, Ǵ showed extensive binding when a single Coverhang was placed at the end of the RNA duplex (III), similar 
<smiles>CC(C)(C)c1ccc(Nc2nc3[nH]cnc3c(=O)[nH]2)cc1C(C)(C)C</smiles><smiles>CCO[GeH2]C(C)(C)C</smiles>

₹्ञCUU $\}$ हैG_A-<smiles>C=C(C)C(C)(C)C</smiles><smiles>CCC(C)C(C)C(C)(C)C</smiles><smiles>CCCCC(C)N(C)CC</smiles><smiles>CCCCNCCCC</smiles><smiles>CCCCCCCC(C)C(C)C</smiles><smiles>CCCCCCCCCC(C)CC</smiles>

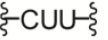
हैG_A-
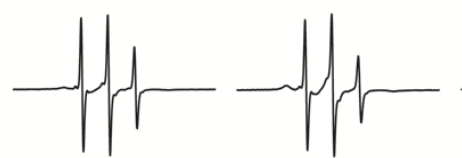

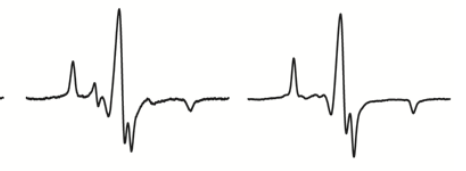

Figure 5. EPR spectra of the spin labels in the presence of an RNA duplex containing an abasic site at different temperatures. Only a part of construct is shown; the complete RNA sequence is 5'-GACCUCG_AUCGUG-3'-5'-CACGAUXCGAGGUC-3'; the abasic site (denoted by “_") and X represents orphan base C or U. EPR spectra of the spin labels $(200 \mu \mathrm{M})$ in the presence of RNA duplexes $(400 \mu \mathrm{M})$ were recorded in a phosphate buffer $(10 \mathrm{mM} \mathrm{NaHPO}, 100 \mathrm{mM} \mathrm{NaCl}, 0.1 \mathrm{mM}$ $\mathrm{Na}_{2}$ EDTA, pH 7.0) containing $30 \%$ ethylene glycol and $2 \%$ DMSO.

\section{Ǵ +} $\begin{array}{cc}\text { 5'CACGAUCCGAGGUC }^{\prime} & { }^{\prime} \text { d(CACGAUCCGAGGUC) } \\ \text { d(GTGCTA_GCTCCAG) })^{\prime} & \text { GUGCUA_GCUCCAG 5 } \\ \text { | } & \text { | I }\end{array}$
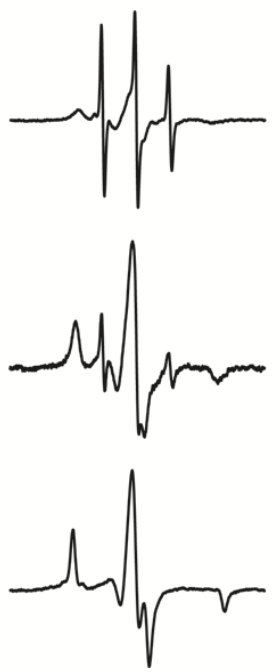

Ǵ +
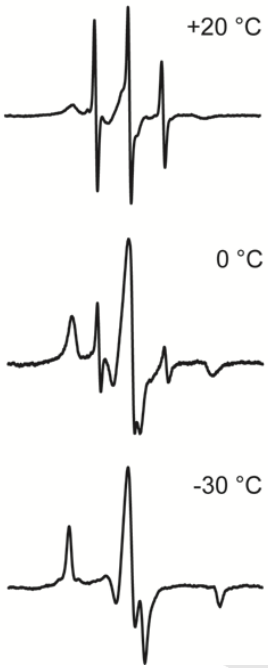

To investigate the binding efficiency of $\mathbf{G}$ as a function of the identity of the base pairs immediately flanking the abasic site, a series of sixteen 14-mer RNA duplexes, with all possible combinations of the flanking bases, were prepared and incubated with G. Visual inspection of the EPR spectra (see supporting information, Figure S2) revealed relatively minor variations in the extent of binding between the flanking sequences. The binding was quantified by determining the dissociation constant $\left(K_{\mathrm{d}}\right)$ at $20{ }^{\circ} \mathrm{C}$ for all the flanking sequences, which showed a variation of $K_{d}$ within a factor of two (see supporting information, Figure S3). For comparison, up to 15 -fold difference in the $K_{d}$ was observed between flanking sequences for binding of the spin label ç to abasic sites in DNA duplexes. ${ }^{[16 \mathrm{~b}]}$ For a given base at the 5 '-side of the abasic site, the highest affinity for $\mathbf{G}$ was observed for a $U$ at the 3 '-side.

Figure 6. Binding of $\mathbf{G}$ to an abasic site of DNA-RNA hybrid duplexes. The DNA-RNA I contained an abasic site in the DNA strand (left column), whereas the DNA-RNA II contained an abasic site in the RNA strand (right column) and the abasic sites are denoted by " ". EPR spectra of $\mathbf{G}(200 \mu \mathrm{M})$ in the presence of DNA-RNA hybrid $(400 \mu \mathrm{M})$ were recorded in a phosphate buffer (10 mM NaHPO $, 100 \mathrm{mM} \mathrm{NaCl}, 0.1 \mathrm{mM} \mathrm{Na} \mathrm{NaDTA}_{2} \mathrm{pH}$ 7.0) containing $30 \%$ ethylene glycol and $2 \%$ DMSO.

to the degree of binding to an abasic site placed one base pair away from the end of the duplex (IV). When the abasic site was placed at the third position from the duplex terminus $(\mathbf{V})$, the spin label bound fully at $-30^{\circ} \mathrm{C}$. However, the data recorded at $-20{ }^{\circ} \mathrm{C}$ shows that the abasic site need to be at least at the fourth position from the duplex end $(\mathbf{V I})$ to achieve full binding. 

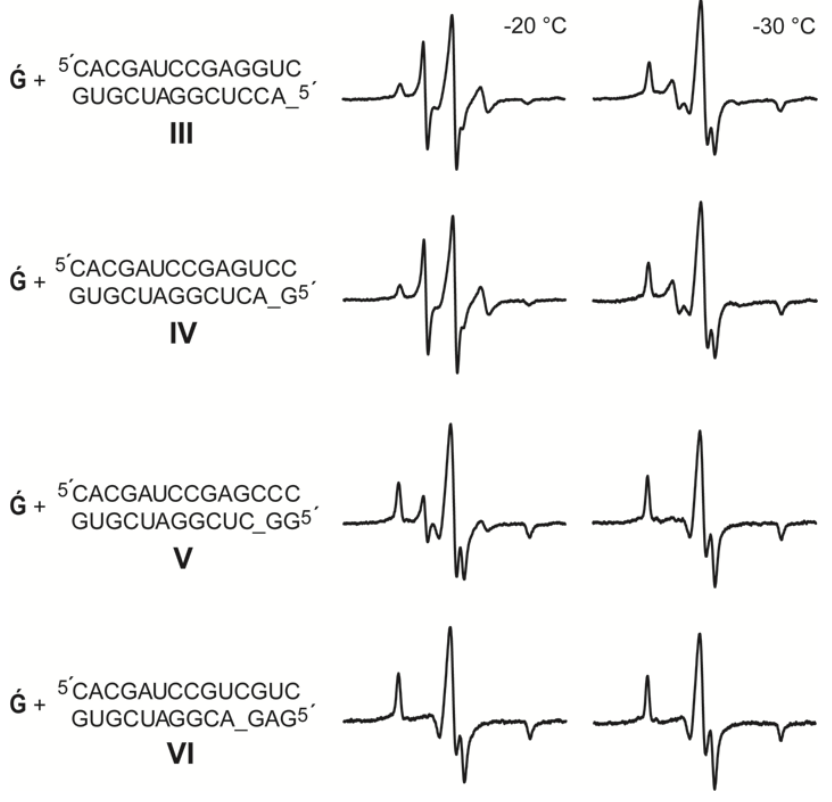

Figure 6. Binding of $\mathbf{G}(200 \mu \mathrm{M})$ to RNA $(400 \mu \mathrm{M})$ duplexes (III-VI) containing abasic sites (denoted by “"”), where the location of the abasic site is moving from the 5'-end to the centre of duplex. All EPR spectra were recorded in a phosphate buffer $(10 \mathrm{mM} \mathrm{NaHPO}, 100 \mathrm{mM} \mathrm{NaCl}, 0.1 \mathrm{mM}$ $\mathrm{Na}_{2}$ EDTA, pH 7.0) containing $30 \%$ ethylene glycol and $2 \%$ DMSO.

\section{Conclusion}

In conclusion, we have demonstrated that readily synthesized purine-derived nitroxide spin labels can be used for noncovalent spin-labeling of abasic sites in nucleic acid duplexes, in particular RNA-RNA duplexes. Specifically, isoindoline-derived spin labels $\mathbf{3}, \mathbf{5}$ and $\mathbf{G}$ are superior for noncovalent spin-labeling when compared to the TEMPOderived spin labels 2, 4 and $\mathbf{6}$. The adenine derivative $\mathbf{5}$ and the guanine-nitroxide conjugate $\mathbf{G}$ bound efficiently to an abasic site of DNA duplexes and showed full binding to RNA duplexes. For all spin labels, the highest extent of binding was observed when the orphan base offered the possibility of Watson-Crick pairing, i.e. when the adenine derivatives bound to $T$ (DNA) or $U$ (RNA) or the guanine derivatives to $C$. This indicates that hydrogen bonding is a significant contributor to spin-label binding. The adenine spin label 5 showed full binding to an abasic site of an RNA duplex opposite $U$ and complements $\mathbf{G}$ as a spin label, which pairs with $\mathrm{C}$. It was also demonstrated that $\mathbf{G}$ binds efficiently to abasic sites of DNARNA hybrids. Only a minor flanking-sequence effect was observed upon binding of $\mathbf{G}$ to an abasic site in RNA-RNA duplexes. Thus, spin labels $\mathbf{G}$ and $\mathbf{5}$ are promising spin labels for structural studies of RNA and its complexes with macromolecules.

\section{Experimental section}

\section{General materials and methods}

All reagents were purchased from Sigma-Aldrich and were used without further purification. Dichloromethane and acetonitrile were dried over calcium hydride and freshly distilled before use. Thin layer chromatography (TLC) was performed using glass plates pre-coated with silica gel $(0.25$ $\mathrm{mm}, \mathrm{F}-25$, Silicycle) and compounds were visualized by UV light. Column chromatography was performed using 230-400 mesh silica gel (Silicycle). ${ }^{1} \mathrm{H}$ NMR spectra were recorded with a Bruker Avance $400 \mathrm{MHz}$ spectrometer. Chemical shifts were reported in parts per million (ppm) relative to the partially deuterated NMR solvent $d_{6}$-DMSO (2.50 ppm). Nitroxide radicals show significant broadening in NMR spectra and loss of NMR signals due to their paramagnetic nature ${ }^{[27]}$ and, therefore, those spectra are not reported. The EPR spectra of the radicals are shown in the supporting information. Mass spectrometric analyses were performed on an HRMS-ESI (Bruker, MicroTOF-Q) in a positive ion mode. All EPR data were recorded in a phosphate buffer $\left(10 \mathrm{mM} \mathrm{NaHPO}_{4}, 100 \mathrm{mM}\right.$ $\mathrm{NaCl}, 0.1 \mathrm{mM} \mathrm{Na}{ }_{2} \mathrm{EDTA} ; \mathrm{pH} 7$ ) containing $30 \%$ ethylene glycol and $2 \%$ DMSO.

\section{General procedure for the syntheses of spin labels 2-5}

6-Chloropurine $\mathbf{7}$ or $\mathbf{1 0}(0.29 \mathrm{mmol})$ and nitroxide radical $\mathbf{8}$ or $\mathbf{9}$ $(0.29 \mathrm{mmol})$ were added to a solution of $n-\mathrm{BuOH}(4 \mathrm{~mL})$ and $\mathrm{Et}_{3} \mathrm{~N}(0.88 \mathrm{mmol})$. The reaction mixture was heated at $120^{\circ} \mathrm{C}$ for $16 \mathrm{~h}$, cooled to room temperature and the solvent was evaporated in vacuo. The crude product was purified by flash column chromatography (silica gel) using a gradient elution $\left(\mathrm{CH}_{2} \mathrm{Cl}_{2} / 30 \% \mathrm{NH}_{3}\right.$ in $\mathrm{MeOH} ; 100: 0$ to $\left.90: 10\right)$ to give compounds 2-5 as a pale-yellow solid.

Compound 2: $(20 \mathrm{mg}, 22 \%) ; R_{\mathrm{f}}=0.22\left(\mathrm{CH}_{2} \mathrm{Cl}_{2} / \mathrm{MeOH} 9: 1\right)$; HRMS-ESI: $m / z$ calcd for $\mathrm{C}_{14} \mathrm{H}_{22} \mathrm{~N}_{7} \mathrm{O}[\mathrm{M}+\mathrm{H}]^{+} 305.1959$, found 305.1950 .

Compound 3: (24 mg, 25\%) $R_{\mathrm{f}}=0.25\left(\mathrm{CH}_{2} \mathrm{Cl}_{2} / \mathrm{MeOH}\right.$ 9:1); HRMS-ESI: $m / z$ calcd for $\mathrm{C}_{17} \mathrm{H}_{20} \mathrm{~N}_{7} \mathrm{O}[\mathrm{M}+\mathrm{H}]^{+} 339.1808$, found 339.1783.

Compound 4: (15 mg, 16\%) $R_{\mathrm{f}}=0.28\left(\mathrm{CH}_{2} \mathrm{Cl}_{2} / \mathrm{MeOH} 9: 1\right)$; HRMS-ESI: $m / z$ calcd for $\mathrm{C}_{17} \mathrm{H}_{20} \mathrm{~N}_{7} \mathrm{O}[\mathrm{M}+\mathrm{H}]^{+} 290.1849$, found 290.1850 .

Compound 5: $(30 \mathrm{mg}, 29 \%) R_{\mathrm{f}}=0.28\left(\mathrm{CH}_{2} \mathrm{Cl}_{2} / \mathrm{MeOH} 9: 1\right)$; HRESI-MS: $\mathrm{m} / \mathrm{z}$ calcd for $\mathrm{C}_{17} \mathrm{H}_{19} \mathrm{~N}_{6} \mathrm{O}[\mathrm{M}+\mathrm{H}]^{+} 324.1693$, found 324.1674 .

Compound 11: Compound 7 (100 mg, $0.41 \mathrm{mmol}$ ) was added to $50 \%$ aqueous tetrafluoroboric acid $(10 \mathrm{~mL})$ and the solution was stirred at $-20{ }^{\circ} \mathrm{C}$ for $15 \mathrm{~min}$, followed by addition of aqueous sodium nitrite $(2 \mathrm{~mL}, 1.5 \mathrm{M})$. The reaction mixture was stirred for $1 \mathrm{~h}$ at $-10^{\circ} \mathrm{C}$, followed by neutralization with a satd. solution of sodium carbonate at $10{ }^{\circ} \mathrm{C}$. The precipitate was filtered off and washed with cold water $(10 \mathrm{~mL})$ and dried in vacuo to yield compound $\mathbf{1 1}$ as a pale-yellow solid $(50 \mathrm{mg}$, $50 \%$ yield). $R_{\mathrm{f}}=0.62\left(\mathrm{CH}_{2} \mathrm{Cl}_{2} / \mathrm{MeOH} 9: 1\right) ;{ }^{1} \mathrm{H}$ NMR $(400 \mathrm{MHz}$, [D $\left.\mathrm{D}_{6} \mathrm{DMSO}\right): \delta=13.64(\mathrm{~s}, 1 \mathrm{H}), 8.41(\mathrm{~s}, 1 \mathrm{H}), 7.55(\mathrm{~m}, 2 \mathrm{H}), 7.44$ 


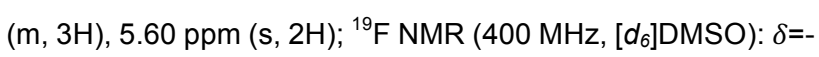
53.08 ppm; HRMS-ESI: $\mathrm{m} / \mathrm{z}$ calcd for $\mathrm{C}_{12} \mathrm{H}_{9} \mathrm{FN} \mathrm{N}_{4} \mathrm{O}[\mathrm{M}+\mathrm{Na}]^{+}$ 267.0653, found 267.0650 .

Compound 12: Compound $11(10 \mathrm{mg}, 0.04 \mathrm{mmol})$ and 4amino TEMPO (8) $(8.5 \mathrm{mg}, 0.05 \mathrm{mmol})$ were added to a solution of anhydrous DMF $(0.7 \mathrm{~mL})$ and $\mathrm{Et}_{3} \mathrm{~N}(18 \mu \mathrm{L}, 0.12$ $\mathrm{mmol}$ ) and heated at $100^{\circ} \mathrm{C}$ for $12 \mathrm{~h}$. The reaction mixture was cooled to room temperature and the solvent was evaporated in vacuo. The crude material was purified by flash column chromatography (silica gel) using a gradient elution $\left(\mathrm{CH}_{2} \mathrm{Cl}_{2}: 30 \% \mathrm{NH}_{3}\right.$ in $\mathrm{MeOH} ; 100: 0$ to $\left.90: 10\right)$ to give compound 12 as a pale-yellow solid (4 mg, 24\% yield). $R_{\mathrm{f}}=0.32$ $\left(\mathrm{CH}_{2} \mathrm{Cl}_{2} / \mathrm{MeOH}\right.$ 9:1); HRMS-ESI: $\mathrm{m} / \mathrm{z}$ calcd for $\mathrm{C}_{12} \mathrm{H}_{9} \mathrm{FN}_{4} \mathrm{O}$ $[\mathrm{M}+\mathrm{H}]^{+}$396.2268, found 396.2261.

Compound 6: To a solution of compound 12 (12 mg, 0.02 $\mathrm{mmol})$ in $\mathrm{MeOH}(5 \mathrm{~mL})$ was added $10 \% \mathrm{Pd} / \mathrm{C}(1 \mathrm{mg})$ under argon. The mixture was stirred under $\mathrm{H}_{2}$ gas (55 psi) at $22^{\circ} \mathrm{C}$ for $16 \mathrm{~h}$, the mixture was filtered through a pad of celite and the filtrate was concentrated in vacuo to yield compound 6 (7 $\mathrm{mg}, 80 \%$ yield). $R_{\mathrm{f}}=0.32\left(\mathrm{CH}_{2} \mathrm{Cl}_{2} / \mathrm{MeOH} 9: 1\right)$; HRMS-ESI: $\mathrm{m} / \mathrm{z}$ calcd for $\mathrm{C}_{14} \mathrm{H}_{21} \mathrm{~N}_{6} \mathrm{O}_{2}[\mathrm{M}+\mathrm{H}]^{+}$306.1799, found 306.1792.

\section{DNA and RNA synthesis and purification}

Phosphoramidites, CPG columns, 5-benzylthiotetrazole and acetonitrile for oligomer synthesis were purchased from ChemGenes Corp., USA. All other required reagents and solvents were purchased from Sigma-Aldrich. Unmodified oligonucleotides and oligonucleotides containing abasic sites were synthesized on an automated ASM800 DNA synthesizer (Biosset, Russia) using a trityl-off protocol and phosphoramidites with standard protecting groups on 1.0 umole scale (1000 $\AA$ CPG columns). The DNAs were deprotected from solid support using $33 \%$ aqueous ammonia solution at $55^{\circ} \mathrm{C}$ for $8 \mathrm{~h}$, whereas the general deprotection for RNAs was done using 1:1 solution (2 mL) of $\mathrm{CH}_{3} \mathrm{NH}_{2}(8 \mathrm{M}$ in $\mathrm{EtOH})$ and $\mathrm{NH}_{3}\left(33 \% \mathrm{w} / \mathrm{w}\right.$ in $\left.\mathrm{H}_{2} \mathrm{O}\right)$ at $65{ }^{\circ} \mathrm{C}$ for $45 \mathrm{~min}$. The solvent was removed in vacuo and the TBDMS-protecting groups were removed by incubation in $\mathrm{NEt}_{3} \cdot 3 \mathrm{HF}(600 \mu \mathrm{L})$ for $90 \mathrm{~min}$ at $55^{\circ} \mathrm{C}$ in DMF $(200 \mu \mathrm{L})$, followed by addition of water $(200 \mu \mathrm{L})$ and precipitation in 1-butanol. The oligonucleotides were purified by $20 \%$ denaturing polyacrylamide gel electrophoresis. The oligonucleotides were visualized by UV light and the bands were excised from the gel, crushed and extracted from the gel matrix with a Tris buffer $(250 \mathrm{mM} \mathrm{NaCl}$, $10 \mathrm{mM}$ Tris, $1 \mathrm{mM} \mathrm{Na} 2 \mathrm{EDTA}, \mathrm{pH}$ 7.5). The extracts were filtered through $0.45 \mu \mathrm{m}, 25 \mathrm{~mm}$ diameter $\mathrm{GD} / \mathrm{X}$ syringe filters (Whatman, USA) and desalted using Sep-Pak cartridges (Waters, USA), according to the manufacturer's instructions. After removing the solvent in vacuo, the oligomers were dissolved in de-ionized and sterilized water (200 $\mu \mathrm{L})$. Oligonucleotides were quantified using Beer's law and measurements of absorbance at $260 \mathrm{~nm}$, using extinction coefficients determined by using the WinLab oligonucleotide calculator (V2.85.04, PerkinEImer).

\section{EPR measurements}

Solutions for CW-EPR experiments were prepared by mixing aliquots of stock solutions of a single-stranded oligomer containing an abasic site, its complementary strand and the spin label (1:1.2:0.5). The solvent was evaporated in vacuo and the resulting residue was dissolved in a phosphate buffer (10 $\mu \mathrm{L} ; 10 \mathrm{mM} \mathrm{NaHPO}_{4}, 100 \mathrm{mM} \mathrm{NaCl}, 0.1 \mathrm{mM} \mathrm{Na}{ }_{2}$ EDTA, pH 7.0) and annealed: $90{ }^{\circ} \mathrm{C}$ for $2 \mathrm{~min}, 60^{\circ} \mathrm{C}$ for $5 \mathrm{~min}, 50{ }^{\circ} \mathrm{C}$ for $5 \mathrm{~min}, 22^{\circ} \mathrm{C}$ for $15 \mathrm{~min}$ and dried using a SpeedVac. The residue was dissolved in aqueous $30 \%$ ethylene glycol $(10 \mu \mathrm{L})$ containing $2 \%$ DMSO and placed in a $50 \mu \mathrm{L}$ quartz capillary (BLAUBRAND intraMARK) (final concentration of nucleic acid duplex $200 \mu \mathrm{M})$. The EPR spectra were recorded using 100200 scans on a MiniScope MS200 (Magnettech Germany) spectrometer $(100 \mathrm{kHz}$ modulation frequency, $1.0 \mathrm{G}$ modulation amplitude and $2.0 \mathrm{~mW}$ microwave power). Magnettech temperature controller M01 $\left( \pm 0.5^{\circ} \mathrm{C}\right)$ was used as a temperature regulator.

\section{Acknowledgment}

This research work was supported by the Icelandic Research Fund (141062-051). N. R. K. gratefully acknowledges the University of Iceland Research Fund for providing the doctoral research fellowship. We thank Dr. Subham Saha for critically reading this manuscript and $\mathrm{Dr}$. S. Jonsdottir for assistance in collecting analytic data for structural characterization of the compounds.

Keywords: ESR spectroscopy - EPR spectroscopy - DNA • $\mathrm{RNA} \cdot$ site-directed spin labeling (SDSL)

[1] a) O. Schiemann, T. F. Prisner, Q. Rev. Biophys. 2007, 40, 1-53; b) G. Z. Sowa, P. Z. Qin, Prog. Nucleic Acid Res. Mol. Biol. 2008, 82, 147197; c) L. Hunsicker-Wang, M. Vogt, V. J. Derose, Methods Enzymol. 2009, 468, 335-367; d) X. Zhang, P. Cekan, S. T. Sigurdsson, P. Z. Qin, Methods Enzymol. 2009, 469, 303-328; e) G. W. Reginsson, O. Schiemann, Vol. 39, Biochem. Soc. Trans., 2011, pp. 39, 128-129; f) I. Krstić, B. Endeward, D. Margraf, A. Marko, T. F. Prisner, in EPR Spectroscopy, Springer, 2011, pp. 159-198; g) Y. Ding, P. Nguyen, N. Tangprasertchai, C. Reyes, X. Zhang, P. Qin, Electron Paramagn. Reson. 2015, 24, 122-147.

[2] a) H.-J. Steinhoff, Frontiers Biosci. 2002, 7, 97-110; b) G. Jeschke, Annu. Rev. Phys. Chem. 2012, 63, 419-446; c) J. P. Klare, Biol. chem. 2013, 394, 1281-1300; d) E. R. Georgieva, Nanotechnol. Rev. 2017, 6, 75-92.

[3] a) W. L. Hubbell, D. S. Cafiso, C. Altenbach, Nat. Struct. Mol. Biol. 2000, 7, 735-739; b) P. Z. Qin, J. Iseri, A. Oki, Biochem. Biophys. Res. Commun. 2006, 343, 117-124; c) P. Nguyen, P. Qin, RNA 2012, 3, 6272 .

[4] a) J. Macosko, M. Pio, I. Tinoco, Y.-K. Shin, RNA 1999, 5, 1158-1166; b) N.-K. Kim, A. Murali, V. J. DeRose, Chem. Biol. 2004, 11, 939-948; c) H.-J. Steinhoff, Biol. Chem. 2004, 385, 913-920.

[5] a) P. P. Borbat, J. H. Davis, S. E. Butcher, J. H. Freed, J. Am. Chem. Soc. 2004, 126, 7746-7747; b) G. Jeschke, Y. Polyhach, Phys. Chem. Chem. Phys. 2007, 9, 1895-1910; c) G. W. Reginsson, O. Schiemann, Biochem. J. 2011, 434, 353-363; d) Z. Yang, Y. Liu, P. Borbat, J. L. 
Zweier, J. H. Freed, W. L. Hubbell, J. Am. Chem. Soc. 2012, 134, 9950-9952; e) O. Duss, M. Yulikov, G. Jeschke, F. H. Allain, Nat. Commun. 2014, 5, doi:10.1038/ncomms4669; f) D. Goldfarb, in Structural Information from Spin-Labels and Intrinsic Paramagnetic Centres in the Biosciences, Springer, 2012, pp. 163-204.

[6] a) A. Marko, V. Denysenkov, D. Margraf, P. Cekan, O. Schiemann, S. T. Sigurdsson, T. F. Prisner, J. Am. Chem. Soc. 2011, 133, 1337513379; b) T. F. Prisner, A. Marko, S. T. Sigurdsson, J. Magn. Reson. 2015, 252, 187-198; c) B. Endeward, A. Marko, V. Denysenkov, S. T. Sigurdsson, T. F. Prisner, Methods Enzymol. 2015, 564, 403-425; d) C. M. Grytz, A. Marko, P. Cekan, S. T. Sigurdsson, T. F. Prisner, Phys. Chem. Chem. Phys. 2016, 18, 2993-3002; e) C. M. Grytz, S. Kazemi, A. Marko, P. Cekan, P. Güntert, S. T. Sigurdsson, T. F. Prisner, Phys. Chem. Chem. Phys. 2017, doi:10.1039/C1037CP04997H.

[7] a) S. A. Shelke, S. T. Sigurdsson, Site-directed nitroxide spin labeling of biopolymers, Springer, 2011, pp. 121-162; b) S. A. Shelke, S. T. Sigurdsson, Eur. J. Org. Chem. 2012, 2291-2301; c) S. A. Shelke, S. T. Sigurdsson, in Modified Nucleic Acids, Springer, 2016, pp. 159-187.

[8] a) A. Spaltenstein, B. H. Robinson, P. B. Hopkins, J. Am. Chem. Soc. 1988, 110, 1299-1301; b) N. Barhate, P. Cekan, A. P. Massey, S. T. Sigurdsson, Angew. Chem. Int. Ed. 2007, 46, 2655-2658; c) C. Höbartner, G. Sicoli, F. Wachowius, D. B. Gophane, S. T. Sigurdsson, J. Org. Chem. 2012, 77, 7749-7754; d) D. B. Gophane, S. T. Sigurdsson, Chem. Commun. 2013, 49, 999-1001.

[9] O. Schiemann, N. Piton, J. Plackmeyer, B. E. Bode, T. F. Prisner, J. W. Engels, Nat. protoc. 2007, 2, 904-923.

[10] a) N. Piton, Y. Mu, G. Stock, T. F. Prisner, O. Schiemann, J. W. Engels, Nucleic Acids Res. 2007, 35, 3128-3143; b) P. Cekan, A. L. Smith, N. Barhate, B. H. Robinson, S. T. Sigurdsson, Nucleic Acids Res. 2008, 36, 5946-5954.

[11] a) P. Z. Qin, K. Hideg, J. Feigon, W. L. Hubbell, Biochemistry 2003, 42, 6772-6783; b) T. E. Edwards, S. T. Sigurdsson, Nat. Protoc. 2007, 2, 1954-1962; c) U. Jakobsen, S. A. Shelke, S. Vogel, S. T. Sigurdsson, J. Am. Chem. Soc. 2010, 132, 10424-10428; d) G. Sicoli, F. Wachowius, M. Bennati, C. Höbartner, Angew. Chem. Int. Ed. 2010, 49, 6443-6447; e) S. Saha, A. P. Jagtap, S. T. Sigurdsson, Chem. Commun. 2015, 51, 13142-13145; f) M. M. Haugland, A. H. ElSagheer, R. J. Porter, J. Peña, T. Brown, E. A. Anderson, J. E. Lovett, J. Am. Chem. Soc. 2016, 138, 9069-9072; g) K. Halbmair, J. Seikowski, I. Tkach, C. Höbartner, D. Sezer, M. Bennati, Chem. Sci. 2016, 7, 3172-3180.

[12] a) B. K. Sinha, C. F. Chignell, Life Sci. 1975, 17, 1829-1836; b) S.-J. Hong, L. H. Piette, Cancer Res. 1976, 36, 1159-1171; c) S.-J. Hong, L. Piette, Arch. Biochem. Biophys. 1978, 185, 307-315; d) I. Hurley, P. Osei-Gyimah, S. Archer, C. Scholes, L. Lerman, Biochemistry 1982, 21, 4999-5009; e) M. F. Ottaviani, N. D. Ghatlia, S. H. Bossmann, J. K. Barton, H. Duerr, N. J. Turro, J. Am. Chem. Soc. 1992, 114, 89468952; f) P. B. Dervan, Bioorg. Med. Chem. 2001, 9, 2215-2235.
[13] a) H. Atsumi, K. Maekawa, S. Nakazawa, D. Shiomi, K. Sato, M. Kitagawa, T. Takui, K. Nakatani, Chem. Lett. 2010, 39, 556-557; b) H. Atsumi, S. Nakazawa, C. Dohno, K. Sato, T. Takui, K. Nakatani, Chem. Commun. 2013, 49, 6370-6372.

[14] a) K. Yoshimoto, S. Nishizawa, M. Minagawa, N. Teramae, J. Am. Chem. Soc. 2003, 125, 8982-8983; b) B. Rajendar, S. Nishizawa, N. Teramae, Org. Biomol. Chem. 2008, 6, 670-673.

[15] a) P. Belmont, C. Chapelle, M. Demeunynck, J. Michon, P. Michon, J. Lhomme, Bioorg. Med. Chem. Lett. 1998, 8, 669-674; b) F. Thomas, J. Michon, J. Lhomme, Biochemistry 1999, 38, 1930-1937.

[16] a) S. A. Shelke, S. T. Sigurdsson, Angew. Chem. Int. Ed. 2010, 49, 7984-7986; b) S. A. Shelke, S. T. Sigurdsson, Nucleic Acids Res. 2012, 40, 3732-3740; c) S. A. Shelke, G. B. Sandholt, S. T. Sigurdsson, Org. Biomol. Chem. 2014, 12, 7366-7374.

[17] G. W. Reginsson, S. A. Shelke, C. Rouillon, M. F. White, S. T. Sigurdsson, O. Schiemann, Nucleic Acids Res. 2013, 41, e11.

[18] N. R. Kamble, M. Gränz, T. F. Prisner, S. T. Sigurdsson, Chem. Commun. 2016, 52, 14442-14445.

[19] D. Reid, S. Bottle, Chem. Commun. 1998, 1907-1908.

[20] R. C. Moschel, A. E. Pegg, M. E. Dolan, M.-Y. Chae, US005958932A, 1999.

[21] I. R. Hardcastle, C. E. Arris, J. Bentley, F. T. Boyle, Y. Chen, N. J. Curtin, J. A. Endicott, A. E. Gibson, B. T. Golding, R. J. Griffin, J. Med. Chem. 2004, 47, 3710-3722.

[22] a) F. Wyers, A. Sentenac, P. Fromageot, Eur. J. Biochem. 1973, 35, 270-281; b) I. Sidorenkov, N. Komissarova, M. Kashlev, Mol. Cell 1998, 2, 55-64; c) E. Zamaratski, P. Pradeepkumar, J. Chattopadhyaya, J. Biochem. Biophys. Methods 2001, 48, 189-208; d) M. Nowotny, S. A. Gaidamakov, R. J. Crouch, W. Yang, Cell 2005, 121, 1005-1016; e) A. Rich, J. Biol. Chem. 2006, 281, 7693-7696; f) C. Ohle, R. Tesorero, G. Schermann, N. Dobrev, I. Sinning, T. Fischer, Cell 2016, 167, 10011013.

[23] T. Aboul-Fadl, Curr. Med. Chem. 2005, 12, 2193-2214.

[24] a) O. Y. Fedoroff, M. Salazar, B. R. Reid, J. Mol. Biol. 1993, 233, 509523; b) B. M. Znosko, T. W. Barnes, T. R. Krugh, D. H. Turner, J. Am. Chem. Soc. 2003, 125, 6090-6097.

[25] a) G. L. Conn, T. Brown, G. A. Leonard, Nucleic Acids Res. 1999, 27, 555-561; b) Y. Xiong, M. Sundaralingam, Nucleic Acids Res. 2000, 28 , 2171-2176; c) M. L. Kopka, L. Lavelle, G. W. Han, H.-L. Ng, R. E. Dickerson, J. Mol. Biol. 2003, 334, 653-665; d) G. W. Han, M. L. Kopka, D. Langs, M. R. Sawaya, R. E. Dickerson, Proc. Natl. Acad. Sci. U. S. A. 2003, 100, 9214-9219.

[26] D. Andreatta, S. Sen, J. L. Pérez Lustres, S. A. Kovalenko, N. P. Ernsting, C. J. Murphy, R. S. Coleman, M. A. Berg, J. Am. Chem. Soc. 2006, 128, 6885-6892.

[27] a) T. D. Lee, J. F. Keana, J. Org. Chem. 1975, 40, 3145-3147; b) Y. Li, X. Lei, X. Li, R. G. Lawler, Y. Murata, K. Komatsu, N. J. Turro, Chem. Commun. 2011, 47, 12527-12529. 
Entry for the Table of Contents (Please choose one layout)

Layout 1:

\section{FULL PAPER}

Binding without bonding: Isoindolinederived purine spin-labels bind efficiently to abasic sites of duplex DNA and RNA when they can form hydrogen bonds to the orphan base on the opposing strand; the adenine-derived spin label $\mathbf{5}$ pairs with uracil (or thymine) and the guaninederivative Ǵ pairs with cytosine. Ǵ also binds to abasic sites in DNA-RNA hybrid duplexes and shows a minimal flankingsequence effect upon binding to abasic sites in RNA.

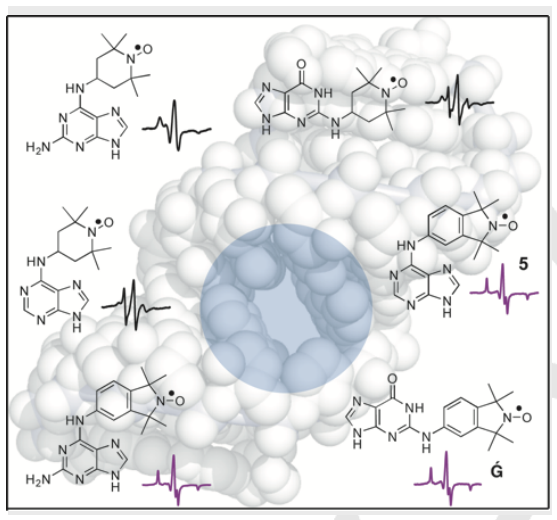

Nilesh R. Kamble and Snorri Th. Sigurdsson $^{[a]}$

Page No. - Page No.

Title: Noncovalent spin labeling

Layout 2:

\section{FULL PAPER}

((Insert TOC Graphic here; max. width: $11.5 \mathrm{~cm}$; max. height: $2.5 \mathrm{~cm})$ )

Author(s), Corresponding Author(s)*

Page No. - Page No.

Title

Text for Table of Contents 


\title{
Supporting Information
}

\section{Purine-derived nitroxides for noncovalent spin-labeling of abasic sites in duplex nucleic acids}

\author{
Nilesh R. Kamble and Snorri Th. Sigurdsson* \\ University of Iceland, Department of Chemistry, Science Institute, Dunhaga 3, 107 \\ Reykjavik, Iceland. E-mail: snorrisi@hi.is; Fax: +354 5528911; Tel: +354 5254801
}

\section{Table of Contents}

List of abbreviations

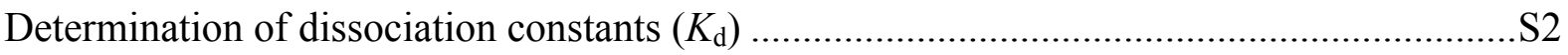

Binding affinity of $\mathbf{G}$ to DNA-DNA, RNA-RNA and DNA-RNA duplexes .........................S3

Effect of flanking sequence on noncovalent spin-labeling of RNA with Ǵ .........................S3

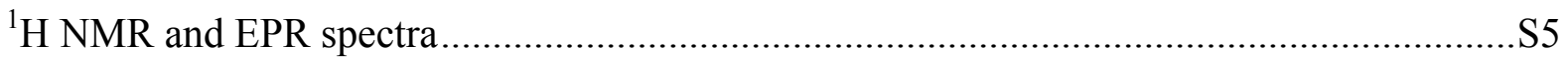

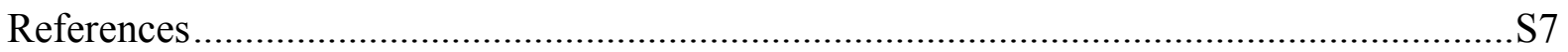




\section{List of abbreviations}

$\begin{array}{ll}\text { CW } & \text { continuous-wave } \\ \text { EPR } & \text { electron paramagnetic resonance } \\ \text { NMR } & \text { nuclear magnetic resonance } \\ \text { A } & \text { adenine } \\ \text { C } & \text { cytosine } \\ \text { G } & \text { guanine } \\ \text { T } & \text { thymine } \\ \text { U } & \text { uracil }\end{array}$

\section{Determination of dissociation constants $\left(K_{\mathrm{d}}\right)$}

An in-house MATLAB-based program was used to calculate dissociation constants $\left(K_{\mathrm{d}}\right){ }^{[1]}$ The EPR spectrum of the $\mathbf{G}$ and the EPR spectrum of $\mathbf{G}$ in the presence of duplex nucleic acid containing an abasic site were double-integrated ${ }^{[2]}$ and normalized with respect to their area. The normalized spectrum of $\mathbf{G}$ was fractionally subtracted from the normalized spectrum of $\mathbf{G}$ in the presence of a duplex nucleic acid to get the visually best fit to a fully bound spectrum. The fraction value $\propto$ was used to calculate the dissociation constant $\left(K_{\mathrm{d}}\right)$ using the following equation:

$$
K_{\mathrm{d}}=\frac{[\mathrm{Y}-(1-\propto) * \mathrm{X}][\propto * \mathrm{X}]}{(1-\propto) * \mathrm{X}}
$$

, where $\mathrm{X}$ is a initial concentration of the spin label and $\mathrm{Y}$ is a initial concentration of the duplex nucleic acid that contains an abasic site. 


\section{Binding affinity of Ǵ to DNA-DNA, RNA-RNA and DNA-RNA duplexes}

The binding affinities of Ǵ to all the duplexes (DNA-DNA, RNA-RNA and DNA-RNA) at 0 ${ }^{\circ} \mathrm{C}$ were compared by plotting a bar graph of the dissociation constants $\left(K_{\mathrm{d}}\right)$ of $\mathbf{G}$ to each duplex. Ǵ showed extensive binding to the RNA duplex $\left(K_{\mathrm{d}}=1.46 \times 10^{-7} \mathrm{M}\right)$, the second highest binding to the DNA-RNA duplex $\left(K_{\mathrm{d}}=9.75 \times 10^{-7} \mathrm{M}\right)$, and the least binding to the DNA duplex $\left(K_{\mathrm{d}}=60.17 \times 10^{-7} \mathrm{M}\right)$.

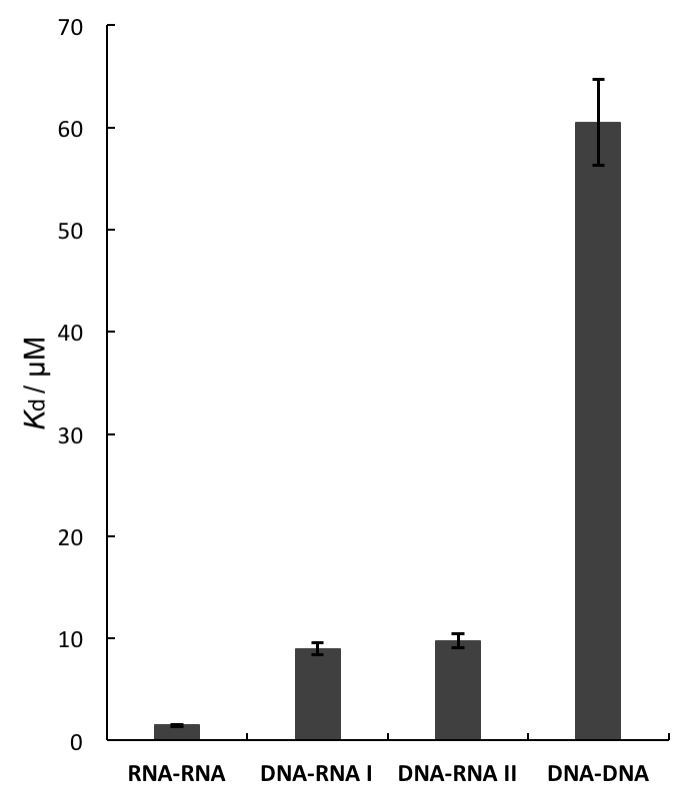

Figure S1. A plot of the dissociation constants $\left(K_{\mathrm{d}}\right)$ of $\mathbf{G}$-binding to RNA-RNA, DNA-RNA (I and II) and DNADNA duplexes containing an abasic site opposite cytosine $(\mathrm{C})$ at $0{ }^{\circ} \mathrm{C}$.

\section{Effect of flanking sequence on noncovalent spin-labeling of RNA with Ǵ}

Figure S2 shows the EPR spectra that were used to determine the effect of flanking sequence on noncovalent spin-labeling of RNA duplex with Ǵ. A series of sixteen 14-mer RNA duplexes were prepared and incubated with Ǵ. Only a minor variation in the extent of binding between the flanking sequences was observed. 


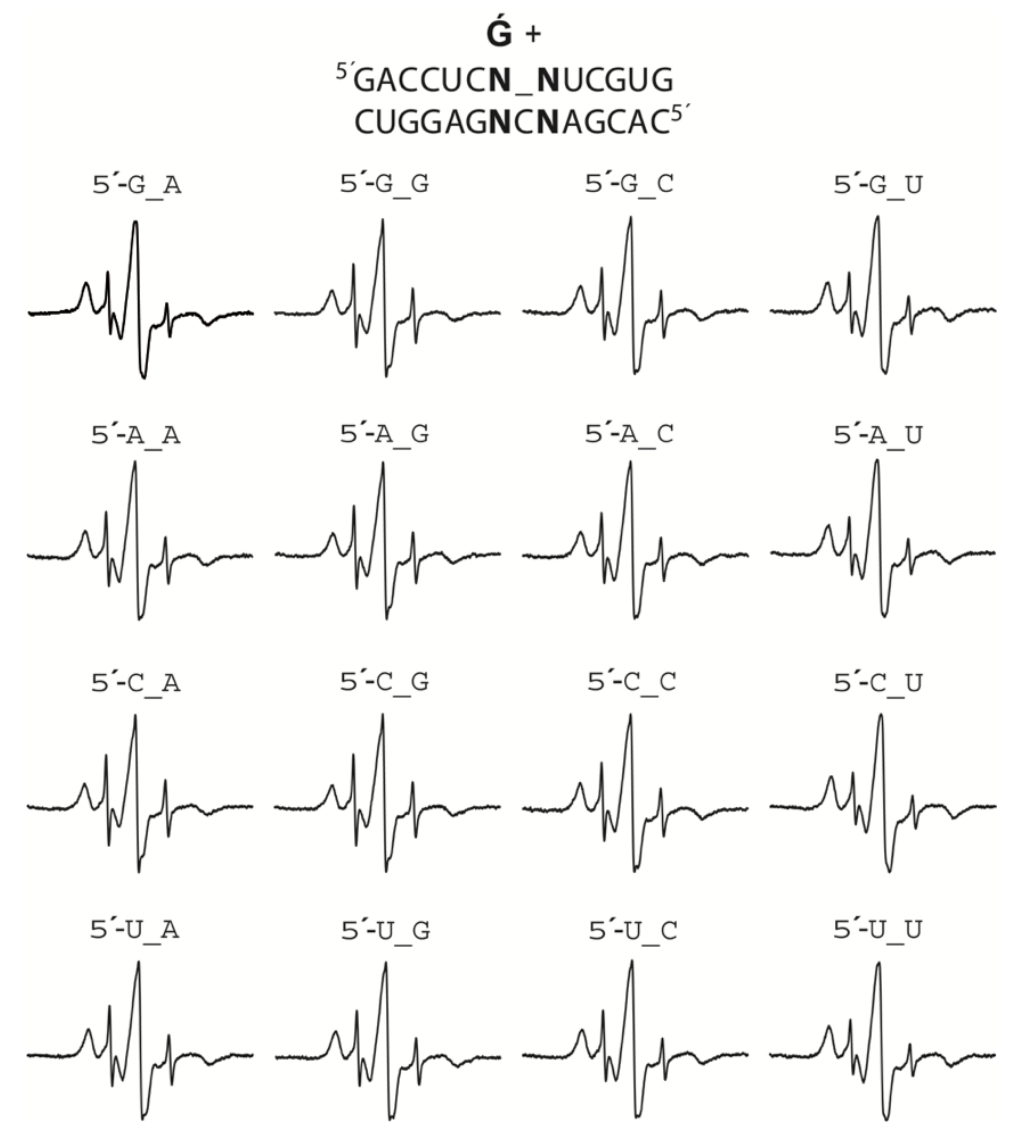

Figure S2. EPR spectra of $\mathbf{G}(200 \mu \mathrm{M})$ in the presence of duplex RNAs $(400 \mu \mathrm{M})$ containing different flanked bases to the abasic site "_." EPR spectra were recorded in a phosphate buffer (pH 7.0) containing $30 \%$ ethylene glycol and $2 \%$ DMSO at $20{ }^{\circ} \mathrm{C}$.

The binding extent of the spin label was quantified by determining the dissociation constants $\left(K_{\mathrm{d}}\right)$ at $20^{\circ} \mathrm{C}$, which were plotted as a function of the flanking sequence (Figure S8). The effects that the flanking sequences have on binding of the spin label were minimal within a factor of two.

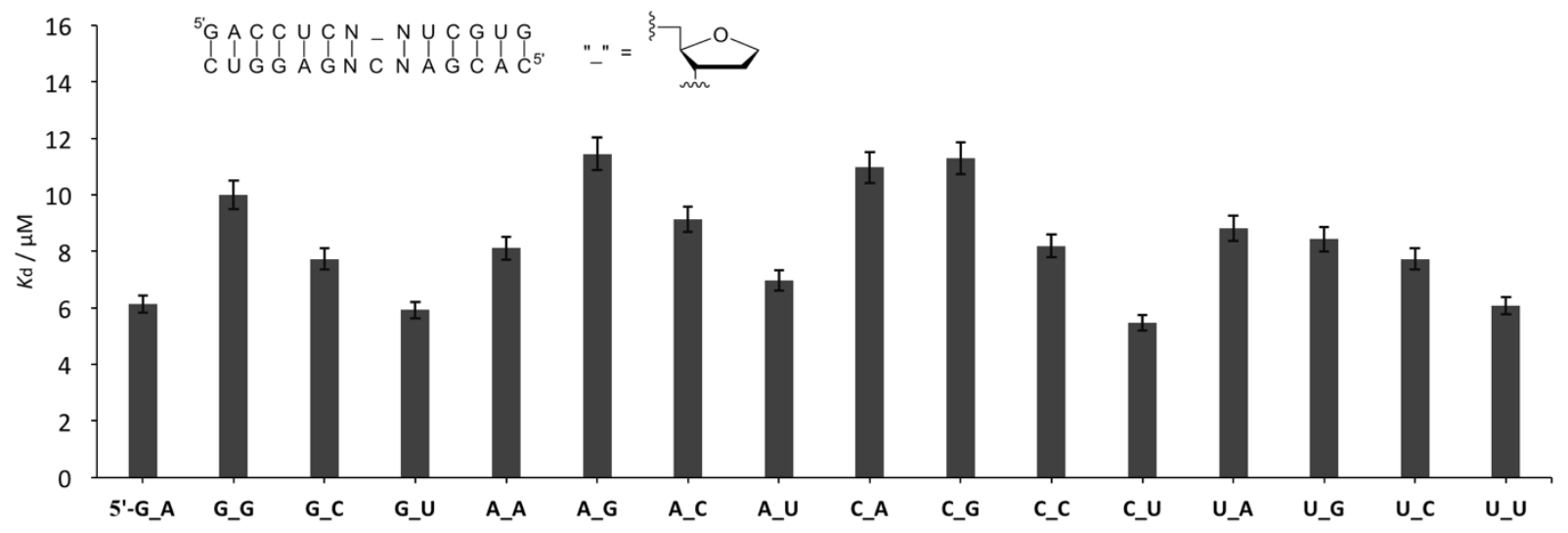

Figure S3. A plot of the dissociation constants $\left(K_{\mathrm{d}}\right)$ of Ǵ-binding to duplex RNA containing an abasic site (denoted by “_") as a function of the flanking sequence at $20^{\circ} \mathrm{C}(200 \mu \mathrm{M}$ RNA duplex, $100 \mu \mathrm{M} \mathbf{G}$ and a phosphate buffer, $\mathrm{pH} 7.0$, containing 30\% ethylene glycol and 2\% DMSO). 


\section{${ }^{1} \mathrm{H}$ NMR and EPR spectra}

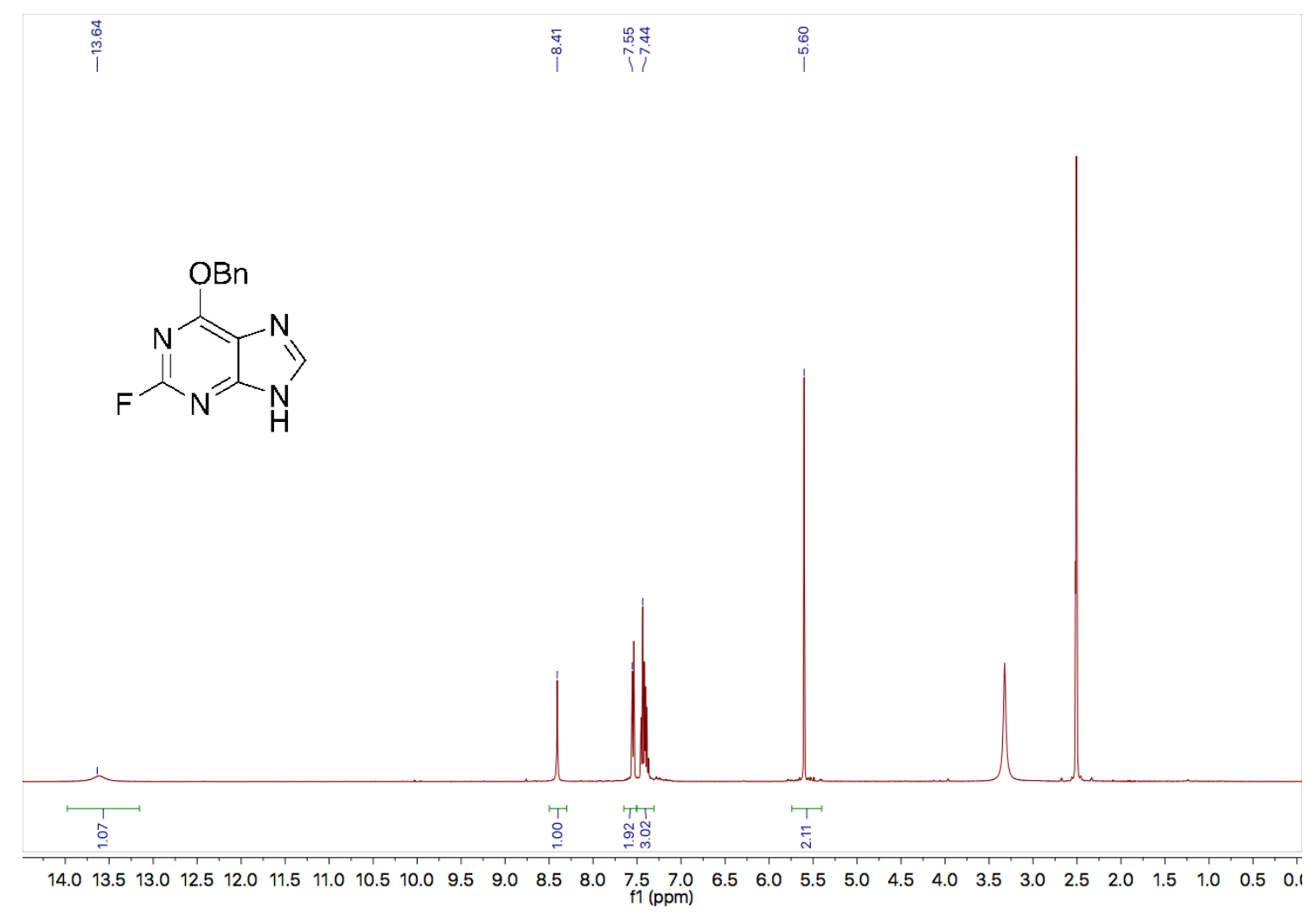

Figure S4. ${ }^{1}$ H NMR spectrum of compound 11.

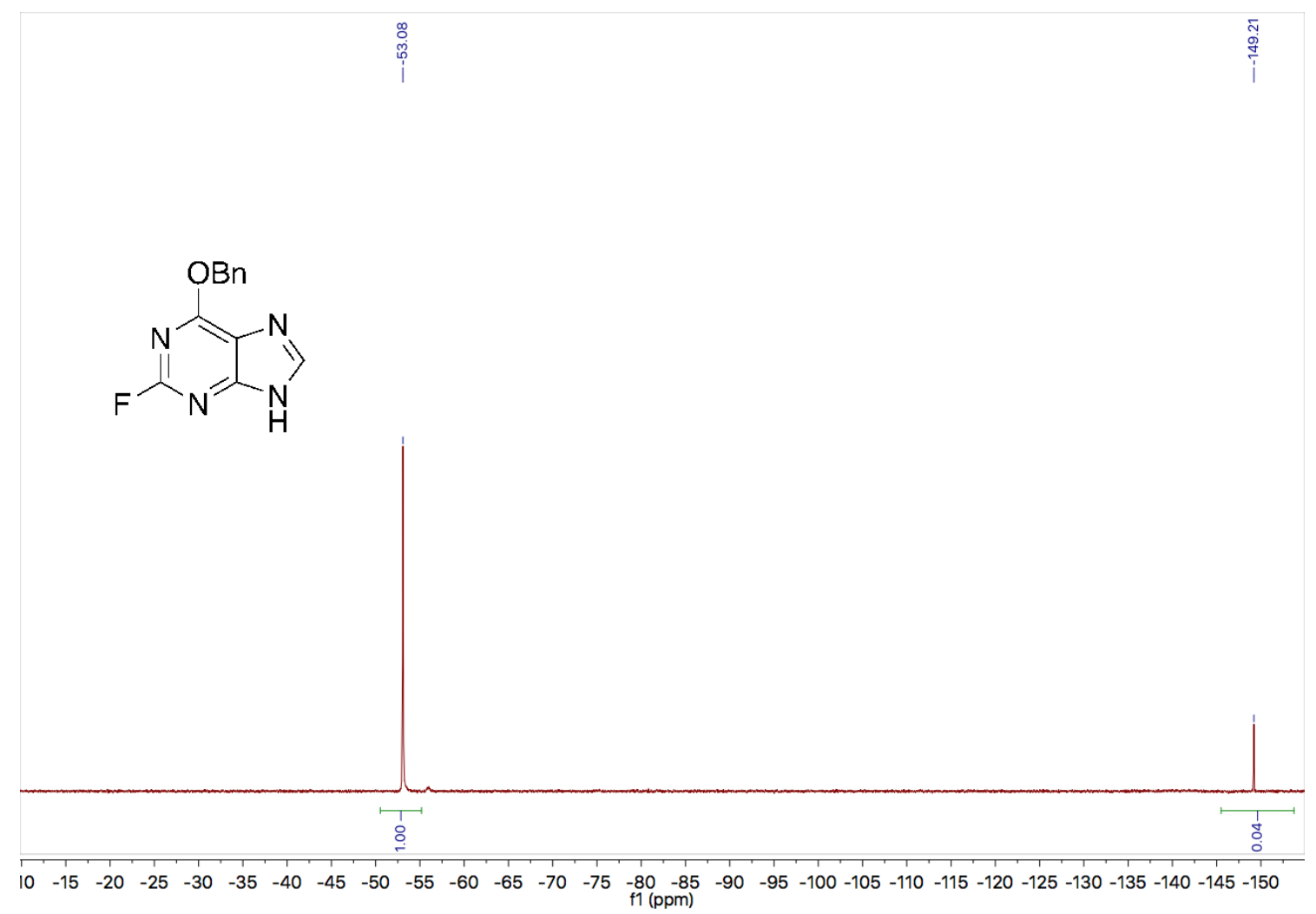

Figure S5. ${ }^{1}$ H NMR spectrum of compound 11. 
<smiles>CC1(C)CC(Nc2nc(N)nc3[nH]cnc23)CC(C)(C)N1O</smiles>

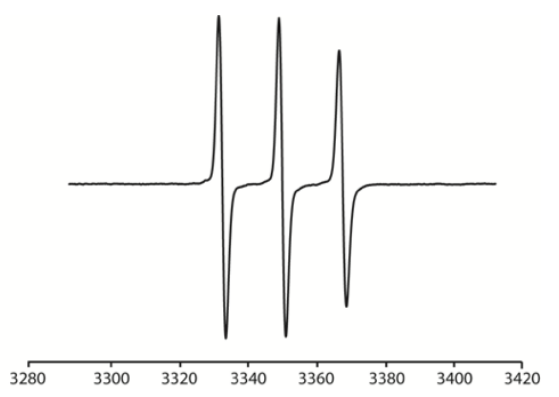

Figure S6. EPR spectrum of compound 2 in EtOH.<smiles>CC1(C)c2ccc(Nc3nc(N)nc4[nH]cnc34)cc2C(C)(C)N1[O-]</smiles>

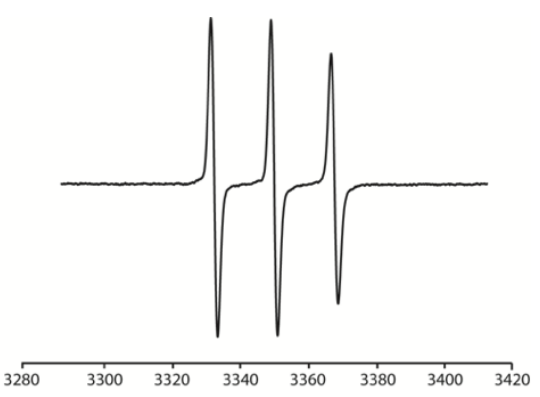

Figure S7. EPR spectrum of compound 3 in EtOH.<smiles>CC1(C)CC(Nc2ncnc3[nH]cnc23)CC(C)(C)N1O</smiles>

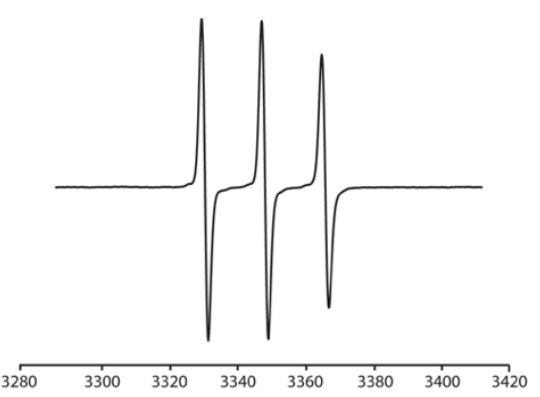

Figure S8. EPR spectrum of compound 4 in EtOH.<smiles>CC1(C)c2ccc(Nc3ncnc4[nH]cnc34)cc2C(C)(C)N1[O-]</smiles>

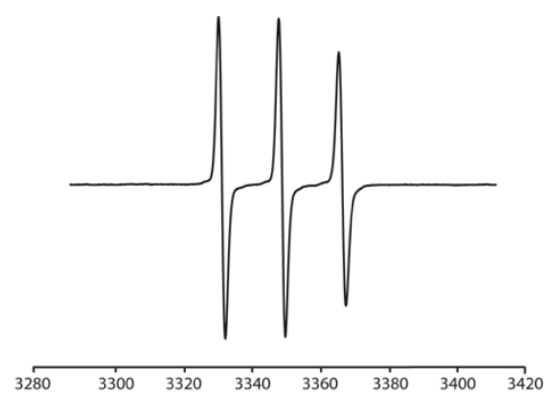

Figure S9. EPR spectrum of compound 5 in EtOH.<smiles></smiles>

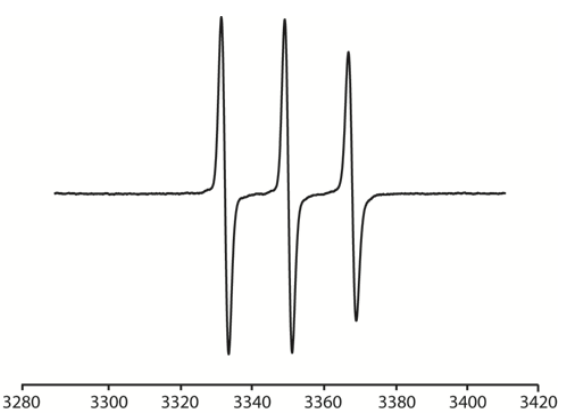

Figure S10. EPR spectrum of compound 6 in EtOH. 


\section{References}

[1] S. A. Shelke, S. T. Sigurdsson, Angew. Chem. Int. Ed. 2010, 49, 7984-7986.

[2] a) V. Zinchenko, Meas.Tech. 1975, 18, 741-742; b) A. Schick, H. Rager, Appl. Magn. Reson. 1993, 4, 367-375. 

Paper III 



\title{
Quantitative UPLC-MS/MS assay of urinary 2,8-dihydroxyadenine for diagnosis and management of adenine phosphoribosyltransferase deficiency
}

\author{
Margret Thorsteinsdottir ${ }^{\mathrm{a}, \mathrm{b}, *}$, Unnur A. Thorsteinsdottir ${ }^{\mathrm{a}, \mathrm{b}}$, Finnur F. Eiriksson ${ }^{\mathrm{a}, \mathrm{b}}$, \\ Hrafnhildur L. Runolfsdottir ${ }^{a}$, Inger M.Sch. Agustsdottir ${ }^{c}$, Steinunn Oddsdottir $^{d}$, \\ Baldur B. Sigurdsson ${ }^{\mathrm{b}, \mathrm{e}}$, Hordur K. Hardarson ${ }^{\mathrm{a}}$, Nilesh R. Kamble ${ }^{\mathrm{a}}$, Snorri Th. Sigurdsson ${ }^{\mathrm{a}}$, \\ Vidar O. Edvardsson ${ }^{\mathrm{a}, \mathrm{c}}$, Runolfur Palsson ${ }^{\mathrm{a}, \mathrm{f}}$ \\ a University of Iceland, Reykjavik, Iceland \\ ${ }^{\mathrm{b}}$ ArcticMass, Reykjavik, Iceland \\ c Childrenís Medical Center, Landspitali - The National University Hospital of Iceland, Reykjavik, Iceland \\ d Department of Clinical Biochemistry, Landspitali - The National University Hospital of Iceland, Reykjavik, Iceland \\ e Center for Biomedicine, European Academy of Bolzano/Bozen, Bolzano, Italy \\ ${ }^{\mathrm{f}}$ Division of Nephrology, Landspitali - The National University Hospital of Iceland, Reykjavik, Iceland
}

\section{A R T I C L E I N F O}

\section{Article history:}

Received 27 May 2016

Received in revised form 9 September 2016

Accepted 13 September 2016

Available online 14 September 2016

\section{Keywords:}

APRT deficiency

Clinical mass spectrometry

Chemometrics

D-optimal design

Therapeutic drug monitoring

\begin{abstract}
A B S T R A C T
Adenine phosphoribosyltransferase (APRT) deficiency is a hereditary disorder that leads to excessive urinary excretion of 2,8-dihydroxyadenine (DHA), causing nephrolithiasis and chronic kidney disease. Treatment with allopurinol or febuxostat reduces DHA production and attenuates the renal manifestations. Assessment of DHA crystalluria by urine microscopy is used for therapeutic monitoring, but lacks sensitivity. We report a high-throughput assay based on ultra-performance liquid chromatography coupled to tandem mass spectrometry (UPLC-MS/MS) for quantification of urinary DHA.

The UPLC-MS/MS assay was optimized by a chemometric approach for absolute quantification of DHA, utilizing isotopically labeled DHA as an internal standard. Experimental screening was conducted with D-optimal design and optimization of the DHA response was performed with central composite face design and related to the peak area of DHA using partial least square regression. Acceptable precision and accuracy of the DHA concentration were obtained over a calibration range of 100 to $5000 \mathrm{ng} / \mathrm{mL}$ on three different days. The intra- and inter-day accuracy and precision coefficients of variation were well within $\pm 15 \%$ for quality control samples analyzed in replicates of six at three concentration levels. Absolute quantification of DHA in urine samples from patients with APRT deficiency was achieved wihtin $6.5 \mathrm{~min}$. Measurement of DHA in 24 h urine samples from three patients with APRT deficiency, diluted 1:15 $(v / v)$ with $10 \mathrm{mM}$ ammonium hydroxide $\left(\mathrm{NH}_{4} \mathrm{OH}\right)$, yielded a concentration of 3021, 5860 and $10563 \mathrm{ng} / \mathrm{mL}$ and $24 \mathrm{~h}$ excretion of 816,1327 and $1649 \mathrm{mg}$, respectively. A rapid and robust UPLC-MS/MS assay for absolute quantification of DHA in urine was successfully developed. We believe this method will greatly facilitate diagnosis and management of patients with APRT deficiency.
\end{abstract}

(c) 2016 Elsevier B.V. All rights reserved.

Abbreviations: APRT, adenine phosphoribosyltransferase; CCF, central composite face; CE, capillary electrophoresis; CID, collision induced dissociation; CKD, chronic

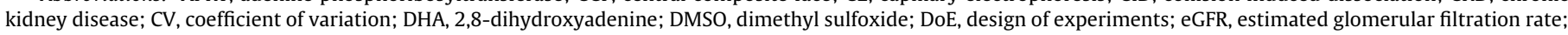

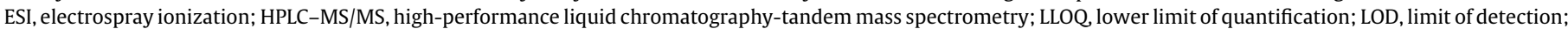

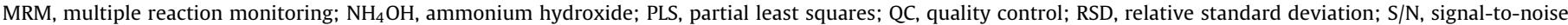
ratio; UPLC-MS/MS, ultra-performance liquid chromatography-tandem mass spectrometry; UV, ultraviolet.

* Corresponding author at: University of Iceland, Reykjavik, Iceland.

E-mail addresses: margreth@hi.is (M. Thorsteinsdottir), u.thorsteinsdottir@gmail.com (U.A. Thorsteinsdottir), finnur@arcticmass.is

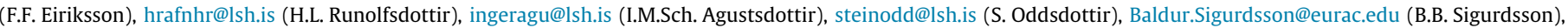
hordurkari@gmail.com (H.K. Hardarson), nrk2@hi.is (N.R. Kamble), snorrisi@hi.is (S.Th. Sigurdsson), vidare@lsh.is (V.O. Edvardsson), runolfur@lsh.is (R. Palsson). 


\section{Introduction}

Adenine phosphoribosyltransferase (APRT) deficiency (OMIM 102600) is a rare autosomal recessive disorder of purine metabolism, primarily manifested by nephrolithiasis and chronic kidney disease (CKD) [1-3]. The absence of functional APRT prevents recycling of adenine, which in turn is oxidized by xanthine dehydrogenase to the poorly soluble 2,8-dihydroxyadenine (DHA). Precipitation of DHA in the kidneys leads to progressive crystal-associated tubulointerstitial nephropathy and urinary stone formation [4-8]. Since APRT deficiency can be successfully treated with the xanthine dehydrogenase inhibitors allopurinol and febuxostat, early diagnosis and timely initiation of pharmacotherapy prevents stone formation and irreversible loss of kidney function [4-8]. Although the characteristic round, brown DHA crystals are usually readily detected by urine microscopy, they are frequently missed or misidentified [4,5,9]. Infrared spectrophotometry and $x$-ray crystallography are the recommended methods for detecting DHA in urinary calculi $[1,10]$. Nevertheless, the authors have observed several cases of false identification of DHA in kidney stone specimens using these techniques. Thus, the diagnosis of APRT deficiency still relies on the demonstration of absent APRT activity in red cell lysates or biallelic pathogenic variants in the APRT gene $[11,12]$. Monitoring of pharmacological therapy is currently based on microscopic evaluation of crystalluria, with the absence of DHA crystals considered indicative of adequate therapy [12]. Several methods for analysis of urinary DHA concentration have previously been described in the literature, including high-performance liquid chromatography (HPLC) coupled to a multichannel ultraviolet detector [13], capillary electrophoresis (CE) [14-17] and HPLC coupled to tandem mass spectrometry (HPLC-MS/MS) [18]. None of these methods have been established for use in clinical practice. Hence, a rapid and accurate clinical assay for DHA detection is needed to enhance the diagnosis and therapeutic monitoring of patients with APRT deficiency.

Since HPLC-MS/MS has proved to be a highly reliable method for the identification and quantification of various biomarkers [19-21], we developed and report herein a novel ultra-performance liquid chromatography-tandem mass spectrometry (UPLC-MS/MS) assay for absolute quantification of urinary DHA, employing an isotopically labeled DHA as an internal standard. Optimization of the UPLC-MS/MS quantification method was carried out using a chemometric approach [22-25]. The assay was pre-validated in terms of selectivity, sensitivity, concentration function, accuracy, precision, carryover, stability and matrix effect for diluted urine samples [26,27].

\section{Experimental}

\subsection{Chemicals and reagents}

DHA (95\% pure), manufactured by Sigma-Aldrich (Taufkirchen, Germany), but no longer commercially available, was kindly provided by L. Fairbanks, Purine Research Laboratory, St Thomas' Hospital, London, UK. Adenine (99.6\% pure), adenosine (100\% pure), 2-deoxyadenosine (99.9\% pure), hypoxanthine (99.6\% pure), inosine (99.2\% pure), 2-deoxyinosine (99.8\% pure), uric acid $(99.3 \%$ pure), acetonitrile (gradient grade), methanol (gradient grade), ammonia (25\%), ammonium acetate (reagent grade), ammonium hydroxide $\left(\mathrm{NH}_{4} \mathrm{OH}\right.$, reagent grade), formic acid (reagent grade) and dimethyl sulfoxide (DMSO, Chromasolv grade) were purchased from Sigma-Aldrich (Taufkirchen, Germany). Deionized water was produced by the Millipore ${ }^{\circledR}$ technique. 2-Deoxyguanosine-13C (15N2) (98\% pure) was obtained from Santa Cruz (Dallas, TX, USA) and applied as an internal standard for purines during method development.

\subsection{Internal standard for $D H A$}

In order to perform absolute quantification of DHA in urine samples, an isotopically labeled internal standard was required. 2,8-Dihydroxyadenine-2- ${ }^{13} \mathrm{C}-1,3-{ }^{15} \mathrm{~N}_{2}$ (DHA-2- ${ }^{13} \mathrm{C}-1,3-{ }^{15} \mathrm{~N}_{2}$ ) was synthesized by our group, following a previously reported protocol $[28,29]$, using thiourea- ${ }^{13} \mathrm{C},{ }^{15} \mathrm{~N}_{2}$ as a starting material.

\subsection{Preparation of solutions and samples for UPLC-MS/MS analysis}

Standard stock solutions were prepared in $100 \mathrm{mM} \mathrm{NH}_{4} \mathrm{OH}$ at a concentration of $100 \mu \mathrm{g} / \mathrm{mL}$ for DHA, adenine and 2deoxyadenosine, $200 \mu \mathrm{g} / \mathrm{mL}$ for adenosine, hypoxanthine, inosine, 2-deoxyinosine, and uric acid, and $1 \mathrm{mg} / \mathrm{mL}$ for DHA-2- ${ }^{13} \mathrm{C}-1,3-$ ${ }^{15} \mathrm{~N}_{2}$ and 2-deoxyguanosine ${ }^{13} \mathrm{C},{ }^{15} \mathrm{~N}_{2}$. Urine samples donated by healthy volunteers, diluted 1:15 $(v / v)$ with $10 \mathrm{mM} \mathrm{NH}_{4} \mathrm{OH}$, were used as a blank matrix. An intermediate working solution was prepared in $10 \mathrm{mM} \mathrm{NH}_{4} \mathrm{OH}$ at the concentration of $10 \mu \mathrm{g} / \mathrm{mL}$ for DHA, adenine, adenosine, 2-deoxyadenosine, hypoxanthine, inosine, 2-deoxyinosine, uric acid and 2-deoxyguanosine ${ }^{13} \mathrm{C},{ }^{15} \mathrm{~N}_{2}$. This intermediate working solution was diluted 1:100 $(v / v)$ with the blank matrix, producing a $1000 \mathrm{ng} / \mathrm{mL}$ solution of each analyte for use during the design of experiments (DoE). A working solution of the internal standard, DHA-2- ${ }^{13} \mathrm{C}-1,3-{ }^{15} \mathrm{~N}_{2}(8 \mu \mathrm{g} / \mathrm{mL})$ was prepared in $10 \mathrm{mM} \mathrm{NH}_{4} \mathrm{OH}$. All solutions were stored at $-20^{\circ} \mathrm{C}$. For the quantification of DHA, a calibration standard and QC samples were prepared fresh each day by adding the intermediate working solutions prepared in $10 \mathrm{mM} \mathrm{NH}_{4} \mathrm{OH}$ at an analyte concentration of $0.04,0.08,0.16,0.2,0.3,0.5,0.6,0.8,1.2,2.0,4.0,6.0$ and $10.0 \mu \mathrm{g} / \mathrm{mL}$ as well as by adding the internal standard working solution by proper dilution with the blank matrix. The calibration points were selected at the DHA concentrations of $100,150,250,400,600,1000$, $3000,5000 \mathrm{ng} / \mathrm{mL}$ and $3 \mathrm{QC}$ samples at the concentrations of 300 , $800,2000 \mathrm{ng} / \mathrm{mL}$ for DHA and $8 \mu \mathrm{g} / \mathrm{mL}$ for the internal standard.

\subsection{Multivariate experimental design for the UPLC-MS/MS assay}

Waters ACQUITY UPLC device coupled to a Quattro Premier ${ }^{\mathrm{TM}} \mathrm{XE}$ triple quadrupole mass spectrometer (Waters Corporation, Milford, MA) was utilized for the analysis. Multiple reaction monitoring (MRM) in both negative and positive electrospray ionization (ESI) modes was employed and the fragmentation behavior of each compound characterized using collision-induced dissociation (CID). The MRM transition of each analyte is presented in Table 1. Nitrogen was used as a desolvation and cone gas and high purity argon as a collision gas. Source temperature and desolvation gas temperature were set at $130^{\circ} \mathrm{C}$ and $400^{\circ} \mathrm{C}$, respectively. The analytical column, Acquity HSS T3 $(1.8 \mu \mathrm{m}, 100 \times 2.1 \mathrm{~mm})$ (Waters Corporation, Wexford, Ireland), was maintained at $35^{\circ} \mathrm{C}$. The injection volume was 5 or $10 \mu \mathrm{L}$. D-optimal design with interaction model (MODDE Pro 11, Data Analytics Solutions, MKS Instruments AB, Umea, Sweden), consisting of 3 quantitative and 3 qualitative factors, was generated to determine significant variables for a UPLC-MS/MS screening assay of DHA in human urine. The assay was designed to include simultaneous measurement of DHA, adenine, adenosine, 2-deoxyadenosine, hypoxanthine, inosine, 2-deoxyinosine, and uric acid to ensure adequate separation between all analytes. Capillary voltage, gradient steepness, type of gradient slope, flow rate, and different composition of the mobile phase were optimized and related to the UPLC-MS/MS responses, utilizing partial least squares (PLS) regression. Mobile phase A consisted of MQ water containing $0.1 \%(v / v)$ formic acid $(\mathrm{pH} 2.8)$ or MQ water with 
Table 1

MRM transitions for the analytes in both positive and negative ESI.

\begin{tabular}{|c|c|c|c|c|c|}
\hline \multirow[t]{2}{*}{ Analyte } & \multirow[t]{2}{*}{ MW [g/mol] } & \multicolumn{2}{|c|}{ Negative ESI $[m / z]$} & \multicolumn{2}{|c|}{ Positive ESI $[m / z]$} \\
\hline & & Precursor ion & Product ion & Precursor ion & Product ion \\
\hline 2,8-Dihydroxyadenine & 167.1 & 165.6 & 122.7 & 168.1 & 125.0 \\
\hline Adenine & 135.1 & 133.9 & 106.9 & 136.0 & 119.0 \\
\hline Adenosine & 267.2 & 311.9 & 133.7 & 268.2 & 136.0 \\
\hline 2-Deoxyadenosine & 251.2 & 250.2 & 133.9 & 252.3 & 136.0 \\
\hline Hypoxanthine & 136.1 & 134.5 & 91.6 & 137.0 & 110.0 \\
\hline Inosine & 268.2 & 266.9 & 134.7 & 269.3 & 137.0 \\
\hline 2-Deoxyinosine & 252.2 & 251.0 & 134.8 & 253.3 & 137.0 \\
\hline Uric acid & 168.1 & 166.6 & 123.8 & 169.0 & 141.0 \\
\hline 2,8-Dihydroxyadenine-2- ${ }^{13} \mathrm{C}-1,3-{ }^{15} \mathrm{~N}_{2}$ & 170.1 & & & 170.7 & 152.9 \\
\hline 2-Deoxyguanosine $-{ }^{13} \mathrm{C},{ }^{15} \mathrm{~N}_{2}$ & 270.2 & & & 271.3 & 155.0 \\
\hline
\end{tabular}

ESI, electrospray ionization.

Table 2

Experimental factors and settings for the multivariate designs of experiments.

\begin{tabular}{llll}
\hline Design & Qualitative factor & Settings & \\
\hline D-optimal design & pH of mobile phase & pH 2.8; pH 6.7 & \\
& Organic solvent & Methanol; Acetonitrile \\
& Type of gradient slope & $4 ; 6 ; 8$ & \\
& Quantitative factor & Lower limit & Upper limit \\
& Capillary voltage $(\mathrm{kV})$ & 0.5 & 3.5 \\
& Gradient steepness $(\mathrm{min})$ & 1.5 & 3.5 \\
& Flow rate $(\mathrm{mL} / \mathrm{min})$ & 0.4 & 0.6 \\
CCF-design & Capillary voltage $(\mathrm{kV})$ & 0.4 & 2.0 \\
& Cone voltage $(\mathrm{V})$ & 20 & 35 \\
& Flow rate $(\mathrm{mL} / \mathrm{min})$ & 0.35 & 0.45 \\
\hline
\end{tabular}

$\mathrm{CCF}$, central composite face design.

a Slope 4 is concave downwards; slope 6 is linear; slope 8 is concave upwards.

$2 \mathrm{mM}$ ammonium acetate ( $\mathrm{pH}$ 6.7) and mobile phase B was either methanol $(\mathrm{MeOH})$ or acetonitrile $(\mathrm{ACN})$. The gradient elution program was designed as follows: $0-1.0 \mathrm{~min} 0.5 \% \mathrm{~B} ; 1.5,2.5$ or $3.5 \mathrm{~min}$, respectively, to $20 \% \mathrm{~B} ; 2.5$, 3.5 or $4.5-5.0 \mathrm{~min}$ to $80 \% \mathrm{~B}$; $5.0-5.5 \mathrm{~min}$, hold at $80 \% \mathrm{~B} ; 5.5-5.7 \mathrm{~min}$ to $0.5 \% \mathrm{~B}$; and $5.7-6.5 \mathrm{~min}$, hold at $0.5 \% \mathrm{~B}$. The levels of each experimental factor are presented in Table 2 . The experimental design consisted of 39 experiments, including 3 center point runs performed in 2 different domains, ESI+ and ESI-. The retention time and peak area for each of the purine analytes were studied. A central composite face (CCF) design with a quadratic model was generated to identify the optimal settings for the mass spectrometer at an optimal flow rate for the UPLC for quantification of DHA in human urine. Three factors, capillary voltage, cone voltage and flow rate, were investigated and related to the peak area of DHA, using PLS regression in 12 experiments plus central point replications.

\subsection{Pre-validation of the UPLC-MS/MS assay}

The following parameters were assessed during pre-validation of the UPLC-MS/MS assay: selectivity, concentration function, limit of detection (LOD) and lower limit of quantification (LLOQ), intraand inter-day assay precision and accuracy, auto-sampler stability, carryover, dilution integrity and matrix effect of the corresponding matrix. The selectivity was assessed by analyzing blank urine samples, with and without internal standard, from six healthy individuals, as well as blank urine samples spiked with DHA at the LLOQ concentration level $(100 \mathrm{ng} / \mathrm{mL})$. The concentration function of the method was evaluated at concentrations ranging from 100 to $5000 \mathrm{ng} / \mathrm{mL}$ for DHA. Calibration curves were generated by plotting the corresponding peak area ratio under the specific MRM chromatogram for the analyte or internal standard versus the corresponding analyte concentrations using weighted $(1 / x)$ least squares quadratic regression. The LOD and LLOQ were evaluated by replicate analysis $(n=6)$ and defined as the lowest concentrations that gave a signal-to-noise $(\mathrm{S} / \mathrm{N})$ ratio of at least 3-fold and 20 -fold, respectively. Intra- and inter-assay precision (the relative standard deviation, RSD) and accuracy (the relative error) were determined by replicate analysis $(n=6)$ of the LLOQ and QC samples, conducted over three different days. The stability of the processed samples, which were kept in the autosampler at $22^{\circ} \mathrm{C}$ for at least $18 \mathrm{~h}$, was tested by replicate analysis $(n=6)$ of each QC concentration level and compared to QC samples measured immediately after sample preparation. Carryover in the UPLC-MS/MS system was tested by analyzing a blank urine sample spiked with internal standard, following analysis of urine samples at the upper limit of quantification. Matrix effect was assessed by comparing the peak area for DHA in spiked blank urine samples from six healthy individuals with MQ water spiked with DHA. In both cases, the samples were diluted

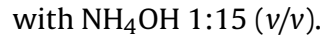

\subsection{Measurement of DHA in urine samples from patients with APRT deficiency}

This part of the study was approved by the National Bioethics Committee of Iceland (NBC 09-072) and the Icelandic Data Protection Authority. Informed consent was obtained from all living participants. Twenty-four hour urine samples were collected from 3 adult patients with APRT deficiency, who were not receiving xanthine dehydrogenase inhibitor (allopurinol or febuxostat) treatment and 6 healthy individuals. All 3 patients had an estimated glomerular filtration rate $(\mathrm{eGFR}) \geq 60 \mathrm{~mL} / \mathrm{min} / 1.73 \mathrm{~m}^{2}$. Within $2 \mathrm{~h}$ of arrival at the laboratory, the $24 \mathrm{~h}$ collection bottle was inverted $3,13,18$ and 28 times and subsequently aliquoted. After the last inversion, the remaining urine was aliquoted and stored for up to $72 \mathrm{~h}$ at $20^{\circ} \mathrm{C}, 4^{\circ} \mathrm{C}$ and at $-20^{\circ} \mathrm{C}(\mathrm{pH}$ 8.6). Finally, the $\mathrm{pH}$ of the urine samples, which were kept at room temperature for $72 \mathrm{~h}$, was raised to $\mathrm{pH} 10$ by adding $25 \% \mathrm{NH}_{4} \mathrm{OH}$ during continuous stirring with a magnetic mixer. Prior to UPLC-MS/MS analysis, urine samples were diluted $1: 15(v / v)$ with $10 \mathrm{mM} \mathrm{NH}_{4} \mathrm{OH}$. Then, $50 \mu \mathrm{L}$ of the diluted samples were pipetted into a 96 -well plate, followed by addition of $100 \mu \mathrm{L}$ of $10 \mathrm{mM} \mathrm{NH}_{4} \mathrm{OH}$ and subsequently $50 \mu \mathrm{L}$ of the internal standard working solution. All samples were subsequently mixed in the plate for $3 \mathrm{~min}$ and centrifuged at $3100 \mathrm{rpm}$ for $10 \mathrm{~min}$ at $4{ }^{\circ} \mathrm{C}$ before injection into the UPLC-MS/MS system.

\subsection{Data processing}

All data were acquired using the MassLynx 4.1 software program and processed with TargetLynx ${ }^{\mathrm{TM}}$ Application Manager (Waters Corp., Milford, MA, USA). GraphPad prism (GraphPad software Inc, La Jolla, LA, USA) was used for statistical analysis, including a one- 


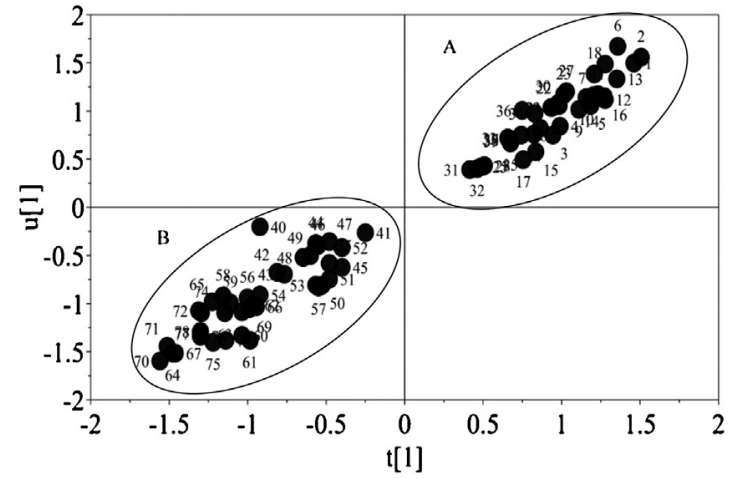

Fig. 1. Partial least squares (PLS) scores plot for area of 2,8-dihydroxyadenine, adenine, adenosine, 2-deoxyadenosine, hypoxanthine, inosine, 2-deoxyinosine and uric acid. Positive ionization mode (A) and negative ionization mode (B) are shown. u [1] is the $\mathrm{Y}$ scores of component 1 and $\mathrm{t}[1]$ is the $\mathrm{X}$ scores of PLS component 1.

way ANOVA with Tukey Multiple Comparison test. Data shown represent the results of 6 separate analyses.

All multivariate experimental design data analyses and calculations were carried out using the MODDE Pro 11 software (Data Analytics Solutions, MKS Instruments AB, Umea, Sweden). This included generation of response surface models, analysis of regression coefficients at $95 \%$ confidence intervals and prediction of optimum conditions of the experimental design, based on criteria for the highest DHA peak area at the minimum retention time. All responses were centered and scaled to unit variance and log scale transformation was applied for the peak area of all analytes.

\section{Results and discussion}

\subsection{Chemometric optimization of the UPLC-MS/MS assay}

D-optimal design with an interaction model was selected for screening of important experimental variables and their appropriate ranges for the UPLC-MS/MS assay, as this model allows for simultaneous evaluation of both multilevel qualitative factors and quantitative factors. The retention time of all purines studied and the peak area of DHA were selected as responses, since our primary goal was to develop a sensitive and accurate method for quantification of DHA in human urine samples, without any interference from early eluting matrix components or other purines. PLS regression analyses of the peak area of all purines studied, both in ESI+ and ESI- modes, revealed two distinguishable groups (Fig. 1). Group A, corresponding to all experimental values in the $\mathrm{ESI}+$ mode, demonstrated a much higher response (peak area) compared with group $B$, which represented experiments carried out in ESI- mode. Therefore, the ESI+ mode was utilized for the remainder of the work as it resulted in much higher sensitivity for each purine. The fraction of variance $\left(\mathrm{R}^{2}\right)$, explained by the PLS regression analysis of the responses in the ESI+ mode, was $>91 \%$ for all responses with an acceptable prediction ability of the model $\left(\mathrm{Q}^{2}>80 \%\right)$. The plot from the PLS regression modeling of the purines showed that flow rate, $\mathrm{pH}$ and the type of organic modifier of the mobile phase had the most significant effect on retention time, with a low flow rate, $\mathrm{pH}$ of 6.7 and methanol as mobile phase B resulting in a higher retention time (data not shown). Adequate separation of the purines was achieved for all conditions studied during the experimental screening in the ESI+ mode as is illustrated in Fig. 2. This is important as spontaneous fragmentation of adenosine and 2-deoxyadenosine into the same ion fragment as adenine
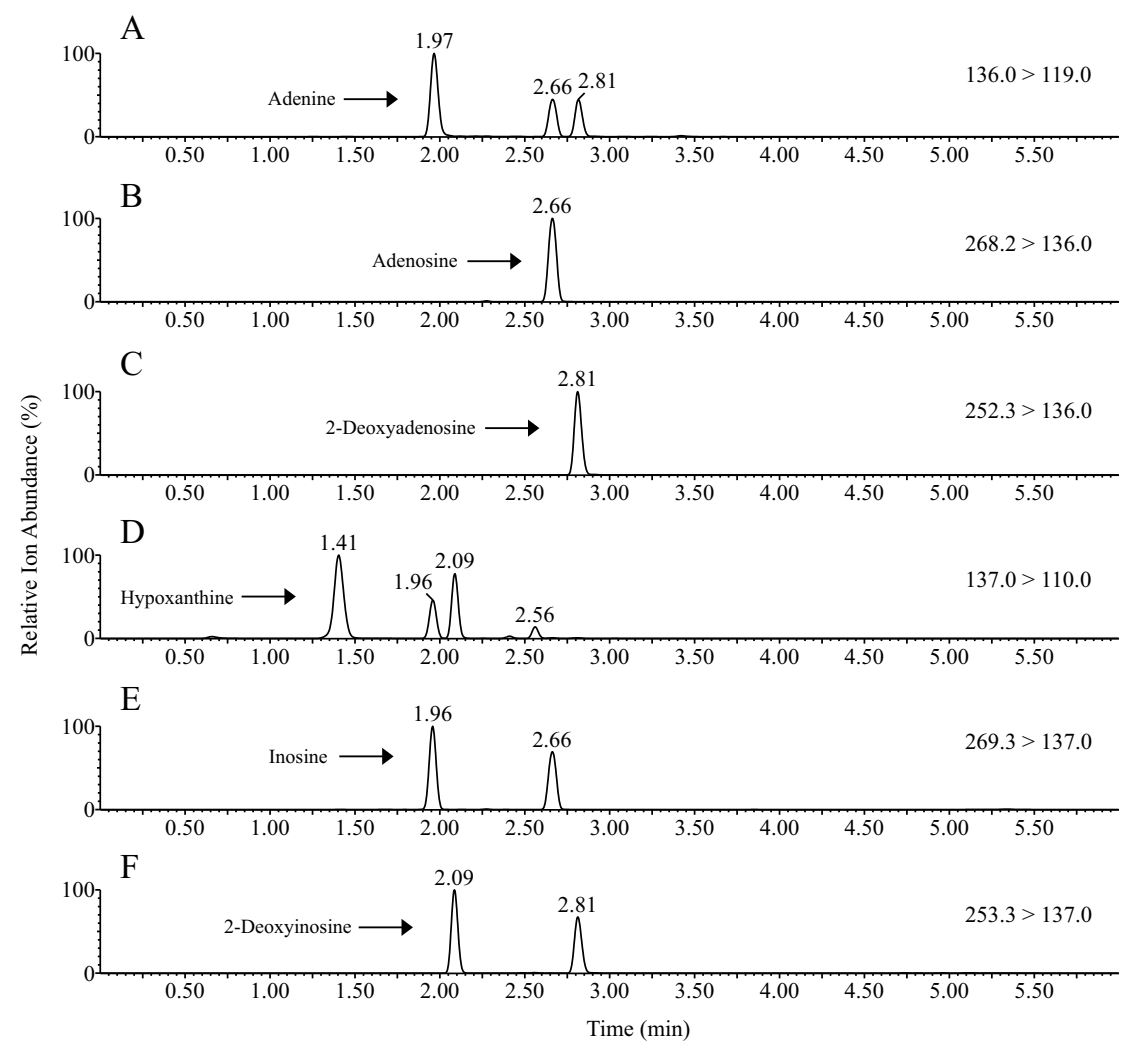

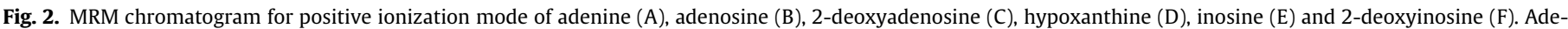

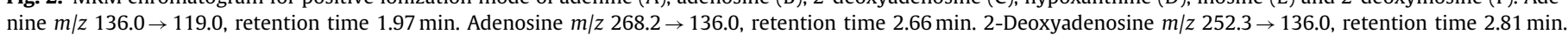

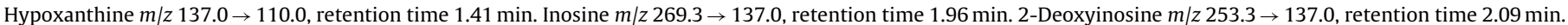




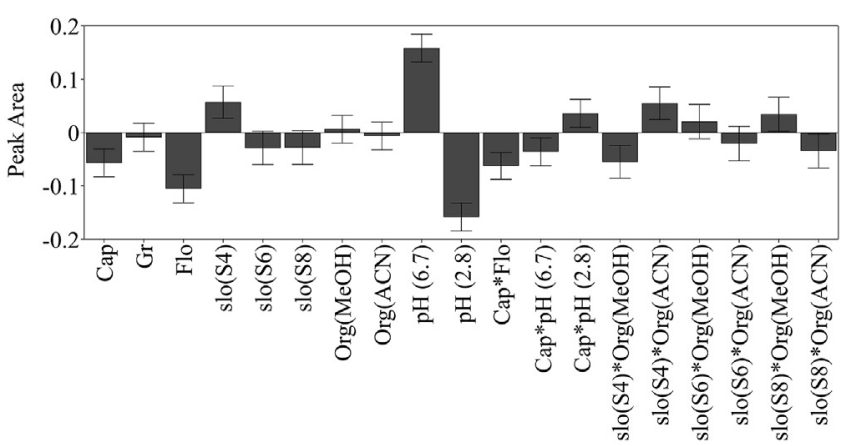

Fig. 3. Regression coefficients plot scaled and centered for the peak area of 2,8dihydroxyadenine. X-axis displays experimental factors and factor interactions that have significant effect on the peak area of 2,8-dihydroxyadenine and y-axis peak area. Error bars represent the $95 \%$ confidence interval. Cap, capillary voltage $(\mathrm{kV})$; Gr, gradient steepness ( $\mathrm{min}$ ); Flo, flow rate $(\mathrm{ml} / \mathrm{min})$; Slo, slope; Org, organic mobile phase; $\mathrm{MeOH}$, methanol; $\mathrm{ACN}$, acetonitrile.
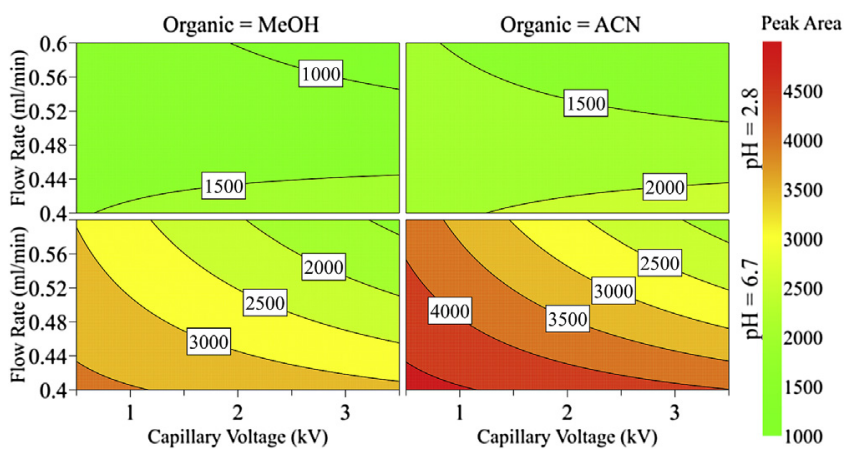

Fig. 4. Counterplot for the peak area of 2,8-dihydroxyadenine, according to flow rate, capillary voltage, $\mathrm{pH}$ of the mobile phase and the organic modifiers, methanol $(\mathrm{MeOH})$ and acetonitrile $(\mathrm{ACN})$.

and of inosine and 2-deoxyinosine into the same ion fragment as hypoxanthine may occur.

The regression coefficient plot of the scaled and centered peak area of DHA showed that capillary voltage, flow rate and mobile phase $\mathrm{A}$ at $\mathrm{pH} 2.8$ had a significant negative effect, while nonlinear gradient (slope 4 ) and mobile phase $\mathrm{A}$ at $\mathrm{pH} 6.7$ had a significant positive effect on the peak area (Fig. 3). Several interaction effects between capillary voltage and flow rate, capillary voltage and $\mathrm{pH}$ of the mobile phase, and type of gradient slope and organic modifier in the mobile phase, were significant so these variables cannot be independently controlled to obtain maximum sensitivity. This is further illustrated in Fig. 4, showing a counterplot of the DHA peak area as a function of flow rate and capillary voltage at different mobile phase conditions. Mobile phase $\mathrm{A}$ at $\mathrm{pH} 6.7$, as opposed to $\mathrm{pH}$ 2.8 , yielded a much higher peak area of DHA and the same was true for acetonitrile as an organic modifier in mobile phase B. Moreover, the sensitivity of the method could be improved by the decreasing capillary voltage and flow rate.

The results of the screening studies were used to select significant variables for final optimization of the quantification method. A CCF design was chosen and correlated to the sensitivity of the analyte employing PLS regression. The experimental domain was redefined and the experimental factors studied included capillary voltage, cone voltage and flow rate (Table 2). A nonlinear gradient slope was used for mobile phase $\mathrm{A}(\mathrm{pH}$ 6.7) and mobile phase $B$ (acetonitrile) with the gradient steepness set at $1.5 \mathrm{~min}$. A response surface model was fitted utilizing PLS regression analysis of the peak area of DHA. Two PLS components were significant, the explained variance $>96 \%$ and the acceptable predictability of the model $\left(Q^{2}>85 \%\right)$. The optimal experimental conditions observed and subsequently used for the analysis of urine samples were: mobile phase $\mathrm{A}$ at $\mathrm{pH}$ 6.7; acetonitrile as mobile phase $\mathrm{B}$; flow rate of $0.35 \mathrm{~mL} / \mathrm{min}$ with a nonlinear gradient slope, raising the concentration of mobile phase B from 0.5 to $20 \%$ in $1.5 \mathrm{~min}$; capillary voltage of $0.4 \mathrm{kV}$; and cone voltage for DHA set at $35 \mathrm{~V}$. The final experimental conditions selected for the quantification method are summarized in Table 3.

\subsection{Analytical performance of the optimized UPLC-MS/MS assay}

We report for the first time an absolute quantification of DHA in human urine samples by UPLC-MS/MS, using the isotopically labeled reference compound, DHA-2- ${ }^{13} \mathrm{C}-1,3-{ }^{15} \mathrm{~N}_{2}$, as an internal standard. The results from the pre-validation study of the assay showed acceptable selectivity without any interfering peaks in the human urine samples from the 6 individuals tested. There were no interfering peaks detected in the blank matrix at the same retention time as for DHA, as demonstrated by the MRM chromatogram of blank urine from a healthy individual (Fig. 5a) compared with the blank matrix spiked with DHA at LLOQ concentration (Fig. 5b). The results also indicate that urine from healthy individuals does not contain significant endogenous levels of DHA, as DHA was not detected in any of the six urine matrixes analyzed (data not shown). The back calculated concentration of all calibration standards, including the LLOQ, were within acceptable limits of $\pm 15 \%$ of the nominal value (data only shown for LLOQ), in the concentration range of 100 to $5000 \mathrm{ng} / \mathrm{mL}$ (Table 4). The limit of detection for DHA was $20 \mathrm{ng} / \mathrm{mL}$ and the LLOQ of the method was set at $100 \mathrm{ng} / \mathrm{mL}$. The analytical performance of the assay was tested for LLOQ and QC samples using blank matrix spiked with DHA at 3 different concentrations, 300,800 and $2000 \mathrm{ng} / \mathrm{mL}$, on three different days. Intraday coefficients of variation (CVs) were 4.5-5.7\% with accuracy of $-2.0-8.5 \%$ for all QC samples. Intraday CVs for LLOQ were $8.3 \%$ with accuracy $3.3 \%$. The interday accuracy and precision CVs for QC samples and LLOQ were well within the $\pm 15 \%$ limits (Table 4). The processed samples $(n=6)$ were stable up to $18 \mathrm{~h}$ at $22{ }^{\circ} \mathrm{C}$ in the autosampler with CV for all QC samples $<6 \%$ and with a mean bias of the back calculated concentration $<11 \%$. To evaluate carryover, a blank urine sample was injected immediately following analysis of the highest DHA standard at $5000 \mathrm{ng} / \mathrm{mL}$ but no DHA peak was detected. Dilution integrity was evaluated by spiking DHA into a blank urine sample at a concentration of $10.000 \mathrm{ng} / \mathrm{mL}$ and diluting the sample with $10 \mathrm{mM} \mathrm{NH}_{4} \mathrm{OH}$ down to the range of the concentration curve. The DHA concentration of the diluted samples $(n=3)$ was within $\pm 15 \%$ of nominal values, demonstrating good sample integrity. The matrix effect was evaluated by comparing the response for DHA spiked at the same concentration in blank urine and in neat solution. The response for DHA was the same in blank urine samples from 6 different biological sources as in the neat solution (data not shown), indicating no significant matrix effect.

Hartmann et al. [18] reported relative quantification of urinary DHA and other key purine metabolites in a total analysis time of $20 \mathrm{~min}$, whereas the analytical run time was only $6.5 \mathrm{~min}$ with our method. The limit of detection for DHA was much higher than in our assay, $167 \mathrm{ng} / \mathrm{mL}$ vs. $20 \mathrm{ng} / \mathrm{mL}$ and the interday CV for DHA was quite high or 25\% [18]. Urinary DHA has also been measured using HPLC coupled to a multichannel ultraviolet detector, but this method required computer-aided data analysis and a $30 \mathrm{~min}$ analytical run time [13]. In addition, CE has been used for relative quantification of DHA in urine samples with a markedly shorter analytical run time than can be achieved with the HPLC-based methods [14-17]. However, reproducibility has been a challenge when CE methods are used in conjunction with UV detection as the peak identification is based on detection time which can vary 
Table 3

Experimental conditions of the UPLC-MS/MS assay for quantification of DHA.

\begin{tabular}{|c|c|c|c|}
\hline Instrument/conditions & \multicolumn{3}{|l|}{ Details } \\
\hline UPLC-MS/MS & \multicolumn{3}{|c|}{ Waters ACQUITY - Quattro Premier ${ }^{\mathrm{TM}} \mathrm{XE}$} \\
\hline Analytical column & \multicolumn{3}{|c|}{ Waters Acquity HSS T3 $2,1 \times 100 \mathrm{~mm}, 1.8 \mu \mathrm{m}$} \\
\hline Column temperature & \multicolumn{3}{|l|}{$35^{\circ} \mathrm{C}$} \\
\hline Autosampler temperature & \multicolumn{3}{|l|}{$22{ }^{\circ} \mathrm{C}$} \\
\hline Flow rate & \multicolumn{3}{|l|}{$0.35 \mathrm{~mL} / \mathrm{min}$} \\
\hline Mobile phase & \multicolumn{3}{|c|}{ A: 2 mM Ammonium acetate at $\mathrm{pH} 6.7$; $\mathrm{B}$ : Acetonitrile } \\
\hline \multirow[t]{8}{*}{ Gradient slope } & Time (min) & $\% A$ & $\% \mathrm{~B}$ \\
\hline & 0.0 & 99.5 & 0.50 \\
\hline & 1.0 & 99.5 & 0.50 \\
\hline & 2.5 & 80.0 & 20.0 \\
\hline & 5.0 & 20.0 & 80.0 \\
\hline & 5.5 & 20.0 & 80.0 \\
\hline & 5.7 & 99.5 & 0.50 \\
\hline & 6.5 & 99.5 & 0.50 \\
\hline Gradient slope & \multicolumn{3}{|c|}{ Concave downwards } \\
\hline Sample injection & \multicolumn{3}{|c|}{$5 \mu \mathrm{L}$ of urine sample diluted $1: 15(v / v)$ with $10 \mathrm{mM} \mathrm{NH}_{4} \mathrm{OH}$} \\
\hline Ionization mode & \multicolumn{3}{|c|}{ Positive electrospray ionization } \\
\hline Capillary voltage & \multicolumn{3}{|c|}{$0.4 \mathrm{kV}$} \\
\hline Cone voltage & \multicolumn{3}{|l|}{$35 \mathrm{~V}$} \\
\hline
\end{tabular}

a.

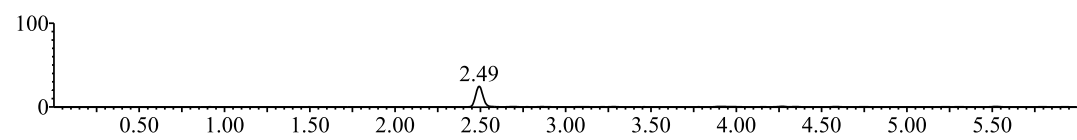

b.
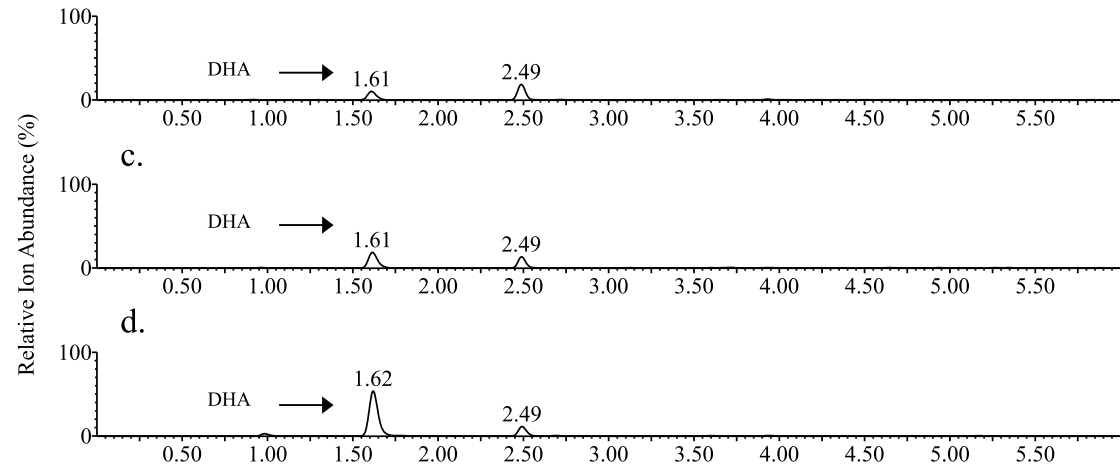

e.

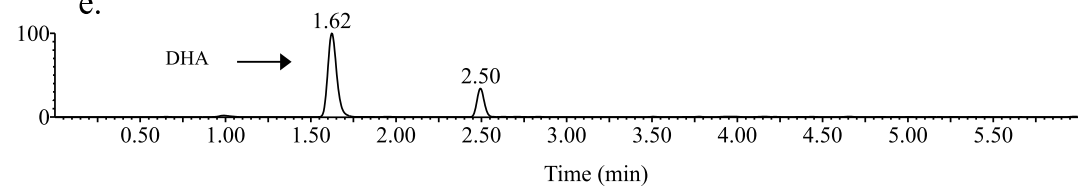

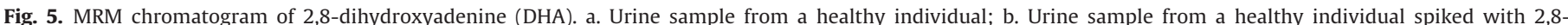
dihydroxyadenine at a concentration of $100 \mathrm{ng} / \mathrm{mL}$; c-e. Urine samples from patients with APRT deficiency.

Table 4

Intra-assay and inter-assay accuracy and precision of DHA measurement in urine samples.

\begin{tabular}{|c|c|c|c|c|c|}
\hline \multirow[t]{2}{*}{ QC Level } & \multirow[t]{2}{*}{ Concentration (ng/mL) } & \multicolumn{2}{|c|}{ Intraday $(n=6)$} & \multicolumn{2}{|c|}{ Interday $(n=3)$} \\
\hline & & $\% \mathrm{CV}^{\mathrm{a}}$ & \%Bias ${ }^{\mathrm{b}}$ & $\% \mathrm{CV}^{\mathrm{a}}$ & \%Bias ${ }^{\mathrm{b}}$ \\
\hline LLOQ & 100 & 8.3 & 3.3 & 7.8 & 0.5 \\
\hline QC-low & 300 & 5.7 & -2.0 & 5.4 & -4.6 \\
\hline QC-medium & 800 & 4.7 & 6.5 & 7.4 & 3.1 \\
\hline QC-high & 2000 & 4.5 & 8.5 & 3.4 & 4.4 \\
\hline
\end{tabular}

Calibration range $100-5000 \mathrm{ng} / \mathrm{mL}, \mathrm{R}^{2}=0.9989$ with weighing factor $1 / \mathrm{X}$.

$\mathrm{QC}$, quality control; LLOQ lower limit of quantification; CV, coefficient of variation.

a $\% \mathrm{RSD}=($ standard deviation $/$ mean $) \times 100$.

b $\%$ Bias $=($ mean calculated concentration - nominal concentration $) /($ nominal concentration $) \times 100$.

greatly amongst different matrices. None of the previously reported techniques for urinary DHA determination has been fully developed for clinical application. In fact, only relative quantification of DHA has been accomplished due to lack of isotopically labeled reference standards.

\subsection{Measurement of DHA concentration in urine samples from patients with APRT deficiency}

Due to the poor solubility of DHA, storage and handling of urine specimens from patients with APRT deficiency may influence the 
a.

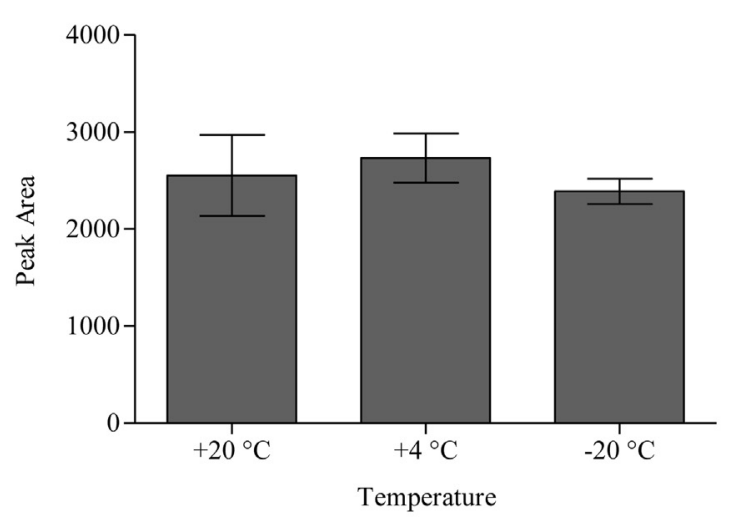

b.

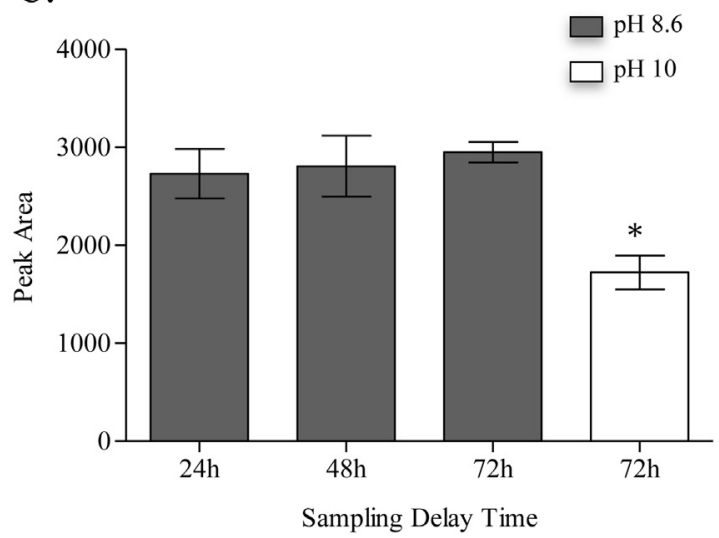

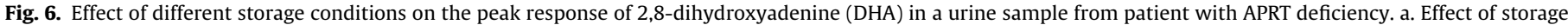
temperature on the peak area of DHA. b. Effect of storage time on the peak area of DHA at pH 8.6 and 10 . *Indicates a significant decrease of the peak area (P<0.001).

measurement of the DHA concentration. Since $24 \mathrm{~h}$ urine collection is almost exclusively conducted by patients at home, we investigated the effect of storage temperature on the measurement of DHA in urine specimens obtained from 3 patients. No significant difference was observed in the peak area of DHA at $+20^{\circ} \mathrm{C},-4^{\circ} \mathrm{C}$ or at $-20^{\circ} \mathrm{C}$ for up to at least $72 \mathrm{~h}$ at $\mathrm{pH} 8.6$, indicating no significant effect of storage temperature on the DHA signal response (Fig. 6a). Accordingly, urine samples may be kept at room temperature up to $72 \mathrm{~h}$ prior to analysis without affecting the results. Raising the $\mathrm{pH}$ of the urine samples to $\mathrm{pH} 8.6$ improved the response of DHA, but additional increase of the $\mathrm{pH}$ to 10 with $25 \% \mathrm{NH}_{4} \mathrm{OH}$ resulted in a lower response (Fig. 6b). These results are consistent with those reported by Hartmann et al. [18], who observed no change in urinary DHA concentration at $\mathrm{pH}$ values ranging from 3 to 9 . Although Peck et al. [30] also reported that the solubility of DHA can be increased by raising the $\mathrm{pH}$ beyond baseline values, this resulted in very unstable solutions. Increased sample mixing did not have significant effect on the peak area of DHA (data not shown) and, therefore, it was decided to invert the collection bottle only 3 times during further experiments.

Twenty-four hour urine samples from 3 patients with APRT deficiency, who were not receiving pharmacological treatment and from 6 healthy individuals were analyzed using the UPLC-MS/MS assay. MRM chromatogram illustrated a peak corresponding to DHA in the patients' samples, which was not detected in the sample from the healthy individuals (Fig. 5a, c, d and e). An unidentified peak was observed in the MRM chromatogram of all the urine samples from the patients and the control individuals (data shown for 1 healthy individual) that was well separated from the DHA peak and did not interfere with the quantification of DHA. The clinical applicability of the assay was demonstrated by determining the concentration of DHA in $24 \mathrm{~h}$ urine samples from patients with APRT deficiency, diluted $1: 15(\mathrm{v} / \mathrm{v})$ with $10 \mathrm{mM} \mathrm{NH} \mathrm{NH}_{4} \mathrm{OH}$. The urinary DHA concentration in the three patients was 3021, 5860 and $10563 \mathrm{ng} / \mathrm{mL}$ and the $24 \mathrm{~h}$ urinary DHA excretion 816, 1327 and $1649 \mathrm{mg}$, respectively, suggesting a highly variable excretion rate between patients (Fig. 7).

\section{Conclusions}

We have successfully developed a rapid and robust UPLC-MS/MS assay with minimal sample preparation for absolute quantification of DHA in urine, utilizing isotopically labeled DHA as an internal standard. The chemometric approach (DOE), for optimization of the UPLC-MS/MS method was demonstrated to be highly effective, requiring only a fraction of the number of

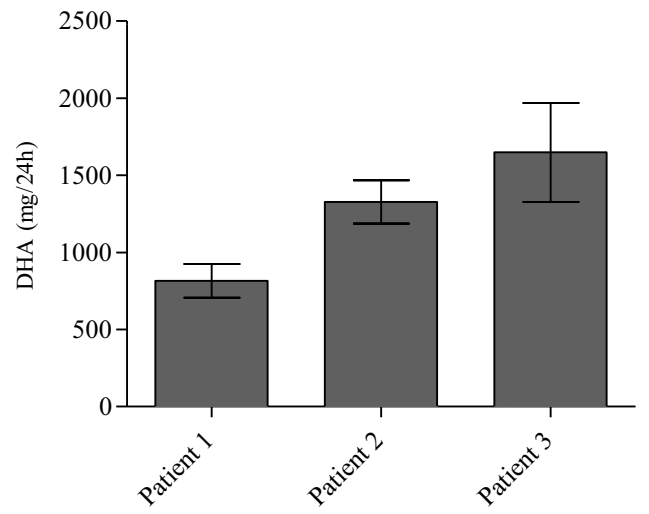

Fig. 7. 24 h urinary 2,8-dihydroxyadenine (DHA) excretion in 3 patients with APRT deficiency who were not receiving treatment with a xanthine dehydrogenase inhibitor. Patient 1, 2 and 3 correspond to c, d and e in Fig. 5, respectively. Data represents mean values and SD of six measurements by the UPLC-MS/MS assay.

experiments that would have been needed when changing only one separate factor at a time.

We believe this UPLC-MS/MS assay will greatly facilitate clinical diagnosis and monitoring of pharmacotherapy in patients with APRT deficiency. Preliminary data from patients with APRT deficiency demonstrate that urinary DHA is easily detected by the assay and that absolute concentration of DHA can be determined in patient's samples at a broad concentration range.

Future work will focus on evaluation of the UPLC-MS/MS urinary assay in individuals with APRT deficiency, aiming for full validation for use in clinical practice.

\section{Acknowledgements}

Part of this work was presented in an abstract form at the American Society of Nephrology Kidney Week in Atlanta, GA, November 2013 and at the American Society for Mass Spectrometry in St. Louis, MO, May 2015. The study was supported by the Rare Kidney Stone Consortium (U54DK083908), a part of the Rare Diseases Clinical Research Network (RDCRN), an initiative of the Office of Rare Diseases Research (ORDR), National Center for Advancing Translational Sciences (NCATS). This consortium is funded through a collaboration between NCATS, and the National Institute of Diabetes and Digestive and Kidney Diseases (NIDDK). The authors would like to thank L. Fairbanks, Purine Research Laboratory, St Thomas' Hospital, London, UK, who kindly provided our research 
team with a sample of 2,8-dihydroxyadenine (manufactured by Sigma-Aldrich, Germany, but no longer commercially available) for the initial assay development.

\section{References}

[1] H.A. Simmonds, K.J. Van Acler, J.S. Cameron, W. Snedden, The identification of 2,8-dihydroxyadenine, a new component of urinary stones, Biochem. J. 157 (1976) 485-487.

[2] H. Takeuchi, Y. Kaneko, J. Fujita, O. Yoshid, A case of compound heterozygote for adenine phosphoribosyltransferase deficiency (APRT*J/APRT*Q0) leading to 2,8-dihydroxyadenine urolithiasis: review of the reported cases with 2,8-dihydroxyadenine stones in Japan, J. Urol. 149 (1993) 824-826.

[3] A. Sahota, J. Tischfield, N. Kamatani, H.A. Simmonds, Adenine phosphoribosyltransferase deficiency and 2,8-dihydroxyadenine lithiasis, in: C.R. Scriver, A.L. Beaudet, W.S. Sly, D. Valle, B. Volgelstein, B. Childs (Eds.), The Metabolic and Molecular Bases of Inherited Disease, eighth ed., McGraw-Hill, New York, 2001, pp. 2571-2584.

[4] V. Edvardsson, R. Palsson, I. Olafsson, G. Hjaltadottir, T. Laxdal, Clinical features and genotype of adenine phosphoribosyltransferase deficiency in Iceland, Am. J. Kidney Dis. 38 (2001) 473-480.

[5] G. Bollée, C. Dollinger, L. Boutaud, D. Guillemot, A. Bensman, J. Harambat, P. Deteix, M. Daudon, B. Knebelmann, I. Ceballos-Picot, Phenotype and genotype characterization of adenine phosphoribosyltransferase deficiency, J. Am. Soc. Nephrol. 21 (2010) 679-688.

[6] J. Harambat, G. Bollée, M. Daudon, I. Ceballos-Picot, A. Bensman, APRT study group, adenine phosphoribosyltransferase deficiency in children, Pediatr. Nephrol. 27 (2012) 571-579.

[7] V.O. Edvardsson, D.S. Goldfarb, J.C. Lieske, L. Beara-Lasic, F. Anglani, D.S. Milliner, R. Palsson, Hereditary causes of kidney stones and chronic kidney disease, Pediatr. Nephrol. 28 (2013) 1923-1942.

[8] H.L. Runolfsdottir, R. Palsson, I.M. Agustdottir, O.S. Indridason, V.O. Edvardsson, Kidney disease in adenine phosphoribosyltransferase deficiency, Am. J. Kidney Dis. 67 (2015) 431-438.

[9] G. Bollée, J. Harambat, A. Bensman, B. Knebelmann, M. Daudon, I. Ceballos-Picot, Adenine phosphoribosyltransferase deficiency, Clin. J. Am. Soc. Nephrol. 7 (2012) 1521-1527.

[10] H.A. Simmonds, C.F. Potter, A. Sahota, J.S. Cameron, G.A. Rose, T.M. Barratt, D.I. Williams, D.G. Arkell, K.J. Van Acker, Adenine phosphoribosyltransferase deficiency presenting with supposed uric acid stones: pitfall of diagnosis, J. R. Soc. Med. 71 (1978) 791-795.

[11] M.J. Cassidy, T. McCulloch, L.D. Fairbanks, H.A. Simmonds, Diagnosis of adenine phosphoribosyltransferase deficiency as the underlying cause of renal failure in renal transplant, Nephrol. Dial. Transplant. 19 (2004) 736-738

[12] V.O. Edvardsson, R. Palsson, A. Sahota, Adenine phosphoribosyltransferase deficiency, R.A. Pagron, M.P. Adam, H.H. Ardinger, S.E. Wallace, A. Amemiya, L.J.H. Bean, T.D. Bird, N. Ledbetter, H.C. Mefford, R.J.H. Smith, K. Stephens, GeneReviews ${ }^{\circledR}$ [Internet], University of Washington, Seattle, 1993-2016 30.08.12 (updated 18.06.15), http://www.genetests.org, (accessed 15.02.16).
[13] T. Kojima, T. Nishina, M. Kitamura, N. Kamatani, K. Nishloka, Liquid chromatography with multichannel ultraviolet detection used for studying disorders of purine metabolism, Clin. Chem. 33 (1987) 2052-2056.

[14] J. Sevcik, T. Adam, H. Mazacova, A fast and simple screening method for detection of 2,8-dihydroxyadenine urolithiasis by capillary zone electrophoresis, Clin. Chim. Acta 245 (1996) 85-92.

[15] T. Wessel, C. Lanvers, S. Fruend, G. Hempel, Determination of purines including 2,8-dihydroxyadenine in urine using capillary electrophoresis, J. Chromatogr. A 894 (2000) 157-164

[16] T. Adam, D. Friedecky, L.D. Fairbanks, J. Sevcik, P. Bartak, Capillary electrophoresis for detection of inherited disorders of purine and pyrimidine metabolism, Clin. Chem. 45 (1999) 2086-2093.

[17] T. Adam, P. Lochman, D. Friedecky, Screening method for inherited disorders of purine and pyrimidine metabolism by capillary electrophoresis with reversed electroosmotic flow, J. Chromatogr. B 767 (2002) 333-340.

[18] S. Hartmann, J.G. Okun, C. Schmidt, C.D. Langhans, S.F. Garbade, P. Burgard, D. Haas, J.O. Sass, W.L. Nyhan, G.F. Hoffmann, Comprehensive detection of disorders of purine and pyrimidine metabolism by HPLC with electrospray ionization tandem mass spectrometry, Clin. Chem. 52 (2006) 1127-1137.

[19] K.C. Dooley, Tandem mass spectrometry in the clinical chemistry laboratory, Clin. Biochem. 36 (2003) 471-481.

[20] M. Himmelsbach, 10 years of MS instrumental developments -impact on LC-MS/MS in clinical chemistry, J. Chromatogr. B Anal. Technol. Biomed. Life Sci. 883-884 (2012) 3-17.

[21] J.M. van den Ouweland, I.P. Kema, The role of liquid chromatography-tandem mass spectrometry in the clinical laboratory, J. Chromatogr. B Anal. Technol. Biomed. Life Sci. 883-884 (2012) 18-32.

[22] G.E.P. Box, W.G. Hunter, J.S. Hunter, Statistics for Experimenters: an Introduction to Design Data Analysis and Model Building, John Wiley and Sons Inc, New York, 1978

[23] L. Stahle, S. Wold, Multivariate data analysis and experimental design in biomedical research, Prog. Med. Chem. 25 (1988) 291-338.

[24] D.B. Hibbert, Experimental design in chromatography: a tutorial review, J. Chromatogr. B Anal. Technol. Biomed. Life Sci. 910 (2012) 2-13.

[25] M. Thorsteinsdottir, B.B. SigurĐsson, G. Bragason, Determination of pharmacokinetic parameters by HPLC-MS/MS and UPLC-MS/MS, in: M.S. Lee (Ed.), Mass Spectrometry Handbook, John Wiley and Sons, Inc., Hoboken, NJ, 2012, pp. 191-208

[26] Guidance for Industry: Bioanalytical Method Validation, U.S. Department of Health and Human Services, Food and Drug Administration, Center for Drug Evaluation and Research (CDER), Center for Biologics Evaluation and Research (CBER), (2001).

[27] Liquid Chromatography-Mass Spectrometry Methods; Approved Guideline, CLSI document C62-A, Clinical and Laboratory Standards Institute, Wayne PA (2014).

[28] A. Bendich, J.F. Tinker, G.B. Brown, A synthesis of isoguanine labeled with isotopic nitrogen, J. Am. Chem. Soc. 70 (1948) 3109-3113.

[29] F. Liebe, F. Cavalieri, A. Bendich, The ultraviolet absorption spectra of pyrimidines and purines, J. Am. Chem. Soc. 72 (1950) 2587-2594.

[30] C.C. Peck, J. Bailey, G.L. Moore, Enhanced solubility of 2,8 dihydroxyadenine (DOA) in human urine, Transfusion 17 (1977) 383-390. 